\title{
Palladacycle-Catalyzed Regioselective Heck Reaction Using Diaryliodonium Triflates and Aryliodides
}

Lu Lei ${ }^{\dagger}$, Pei-Sen Zou ${ }^{\dagger}$, Zhi-Xin Wang*, Cui Liang, Cheng Hou*, and Dong-Liang Mo*

State Key Laboratory for Chemistry and Molecular Engineering of Medicinal Resources, Collaborative Innovation Center for Guangxi Ethnic Medicine, School of Chemistry and Pharmaceutical Sciences, Guangxi Normal University, 15 Yu Cai Road, Guilin, 541004, China. E-mail: 862991993@qq.com; houcheng@gxnu.edu.cn; moeastlight@mailbox.gxnu.edu.cn

\section{Contents}

1. General Experimental Information $\quad$ S2

$\begin{array}{ll}\text { 2. Optimization of the reaction conditions } & \text { S2 }\end{array}$

3. Synthesis of compounds 3aa-3ba S3

4. Synthesis of compounds 4aa-4ar S11

5. Gram-scale preparation of 3aa and 4aa $\quad$ S20

$\begin{array}{ll}\text { 6. Hg-poisoning experiments for P5 } & \text { S21 }\end{array}$

7. Deuteration experiments and synthesis of compounds D-3ag $\quad$ S22

8. $\quad$ Proposed intermediates detected by HRMS (ESI) S23

$\begin{array}{lll}\text { 9. } & \text { Other alkenes tested and synthesis of compounds } 7 & \text { S26 }\end{array}$

10. DFT calculations for $\mathrm{Pd}(\mathrm{II}) / \mathrm{Pd}(\mathrm{IV})$ and $\mathrm{Pd}(0) / \mathrm{Pd}(\mathrm{II})$ cycles $\quad \mathrm{S} 27$

$\begin{array}{ll}\text { 11. References } & \text { S66 }\end{array}$

12. NMR spectra of compounds 3aa-3ba, 4aa-4ar, D-1a, D-3ag, and $7 \quad$ S68 


\section{General Experimental Information:}

${ }^{1} \mathrm{H}$ NMR and ${ }^{13} \mathrm{C}$ NMR spectra were recorded at ambient temperature using 400 or $500 \mathrm{MHz}$ spectrometers. The data are reported as follows: chemical shift in ppm from internal tetramethylsilane on the $\delta$ scale, multiplicity $(\mathrm{br}=$ broad, $\mathrm{s}=$ singlet, $\mathrm{d}=$ doublet, $\mathrm{t}=$ triplet, $\mathrm{q}=$ quartet, $\mathrm{m}=$ multiplet $)$, coupling constants $(\mathrm{Hz})$, and integration. Structural assignments were made with additional information from gCOSY, gHSQC, and gHMBC experiments. High resolution mass spectra (HRMS) were measured in ESI mode, and the mass analyzer of the HRMS was TOF. Analytical thin layer chromatography was performed on $0.25 \mathrm{~mm}$ extra hard silica gel plates with UV254 fluorescent indicator. Chromatography was performed using with 300-400 mesh silica gel $\left(\mathrm{SiO}_{2}\right)$. Unless otherwise noted, all reagents and solvents were obtained from commercial sources and, where appropriate, purified prior to use. 2,3-dihydrofuran 1a, aryliodides 5a-5r, and allylbenzene $\mathbf{6 a}$ were purchased from

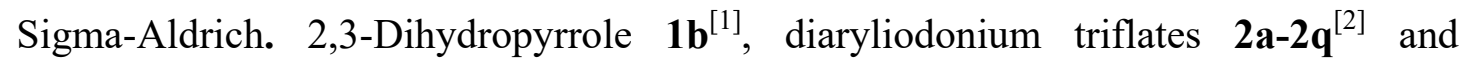
palladacycles $\mathbf{P 1 - P 8 ^ { [ 3 ] }}$ were known compounds and were prepared according to literature methods and their spectral data matched literature values.

\section{Optimization of the reaction conditions}

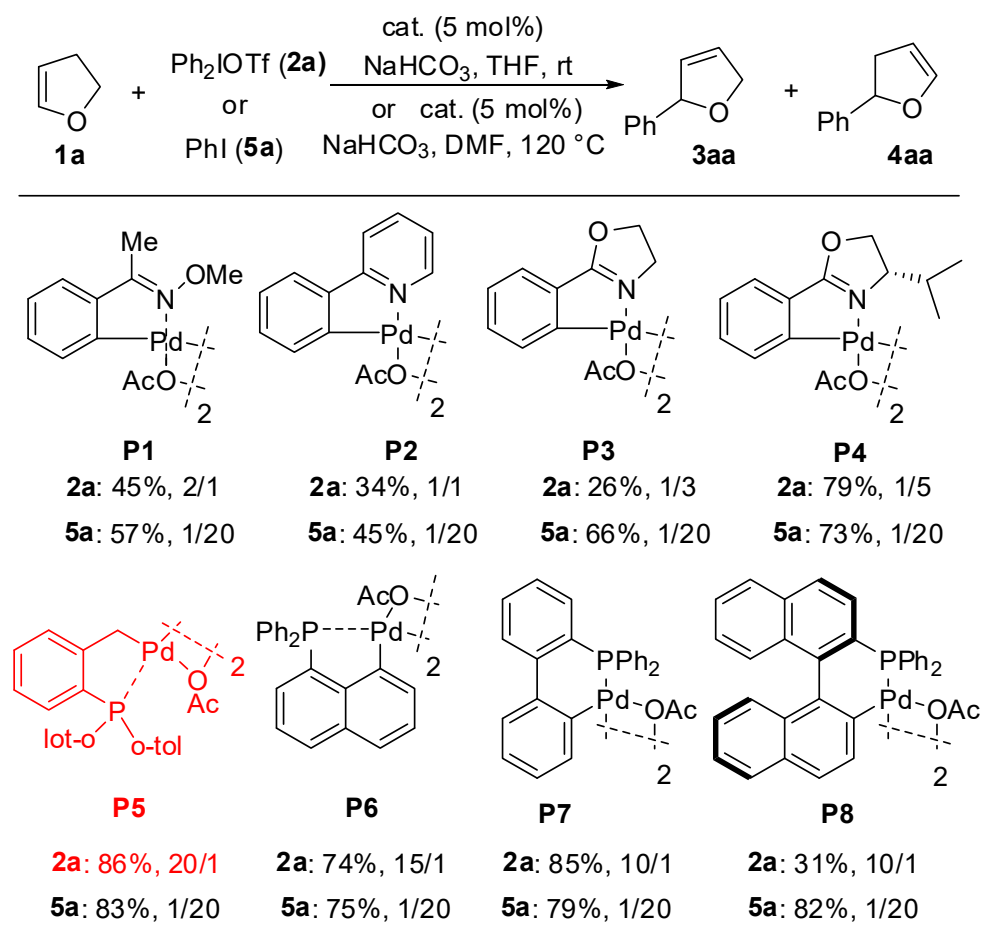




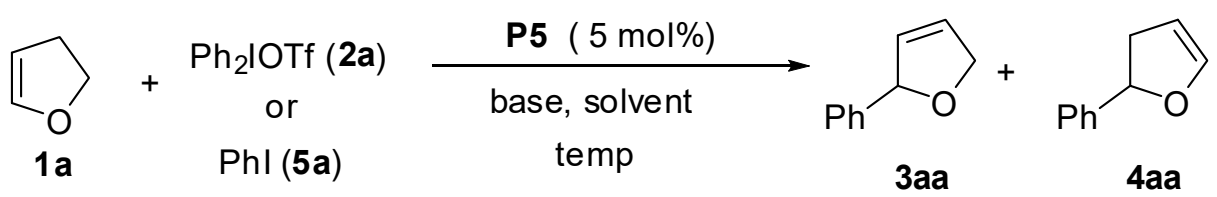

\begin{tabular}{|c|c|c|c|c|}
\hline entry & $2 \mathbf{a} / 5 \mathbf{a}$ & solvent & base & yield $\%{ }^{b}(3 a a: 4 a a)^{c}$ \\
\hline 1 & $2 \mathbf{a}$ & DCE & $\mathrm{NaHCO}_{3}$ & $19(20 / 1)$ \\
\hline 2 & $2 a$ & toluene & $\mathrm{NaHCO}_{3}$ & $73(20 / 1)$ \\
\hline 3 & $2 \mathbf{a}$ & $\mathrm{MeCN}$ & $\mathrm{NaHCO}_{3}$ & $41(15 / 1)$ \\
\hline 4 & $\mathbf{2 a}$ & $\mathrm{MeOH}$ & $\mathrm{NaHCO}_{3}$ & $83(20 / 1)$ \\
\hline 5 & $2 \mathbf{a}$ & $\mathrm{DMF}$ & $\mathrm{NaHCO}_{3}$ & $60(20 / 1)$ \\
\hline 6 & $2 \mathbf{a}$ & $\mathrm{THF}$ & $\mathrm{Cs}_{2} \mathrm{CO}_{3}$ & $74(20 / 1)$ \\
\hline 7 & $2 a$ & THF & $\mathrm{KOH}$ & $53(12 / 1)$ \\
\hline 8 & $2 a$ & THF & pyridine & $<5$ \\
\hline $9^{d}$ & $2 \mathbf{a}$ & THF & $\mathrm{NaHCO}_{3}$ & $83(20 / 1)$ \\
\hline $10^{\mathrm{e}}$ & $2 a$ & THF & $\mathrm{NaHCO}_{3}$ & $63(10 / 1)$ \\
\hline $11^{\mathrm{f}}$ & $2 \mathbf{a}$ & THF & $\mathrm{NaHCO}_{3}$ & $35(5 / 1)$ \\
\hline $12^{\mathrm{g}}$ & $2 \mathbf{a}$ & THF & $\mathrm{NaHCO}_{3}$ & $20(1 / 10)$ \\
\hline $13^{\mathrm{g}}$ & $5 a$ & THF & $\mathrm{NaHCO}_{3}$ & $75(1 / 20)$ \\
\hline $14^{\mathrm{g}}$ & $5 a$ & DMF & $\mathrm{NaHCO}_{3}$ & $81(1 / 20)$ \\
\hline $15^{\mathrm{g}}$ & $5 \mathbf{a}$ & $\mathrm{DMF}$ & $\mathrm{NaHCO}_{3}$ & $<5$ \\
\hline $16^{\mathrm{g}, \mathrm{h}}$ & $5 \mathbf{a}$ & $\mathrm{DMF}$ & $\mathrm{NaHCO}_{3}$ & $83(1 / 20)$ \\
\hline
\end{tabular}

${ }^{a}$ Reaction conditions: 1a $(2.0 \mathrm{mmol}, 4.0$ equiv. $), \mathbf{2 a} / \mathbf{5 a}(0.5 \mathrm{mmol})$, cat. (5 mol\%), base (0.75 mol, 1.5 equiv.), solvent $(3.0 \mathrm{~mL}), 25{ }^{\circ} \mathrm{C}, 18-24 \mathrm{~h} ;{ }^{b}$ isolated yield; ${ }^{\mathrm{c}}$ ratio of 3/4, determined by ${ }^{1} \mathrm{H}$ NMR of the crude mixture; ${ }^{d} \mathrm{Ph}_{2} \mathrm{IBF}_{4}$ instead of $\mathrm{Ph}_{2} \mathrm{IOTf}$; ${ }^{e}$ ran at $50{ }^{\circ} \mathrm{C} ;{ }^{f}$ ran at $80{ }^{\circ} \mathrm{C} ;{ }^{g}$ ran at $120{ }^{\circ} \mathrm{C}, 3-5$ h. ${ }^{h} \mathbf{P 5}(1 \mathrm{~mol} \%)$.

\section{Synthesis of compounds 3aa-3ba}

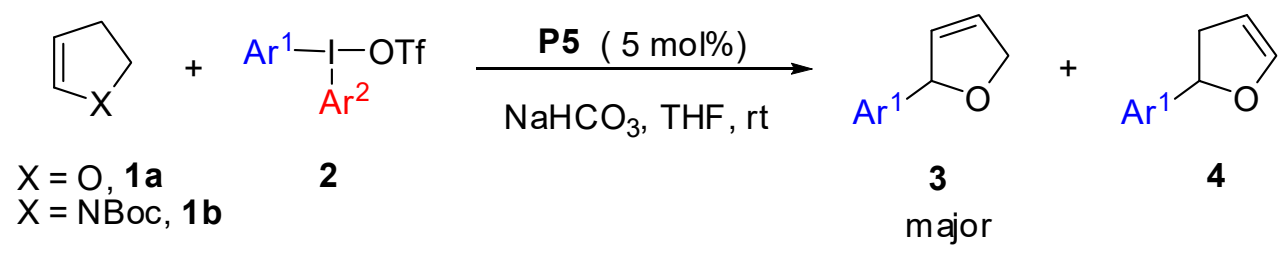

In a $25 \mathrm{~mL}$ Schlenk flask was charged with 2,3-dihydrofuran 1a or 2,3-dihydropyrrole $\mathbf{1 b}$ (2.0 mmol, 4.0 equiv.), diaryliodonium triflates 2 (0.5 mmol), P5 (5 mol \%), $\mathrm{NaHCO}_{3}\left(0.75 \mathrm{mmol}, 1.5\right.$ equiv.), and THF (3 mL) under $\mathrm{N}_{2}$. The 
mixture was stirred at room temperature for 18-24 h until diaryliodonium triflate 2 was completely consumed (monitored by TLC). Then, the solvent was removed under the reduced pressure and the crude product was purified by flash column chromatography (the crude residue was dryloaded with silical gel, ethyl acetate/petroleum ether: $1 / 50$ to $1 / 30$ ) to afford products 3 .

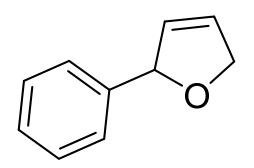

$3 a a$

2-Phenyl-2,5-dihydrofuran (3aa),${ }^{[4]}$ 2,3-Dihydrofuran $\mathbf{1 a}(0.15 \mathrm{~mL}, 2.0 \mathrm{mmol})$ and diaryliodonium triflate $2 \mathrm{a}(215.0 \mathrm{mg}, 0.5 \mathrm{mmol})$ stirring at $25{ }^{\circ} \mathrm{C}$ for $24 \mathrm{~h}$. Purification using medium pressure chromatography (1:30; ethyl acetate: petroleum ether) afforded 3aa. A pale yellow oil, $63.0 \mathrm{mg}, 86 \%$ yield; ${ }^{1} \mathrm{H}$ NMR (500 MHz, $\left.\mathrm{CDCl}_{3}\right): \delta 7.35-7.23(\mathrm{~m}, 5 \mathrm{H}), 6.03-6.01(\mathrm{~m}, 1 \mathrm{H}), 5.89-5.87(\mathrm{~m}, 1 \mathrm{H}), 5.79-5.78(\mathrm{~m}$, $1 \mathrm{H}), 4.88-4.85(\mathrm{~m}, 1 \mathrm{H}), 4.78-4.75(\mathrm{~m}, 1 \mathrm{H}) ;{ }^{13} \mathrm{C}$ NMR $\left(125 \mathrm{MHz}, \mathrm{CDCl}_{3}\right): \delta 141.9$, 129.9, 128.4, 127.7, 126.5, 126.3, 87.8, 75.7; IR (thin film) 2954, 1612, 1512, 1454, $1245,1173,1063,829 \mathrm{~cm}^{-1}$; HRMS (ESI) $\mathrm{m} / z$ calcd for $\mathrm{C}_{10} \mathrm{H}_{11} \mathrm{O}[\mathrm{M}+\mathrm{H}]^{+}: 147.0804$, found 147.0799 .

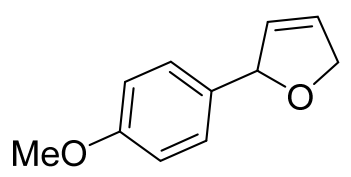

3ab

2-(4-Methoxyphenyl)-2,5-dihydrofuran (3ab), ${ }^{[4]}$ 2,3-Dihydrofuran $1 \mathbf{a}(0.15 \mathrm{~mL}, 2.0$ mmol) and diaryliodonium triflate $\mathbf{2 b}(245.0 \mathrm{mg}, 0.5 \mathrm{mmol})$ stirring at $25^{\circ} \mathrm{C}$ for $18 \mathrm{~h}$. Purification using medium pressure chromatography $(1: 10$; ethyl acetate: petroleum ether) afforded 3ab. A pale yellow oil, $75.0 \mathrm{mg}, 85 \%$ yield; ${ }^{1} \mathrm{H}$ NMR (400 MHz, $\left.\mathrm{CDCl}_{3}\right): \delta 7.23(\mathrm{~d}, J=8.4 \mathrm{~Hz}, 2 \mathrm{H}), 6.88(\mathrm{~d}, J=8.4 \mathrm{~Hz}, 2 \mathrm{H}), 6.04(\mathrm{~d}, J=4.4 \mathrm{~Hz}, 1 \mathrm{H})$, 5.86-5.84 (m, 1H), 5.76-5.72 (m, 1H), 4.86-4.82 (m, 1H), 4.74-4.71 (m, 1H), 3.79 $(\mathrm{s}, 3 \mathrm{H}) ;{ }^{13} \mathrm{C} \mathrm{NMR}\left(100 \mathrm{MHz}, \mathrm{CDCl}_{3}\right): \delta 159.2,134.0,129.9,127.8,126.6,113.8,87.4$, 75.4, 55.2; IR (thin film) 2839, 1612, 1512, 1303, 1244, 1173, 1062, $829 \mathrm{~cm}^{-1}$; HRMS (ESI) $m / z$ calcd for $\mathrm{C}_{11} \mathrm{H}_{13} \mathrm{O}_{2}[\mathrm{M}+\mathrm{H}]^{+}:$177.0910, found 177.0906. 


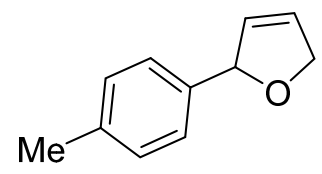

3ac

2-(p-Tolyl)-2,5-dihydrofuran (3ac) ${ }^{[5]}$ 2,3-Dihydrofuran 1a $(0.15 \mathrm{~mL}, 2.0 \mathrm{mmol})$ and diaryliodonium triflate $2 \mathrm{c}(229.0 \mathrm{mg}, 0.5 \mathrm{mmol})$ stirring at $25{ }^{\circ} \mathrm{C}$ for $24 \mathrm{~h}$. Purification using medium pressure chromatography (1:30; ethyl acetate: petroleum ether) afforded 3ac. A pale yellow oil, $60.0 \mathrm{mg}$, 75\% yield; ${ }^{1} \mathrm{H}$ NMR (400 MHz, $\left.\mathrm{CDCl}_{3}\right): \delta 7.20(\mathrm{~d}, J=8.0 \mathrm{~Hz}, 2 \mathrm{H}), 7.16(\mathrm{~d}, J=8.0 \mathrm{~Hz}, 2 \mathrm{H}), 6.03(\mathrm{~d}, J=4.8 \mathrm{~Hz}, 1 \mathrm{H})$, 5.87-5.86 (m, 1H), 5.77-5.75 (m, 1H), 4.88-4.83 (m, 1H), 4.76-4.73 (m, 1H), 2.33 $(\mathrm{s}, 3 \mathrm{H}) ;{ }^{13} \mathrm{C} \mathrm{NMR}\left(100 \mathrm{MHz}, \mathrm{CDCl}_{3}\right): \delta 138.9,137.5,130.0,129.1,126.5,126.3,87.7$, 75.6, 21.1; IR (thin film) 2924, 1687, 1481, 1606, 1513, 1181, $819 \mathrm{~cm}^{-1}$; HRMS (ESI) $m / z$ calcd for $\mathrm{C}_{11} \mathrm{H}_{13} \mathrm{O}[\mathrm{M}+\mathrm{H}]^{+}:$161.0961, found 161.0956.

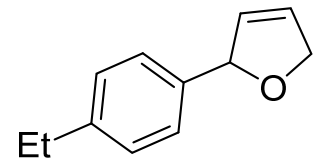

3ad

2-(4-Ethylphenyl)-2,5-dihydrofuran (3ad), 2,3-Dihydrofuran 1a (0.15 mL, 2.0 mmol) and diaryliodonium triflate $2 \mathrm{~d}(243.0 \mathrm{mg}, 0.5 \mathrm{mmol})$ stirring at $25{ }^{\circ} \mathrm{C}$ for $24 \mathrm{~h}$. Purification using medium pressure chromatography (1:30; ethyl acetate: petroleum ether) afforded 3ad. A pale yellow oil, $61.0 \mathrm{mg}, 70 \%$ yield; ${ }^{1} \mathrm{H}$ NMR (400 MHz, $\left.\mathrm{CDCl}_{3}\right): \delta 7.23(\mathrm{~d}, J=8.0 \mathrm{~Hz}, 2 \mathrm{H}), 7.18(\mathrm{~d}, J=8.0 \mathrm{~Hz}, 2 \mathrm{H}), 6.03-6.01(\mathrm{~m}, 1 \mathrm{H})$, 5.88-5.87 (m, 1H), 5.77-5.76 (m, 1H), 4.88-4.83 (m, 1H), 4.76-4.73 (m, 1H), 2.66 (q, $J=7.6 \mathrm{~Hz}, 2 \mathrm{H}), 1.23(\mathrm{t}, J=8.0 \mathrm{~Hz}, 3 \mathrm{H}) ;{ }^{13} \mathrm{C} \mathrm{NMR}\left(100 \mathrm{MHz}, \mathrm{CDCl}_{3}\right): \delta 143.9$, $139.2,129.9,127.9,126.5,126.4,87.7,75.6,28.5,15.6$; IR (thin film) 2852,1444 , 1350, 1261, 1067, 1021, $930 \mathrm{~cm}^{-1}$; HRMS (ESI) $\mathrm{m} / z$ calcd for $\mathrm{C}_{12} \mathrm{H}_{15} \mathrm{O}[\mathrm{M}+\mathrm{H}]^{+}$: 175.1117, found 175.1110

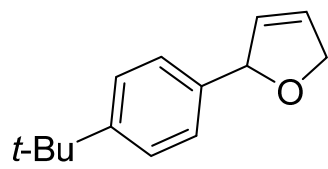

3ae

2-(4-(tert-Butyl)phenyl)-2,5-dihydrofuran (3ae) ${ }^{[6]}$ 2,3-Dihydrofuran $\mathbf{1 a}(0.15 \mathrm{~mL}$, 
$2.0 \mathrm{mmol})$ and diaryliodonium triflate $2 \mathrm{e}(271.0 \mathrm{mg}, 0.5 \mathrm{mmol})$ stirring at $25{ }^{\circ} \mathrm{C}$ for 24 h. Purification using medium pressure chromatography (1:30; ethyl acetate: petroleum ether) afforded 3ae. A pale yellow oil, $80.0 \mathrm{mg}, 79 \%$ yield; ${ }^{1} \mathrm{H}$ NMR (400 $\left.\mathrm{MHz}_{\mathrm{CDCl}}\right): \delta 7.38(\mathrm{~d}, J=8.4 \mathrm{~Hz}, 2 \mathrm{H}), 7.25(\mathrm{~d}, J=8.4 \mathrm{~Hz}, 2 \mathrm{H}), 6.03(\mathrm{~d}, J=4.4 \mathrm{~Hz}$, 1H), 5.89-5.88 (m, 1H), 5.78-5.77 (m, 1H), 4.88-4.83 (m, 1H), 4.76-4.73 (m, 1H), $1.30(\mathrm{~s}, 9 \mathrm{H}) ;{ }^{13} \mathrm{C} \mathrm{NMR}\left(100 \mathrm{MHz}, \mathrm{CDCl}_{3}\right): \delta 150.7,138.8,129.8,126.6,126.1,125.4$, 87.6, 75.6, 34.4, 31.3; IR (thin film) 2933, 1490, 1345, 1280, 1022, 880, $786 \mathrm{~cm}^{-1}$; HRMS (ESI) $m / z$ calcd for $\mathrm{C}_{14} \mathrm{H}_{19} \mathrm{O}[\mathrm{M}+\mathrm{H}]^{+}: 203.1430$, found 203.1435 .

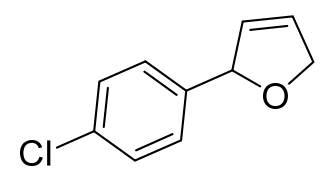

$3 a f$

2-(4-Chlorophenyl)-2,5-dihydrofuran (3af), ${ }^{[4]}$ 2,3-Dihydrofuran 1a $(0.15 \mathrm{~mL}, 2.0$ mmol) and diaryliodonium triflate $2 \mathbf{f}(248.9 \mathrm{mg}, 0.5 \mathrm{mmol})$ stirring at $25^{\circ} \mathrm{C}$ for $24 \mathrm{~h}$. Purification using medium pressure chromatography (1:30; ethyl acetate: petroleum ether) afforded 3af. A pale yellow oil, $66.0 \mathrm{mg}$, 73\% yield; ${ }^{1} \mathrm{H}$ NMR (400 MHz, $\left.\mathrm{CDCl}_{3}\right): \delta 7.30(\mathrm{~d}, J=8.0 \mathrm{~Hz}, 2 \mathrm{H}), 7.23(\mathrm{~d}, J=8.0 \mathrm{~Hz}, 2 \mathrm{H}), 6.03-6.01(\mathrm{~m}, 1 \mathrm{H})$, $5.84-5.82(\mathrm{~m}, 1 \mathrm{H}), 5.75-5.73(\mathrm{~m}, 1 \mathrm{H}), 4.86-4.82(\mathrm{~m}, 1 \mathrm{H}), 4.76-4.73(\mathrm{~m}, 1 \mathrm{H}) ;{ }^{13} \mathrm{C}$ NMR (100 MHz, $\left.\mathrm{CDCl}_{3}\right): \delta 140.5,133.3,129.5,128.5,127.6,126.9,87.0,75.7$; IR (thin film) 2851, 1620, 1596, 1491, 1261, 1070, 1124, 916, $821 \mathrm{~cm}^{-1}$; HRMS (ESI) $m / z$ calcd for $\mathrm{C}_{10} \mathrm{H}_{10} \mathrm{ClO}[\mathrm{M}+\mathrm{H}]^{+}: 181.0415$, found181.0414.

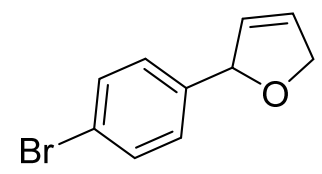

3 ag

2-(4-Bromophenyl)-2,5-dihydrofuran (3ag), ${ }^{[5]}$ 2,3-Dihydrofuran $1 \mathbf{a}(0.15 \mathrm{~mL}, 2.0$ mmol) and diaryliodonium triflate $2 \mathrm{~g}(293.9 \mathrm{mg}, 0.5 \mathrm{mmol})$ stirring at $25^{\circ} \mathrm{C}$ for $24 \mathrm{~h}$. Purification using medium pressure chromatography (1:30; ethyl acetate: petroleum ether) afforded 3ag. A colorless oil, $95.0 \mathrm{mg}, 85 \%$ yield; ${ }^{1} \mathrm{H}$ NMR (400 $\mathrm{MHz}, \mathrm{CDCl}_{3}$ ): $\delta 7.47(\mathrm{~d}, J=8.4 \mathrm{~Hz}, 2 \mathrm{H}), 7.18(\mathrm{~d}, J=8.0 \mathrm{~Hz}, 2 \mathrm{H}), 6.04-6.03(\mathrm{~m}, 1 \mathrm{H}), 5.84-5.83(\mathrm{~m}$, $1 \mathrm{H}), 5.75-5.72(\mathrm{~m}, 1 \mathrm{H}), 4.88-4.83(\mathrm{~m}, 1 \mathrm{H}), 4.77-4.74(\mathrm{~m}, 1 \mathrm{H}),{ }^{13} \mathrm{C}$ NMR $(100 \mathrm{MHz}$, 
$\left.\mathrm{CDCl}_{3}\right): \delta 141.0,131.5,129.4,128.0,126.9,121.5,87.1,75.8$; IR (thin film) 2923, 1620, 1490, 1350, 1261, 1063, 1020, 920, $831 \mathrm{~cm}^{-1}$; HRMS (ESI) $\mathrm{m} / z$ calcd for $\mathrm{C}_{10} \mathrm{H}_{10} \mathrm{BrO}[\mathrm{M}+\mathrm{H}]^{+}:$224.9910, found 224.9914.

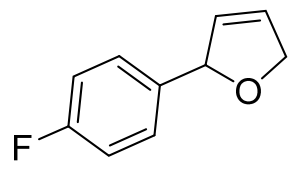

3ah

2-(4-Fluorophenyl)-2,5-dihydrofuran (3ah), ${ }^{[4]}$ 2,3-Dihydrofuran 1a $(0.15 \mathrm{~mL}, 2.0$ mmol) and diaryliodonium triflate $2 \mathbf{h}(233.0 \mathrm{mg}, 0.5 \mathrm{mmol})$ stirring at $25^{\circ} \mathrm{C}$ for $24 \mathrm{~h}$. Purification using medium pressure chromatography (1:30; ethyl acetate: petroleum ether) afforded 3ah. A pale yellow oil, $74.0 \mathrm{mg}, 85 \%$ yield; ${ }^{1} \mathrm{H}$ NMR (400 MHz, $\left.\mathrm{CDCl}_{3}\right): \delta 7.28-7.25(\mathrm{~m}, 2 \mathrm{H}), 7.04-7.00(\mathrm{~m}, 2 \mathrm{H}), 6.05-6.04(\mathrm{~m}, 1 \mathrm{H}), 5.86-5.85(\mathrm{~m}$, $1 \mathrm{H}), 5.77-5.75(\mathrm{~m}, 1 \mathrm{H}), 4.88-4.83(\mathrm{~m}, 1 \mathrm{H}), 4.77-4.73(\mathrm{~m}, 1 \mathrm{H}) ;{ }^{13} \mathrm{C} \mathrm{NMR}(100 \mathrm{MHz}$, $\left.\mathrm{CDCl}_{3}\right): \delta 163.6(\mathrm{~d}, J=244.3 \mathrm{~Hz}), 137.8(\mathrm{~d}, J=2.9 \mathrm{~Hz}), 129.7,128.2,126.9,115.4(\mathrm{~d}$, $J=21.1 \mathrm{~Hz}), 87.2,75.7 ;{ }^{19} \mathrm{~F} \mathrm{NMR}\left(376 \mathrm{MHz}, \mathrm{CDCl}_{3}\right): \delta-114.7$; IR (thin film) 2933, $1612,1445,1315,1126,1050,880,812 \mathrm{~cm}^{-1}$; HRMS (ESI) $\mathrm{m} / z$ calcd for $\mathrm{C}_{10} \mathrm{H}_{10} \mathrm{FO}$ $[\mathrm{M}+\mathrm{H}]^{+}:$165.0710, found 165.0708 .<smiles>FC(F)(F)c1ccc(C2C=CCO2)cc1</smiles>

3ai

2-(4-(Trifluoromethyl)phenyl)-2,5-dihydrofuran (3ai), ${ }^{[7]}$ 2,3-Dihydrofuran 1a $(0.15$ $\mathrm{mL}, 2.0 \mathrm{mmol})$ and diaryliodonium triflate $2 \mathbf{i}(283.0 \mathrm{mg}, 0.5 \mathrm{mmol})$ stirring at $25{ }^{\circ} \mathrm{C}$ for 24 h. Purification using medium pressure chromatography (1:30; ethyl acetate: petroleum ether) afforded 3ai. A pale yellow oil, $74.0 \mathrm{mg}, 85 \%$ yield; ${ }^{1} \mathrm{H}$ NMR (400 $\left.\mathrm{MHz}, \mathrm{CDCl}_{3}\right): \delta 7.61(\mathrm{~d}, J=8.0 \mathrm{~Hz}, 2 \mathrm{H}), 7.43(\mathrm{~d}, J=8.0 \mathrm{~Hz}, 2 \mathrm{H}), 6.07-6.05(\mathrm{~m}, 1 \mathrm{H})$, 5.89-5.84 (m, 2H), 4.92-4.87 (m, 1H), 4.82-4.79 (m, 1H); ${ }^{13} \mathrm{C}$ NMR (100 MHz, $\left.\mathrm{CDCl}_{3}\right): \delta 146.1,129.3,127.1,126.4,125.5,125.4,87.1,76.0 ;{ }^{19} \mathrm{~F}$ NMR $(376 \mathrm{MHz}$, $\left.\mathrm{CDCl}_{3}\right): \delta-62.4$; IR (thin film) 2959, 1732, 1620, 1415, 1325, 1126, 1067, $833 \mathrm{~cm}^{-1}$; HRMS (ESI) $m / z$ calcd for $\mathrm{C}_{11} \mathrm{H}_{10} \mathrm{~F}_{3} \mathrm{O}[\mathrm{M}+\mathrm{H}]^{+}: 215.0678$, found 215.0683 . 


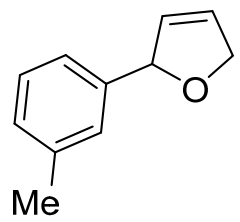

3aj

2-(m-Tolyl)-2,5-dihydrofuran (3aj) ${ }^{[4]}$ 2,3-Dihydrofuran $\mathbf{1 a}(0.15 \mathrm{~mL}, 2.0 \mathrm{mmol})$ and diaryliodonium triflate $2 \mathbf{j}(229.0 \mathrm{mg}, 0.5 \mathrm{mmol})$ stirring at $25^{\circ} \mathrm{C}$ for $24 \mathrm{~h}$. Purification using medium pressure chromatography (1:30; ethyl acetate: petroleum ether) afforded 3aj. A pale yellow oil, $56.0 \mathrm{mg}, 73 \%$ yield; ${ }^{1} \mathrm{H}$ NMR (400 MHz, $\left.\mathrm{CDCl}_{3}\right): \delta$ $7.23(\mathrm{~d}, J=7.6 \mathrm{~Hz}, 1 \mathrm{H}), 7.11-7.08(\mathrm{~m}, 3 \mathrm{H}), 6.03-6.02(\mathrm{~m}, 1 \mathrm{H}), 5.89-5.87(\mathrm{~m}, 1 \mathrm{H})$, 5.78-5.75 (m, 1H), 4.90-4.85 (m, 1H), 4.78-4.75 (m, 1H), $2.34(\mathrm{~s}, 3 \mathrm{H}) ;{ }^{13} \mathrm{C} \mathrm{NMR}$ $\left(100 \mathrm{MHz}, \mathrm{CDCl}_{3}\right): \delta 141.9,138.1,129.9,128.5,128.3,127.0,126.5,123.4,87.8$, 75.7, 21.4; IR (thin film) 3025, 2923, 1607, 1488, 1350, 1265, 1067, 878, 761 $\mathrm{cm}^{-1}$; HRMS (ESI) $m / z$ calcd for $\mathrm{C}_{11} \mathrm{H}_{13} \mathrm{O}[\mathrm{M}+\mathrm{H}]^{+}:$161.0961, found 161.0956.

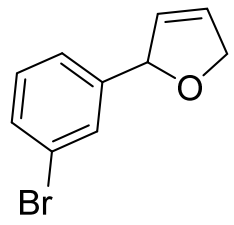

3ak

2-(3-Bromophenyl)-2,5-dihydrofuran (3ak), 2,3-Dihydrofuran 1a (0.15 mL, 2.0 mmol) and diaryliodonium triflate $2 \mathbf{k}(293.9 \mathrm{mg}, 0.5 \mathrm{mmol})$ stirring at $25^{\circ} \mathrm{C}$ for $24 \mathrm{~h}$. Purification using medium pressure chromatography (1:30; ethyl acetate: petroleum ether) afforded 3ak. A pale yellow oil, $96.0 \mathrm{mg}, 85 \%$ yield; ${ }^{1} \mathrm{H}$ NMR (400 MHz, $\left.\mathrm{CDCl}_{3}\right): \delta 7.44(\mathrm{~s}, 1 \mathrm{H}), 7.41-7.39(\mathrm{~m}, 1 \mathrm{H}), 7.22-7.18(\mathrm{~m}, 2 \mathrm{H}), 6.05-6.04(\mathrm{~m}, 1 \mathrm{H})$, $5.86-5.84(\mathrm{~m}, 1 \mathrm{H}), 5.76-5.72(\mathrm{~m}, 1 \mathrm{H}), 4.88^{-4.85}(\mathrm{~m}, 1 \mathrm{H}), 4.78-4.75(\mathrm{~m}, 1 \mathrm{H}) ;{ }^{13} \mathrm{C}$ NMR (100 MHz, $\left.\mathrm{CDCl}_{3}\right): \delta 144.4,130.7,130.0,129.4,129.3,127.0,124.9,122.6$, 87.1, 75.9; IR (thin film) 2852, 1728, 1569, 1473, 1350, 1197, 1067, $782 \mathrm{~cm}^{-1}$; HRMS (ESI) $m / z$ calcd for $\mathrm{C}_{10} \mathrm{H}_{10} \mathrm{BrO}[\mathrm{M}+\mathrm{H}]^{+}: 224.9910$, found 224.9907.<smiles>Cc1ccccc1C1C=CCO1</smiles> 
2-(o-Tolyl)-2,5-dihydrofuran (3al), ${ }^{[5]}$ 2,3-Dihydrofuran $\mathbf{1 a}(0.15 \mathrm{~mL}, 2.0 \mathrm{mmol})$ and diaryliodonium triflate $21(229.0 \mathrm{mg}, 0.5 \mathrm{mmol})$ stirring at $25^{\circ} \mathrm{C}$ for $24 \mathrm{~h}$. Purification using medium pressure chromatography (1:30; ethyl acetate: petroleum ether) afforded 3al. A pale yellow oil, $57.0 \mathrm{mg}, 72 \%$ yield; ${ }^{1} \mathrm{H}$ NMR (400 $\left.\mathrm{MHz}, \mathrm{CDCl}_{3}\right): \delta$ 7.31-7.28 (m, 1H), 7.20-7.13 (m, 3H), 6.02-6.01 (m, 2H), 5.92-5.90 (m, 1H), 4.89-4.84 (m, 1H), 4.79-4.76 (m, 1H), $2.39(\mathrm{~s}, 3 \mathrm{H}) ;{ }^{13} \mathrm{C} \mathrm{NMR}\left(100 \mathrm{MHz}, \mathrm{CDCl}_{3}\right): \delta$ $139.8,135.0,130.3,128.9,127.5,126.6,126.2,126.1,84.9,75.5,18.9$; IR (thin film) 3023, 2954, 1620, 1485, 1350, 1263, 1068, 919, $748 \mathrm{~cm}^{-1}$; HRMS (ESI) $\mathrm{m} / z$ calcd for $\mathrm{C}_{11} \mathrm{H}_{13} \mathrm{O}[\mathrm{M}+\mathrm{H}]^{+}:$161.0961, found 161.0954.

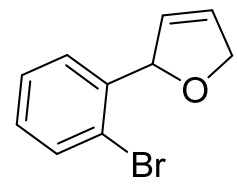

3am

2-(2-Bromophenyl)-2,5-dihydrofuran (3am), 2,3-Dihydrofuran 1a $(0.15 \mathrm{~mL}, 2.0$ mmol) and diaryliodonium triflate $2 \mathrm{~m}(293.9 \mathrm{mg}, 0.5 \mathrm{mmol})$ stirring at $25^{\circ} \mathrm{C}$ for $24 \mathrm{~h}$. Purification using medium pressure chromatography (1:30; ethyl acetate: petroleum ether) afforded 3am. A pale yellow oil, $97.0 \mathrm{mg}$, 87\% yield; ${ }^{1} \mathrm{H}$ NMR (400 MHz, $\left.\mathrm{CDCl}_{3}\right): \delta 7.52(\mathrm{~d}, J=8.0 \mathrm{~Hz}, 1 \mathrm{H}), 7.42(\mathrm{~d}, J=6.8 \mathrm{~Hz}, 1 \mathrm{H}), 7.32(\mathrm{t}, J=7.6 \mathrm{~Hz}, 1 \mathrm{H})$, $7.13(\mathrm{~d}, J=7.6 \mathrm{~Hz}, 1 \mathrm{H}), 6.13-6.10(\mathrm{~m}, 1 \mathrm{H}), 6.05-5.99$ (m, 2H), 4.94-4.89 (m, 1H), 4.84-4.80 (m, 1H); ${ }^{13} \mathrm{C}$ NMR (100 MHz, $\left.\mathrm{CDCl}_{3}\right): \delta 141.3,132.5,128.9,128.7,127.7$, 127.4, 126.5, 121.3, 86.8, 76.1; IR (thin film) 2850, 1440, 1351, 1260, 1077, 1023, $920 \mathrm{~cm}^{-1}$; HRMS (ESI) $\mathrm{m} / z$ calcd for $\mathrm{C}_{10} \mathrm{H}_{10} \mathrm{BrO}[\mathrm{M}+\mathrm{H}]^{+}: 224.9910$, found 224.9911.

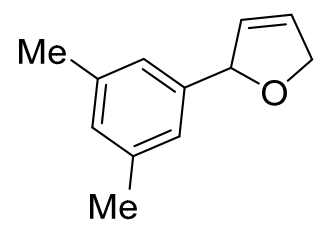

3an

2-(3,5-Dimethylphenyl)-2,5-dihydrofuran (3an), ${ }^{[7]}$ 2,3-Dihydrofuran 1a $(0.15 \mathrm{~mL}$, $2.0 \mathrm{mmol})$ and diaryliodonium triflate $2 \mathrm{n}(243.0 \mathrm{mg}, 0.5 \mathrm{mmol})$ stirring at $25^{\circ} \mathrm{C}$ for 24 h. Purification using medium pressure chromatography (1:30; ethyl acetate: petroleum ether) afforded 3an. A pale yellow oil, $60.0 \mathrm{mg}$, 69\% yield; ${ }^{1} \mathrm{H}$ NMR (400 
$\left.\mathrm{MHz}, \mathrm{CDCl}_{3}\right): \delta 6.91(\mathrm{~s}, 3 \mathrm{H}), 6.02-6.00(\mathrm{~m}, 1 \mathrm{H}), 5.87-5.86(\mathrm{~m}, 1 \mathrm{H}), 5.73-5.71(\mathrm{~m}$, 1H), 4.89-4.84 (m, 1H), 4.76-4.73 (m, 1H), $2.30(\mathrm{~m}, 6 \mathrm{H}) ;{ }^{13} \mathrm{C}$ NMR (100 MHz, $\left.\mathrm{CDCl}_{3}\right): \delta 141.8,138.0,130.0,129.4,126.4,124.1,87.8,75.7,21.2$; IR (thin film) 2925, 1620, 1490, 1337, 1262, 1136, 1053, $701 \mathrm{~cm}^{-1}$; HRMS (ESI) $\mathrm{m} / z$ calcd for $\mathrm{C}_{12} \mathrm{H}_{15} \mathrm{O}[\mathrm{M}+\mathrm{H}]^{+}:$175.1117, found 175.1116 .<smiles>CC(C)(C)OC(=O)N1CC=CC1c1ccccc1</smiles>

\section{$3 \mathbf{b a}($ rotamers ratio $=2.6: 1)$}

tert-Butyl 2-phenyl-2,5-dihydro-1H-pyrrole-1-carboxylate $\quad(3 \mathbf{b a}),{ }^{[8]}$ tert-Dutyl 2,3-dihydro-1H-pyrrole-1-carboxylate $\mathbf{1 b}(338.4 \mathrm{mg}, 2.0 \mathrm{mmol})$ and diaryliodonium triflate $2 \mathrm{a}(215.0 \mathrm{mg}, 0.5 \mathrm{mmol})$ stirring at $25^{\circ} \mathrm{C}$ for $24 \mathrm{~h}$. Purification using medium pressure chromatography (1:20; ethyl acetate: petroleum ether) afforded 3ba. A pale yellow oil, $74.0 \mathrm{mg}, 60 \%$ yield; ${ }^{1} \mathrm{H}$ NMR (400 MHz, $\left.\mathrm{CDCl}_{3}\right): \delta 7.31-7.18(\mathrm{~m}, 5 \mathrm{H})$, 5.90-5.83 (m, 1H), 5.76-5.72 (m, 1H), 5.52 (br, 0.28H), 5.37 (br, 0.72H), 4.35-4.26 (m, 2H), 1.43 (s, 2.6H), $1.20(\mathrm{~s}, 6.4 \mathrm{H}) ;{ }^{13} \mathrm{C}$ NMR (100 MHz, $\left.\mathrm{CDCl}_{3}\right): \delta 154.1,142.4$, 131.2, 128.1, 127.2, 126.6, 124.6, 79.5, 68.1, 53.6, 28.1; IR (thin film) 2976, 1699 , 1523, 1366, 1257, 1135, 1051, $761 \mathrm{~cm}^{-1}$; HRMS (ESI) $\mathrm{m} / z$ calcd for $\mathrm{C}_{15} \mathrm{H}_{20} \mathrm{NO}_{2}$ $[\mathrm{M}+\mathrm{H}]^{+}: 246.1489$, found 246.1482 .

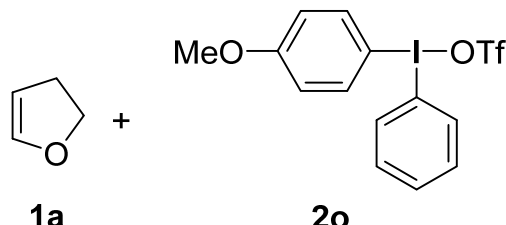

20

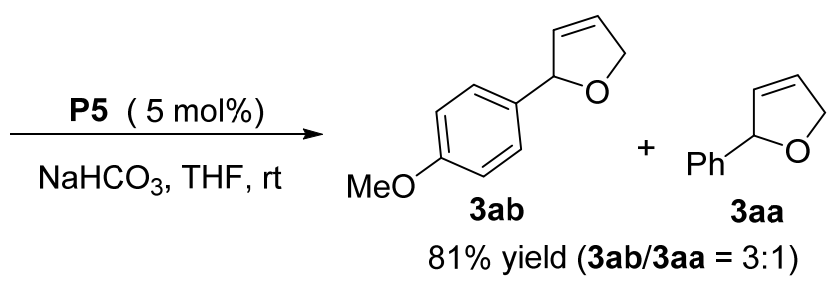

$81 \%$ yield $(3 a b / 3 a a=3: 1)$

In a $25 \mathrm{~mL}$ Schlenk flask was charged with 2,3-dihydrofuran 1a (2.0 mmol, 4.0 equiv.), diaryliodonium triflate $20(0.5 \mathrm{mmol}), \mathbf{P 5}(5 \mathrm{~mol} \%), \mathrm{NaHCO}_{3}(0.75 \mathrm{mmol}$, 1.5 equiv.), and THF ( $3 \mathrm{~mL})$ under $\mathrm{N}_{2}$. The mixture was stirred at room temperature for $18 \mathrm{~h}$ until diaryliodonium triflate 20 was completely consumed (monitored by TLC). Then, the solvent was removed under the reduced pressure and the crude product was filtered by a short column to afford crude mixture of products $\mathbf{3 a b}$ and 3aa (the ratio was determined by crude ${ }^{1} \mathrm{H}$ NMR). 


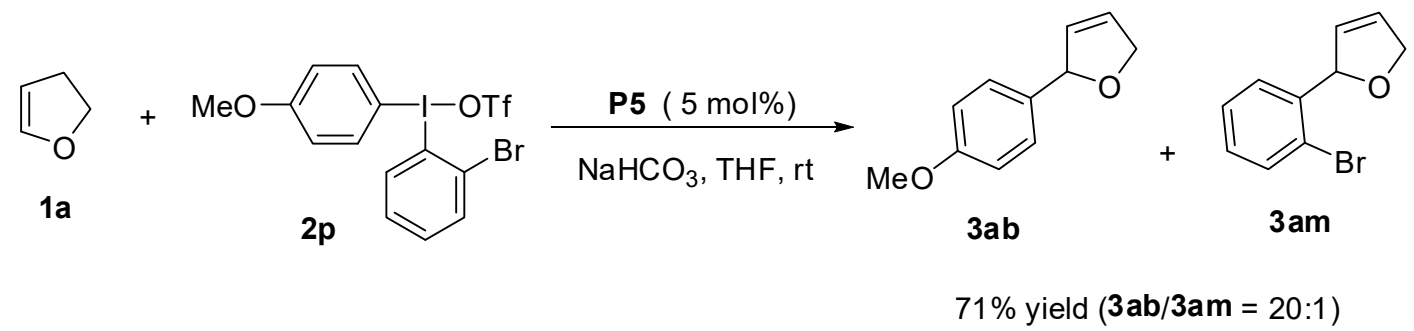

In a $25 \mathrm{~mL}$ Schlenk flask was charged with 2,3-dihydrofuran 1a $(2.0 \mathrm{mmol}, 4.0$ equiv.), diaryliodonium triflate $\mathbf{2 p}(0.5 \mathrm{mmol}), \mathbf{P 5}(5 \mathrm{~mol} \%), \mathrm{NaHCO}_{3}(0.75 \mathrm{mmol}$, 1.5 equiv.), and THF ( $3 \mathrm{~mL}$ ) under $\mathrm{N}_{2}$. The mixture was stirred at room temperature for $24 \mathrm{~h}$ until diaryliodonium triflate $\mathbf{2 p}$ was completely consumed (monitored by TLC). Then, the solvent was removed under the reduced pressure and the crude product was filtered by a short column to afford crude mixture of product 3ab as major (the ratio was determined by crude ${ }^{1} \mathrm{H}$ NMR).

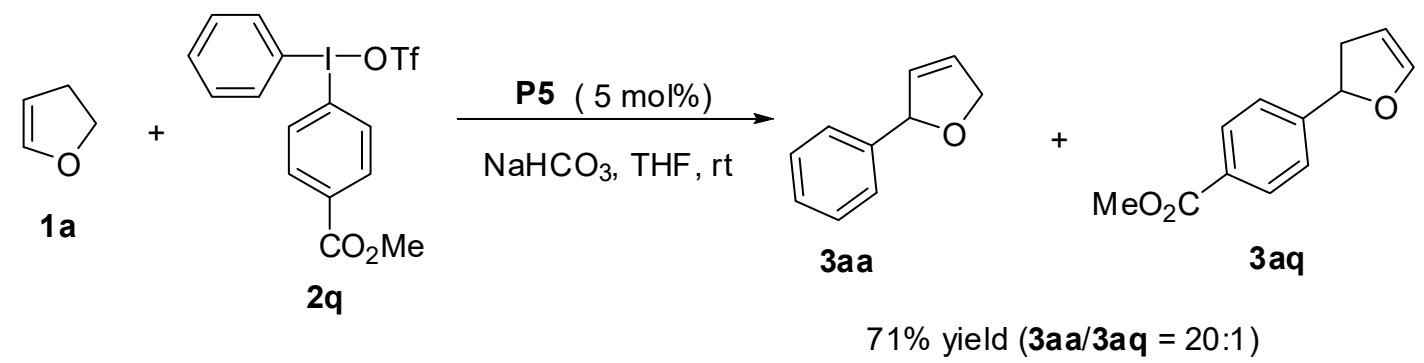

In a $25 \mathrm{~mL}$ Schlenk flask was charged with 2,3-dihydrofuran 1a $(2.0 \mathrm{mmol}, 4.0$ equiv.), diaryliodonium triflate $\mathbf{2 q}(0.5 \mathrm{mmol}), \mathbf{P 5}(5 \mathrm{~mol} \%), \mathrm{NaHCO}_{3}(0.75 \mathrm{mmol}$, 1.5 equiv.), and THF ( $3 \mathrm{~mL}$ ) under $\mathrm{N}_{2}$. The mixture was stirred at room temperature for $24 \mathrm{~h}$ until diaryliodonium triflate $\mathbf{2 q}$ was completely consumed (monitored by TLC). Then, the solvent was removed under the reduced pressure and the crude product was filtered by a short column to afford crude mixture of product 3aa as major (the ratio was determined by crude ${ }^{1} \mathrm{H}$ NMR).

\section{Synthesis of compounds 4aa-4ar}

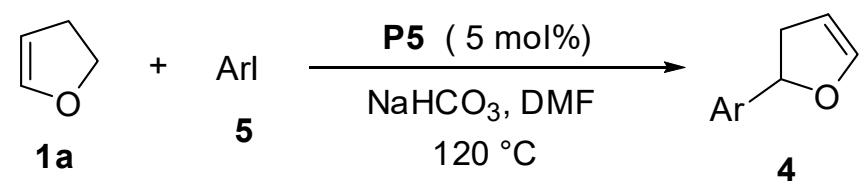

In a $25 \mathrm{~mL}$ Schlenk falsk was charged with 2,3-dihydrofuran 1a $(2.0 \mathrm{mmol}, 4.0$ equiv.), aryliodides 5 (0.5 mmol), P5 (5 mol \%), $\mathrm{NaHCO}_{3}(0.75 \mathrm{mmol}, 1.5$ equiv.), and DMF (3 mL) under $\mathrm{N}_{2}$. The reaction mixture was heated to $120^{\circ} \mathrm{C}$ in an oil bath 
for 3-5 h. After the completion of the reaction, the solvent was removed under the reduced pressure and the crude product was purified by flash column chromatography (the crude residue was dryloaded with silical gel, 1/50 to 1/30; ethyl acetate/petroleum ether) to afford product 4.

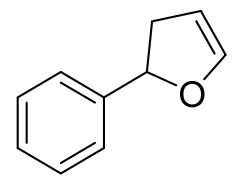

4aa

2-Phenyl-2,3-dihydrofuran (4aa), ${ }^{[9]}$ 2,3-Dihydrofuran 1 a $(0.15 \mathrm{~mL}, 2.0 \mathrm{mmol})$ and aryliodide 5a (102.0 mg, $0.5 \mathrm{mmol})$ stirring at $120{ }^{\circ} \mathrm{C}$ for $3 \mathrm{~h}$. Purification using medium pressure chromatography (1:30; ethyl acetate: petroleum ether) afforded 4aa. A pale yellow oil, $61.0 \mathrm{mg}, 83 \%$ yield; ${ }^{1} \mathrm{H}$ NMR (400 MHz, $\left.\mathrm{CDCl}_{3}\right): \delta 7.36$ (d, $J=4.5$ $\mathrm{Hz}, 4 \mathrm{H}), 7.30-7.28(\mathrm{~m}, 1 \mathrm{H}), 6.45-6.45(\mathrm{~m}, 1 \mathrm{H}), 5.54-5.50(\mathrm{~m}, 1 \mathrm{H}), 4.96-4.95(\mathrm{~m}$, $1 \mathrm{H}), 3.10-3.05(\mathrm{~m}, 1 \mathrm{H}), 2.64-2.59(\mathrm{~m}, 1 \mathrm{H}) ;{ }^{13} \mathrm{C} \mathrm{NMR}\left(100 \mathrm{MHz}, \mathrm{CDCl}_{3}\right): \delta 145.2$, 143.0, 128.5, 127.6, 125.5, 99.0, 82.3, 37.8; IR (thin film) 2926, 1620, 1453, 1425, 1261, 1136, 1052, $699 \mathrm{~cm}^{-1}$; HRMS (ESI) $\mathrm{m} / z$ calcd for $\mathrm{C}_{10} \mathrm{H}_{11} \mathrm{O}[\mathrm{M}+\mathrm{H}]^{+}: 147.0804$, found 147.0798.

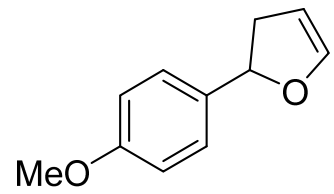

4ab

2-(4-Methoxyphenyl)-2,3-dihydrofuran (4ab), ${ }^{[7]}$ 2,3-Dihydrofuran 1a (0.15 mL, 2.0 mmol) and aryliodide $\mathbf{5 b}(117.0 \mathrm{mg}, 0.5 \mathrm{mmol})$ stirring at $120^{\circ} \mathrm{C}$ for $3 \mathrm{~h}$. Purification using medium pressure chromatography (1:10; ethyl acetate: petroleum ether) afforded 4ab. A pale yellow oil, $64.0 \mathrm{mg}, 73 \%$ yield; ${ }^{1} \mathrm{H}$ NMR (400 MHz, $\left.\mathrm{CDCl}_{3}\right): \delta$ $7.21(\mathrm{~d}, J=8.4 \mathrm{~Hz}, 2 \mathrm{H}), 6.80(\mathrm{~d}, J=8.4 \mathrm{~Hz}, 2 \mathrm{H}), 6.33(\mathrm{~d}, J=2.0 \mathrm{~Hz}, 1 \mathrm{H}), 5.39$ (t, $J=$ $9.2 \mathrm{~Hz}, 1 \mathrm{H}), 4.86(\mathrm{~d}, J=2.4 \mathrm{~Hz}, 1 \mathrm{H}), 3.70(\mathrm{~s}, 3 \mathrm{H}), 2.96-2.90(\mathrm{~m}, 1 \mathrm{H}), 2.54-2.48(\mathrm{~m}$, $1 \mathrm{H}) ;{ }^{13} \mathrm{C} \mathrm{NMR}\left(100 \mathrm{MHz}, \mathrm{CDCl}_{3}\right): \delta 159.1,145.1,134.9,127.0,113.8,98.9,82.1$, 55.1, 37.5; IR (thin film) 2925, 1622, 1469, 1353, 1268, 1137, 1054, $752 \mathrm{~cm}^{-1}$; HRMS (ESI) $m / z$ calcd for $\mathrm{C}_{11} \mathrm{H}_{13} \mathrm{O}_{2}[\mathrm{M}+\mathrm{H}]^{+}:$177.0910, found 177.0905. 


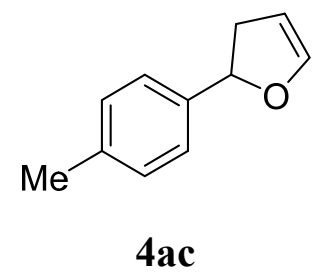

2-(p-Tolyl)-2,3-dihydrofuran (4ac) ${ }^{[10]} 2,3$-Dihydrofuran 1a $(0.15 \mathrm{~mL}, 2.0 \mathrm{mmol})$ and aryliodide 5c (109.0 mg, $0.5 \mathrm{mmol})$ stirring at $120^{\circ} \mathrm{C}$ for $3 \mathrm{~h}$. Purification using medium pressure chromatography (1:30; ethyl acetate: petroleum ether) afforded 4ac. A pale yellow oil, $68.0 \mathrm{mg}, 85 \%$ yield; ${ }^{1} \mathrm{H}$ NMR (500 MHz, $\left.\mathrm{CDCl}_{3}\right): \delta 7.25(\mathrm{~d}, J=8$ $\mathrm{Hz}, 2 \mathrm{H}), 7.16$ (d, $J=7.5 \mathrm{~Hz}, 2 \mathrm{H}), 6.43$ (d, $J=7.5 \mathrm{~Hz}, 1 \mathrm{H}), 5.49$ (t, $J=9.5 \mathrm{~Hz}, 1 \mathrm{H})$, $4.94(\mathrm{~d}, J=2 \mathrm{~Hz}, 1 \mathrm{H}), 3.06(\mathrm{t}, J=13.0 \mathrm{~Hz}, 1 \mathrm{H}), 2.61-2.57(\mathrm{~m}, 1 \mathrm{H}), 2.34(\mathrm{~s}, 3 \mathrm{H}) ;{ }^{13} \mathrm{C}$ NMR (125 MHz, $\left.\mathrm{CDCl}_{3}\right): \delta 145.2,140.0,137.3,129.3,125.8,99.0,82.3,37.7$; IR (thin film) 3025, 2924, 1620, 1515, 1338, 1262, 936, $809 \mathrm{~cm}^{-1}$; HRMS (ESI) $\mathrm{m} / z$ calcd for $\mathrm{C}_{11} \mathrm{H}_{13} \mathrm{O}[\mathrm{M}+\mathrm{H}]^{+}:$161.0961, found 161.0956.

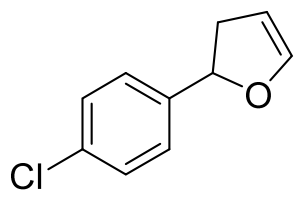

4ad

2-(4-Chlorophenyl)-2,3-dihydrofuran (4ad), ${ }^{[7]}$ 2,3-Dihydrofuran 1a $(0.15 \mathrm{~mL}, 2.0$ mmol) and aryliodide $5 \mathbf{d}(119.0 \mathrm{mg}, 0.5 \mathrm{mmol})$ stirring at $120^{\circ} \mathrm{C}$ for $4 \mathrm{~h}$. Purification using medium pressure chromatography (1:30; ethyl acetate: petroleum ether) afforded 4ad. A pale yellow oil, $67.0 \mathrm{mg}, 75 \%$ yield; ${ }^{1} \mathrm{H} \mathrm{NMR}\left(500 \mathrm{MHz}, \mathrm{CDCl}_{3}\right): \delta$ $7.33(\mathrm{~d}, J=9.0 \mathrm{~Hz}, 2 \mathrm{H}), 7.30(\mathrm{~d}, J=8.5 \mathrm{~Hz}, 2 \mathrm{H}), 6.43(\mathrm{~d}, J=1.5 \mathrm{~Hz}, 1 \mathrm{H}), 5.50(\mathrm{t}, J$ $=9.0 \mathrm{~Hz}, 1 \mathrm{H}), 4.96(\mathrm{~d}, J=2.0 \mathrm{~Hz}, 1 \mathrm{H}), 3.10(\mathrm{t}, J=9.0 \mathrm{~Hz}, 1 \mathrm{H}), 2.57-2.52(\mathrm{~m}, 1 \mathrm{H})$; ${ }^{13} \mathrm{C} \mathrm{NMR}\left(125 \mathrm{MHz}, \mathrm{CDCl}_{3}\right): \delta 145.2,141.5,133.3,128.6,127.0,99.0,81.5,37.8 . \mathrm{IR}$ (thin film) 2925, 1622, 1469, 1353, 1268, 1137, 1054, $752 \mathrm{~cm}^{-1}$; HRMS (ESI) $\mathrm{m} / z$ calcd for $\mathrm{C}_{10} \mathrm{H}_{10} \mathrm{ClO}[\mathrm{M}+\mathrm{H}]^{+}:$181.0415, found 181.0415 .<smiles>Brc1ccc(C2CC=CO2)cc1</smiles>

4ae

2-(4-Bromophenyl)-2,3-dihydrofuran (4ae) ${ }^{[10]}$ 2,3-Dihydrofuran 1a $(0.15 \mathrm{~mL}, 2.0$ 
mmol) and aryliodide 5e (140.9 mg, $0.5 \mathrm{mmol})$ stirring at $120^{\circ} \mathrm{C}$ for $4 \mathrm{~h}$. Purification using medium pressure chromatography (1:30; ethyl acetate: petroleum ether) afforded 4ae. A pale yellow oil, $67.0 \mathrm{mg}, 60 \%$ yield ${ }^{1} \mathrm{H}$ NMR (400 MHz, $\left.\mathrm{CDCl}_{3}\right): \delta$ $7.48(\mathrm{~d}, J=6.8 \mathrm{~Hz}, 2 \mathrm{H}), 7.23(\mathrm{~d}, J=6.4 \mathrm{~Hz}, 2 \mathrm{H}), 6.44(\mathrm{~d}, J=1.6 \mathrm{~Hz}, 1 \mathrm{H}), 5.48(\mathrm{t}, J=$ $7.2 \mathrm{~Hz}, 1 \mathrm{H}), 4.95$ (d, $J=1.6 \mathrm{~Hz}, 1 \mathrm{H}), 3.10(\mathrm{t}, J=10.4 \mathrm{~Hz}, 1 \mathrm{H}), 2.56-2.52(\mathrm{~m}, 1 \mathrm{H})$; ${ }^{13} \mathrm{C}$ NMR $\left(100 \mathrm{MHz}, \mathrm{CDCl}_{3}\right): \delta 145.2,142.1,131.5,127.2,121.3,98.9,81.5,37.8$; HRMS (ESI) $m / z$ calcd for $\mathrm{C}_{10} \mathrm{H}_{10} \mathrm{BrO}[\mathrm{M}+\mathrm{H}]^{+}: 224.9910$, found 224.9901 .

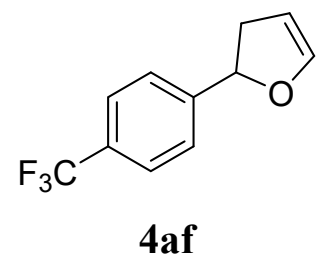

2-(4-(Trifluoromethyl)phenyl)-2,3-dihydrofuran (4af), ${ }^{[7]}$ 2,3-Dihydrofuran 1a (0.15 $\mathrm{mL}, 2.0 \mathrm{mmol})$ and aryliodide $\mathbf{5 f}(136.0 \mathrm{mg}, 0.5 \mathrm{mmol})$ stirring at $120{ }^{\circ} \mathrm{C}$ for $5 \mathrm{~h}$. Purification using medium pressure chromatography (1:30; ethyl acetate: petroleum ether) afforded 4af. A pale yellow oil, $91.0 \mathrm{mg}, 85 \%$ yield; ${ }^{1} \mathrm{H}$ NMR (400 MHz, $\left.\mathrm{CDCl}_{3}\right): \delta 7.62(\mathrm{~d}, J=8.0 \mathrm{~Hz}, 2 \mathrm{H}), 7.47(\mathrm{~d}, J=7.6 \mathrm{~Hz}, 2 \mathrm{H}), 6.47(\mathrm{~d}, J=1.6 \mathrm{~Hz}, 1 \mathrm{H})$, $5.59(\mathrm{t}, J=8.8 \mathrm{~Hz}, 1 \mathrm{H}), 4.97(\mathrm{~d}, J=2.0 \mathrm{~Hz}, 1 \mathrm{H}), 3.16-3.10(\mathrm{~m}, 1 \mathrm{H}), 2.59-2.53(\mathrm{~m}$, $1 \mathrm{H}) ;{ }^{13} \mathrm{C}$ NMR $\left(100 \mathrm{MHz}, \mathrm{CDCl}_{3}\right): \delta 147.1,145.3,129.9$ (q, $\left.J=32.0 \mathrm{~Hz}\right), 125.7$, 125.5 (q, $J=3.6 \mathrm{~Hz}), 122.7$ (q, $J=269.7 \mathrm{~Hz}$ ), 99.0, 81.4, 37.9; IR (thin film) 2932, $1620,1418,1327,1266,1127,1069,843 \mathrm{~cm}^{-1}$; HRMS (ESI) $\mathrm{m} / z$ calcd for $\mathrm{C}_{11} \mathrm{H}_{10} \mathrm{~F}_{3} \mathrm{O}$ $[\mathrm{M}+\mathrm{H}]^{+}: 215.0678$, found 215.0674 .

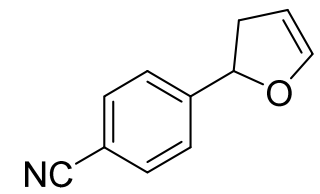

4ag

4-(2,3-Dihydrofuran-2-yl)benzonitrile (4ag) ${ }^{[7]}$ 2,3-Dihydrofuran 1 a $(0.15 \mathrm{~mL}, 2.0$ mmol) and aryliodide $5 \mathrm{~g}(114.5 \mathrm{mg}, 0.5 \mathrm{mmol})$ stirring at $120{ }^{\circ} \mathrm{C}$ for $5 \mathrm{~h}$. Purification using medium pressure chromatography (1:20; ethyl acetate: petroleum ether) afforded 4ag. A pale yellow oil, $74.0 \mathrm{mg}, 86 \%$ yield; ${ }^{1} \mathrm{H}$ NMR (500 $\left.\mathrm{MHz}, \mathrm{CDCl}_{3}\right): \delta$ $7.65(\mathrm{~d}, J=3.5 \mathrm{~Hz}, 2 \mathrm{H}), 7.46(\mathrm{~d}, J=9.0 \mathrm{~Hz}, 2 \mathrm{H}), 6.46(\mathrm{~d}, J=1.2 \mathrm{~Hz}, 1 \mathrm{H}), 5.57$ (t, $J=$ $8.5 \mathrm{~Hz}, 1 \mathrm{H}), 4.97(\mathrm{~d}, J=2.5 \mathrm{~Hz}, 1 \mathrm{H}), 3.17(\mathrm{t}, J=12.5 \mathrm{~Hz}, 1 \mathrm{H}), 2.55-2.52(\mathrm{~m}, 1 \mathrm{H})$; 
${ }^{13} \mathrm{C}$ NMR (100 MHz, $\left.\mathrm{CDCl}_{3}\right): \delta$ 148.4, 145.2, 132.3, 126.0, 118.7, 111.2, 98.9, 81.0, 37.8; IR (thin film) 2925, 1622, 1469, 1353, 1268, 1137, 1054, $752 \mathrm{~cm}^{-1}$; HRMS (ESI) $m / z$ calcd for $\mathrm{C}_{11} \mathrm{H}_{10} \mathrm{NO}[\mathrm{M}+\mathrm{H}]^{+}:$172.0757, found 172.0756.

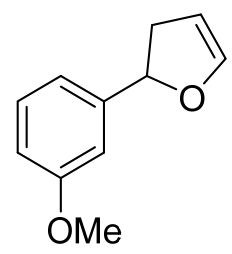

4ah

2-(3-Methoxyphenyl)-2,3-dihydrofuran (4ah), ${ }^{[7]}$ 2,3-Dihydrofuran $\mathbf{1 a}(0.15 \mathrm{~mL}, 2.0$ mmol) and aryliodide $\mathbf{5 h}(117.0 \mathrm{mg}, 0.5 \mathrm{mmol})$ stirring at $120^{\circ} \mathrm{C}$ for $3 \mathrm{~h}$. Purification using medium pressure chromatography (1:10; ethyl acetate: petroleum ether) afforded 4ah. A pale yellow oil, $77.0 \mathrm{mg}, 87 \%$ yield; ${ }^{1} \mathrm{H}$ NMR (500 MHz, $\left.\mathrm{CDCl}_{3}\right): \delta$ $7.28(\mathrm{t}, J=9.0 \mathrm{~Hz}, 1 \mathrm{H}), 6.94(\mathrm{~d}, J=9.5 \mathrm{~Hz}, 2 \mathrm{H}), 6.83(\mathrm{~d}, J=7.5 \mathrm{~Hz}, 1 \mathrm{H}), 6.44(\mathrm{~s}, 1 \mathrm{H})$, $5.50(\mathrm{t}, J=9.5 \mathrm{~Hz}, 1 \mathrm{H}), 4.95(\mathrm{~d}, J=1.5 \mathrm{~Hz}, 1 \mathrm{H}), 3.80(\mathrm{~s}, 3 \mathrm{H}), 3.09$ (t, $J=13.0 \mathrm{~Hz}$, 1H), 2.62-6.57 (m, 1H); ${ }^{13} \mathrm{C}$ NMR (125 MHz, $\left.\mathrm{CDCl}_{3}\right): \delta 159.7,145.2,144.6,129.5$, 117.8, 113.0, 110.9, 99.0, 82.1, 55.1, 37.8; HRMS (ESI) $m / z$ calcd for $\mathrm{C}_{11} \mathrm{H}_{13} \mathrm{O}_{2}$ $[\mathrm{M}+\mathrm{H}]^{+}:$177.0910, found 177.0906.

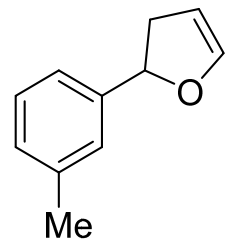

4ai

2-(m-Tolyl)-2,3-dihydrofuran (4ai), ${ }^{[11]}$ 2,3-Dihydrofuran 1a $(0.15 \mathrm{~mL}, 2.0 \mathrm{mmol})$ and aryliodide 5i (109.0 mg, $0.5 \mathrm{mmol})$ stirring at $120^{\circ} \mathrm{C}$ for $4 \mathrm{~h}$. Purification using medium pressure chromatography (1:30; ethyl acetate: petroleum ether) afforded 4ai. A pale yellow oil, $56.0 \mathrm{mg}, 70 \%$ yield; ${ }^{1} \mathrm{H}$ NMR (400 MHz, $\left.\mathrm{CDCl}_{3}\right): \delta 7.26-7.14(\mathrm{~m}$, $3 \mathrm{H}), 7.10(\mathrm{~d}, J=6.8 \mathrm{~Hz}, 1 \mathrm{H}), 6.44(\mathrm{~s}, 1 \mathrm{H}), 5.50(\mathrm{t}, J=10.0 \mathrm{~Hz}, 1 \mathrm{H}), 4.93(\mathrm{~s}, 1 \mathrm{H})$, $3.08(\mathrm{t}, J=13.8 \mathrm{~Hz}, 1 \mathrm{H}), 2.63-2.57(\mathrm{~m}, 1 \mathrm{H}), 2.35(\mathrm{~s}, 3 \mathrm{H}) ;{ }^{13} \mathrm{C} \mathrm{NMR}(100 \mathrm{MHz}$, $\left.\mathrm{CDCl}_{3}\right): \delta 145.3,142.9,138.1,128.4,128.3,162.2,122.6,99.0,82.4,37.8,21.4$; IR (thin film) 2935, 1688, 1586, 1463, 1204, 1136, 1050, $829 \mathrm{~cm}^{-1}$; HRMS (ESI) $\mathrm{m} / z$ calcd for $\mathrm{C}_{11} \mathrm{H}_{13} \mathrm{O}[\mathrm{M}+\mathrm{H}]^{+}:$161.0961, found 161.0960. 


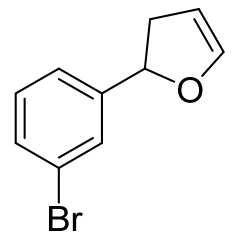

4aj

2-(3-Bromophenyl)-2,3-dihydrofuran (4aj), 2,3-Dihydrofuran 1a (0.15 mL, 2.0 mmol) and aryliodide 5j (140.9 mg, $0.5 \mathrm{mmol})$ stirring at $120^{\circ} \mathrm{C}$ for $4 \mathrm{~h}$. Purification using medium pressure chromatography (1:30; ethyl acetate: petroleum ether) afforded 4aj. A pale yellow oil, $95.0 \mathrm{mg}, 85 \%$ yield; ${ }^{1} \mathrm{H}$ NMR (500 MHz, $\left.\mathrm{CDCl}_{3}\right): \delta$ $7.51(\mathrm{~s}, 1 \mathrm{H}), 7.42(\mathrm{~d}, J=7.0 \mathrm{~Hz}, 1 \mathrm{H}), 7.27-7.20(\mathrm{~m}, 2 \mathrm{H}), 6.44-6.40(\mathrm{~m}, 1 \mathrm{H})$, 5.49-5.45 (m, 1H), 4.95-4.91 (m, 1H), $3.11(\mathrm{t}, J=12.0 \mathrm{~Hz}, 1 \mathrm{H}), 2.58(\mathrm{q}, J=15.0 \mathrm{~Hz}$, $1 \mathrm{H}) ;{ }^{13} \mathrm{C}$ NMR $\left(125 \mathrm{MHz}, \mathrm{CDCl}_{3}\right): \delta 145.4,145.2,130.6,130.0,128.5,124.1,122.6$, 99.0, 81.3, 37.8; IR (thin film) 2932, 1731, 1620, 1417, 1327, 1126, 1058, $843 \mathrm{~cm}^{-1}$; HRMS (ESI) $m / z$ calcd for $\mathrm{C}_{10} \mathrm{H}_{10} \mathrm{BrO}[\mathrm{M}+\mathrm{H}]^{+}: 224.9910$, found 224.9917 .<smiles>O=[N+]([O-])c1cccc(C2CC=CO2)c1</smiles>

4ak

2-(3-Nitrophenyl)-2,3-dihydrofuran (4ak), 2,3-Dihydrofuran 1a $(0.15 \mathrm{~mL}, 2.0$ mmol) and aryliodide $5 \mathbf{k}(124.5 \mathrm{mg}, 0.5 \mathrm{mmol})$ stirring at $120^{\circ} \mathrm{C}$ for $5 \mathrm{~h}$. Purification using medium pressure chromatography (1:20; ethyl acetate: petroleum ether) afforded 4ak. A pale yellow oil, $82.0 \mathrm{mg}, 85 \%$ yield; ${ }^{1} \mathrm{H}$ NMR $\left(500 \mathrm{MHz}, \mathrm{CDCl}_{3}\right): \delta$ $8.22(\mathrm{~s}, 1 \mathrm{H}), 8.15(\mathrm{~d}, J=9.0 \mathrm{~Hz}, 1 \mathrm{H}), 7.69(\mathrm{~d}, J=8.0 \mathrm{~Hz}, 1 \mathrm{H}), 7.55(\mathrm{t}, J=8.0 \mathrm{~Hz}, 1 \mathrm{H})$ $6.48(\mathrm{~d}, J=2.0 \mathrm{~Hz}, 1 \mathrm{H}), 5.62(\mathrm{t}, J=7.5 \mathrm{~Hz}, 1 \mathrm{H}), 5.00(\mathrm{~d}, J=2.5 \mathrm{~Hz}, 1 \mathrm{H}), 3.20(\mathrm{t}, J=$ $11.0 \mathrm{~Hz}, 1 \mathrm{H}), 2.60-2.56(\mathrm{~m}, 1 \mathrm{H}) ;{ }^{13} \mathrm{C} \mathrm{NMR}\left(125 \mathrm{MHz}, \mathrm{CDCl}_{3}\right): \delta 148.3,145.3,145.2$, 131.6, 129.5, 122.5, 120.5, 99.0, 80.8, 37.9; IR (thin film) 2910, 1633, 1502,1360, $1100,458 \mathrm{~cm}^{-1}$; HRMS (ESI) $\mathrm{m} / z$ calcd for $\mathrm{C}_{10} \mathrm{H}_{10} \mathrm{NO}_{3}[\mathrm{M}+\mathrm{H}]^{+}$: 192.0655 , found 192.0650 


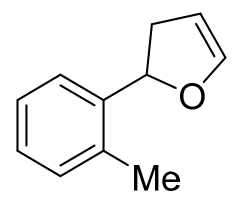

4al

2-(o-Tolyl)-2,3-dihydrofuran (4al), ${ }^{[7]}$ 2,3-Dihydrofuran $\mathbf{1 a}(0.15 \mathrm{~mL}, 2.0 \mathrm{mmol})$ and aryliodide 5l (109.0 mg, $0.5 \mathrm{mmol})$ stirring at $120{ }^{\circ} \mathrm{C}$ for $4 \mathrm{~h}$. Purification using medium pressure chromatography (1:30; ethyl acetate: petroleum ether) afforded 4al. A pale yellow oil, $55.0 \mathrm{mg}, 69 \%$ yield; ${ }^{1} \mathrm{H}$ NMR (400 MHz, $\left.\mathrm{CDCl}_{3}\right): \delta 7.40(\mathrm{~d}, J=$ $6.8 \mathrm{~Hz}, 1 \mathrm{H}), 7.21-7.15(\mathrm{~m}, 3 \mathrm{H}), 6.46(\mathrm{~s}, 1 \mathrm{H}), 5.69(\mathrm{t}, J=9.6 \mathrm{~Hz}, 1 \mathrm{H}), 4.92(\mathrm{~d}, J=1.2$ $\mathrm{Hz}, 1 \mathrm{H}), 3.12(\mathrm{t}, J=13.2 \mathrm{~Hz}, 1 \mathrm{H}), 2.46-2.36(\mathrm{~m}, 1 \mathrm{H}), 2.29(\mathrm{~s}, 3 \mathrm{H}) ;{ }^{13} \mathrm{C}$ NMR $(100$ $\left.\mathrm{MHz}_{2} \mathrm{CDCl}_{3}\right): \delta 145.2,141.0,133.9,130.2,127.1,126.0,124.6,98.7,79.8,36.8,19.0$; HRMS (ESI) $m / z$ calcd for $\mathrm{C}_{11} \mathrm{H}_{13} \mathrm{O}[\mathrm{M}+\mathrm{H}]^{+}:$161.0961, found 161.0955.<smiles>Brc1ccccc1C1CC=CO1</smiles>

4 am

2-(2-Bromophenyl)-2,3-dihydrofuran (4am), 2,3-Dihydrofuran 1a (0.15 mL, 2.0 mmol) and aryliodide $5 \mathrm{~m}(140.9 \mathrm{mg}, 0.5 \mathrm{mmol})$ stirring at $120{ }^{\circ} \mathrm{C}$ for $4 \mathrm{~h}$. Purification using medium pressure chromatography (1:30; ethyl acetate: petroleum ether) afforded 4am. A pale yellow oil, $60.0 \mathrm{mg}, 53 \%$ yield; ${ }^{1} \mathrm{H}$ NMR (400 MHz, $\left.\mathrm{CDCl}_{3}\right): \delta$ $7.55(\mathrm{~d}, J=8.0 \mathrm{~Hz}, 1 \mathrm{H}), 7.46(\mathrm{~d}, J=7.6 \mathrm{~Hz}, 1 \mathrm{H}), 7.33(\mathrm{t}, J=7.6 \mathrm{~Hz}, 1 \mathrm{H}), 7.16(\mathrm{t}, J=$ $7.2 \mathrm{~Hz}, 1 \mathrm{H}), 6.51(\mathrm{~d}, J=2.4 \mathrm{~Hz}, 1 \mathrm{H}), 5.79-5.74(\mathrm{~m}, 1 \mathrm{H}), 4.94(\mathrm{~d}, J=2.4 \mathrm{~Hz}, 1 \mathrm{H})$, $3.31(\mathrm{t}, J=13.2 \mathrm{~Hz}, 1 \mathrm{H}), 2.44-2.38(\mathrm{~m}, 1 \mathrm{H}) ;{ }^{13} \mathrm{C} \mathrm{NMR}\left(100 \mathrm{MHz}, \mathrm{CDCl}_{3}\right): \delta 145.1$, $142.5,132.6,128.7,127.5,126.3,120.8,98.9,81.1,37.2$; IR (thin film) 2925, 1622, 1469, 1353, 1268, 1137, 1054, $752 \mathrm{~cm}^{-1}$; HRMS (ESI) $\mathrm{m} / z$ calcd for $\mathrm{C}_{10} \mathrm{H}_{10} \mathrm{BrO}$ $[\mathrm{M}+\mathrm{H}]^{+}:$224.9910, found 224.9902.<smiles>FC(F)(F)c1ccccc1C1CC=CO1</smiles>

4an

2-(2-(Trifluoromethyl)phenyl)-2,3-dihydrofuran (4an), ${ }^{[12]}$ 2,3-Dihydrofuran 1 a 
$(0.15 \mathrm{~mL}, 2.0 \mathrm{mmol})$ and aryliodide $\mathbf{5 n}(136.0 \mathrm{mg}, 0.5 \mathrm{mmol})$ stirring at $120{ }^{\circ} \mathrm{C}$ for 5 h. Purification using medium pressure chromatography $(1: 15$; ethyl acetate: petroleum ether) afforded 4an. A pale yellow oil, $91.0 \mathrm{mg}, 85 \%$ yield; ${ }^{1} \mathrm{H}$ NMR (400 MHz, $\left.\mathrm{CDCl}_{3}\right): \delta 8.22(\mathrm{~d}, J=6.4 \mathrm{~Hz}, 2 \mathrm{H}), 7.52(\mathrm{~d}, J=6.8 \mathrm{~Hz}, 2 \mathrm{H}), 6.49-6.47(\mathrm{~m}, 1 \mathrm{H}), 5.63$ $(\mathrm{t}, J=6.8 \mathrm{~Hz}, 1 \mathrm{H}), 4.98(\mathrm{~s}, 1 \mathrm{H}), 3.20(\mathrm{t}, J=10.0 \mathrm{~Hz}, 1 \mathrm{H}), 2.57-2.52(\mathrm{~m}, 1 \mathrm{H}) ;{ }^{13} \mathrm{C}$ NMR (100 MHz, $\left.\mathrm{CDCl}_{3}\right): \delta 150.4,147.3,145.2,126.2,123.8,99.0,80.9,37.9$; IR (thin film) 2930, 1622, 1521, 1348, 1291, 1136, 1050, $854 \mathrm{~cm}^{-1}$; HRMS (ESI) $\mathrm{m} / z$ calcd for $\mathrm{C}_{11} \mathrm{H}_{10} \mathrm{~F}_{3} \mathrm{O}[\mathrm{M}+\mathrm{H}]^{+}: 215.1912$, found 215.1920 .

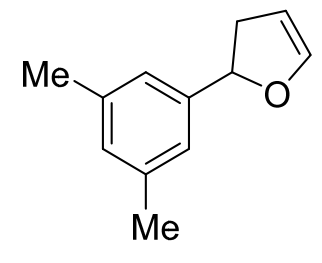

$4 a 0$

2-(3,5-Dimethylphenyl)-2,3-dihydrofuran (4ao), ${ }^{[7]}$ 2,3-Dihydrofuran 1 a $(0.15 \mathrm{~mL}$, $2.0 \mathrm{mmol})$ and aryliodide $50(116.0 \mathrm{mg}, 0.5 \mathrm{mmol})$ stirring at $120{ }^{\circ} \mathrm{C}$ for $5 \mathrm{~h}$. Purification using medium pressure chromatography (1:30; ethyl acetate: petroleum ether) afforded 4ao. A pale yellow oil, $65.0 \mathrm{mg}, 74 \%$ yield; ${ }^{1} \mathrm{H}$ NMR (500 MHz, $\left.\mathrm{CDCl}_{3}\right): \delta 6.97(\mathrm{~s}, 2 \mathrm{H}), 6.92(\mathrm{~s}, 1 \mathrm{H}), 6.43(\mathrm{~d}, J=1.5 \mathrm{~Hz}, 1 \mathrm{H}), 5.46(\mathrm{t}, J=9.5 \mathrm{~Hz}, 1 \mathrm{H})$, $4.95(\mathrm{~d}, J=2.0 \mathrm{~Hz}, 1 \mathrm{H}), 3.06(\mathrm{t}, J=15.0 \mathrm{~Hz}, 1 \mathrm{H}), 2.62-2.57(\mathrm{~m}, 1 \mathrm{H}), 2.31(\mathrm{~s}, 6 \mathrm{H})$; ${ }^{13} \mathrm{C}$ NMR (100 MHz, $\left.\mathrm{CDCl}_{3}\right): \delta 145.2,142.8,138.1,129.2,123.3,99.0,82.4,37.7$, 21.3; IR (thin film) 2963, 1632, 1436, 1262, 1100, $799 \mathrm{~cm}^{-1}$; HRMS (ESI) $\mathrm{m} / z$ calcd for $\mathrm{C}_{12} \mathrm{H}_{15} \mathrm{O}[\mathrm{M}+\mathrm{H}]^{+}:$175.1117, found 175.1113 .

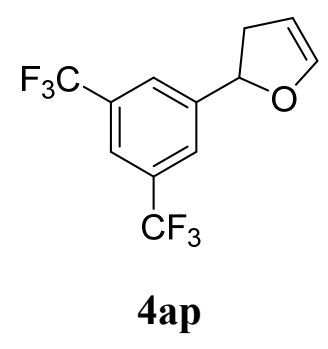

2-(3,5-Bis(trifluoromethyl)phenyl)-2,3-dihydrofuran (4ap), 2,3-Dihydrofuran 1a $(0.15 \mathrm{~mL}, 2.0 \mathrm{mmol})$ and aryliodide $5 \mathrm{p}(170.0 \mathrm{mg}, 0.5 \mathrm{mmol})$ stirring at $120^{\circ} \mathrm{C}$ for 5 h. Purification using medium pressure chromatography (1:15; ethyl acetate: petroleum ether) afforded 4ap. A pale yellow oil, $85.0 \mathrm{mg}, 60 \%$ yield; ${ }^{1} \mathrm{H}$ NMR (400 MHz, 
$\left.\mathrm{CDCl}_{3}\right): \delta 7.80(\mathrm{~s}, 3 \mathrm{H}), 6.49(\mathrm{~d}, J=2.4 \mathrm{~Hz}, 1 \mathrm{H}), 5.65(\mathrm{dd}, J=10.8 \mathrm{~Hz}, 8.0 \mathrm{~Hz}, 1 \mathrm{H})$, $5.00(\mathrm{~d}, J=2.4 \mathrm{~Hz}, 1 \mathrm{H}), 3.24(\mathrm{t}, J=13.2 \mathrm{~Hz}, 1 \mathrm{H}), 2.60-2.54(\mathrm{~m}, 1 \mathrm{H}) ;{ }^{13} \mathrm{C}$ NMR $(100$ $\left.\mathrm{MHz}, \mathrm{CDCl}_{3}\right): \delta 145.8,145.2,132.4(\mathrm{q}, J=32.0 \mathrm{~Hz}), 125.7$ (q, $\left.J=2.9 \mathrm{~Hz}\right), 124.6$ (q, $J=271.2 \mathrm{~Hz}$ ), 121.5 (q, $J=3.6 \mathrm{~Hz}$ ), 99.0, 80.6, 37.9; IR (thin film) 2963, 1625, 1467, 1386, 1281, 1177, 1052, $706 \mathrm{~cm}^{-1}$; HRMS (ESI) $\mathrm{m} / z$ calcd for $\mathrm{C}_{12} \mathrm{H}_{9} \mathrm{~F}_{6} \mathrm{O}[\mathrm{M}+\mathrm{H}]^{+}$: 283.0552, found 283.0554 .<smiles>Cc1cc(C)c(C2CC=CO2)c(C)c1</smiles>

$4 a q$

2-Mesityl-2,3-dihydrofuran (4aq), 2,3-Dihydrofuran 1a $(0.15 \mathrm{~mL}, 2.0 \mathrm{mmol})$ and aryliodide 5q (123.0 mg, $0.5 \mathrm{mmol})$ stirring at $120{ }^{\circ} \mathrm{C}$ for $5 \mathrm{~h}$. Purification using medium pressure chromatography (1:30; ethyl acetate: petroleum ether) afforded 4aq. A pale yellow oil, $60.0 \mathrm{mg}, 63 \%$ yield; ${ }^{1} \mathrm{H}$ NMR (400 MHz, $\left.\mathrm{CDCl}_{3}\right): \delta 6.82(\mathrm{~s}, 2 \mathrm{H})$, $6.38(\mathrm{~s}, 1 \mathrm{H}), 5.87(\mathrm{t}, J=11.6 \mathrm{~Hz}, 1 \mathrm{H}), 5.04(\mathrm{~s}, 1 \mathrm{H}), 2.89(\mathrm{t}, J=13.2 \mathrm{~Hz}, 1 \mathrm{H}), 2.61(\mathrm{t}$, $J=12.4 \mathrm{~Hz}, 1 \mathrm{H}), 2.31(\mathrm{~s}, 6 \mathrm{H}), 2.24(\mathrm{~s}, 3 \mathrm{H}) ;{ }^{13} \mathrm{C} \mathrm{NMR}\left(100 \mathrm{MHz}, \mathrm{CDCl}_{3}\right): \delta 145.3$, 136.9, 136.6, 134.1, 130.3, 129.7, 99.9, 80.1, 35.5, 20.7, 19.9; IR (thin film) 2947, $1617,1459,1377,1259,1134,1052,851 \mathrm{~cm}^{-1}$; HRMS (ESI) $\mathrm{m} / z$ calcd for $\mathrm{C}_{13} \mathrm{H}_{17} \mathrm{O}$ $[\mathrm{M}+\mathrm{H}]^{+}:$189.1274, found 189.1268 .<smiles>CCOC(=O)c1c(N)cccc1C1CC=CO1</smiles>

4ar

Ethyl 2-amino-6-(2,3-dihydrofuran-2-yl)benzoate (4ar), 2,3-Dihydrofuran 1a (0.15 $\mathrm{mL}, 2.0 \mathrm{mmol})$ and aryliodide $5 \mathbf{r}(145.5 \mathrm{mg}, 0.5 \mathrm{mmol})$ stirring at $120{ }^{\circ} \mathrm{C}$ for $5 \mathrm{~h}$. Purification using medium pressure chromatography $(1: 10$; ethyl acetate: petroleum ether) afforded 4ar. A pale yellow oil, $55.0 \mathrm{mg}$, 47\% yield; ${ }^{1} \mathrm{H}$ NMR (500 MHz, $\left.\mathrm{CDCl}_{3}\right): \delta 7.83(\mathrm{~s}, 1 \mathrm{H}), 7.31(\mathrm{~d}, J=8.0 \mathrm{~Hz}, 1 \mathrm{H}), 6.67(\mathrm{~d}, J=9.0 \mathrm{~Hz}, 1 \mathrm{H}), 6.41(\mathrm{~s}, 1 \mathrm{H})$, $5.75(\mathrm{~s}, 2 \mathrm{H}), 5.42(\mathrm{t}, J=9.5 \mathrm{~Hz}, 1 \mathrm{H}), 4.96(\mathrm{~d}, J=1.5 \mathrm{~Hz}, 1 \mathrm{H}), 4.35(\mathrm{q}, J=6.5 \mathrm{~Hz}$, 2H), $3.02(\mathrm{t}, J=13.5 \mathrm{~Hz}, 1 \mathrm{H}), 2.62-2.57(\mathrm{~m}, 1 \mathrm{H}), 1.39(\mathrm{t}, J=7.5 \mathrm{~Hz}, 3 \mathrm{H}) ;{ }^{13} \mathrm{C} \mathrm{NMR}$ 
(100 MHz, $\left.\mathrm{CDCl}_{3}\right): \delta 167.9,150.1,45.1,131.7,130.2,128.7,117.1,110.3,99.1,82.2$ 60.2, 37.2, 14.3; IR (thin film) 3406, 2935, 1688, 1586, 1463, 1204, 1136, 1050, 829 $\mathrm{cm}^{-1}$; HRMS (ESI) $\mathrm{m} / z$ calcd for $\mathrm{C}_{13} \mathrm{H}_{16} \mathrm{NO}_{3}[\mathrm{M}+\mathrm{H}]^{+}: 234.1125$, found 234.1123.

\section{Gram-scale preparation of 3aa and 4aa}

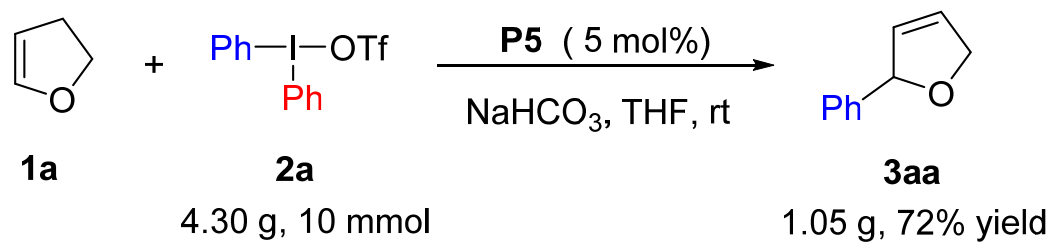

In a $250 \mathrm{~mL}$ Schlenk flask was charged with 2,3-dihydrofuran 1a (40 mmol, 4.0 equiv.), diaryliodonium triflate 2a (10 mmol), P5 (5 mol \%), $\mathrm{NaHCO}_{3}(15 \mathrm{mmol}, 1.5$ equiv.), and THF (60 mL) under $\mathrm{N}_{2}$. The mixture was stirred at room temperature for $48 \mathrm{~h}$ until diaryliodonium triflate $\mathbf{2 a}$ was completely consumed (monitored by TLC). Then, the solvent was removed under the reduced pressure and the crude product was purified by flash column chromatography (the crude residue was dryloaded with silical gel, ethyl acetate/petroleum ether: $1 / 50$ to $1 / 30)$ to afford product 3aa (1.05 g, $72 \%$ yield).

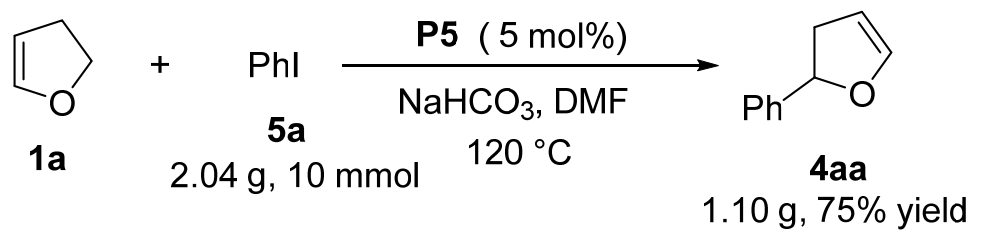

In a $250 \mathrm{~mL}$ Schlenk falsk was charged with 2,3-dihydrofuran 1a (40 mmol, 4.0 equiv.), iodobenzene 5a (10 mmol), P5 (5 mol \%), $\mathrm{NaHCO}_{3}(15 \mathrm{mmol}, 1.5$ equiv.), and DMF $(60 \mathrm{~mL})$ under $\mathrm{N}_{2}$. The reaction mixture was heated to $120^{\circ} \mathrm{C}$ in an oil bath for $8 \mathrm{~h}$. After the completion of the reaction, the solvent was removed under the reduced pressure and the crude product was purified by flash column chromatography (the crude residue was dryloaded with silical gel, 1/50 to 1/30; ethyl acetate/petroleum ether) to afford product $4 \mathbf{a a}(1.10 \mathrm{~g}, 75 \%$ yield). 


\section{Hg-poisoning experiments for P5}

1)<smiles>C1=COCC1</smiles>

1a

2)<smiles>C1=CO[CH+]C1</smiles>

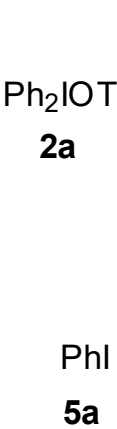

$5 a$
$\mathrm{Hg}(100$ equiv.)

P5 (5 mol\%)

$\mathrm{NaHCO}_{3}$

$$
\text { THF, it }
$$

$\mathrm{Hg}$ (100 equiv.)

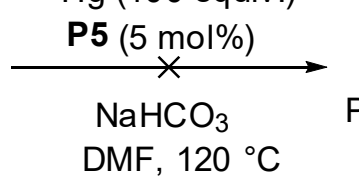

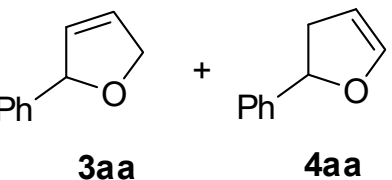

$75 \%(3 \mathbf{a a} / \mathbf{4 a a}=20 / 1)$

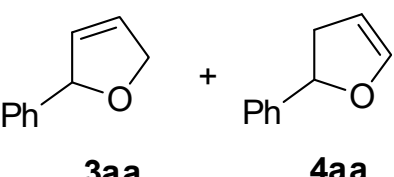

When 100 equiv. of $\mathrm{Hg}$ was added to the diphenyliodonium triflate under optimized conditions, 3aa was still obtained in $75 \%$ yield as the major isomer with high regioselectivity, whereas adding 100 equiv. of $\mathrm{Hg}$ to the iodobenzene-conditions completely inhibited the reaction. These results indicated that the catalytic process with diaryliodonium salt might not involve $\operatorname{Pd}(0)$ species at room temperature but existing $\operatorname{Pd}(0)$ species with aryliodide at high temperature.

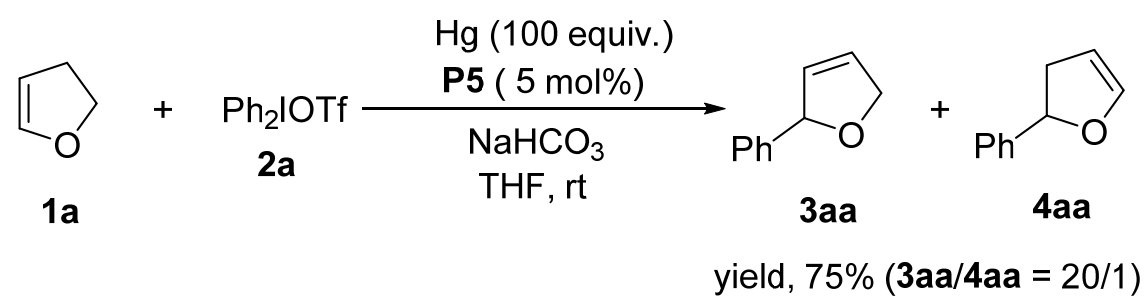

In a $25 \mathrm{~mL}$ Schlenk falsk was charged with compound 1a (2.0 mmol, 4.0 equiv.), 2a (0.5 mmol), P5 (5 mol \%), $\mathrm{NaHCO}_{3}$ (0.75 mmol, 1.5 equiv.), $\mathrm{Hg}$ (100 equiv.), and THF (3 mL) under $\mathrm{N}_{2}$. The mixture was stirred at room temperature for $24 \mathrm{~h}$ until $2 \mathbf{a}$ was completely consumed (monitored by TLC). Then, EtOAc $(10 \mathrm{~mL})$ was added to the residue. The mixture was extracted with EtOAc $(3 \times 10 \mathrm{~mL})$. The combined organic layers were washed with brine $(10 \mathrm{~mL})$, dried over $\mathrm{Na}_{2} \mathrm{SO}_{4}$, and filtration. The solvent was removed under the reduced pressure and the crude product was purified by flash column chromatography (the crude residue was dryloaded with silical gel, 1/50 to 1/30, ethyl acetate/petroleum ether) to afford product 3aa (55 $\mathrm{mg}$, $75 \%$ yield). 


\section{Deuteration experiments and synthesis of compounds D-3ag}

1)

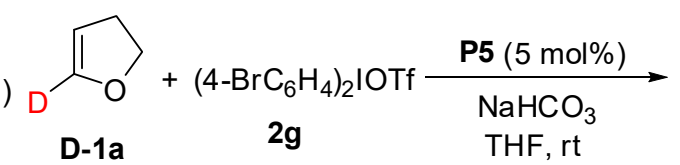<smiles>[2H]C1(c2ccc(Br)cc2)C=CCO1</smiles>

D-3ag, $46 \%$

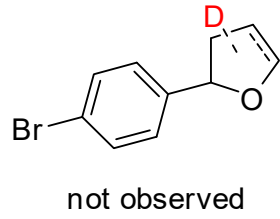

2)

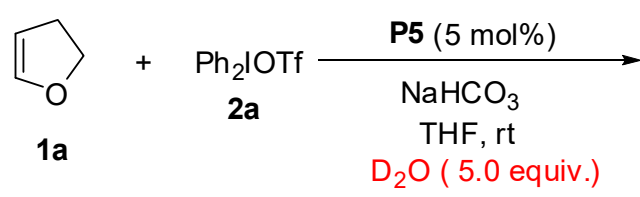

3)

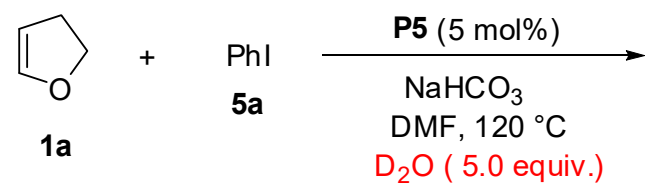<smiles>c1ccc(C23CCC(CC2)O3)cc1</smiles>

D-3aa, not observed<smiles>C1=COC(c2ccccc2)C1</smiles><smiles>[C+]1C=COC1c1ccccc1</smiles>

D-4aa, not observed

Synthesis of D-1a:

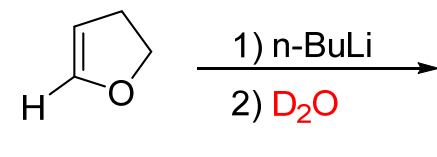

$1 a$<smiles>[2H]C1=CCCO1</smiles>

D-1a, 53\% yield

In a dry $100 \mathrm{~mL}$ two-necked flask, $\mathrm{n}-\mathrm{BuLi}(1.6 \mathrm{M}$ in hexane, $20 \mathrm{~mL}$ ) was added rapidly to a mixture of 2,3-dihydrofuran $(2.0 \mathrm{~mL}, 28 \mathrm{mmol})$ and TMEDA $(0.60 \mathrm{~g})$, whereupon vigorous effervescence and precipitation occurred. The mixture was then cooled $\left(-20^{\circ} \mathrm{C}\right)$ and the addition was completed with stirring. The solid was allowed to settle before the liquid was decanted. The residue was washed with dry hexane $(3 \times 6 \mathrm{ml})$ and dried in vacuo (Caution: highly pyrophoric solid). The solid was subsequently suspended in dry toluene $(2 \mathrm{ml})$ and cooled to $-30{ }^{\circ} \mathrm{C} . \mathrm{D}_{2} \mathrm{O}$ was added dropwise very slowly, and the reaction mixture was allowed to warm to r.t. gradually, The deuterated 2,3-dihydrofuran was obtained in 53\% yield by distillation of the mixture over a distillation column.

(2-D)-2,3-dihydrofuran (D-1a), ${ }^{[13]}$ A colorless oil, 1.05 g, 53\% yield; ${ }^{1} \mathrm{H}$ NMR (600 $\left.\mathrm{MHz}, \mathrm{CDCl}_{3}\right): \delta 4.95(\mathrm{t}, J=2.4 \mathrm{~Hz}, 1 \mathrm{H}), 4.32(\mathrm{t}, J=9.6 \mathrm{~Hz}, 2 \mathrm{H}), 2.62(\mathrm{td}, J=9.6 \mathrm{~Hz}$, $2.4 \mathrm{~Hz}, 2 \mathrm{H}$ ). (Owing to the low boiling point of D-1a, the ${ }^{1} \mathrm{H}$ NMR spectra of D-1a containing a little toluene.) 

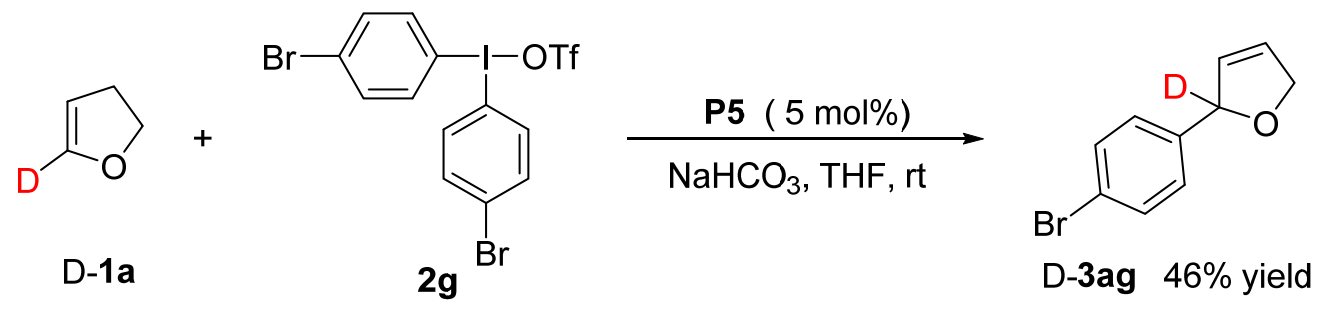

In a $25 \mathrm{~mL}$ Schlenk flask was charged with D-1a (2.0 mmol, 4.0 equiv.), diaryliodonium triflates $2 \mathrm{~g}(0.5 \mathrm{mmol}), \mathrm{P} 5$ (5 mol \%), $\mathrm{NaHCO}_{3}(0.75 \mathrm{mmol}, 1.5$ equiv.), and THF ( $3 \mathrm{~mL})$ under $\mathrm{N}_{2}$. The mixture was stirred at room temperature for $20 \mathrm{~h}$ until diaryliodonium triflate $\mathbf{2 g}$ was completely consumed (monitored by TLC). Then, the solvent was removed under the reduced pressure and the crude product was purified by flash column chromatography (the crude residue was dryloaded with silical gel, ethyl acetate/petroleum ether: $1 / 50$ to $1 / 30$ ) to afford product D-3ag (52 mg, $46 \%$ yield). A yellow oil, ${ }^{1} \mathrm{H}$ NMR (400 MHz, $\left.\mathrm{CDCl}_{3}\right): \delta 7.47(\mathrm{~d}, J=8.4 \mathrm{~Hz}, 2 \mathrm{H})$, $7.18(\mathrm{~d}, J=8.0 \mathrm{~Hz}, 2 \mathrm{H}), 6.05-6.04(\mathrm{~m}, 1 \mathrm{H}), 5.84-5.83(\mathrm{~m}, 1 \mathrm{H}), 4.87-4.84(\mathrm{~m}, 1 \mathrm{H})$, 4.77-4.74 (m, 1H); ${ }^{13} \mathrm{C}$ NMR (100 MHz, $\left.\mathrm{CDCl}_{3}\right): \delta 140.1,131.5,129.4,128.0,127.0$, 121.6, 87.0, 75.8; HRMS (ESI) $\mathrm{m} / z$ calcd for $\mathrm{C}_{10} \mathrm{H}_{9} \mathrm{DBrO}[\mathrm{M}+\mathrm{H}]^{+}:$225.9972, found 225.9974.

\section{Proposed intermediates detected by HRMS (ESI)}

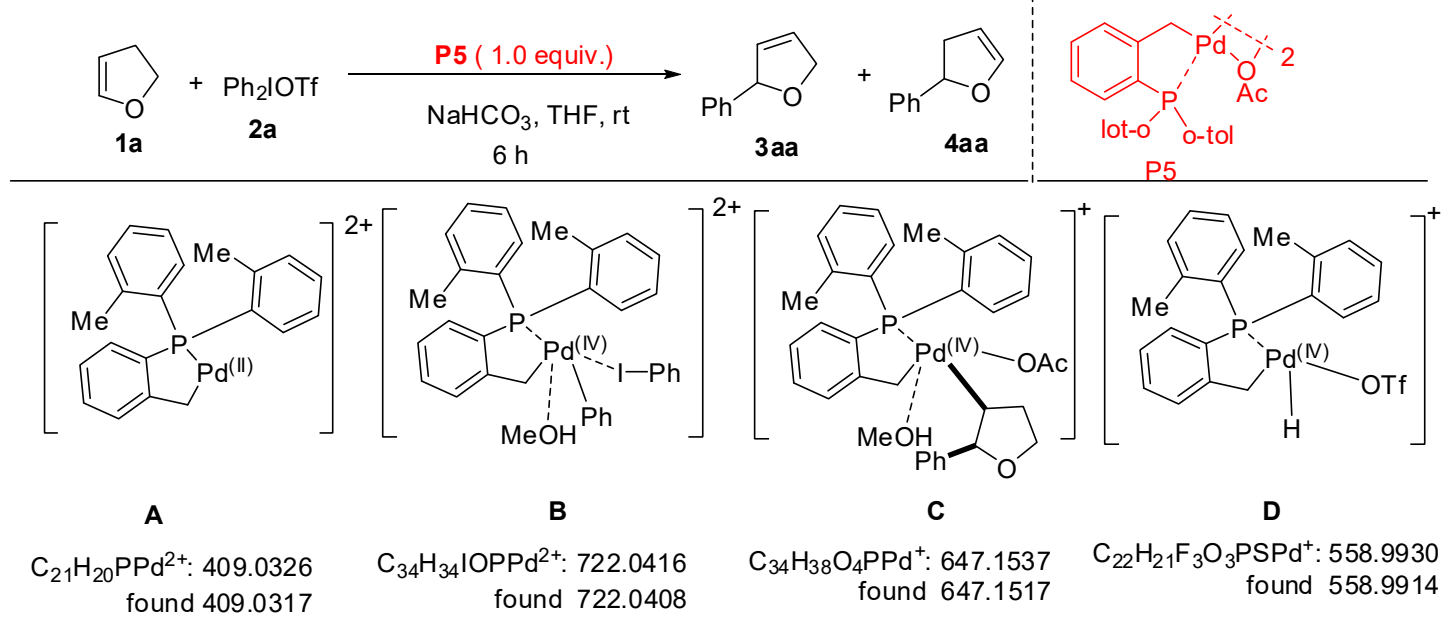

When P5 $(0.1 \mathrm{mmol}), \mathbf{1 a}(0.4 \mathrm{mmol}), \mathbf{2 a}(0.1 \mathrm{mmol}), \mathrm{NaHCO}_{3}(0.1 \mathrm{mmol})$ were mixed in THF for $6 \mathrm{~h}$, the reaction mixture was directly detected by HRMS(ESI, diluted with $\mathrm{MeOH})$. Some of the structures could be detected: 
1) The HRMS for intermediate A. Intermediate $\mathbf{A}$ had a correlation with the catalyst P5, calculated for $\mathrm{C}_{21} \mathrm{H}_{20} \mathrm{PPd}^{2+}$ : 409.0326; found 409.0317.

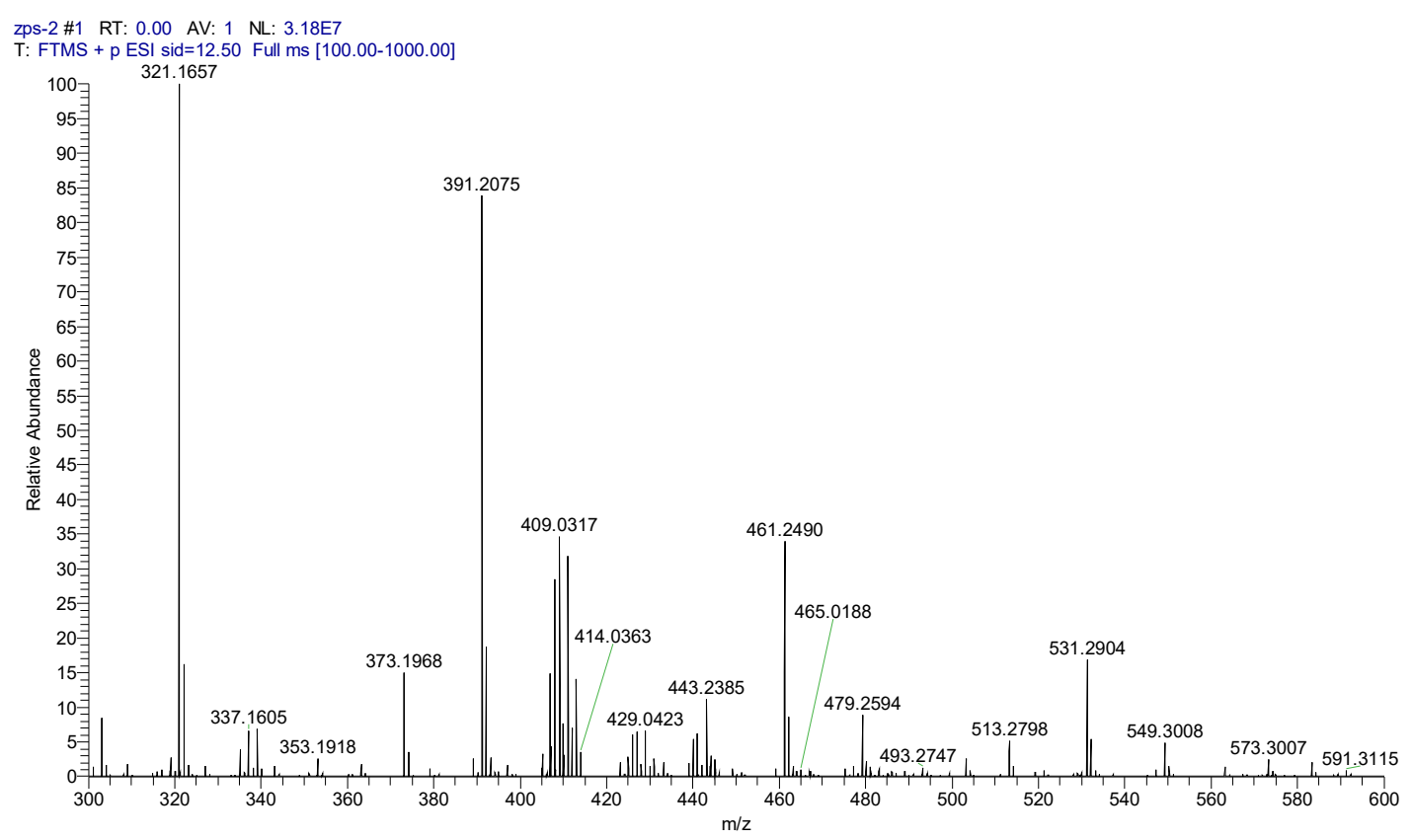

2) The HRMS for intermediate $\mathbf{B}$. Intermediate $\mathbf{B}$ had a correlation with the oxidative addition of 2a to catalyst P5 to form the intermediate Pd-1-2, calculated for $\mathrm{C}_{34} \mathrm{H}_{34} \mathrm{IOPPd}^{2+}$ : 722.0416; found 722.0408.

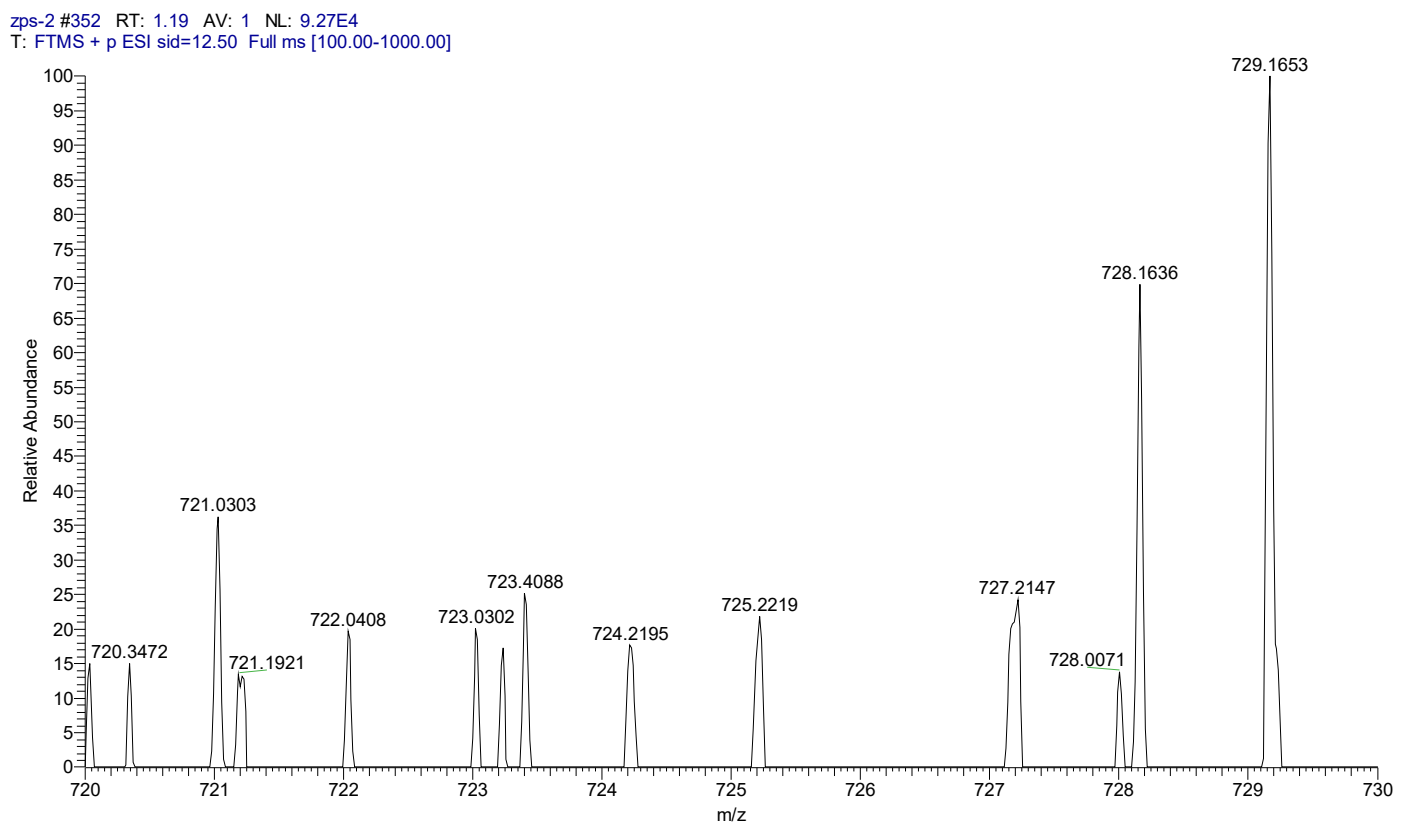


3) The HRMS for intermediate $\mathbf{C}$. Intermediate $\mathbf{C}$ had a correlation with the insertion of Ar-Pd to 1a to form the intermediate Pd-1-5 or $\beta$-elimination intermediate Pd-1-6, However, we can not determined whether it was Pd-1-5 or Pd-1-6 becuase these two intermediates had the same molecular weight. Calculated for $\mathrm{C}_{34} \mathrm{H}_{38} \mathrm{O}_{4} \mathrm{PPd}^{+}: 647.1537$; found 647.1517 .

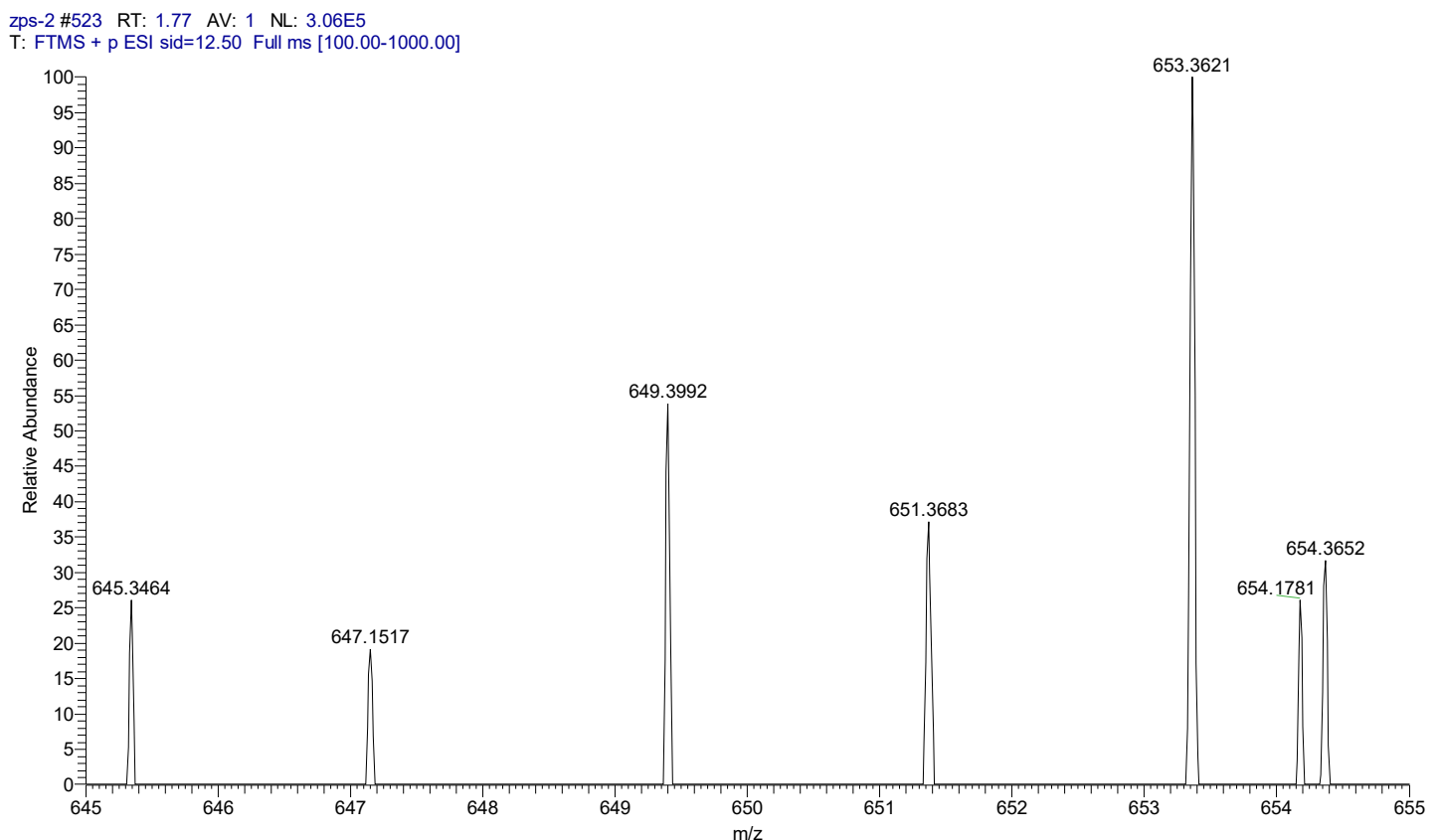

4) The HRMS for intermediate D. Intermediate D had a correlation with $\mathrm{Pd}-\mathrm{H}$ intermediate Pd-1-7. Calculated for $\mathrm{C}_{22} \mathrm{H}_{21} \mathrm{~F}_{3} \mathrm{O}_{3} \mathrm{PSPd}^{+}$: 558.9930; found 558.9914.

zps-2 \#385 RT: $1.30 \quad$ AV: 1 NL: $2.09 E 5$

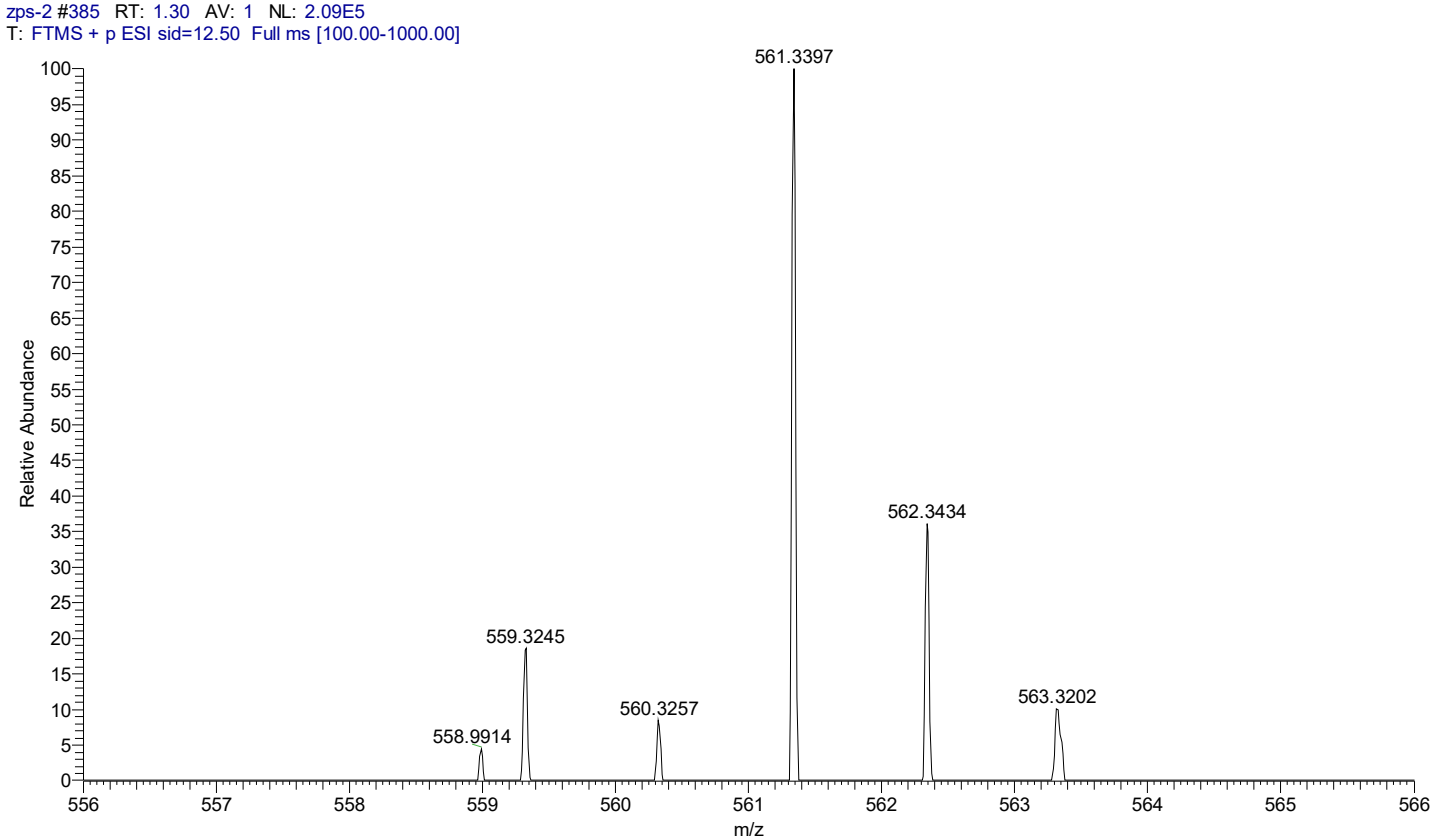




\section{Other alkenes tested and synthesis of compound 7}

We have tested some other types of alkenes with the P5-catalyzed optimal conditions. Allylbenzene 6a reacted with 2a providing the desired product 7aa in $94 \%$ yield while 6a reacting with $\mathbf{2 c}$ afforded product $7 \mathbf{a c}$ and $\mathbf{7 a c}$ ' in 98\% yield with a 3:1 ratio. These results indicated that the reaction show a regioselective $\beta-\mathrm{H}$ elimination. The substituent had an impact on the regioselctivity of $\beta-\mathrm{H}$ elimination at the benzyl position. Other types of alkenes, such as cyclohexene, norborene, activated akenes, etc., were also tested but no desired Heck products were observed. The results are listed below:

1)

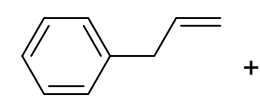

$6 a$

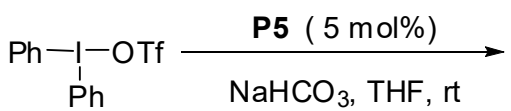

2a<smiles>C(=C/c1ccccc1)\Cc1ccccc1</smiles>

7aa, $94 \%$ yield

2)

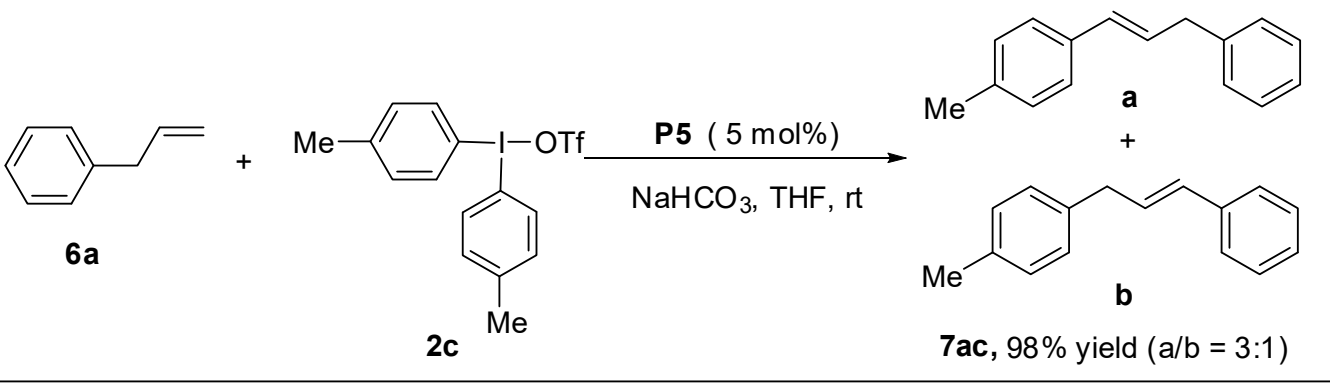

Some other unsuccessful alkenes tested:<smiles>C1=CCCCC1</smiles><smiles>C1=CC2CCC1C2</smiles><smiles>C1=CC2OC1Oc1ccccc12</smiles><smiles>COCC=Cc1ccccc1</smiles>
$\mathrm{C}^{\mathrm{N}}$<smiles>O=[N+]([O-])/C=C/c1ccccc1</smiles>

Synthesis of compound 7:

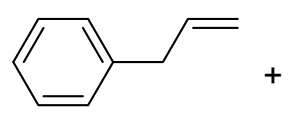

$6 a$

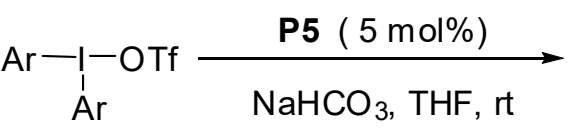

2<smiles>BrC/C=C/c1ccccc1</smiles>

7

In a $25 \mathrm{~mL}$ Schlenk flask was charged with allylbenzene (2.0 mmol, 4.0 equiv.), diaryliodonium triflates 2 ( $0.5 \mathrm{mmol}), \mathrm{P} 5$ (5 mol \%), $\mathrm{NaHCO}_{3}(0.75 \mathrm{mmol}, 1.5$ equiv.), and THF ( $3 \mathrm{~mL}$ ) under $\mathrm{N}_{2}$. The mixture was stirred at room temperature for $20 \mathrm{~h}$ until diaryliodonium triflate 2 was completely consumed (monitored by TLC). Then, the solvent was removed under the reduced pressure and the crude product was purified 
by flash column chromatography (the crude residue was dryloaded with silical gel, ethyl acetate/petroleum ether: $1 / 50$ to $1 / 30$ ) to afford products 7 .

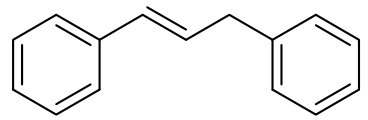

$7 \mathbf{a a}$

(E)-Prop-1-ene-1,3-diyldibenzene (7aa), ${ }^{[14 \mathrm{a}]}$ A pale yellow oil, $92.0 \mathrm{mg}, 94 \%$ yield; ${ }^{1} \mathrm{H}$ NMR (400 MHz, $\left.\mathrm{CDCl}_{3}\right): \delta 7.36-7.28(\mathrm{~m}, 5 \mathrm{H}), 7.24-7.17(\mathrm{~m}, 5 \mathrm{H}), 6.47(\mathrm{~d}, J=$ $11.6 \mathrm{~Hz}, 1 \mathrm{H}), 6.38(\mathrm{q}, J=6.8 \mathrm{~Hz}, 1 \mathrm{H}), 3.55(\mathrm{~d}, J=6.4 \mathrm{~Hz}, 2 \mathrm{H}) ;{ }^{13} \mathrm{C}$ NMR $(100 \mathrm{MHz}$, $\left.\mathrm{CDCl}_{3}\right): \delta 140.1,137.4,131.0,129.1,128.6,128.4,127.0,126.1,126.0,39.3$.

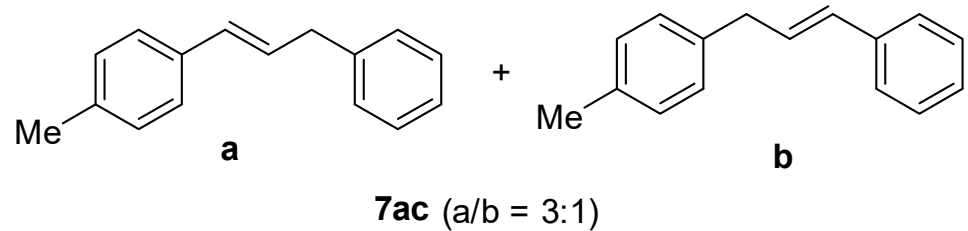

Substituted styrene 7ac. ${ }^{[14 \mathrm{~b}]}$ A pale yellow oil, $101.9 \mathrm{mg}$, 98\% yield; major isomer: ${ }^{1} \mathrm{H}$ NMR (400 MHz, $\left.\mathrm{CDCl}_{3}\right): \delta 7.35-7.18(\mathrm{~m}, 7 \mathrm{H}), 7.12-7.07(\mathrm{~m}, 2 \mathrm{H}), 6.45-5.39(\mathrm{~m}$, 1H), 6.37-5.25 (m, 1H), $3.52(\mathrm{dd}, J=6.8,1.3 \mathrm{~Hz}, 2 \mathrm{H}), 2.30(\mathrm{~s}, 3 \mathrm{H}) ;{ }^{13} \mathrm{C}$ NMR $(100$ $\left.\mathrm{MHz}, \mathrm{CDCl}_{3}\right) \delta 140.3,136.8,134.7,130.9,128.6,128.4,128.1,126.1,126.0,39.3$, 21.1. minor isomer: ${ }^{1} \mathrm{H}$ NMR $\left(400 \mathrm{MHz}, \mathrm{CDCl}_{3}\right): \delta 7.35-7.18(\mathrm{~m}, 7 \mathrm{H}), 7.12-7.07(\mathrm{~m}$, 2H), 6.45-5.39 (m, 1H), 6.37-5.25 (m, 1H), $3.49(\mathrm{dd}, J=6.6,1.1 \mathrm{~Hz}, 2 \mathrm{H}), 2.32(\mathrm{~s}$, $3 \mathrm{H}) ;{ }^{13} \mathrm{C}$ NMR $\left(100 \mathrm{MHz}, \mathrm{CDCl}_{3}\right) \delta 137.5,137.0,135.7,130.8,129.5,129.2,128.5$, $128.5,127.0,126.1,38.9,21.0$.

\section{DFT calculations for $P d(I I) / P d(I V)$ and $P d(0) / P d(I I)$ cycle}

\subsection{Computational Details}

All calculations were performed using Gaussian 16 program Rev. A.03. ${ }^{[15]}$ Geometry optimizations were carried out with M06-L $\mathrm{L}^{[16]} / \mathrm{def} 2-\mathrm{SVP}^{[17]}$ level of theory. Frequency analysis calculations were performed to characterize the structures to be the minima (no imaginary frequency) or transition states (one imaginary frequency). Transition states were verified by intrinsic reaction coordinate (IRC) calculations. At M06-L/def2-SVP geometries, the free energy results were further refined by 
calculating the single point energy at M06-L/def2-TZVP ${ }^{[17]}$ level. The solvation effect of THF was simulated by the $\mathrm{SMD}^{[18]}$ continuum solvent mode. Accurate prediction of the entropies in solution is still a challenge for computational chemistry. Yu et al have demonstrated that the ideal gas-phase model overestimated entropic contributions by $50-60 \%$ in their addition reactions. ${ }^{[19]}$ Therefore, a scaling factor of 0.5 to the gas-phase entropic contributions is applied as a rough estimate. The $3 \mathrm{D}$ optimized structure figures in this paper were displayed by CYLview visualization program. ${ }^{[20]}$ Additional computational information and the Cartesian coordinates of the optimized structure are given in the supporting information.

10.2 The absolute energies of all optimized structures.

Table S1. The absolute energies of all optimized structures

\begin{tabular}{|c|c|c|c|c|c|c|}
\hline Species & $\begin{array}{c}\text { Hc } \\
\text { hartree }\end{array}$ & $\begin{array}{c}\text { Gc } \\
\text { hartree }\end{array}$ & $\begin{array}{c}\text { H } \\
\text { hartree }\end{array}$ & $\begin{array}{c}\text { G } \\
\text { hartree }\end{array}$ & $\begin{array}{c}\text { Esp }+ \text { Sol } \\
\text { hartree }\end{array}$ & $\begin{array}{c}\mathbf{G}_{\mathrm{sol}} \\
\text { hartree }\end{array}$ \\
\hline PhOTf & 0.133147 & 0.080531 & -1192.113 & -1192.165 & -1193.3505 & -1193.27 \\
\hline 2,3-dihydrofuran & 0.098292 & 0.064664 & -230.9197 & -230.9533 & -231.27946 & -231.2148 \\
\hline 2-phenyl-2,3-dihydrofuran & 0.183668 & 0.138885 & -461.6966 & -461.7414 & -462.38429 & -462.2454 \\
\hline 2-phenyl-2,5-dihydrofuran & 0.18345 & 0.139101 & -461.691 & -461.7354 & -462.37977 & -462.24066 \\
\hline $\mathrm{TfOH}$ & 0.047995 & 0.006498 & -961.3478 & -961.3893 & -962.2603 & -962.2538 \\
\hline $\mathrm{AcO}^{-}$ & 0.053499 & 0.020325 & -228.2537 & -228.2869 & -228.66007 & -228.63975 \\
\hline $\mathrm{PhI}$ & 0.096724 & 0.058091 & -529.217 & -529.2557 & -529.57455 & -529.51646 \\
\hline $\mathrm{Ph}_{2} \mathrm{IOTf}$ & 0.230655 & 0.157454 & -1721.283 & -1721.356 & -1722.9038 & -1722.7463 \\
\hline $\mathrm{TfO}^{-}$ & 0.035627 & -0.00496 & -960.8538 & -960.8944 & -961.82695 & -961.83191 \\
\hline Pd-1-1 & 0.426354 & 0.341662 & -1508.756 & -1508.84 & -1510.465 & -1510.1234 \\
\hline Pd-1-TS1 & 0.657253 & 0.522772 & -3230.04 & -3230.174 & -3233.3493 & -3232.8265 \\
\hline $\mathrm{Pd}-1-2$ & 0.660545 & 0.529227 & -3230.083 & -3230.214 & -3233.3981 & -3232.8689 \\
\hline Pd-1-3 & 0.624863 & 0.522664 & -1970.812 & -1970.914 & -1973.2626 & -1972.74 \\
\hline Pd-1-TS2 & 0.623232 & 0.521126 & -1970.784 & -1970.886 & -1973.231 & -1972.7099 \\
\hline Pd-1-4 & 0.625125 & 0.522155 & -1970.813 & -1970.916 & -1973.258 & -1972.7358 \\
\hline Pd-1-5 & 0.62302 & 0.517763 & -1970.804 & -1970.909 & -1973.2532 & -1972.7354 \\
\hline Pd-1-TS3 & 0.619368 & 0.514637 & -1970.794 & -1970.899 & -1973.2411 & -1972.7265 \\
\hline Pd-1-6 & 0.621203 & 0.516056 & -1970.807 & -1970.912 & -1973.2571 & -1972.741 \\
\hline Pd-1-7 & 0.47358 & 0.370871 & -2470.102 & -2470.205 & -2472.7206 & -2472.3497 \\
\hline Pd-1-TS4 & 0.471139 & 0.369238 & -2470.094 & -2470.196 & -2472.7059 & -2472.3367 \\
\hline Pd-1-8 & 0.621544 & 0.514787 & -1970.804 & -1970.911 & -1973.2544 & -1972.7397 \\
\hline Pd-1-TS5 & 0.620015 & 0.516054 & -1970.794 & -1970.898 & -1973.2425 & -1972.7265 \\
\hline
\end{tabular}




\begin{tabular}{ccccccc} 
Pd-1-9 & 0.622922 & 0.517805 & -1970.798 & -1970.903 & -1973.2493 & -1972.7315 \\
Pd-1-10 & 0.624771 & 0.520337 & -1970.811 & -1970.916 & -1973.2643 & -1972.7439 \\
Pd-1-TS6 & 0.619273 & 0.512702 & -1970.809 & -1970.916 & -1973.258 & -1972.7453 \\
Pd-1-11 & 0.622161 & 0.515459 & -1970.807 & -1970.914 & -1973.2583 & -1972.7428 \\
Pd-2-1 & 0.579214 & 0.474185 & -2041.261 & -2041.366 & -2043.373 & -2042.899 \\
Pd-2-TS1 & 0.5784 & 0.47392 & -2041.248 & -2041.352 & -2043.358 & -2042.884 \\
Pd-2-2 & 0.580876 & 0.477206 & -2041.273 & -2041.376 & -2043.392 & -2042.915 \\
Pd-2-TS2 & 0.579458 & 0.478908 & -2041.26 & -2041.361 & -2043.379 & -2042.9 \\
Pd-2-3 & 0.582639 & 0.483676 & -2041.3 & -2041.399 & -2043.419 & -2042.935 \\
Pd-2-4 & 0.580644 & 0.478023 & -2041.296 & -2041.398 & -2043.413 & -2042.935 \\
Pd-2-TS3 & 0.576516 & 0.473858 & -2041.284 & -2041.387 & -2043.398 & -2042.924 \\
Pd-2-5 & 0.578038 & 0.475152 & -2041.285 & -2041.388 & -2043.401 & -2042.926 \\
Pd-2-6 & 0.5771 & 0.471163 & -2041.289 & -2041.395 & -2043.396 & -2042.925 \\
Pd-2-TS4 & 0.576692 & 0.474052 & -2041.288 & -2041.391 & -2043.397 & -2042.923 \\
\hline Pd-2-7 & 0.580928 & 0.479135 & -2041.309 & -2041.411 & -2043.428 & -2042.949 \\
Pd-2-TS5 & 0.577009 & 0.475508 & -2041.295 & -2041.397 & -2043.407 & -2042.931 \\
Pd-2-8 & 0.577585 & 0.474252 & -2041.296 & -2041.399 & -2043.408 & -2042.933 \\
Pd-2-TS6 & 0.575153 & 0.469381 & -2041.281 & -2041.387 & -2043.385 & -2042.916 \\
Pd-2-9 & 0.577043 & 0.472535 & -2041.281 & -2041.386 & -2043.387 & -2042.915 \\
Pd-2-TS7 & 0.575647 & 0.470315 & -2041.276 & -2041.382 & -2043.381 & -2042.911 \\
Pd-2-10 & 0.5759 & 0.473257 & -2041.279 & -2041.382 & -2043.385 & -2042.911 \\
\hline PH & 0.936 &
\end{tabular}

- The $\mathbf{H}_{\mathbf{C}}$ and $\mathbf{G}_{\mathbf{C}}$ designate the thermal correction Enthalpy and Gibbs Free Energy.

- The H(gas) and $\mathbf{G ( g a s )}$ designate Enthalpy and Gibbs Free Energy in gas phase at M06-L/def2-SVP level.

- $\mathbf{E}_{\mathbf{S P}}$ designates the single point energy at M06-L/def2-TZVP level. $\mathbf{G}_{\mathbf{S O L}}$ designates the solvation free energy calculated by SMD continuum solvent mode. The $\mathbf{E}_{\mathbf{S P}}+\mathbf{G}_{\text {SOL }}$ designates the sum of single point energy at M06-L/def2-TZVP level and the solvation free energy.

The Final $\mathrm{G}$ designates the sum of $\mathbf{E}_{\mathbf{S P}}+\mathbf{G}_{\mathbf{S O L}}$ and $\mathbf{G}_{\mathbf{C}}$.

\subsection{The mechanism details.}




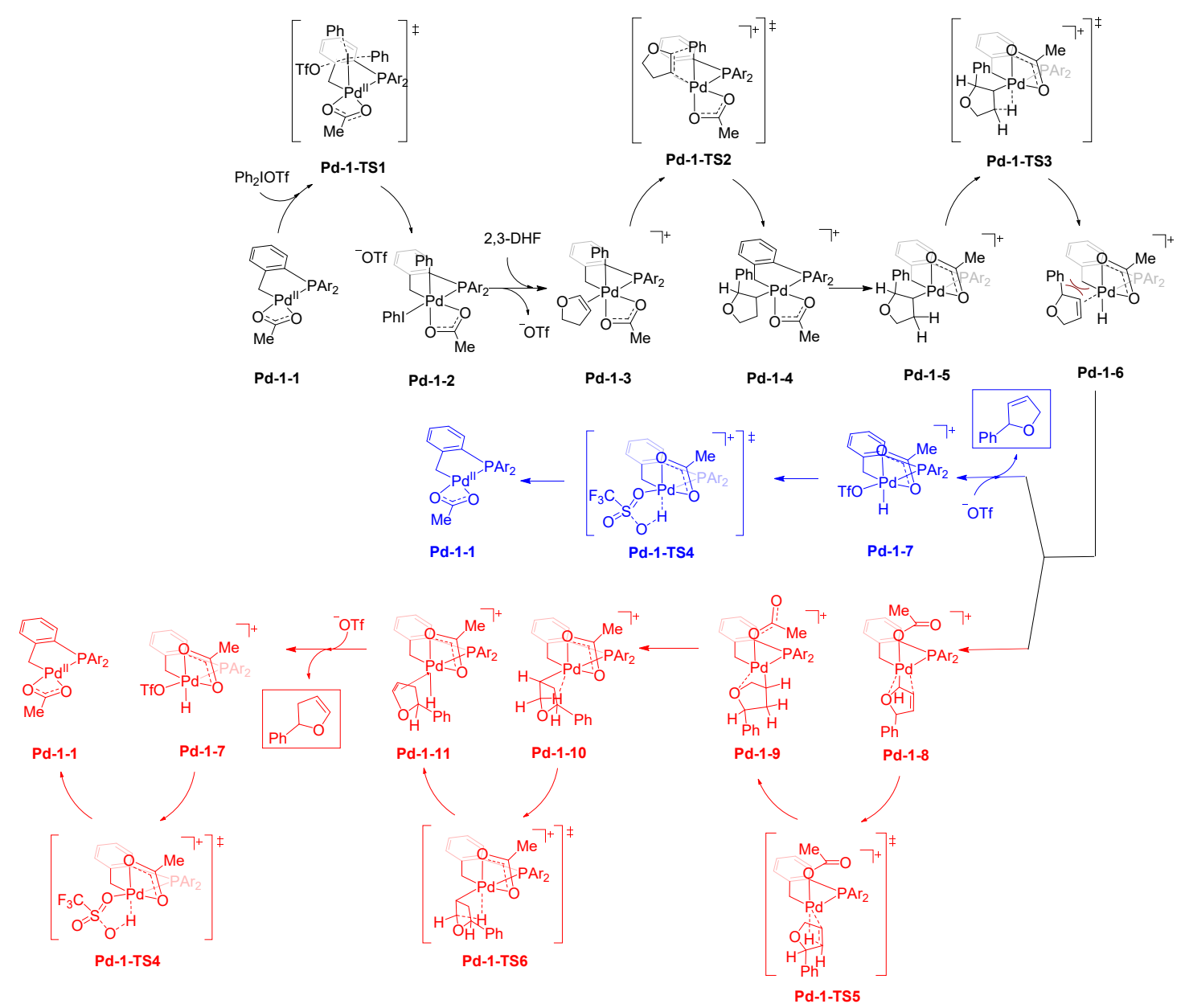

Figure S1. The intermediates and transition states of $\operatorname{Pd}(\mathrm{II}) / \mathrm{Pd}(\mathrm{IV})$ catalytic cycle. 


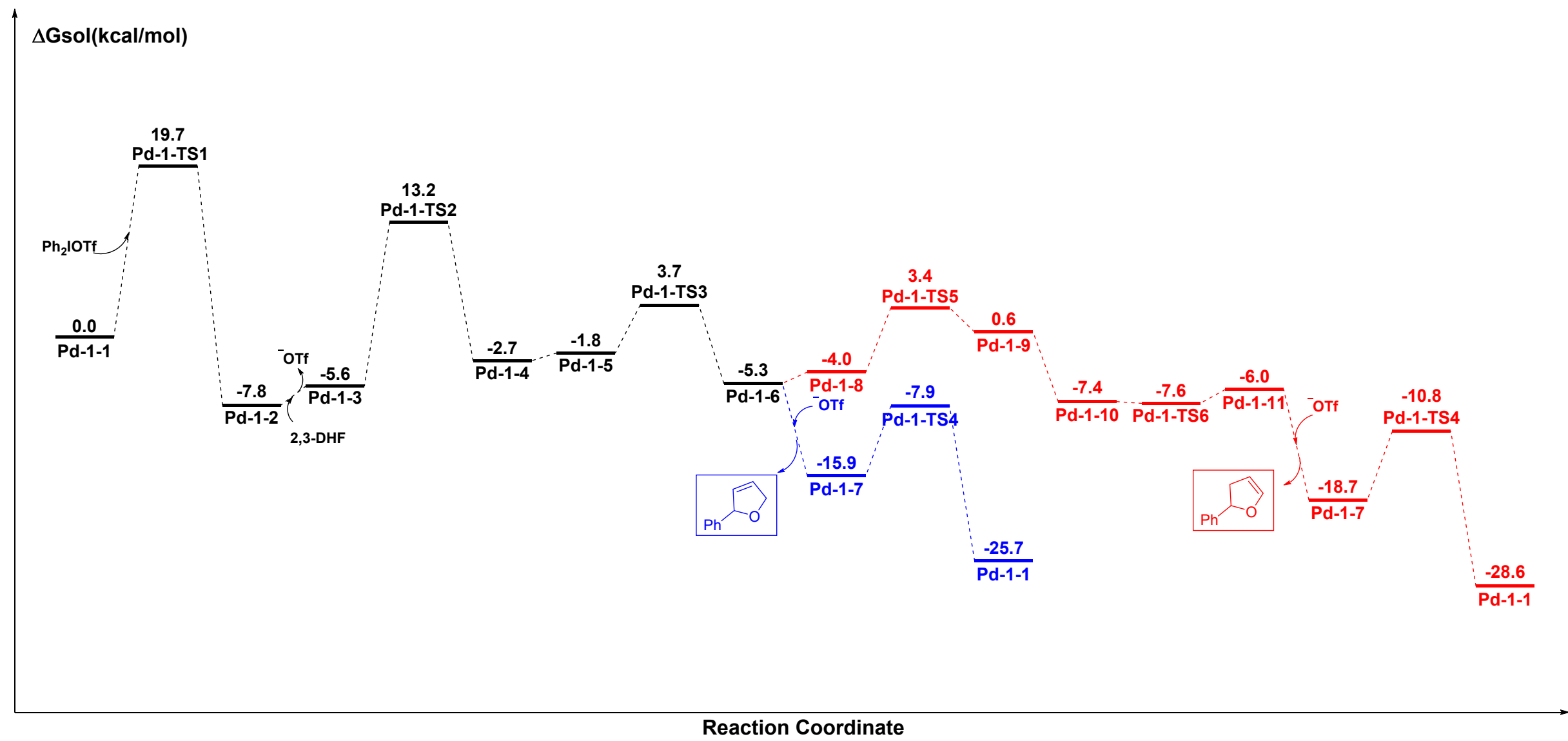

Figure S2. DFT calculated free energy diagram for Pd(II)/Pd(IV) cycle. The energies are given kcal/mol. 


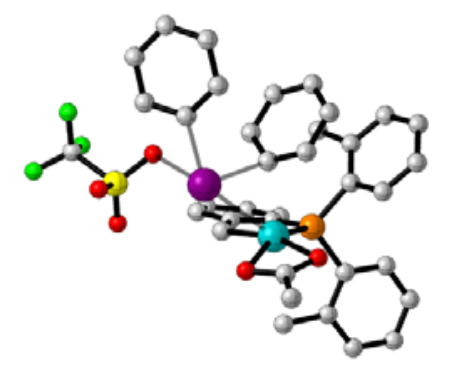

Pd-1-TS1

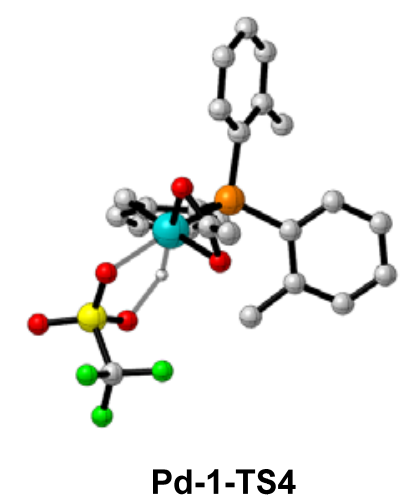

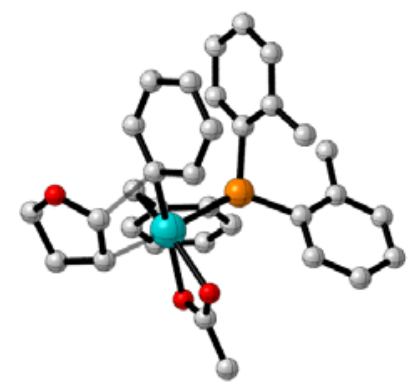

Pd-1-TS2

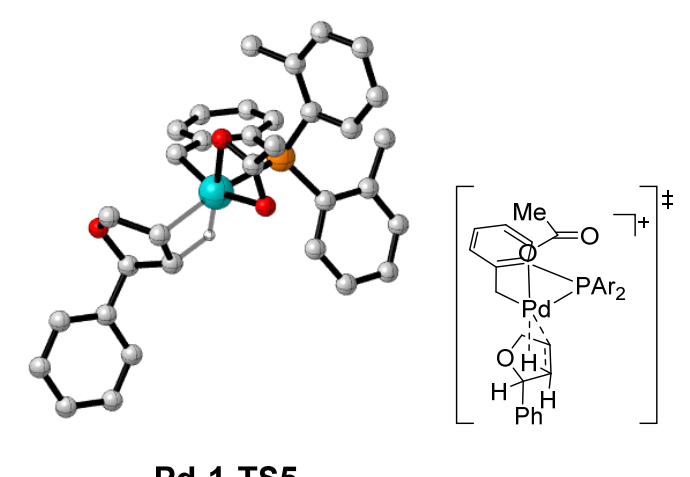

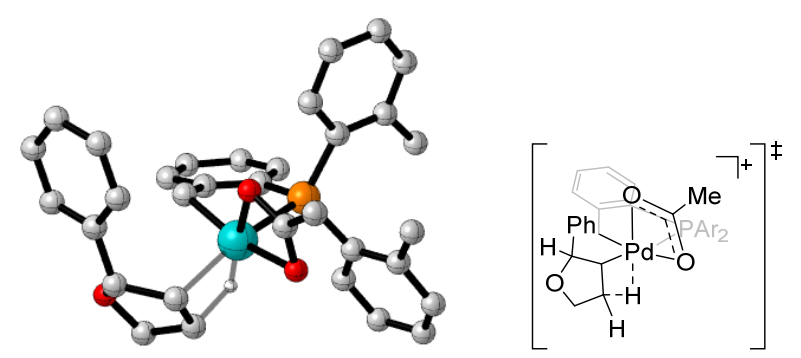

Pd-1-TS3

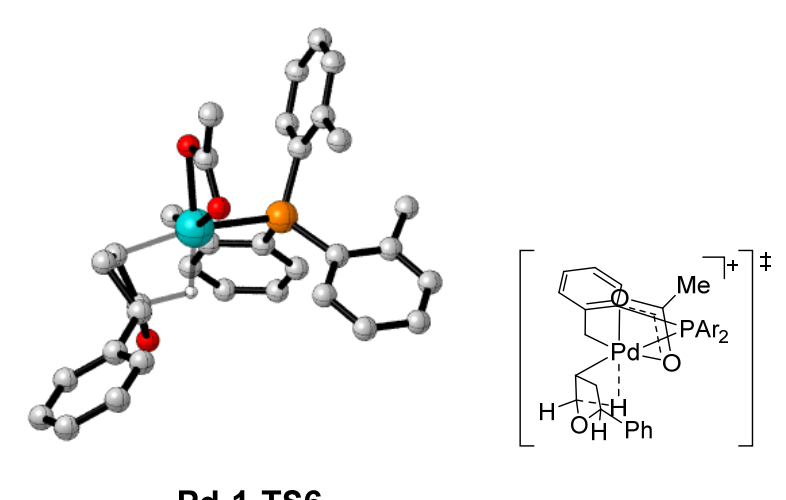

Figure S3. The optimized structure of important transition states. 
As for the $\mathrm{Pd}(0) / \mathrm{Pd}(\mathrm{II})$ mechanism, the oxidative addition via Pd-2-TS1 is $8.8 \mathrm{kcal} / \mathrm{mol}$, the free energy barrier of coupling reaction via $\mathbf{P d - 2 - T S 2}$ is $8.0 \mathrm{kcal} / \mathrm{mol}(\mathbf{P d - 2 - 2} \rightarrow \mathbf{P d - 2}-\mathbf{T S 2})$ and leads to a thermodynamic sink $(\mathbf{P d - 2}-3)$ in the potential energy surface. The $\beta$-hydride elimination via Pd-2-TS3 yields Pd-2-5, which can isomerize to Pd-2-6 to undergo the reduction elimination reaction to produce product A or further undergo $\beta$-hydride insertion and elimination mechanism to generate the product $\mathbf{B}$. The reduction elimination via Pd-2-TS7 is 8.6 $\mathrm{kcal} / \mathrm{mol}(\mathbf{P d - 2 - 6} \rightarrow \mathbf{P d - 2}-\mathbf{T S} 7)$ in free activation energy. However, the following hydride re-insertion via Pd-2-TS4 is almost a barrierless process $\left(\mathrm{D} G^{\neq}=0.5 \mathrm{kcal} / \mathrm{mol}\right)$, which leads to the thermodynamic sink Pd-2-7. Therefore, the hydride re-insertion becomes an irreversible process. Subsequently, the $\beta$-hydride elimination via Pd-2-TS5 furnishes Pd-2-8, which undergoes the reductive elimination $\left(\mathbf{P d - 2 - 7} \rightarrow \mathbf{P d - 2}-\mathbf{T S 6}\right.$ : $\left.\mathrm{D} G^{\neq}=21.7\right)$ With a ligand change reaction from Pd-2-9 to $\mathbf{P d - 2 - 1}$, the catalytic cycle completes and the active species Pd-2-1 is regenerated.

The opposite regioselectivity of $\mathrm{Pd}(0) / \mathrm{Pd}(\mathrm{II})$ cycle compared with $\mathrm{Pd}(\mathrm{II}) / \mathrm{Pd}(\mathrm{IV})$ mechanism can be attributed to the less steric interaction between 2-phenyl-2,5-dihydrofuran and the ligand in the $\mathrm{Pd}(\mathrm{II})$ complex, which increases the $\pi$ backbonding between the $\mathrm{C}=\mathrm{C}$ anti-bonding orbital in 2-phenyl-2,5-dihydrofuran and the $\mathrm{d}$ orbital of $\mathrm{Pd}(\mathrm{II})$ center. Further confirmation of the optimized structure, the bond length of $\mathrm{C}=\mathrm{C}$ in 2-phenyl-2,5-dihydrofuran are $1.35 \AA$ and $1.39 \AA$, for Pd-1-6 and Pd-2-6, correspondingly. Therefore, the bond order of C=C in 2-phenyl-2,5-dihydrofuran is decreased and the hydride re-insertion to the $\mathrm{C}=\mathrm{C}$ in 2-phenyl-2,5-dihydrofuran becomes more feasible in $\operatorname{Pd}(0) / \mathrm{Pd}(\mathrm{II})$ cycle. 


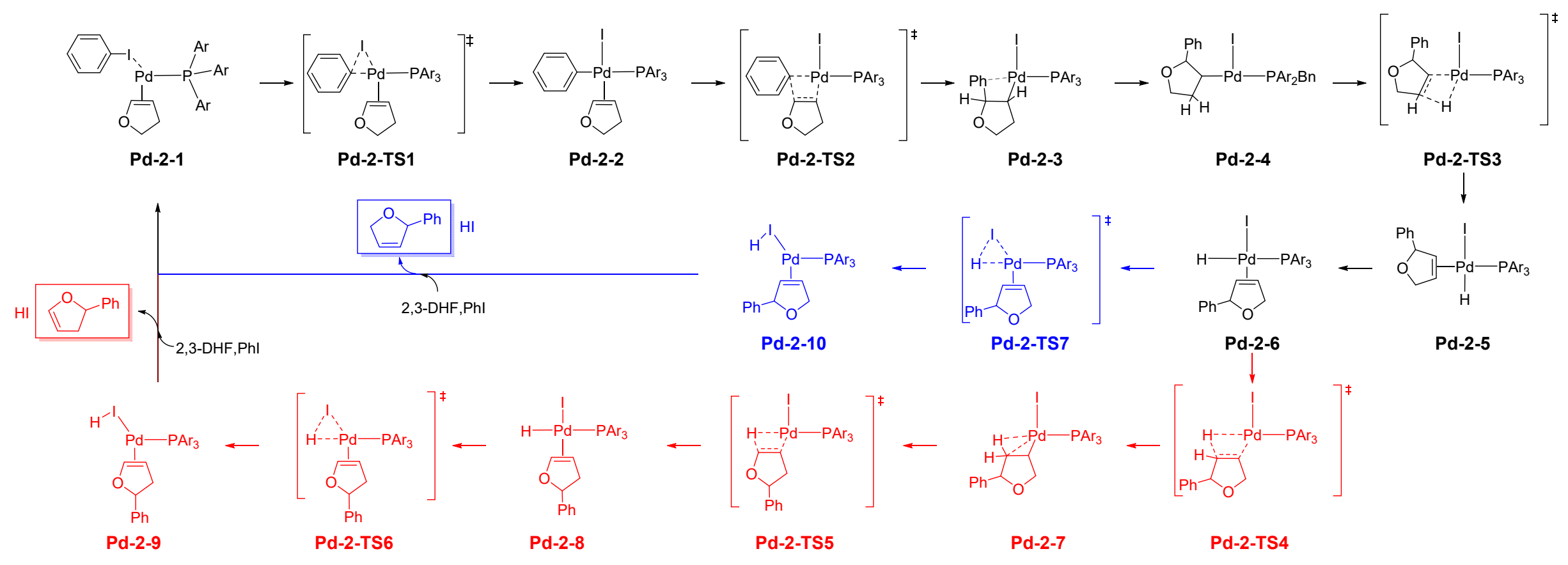

Figure S4. The intermediates and transition states of $\operatorname{Pd}(0) / \mathrm{Pd}(\mathrm{II})$ catalytic cycle. 


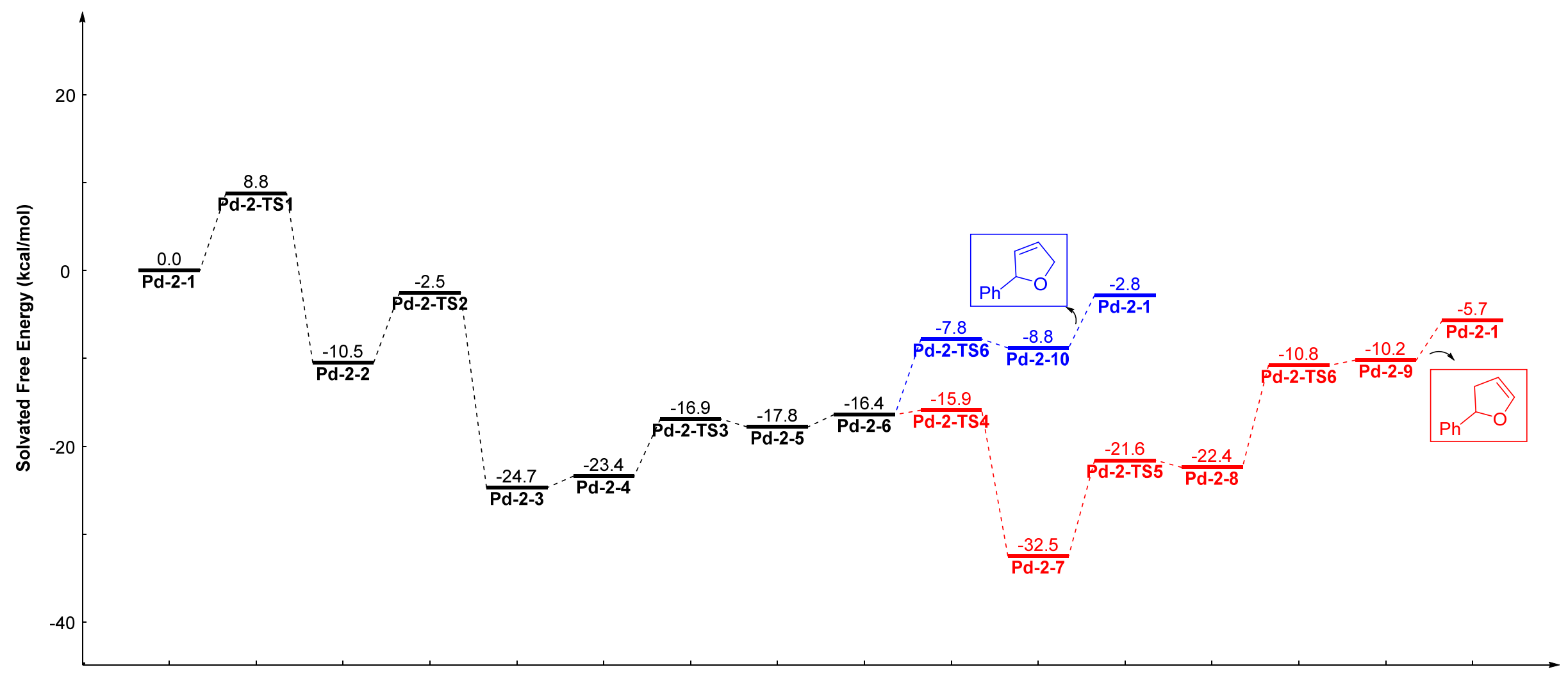

Figure S5. DFT calculated free energy diagram for $\mathrm{Pd}(0) / \mathrm{Pd}(\mathrm{II})$ cycle. The energies are given $\mathrm{kcal} / \mathrm{mol}$. 


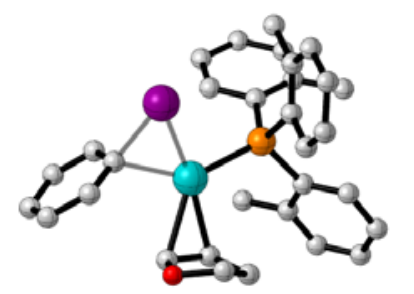

Pd-2-TS1

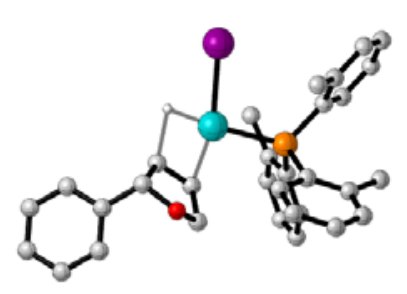

Pd-2-TS4

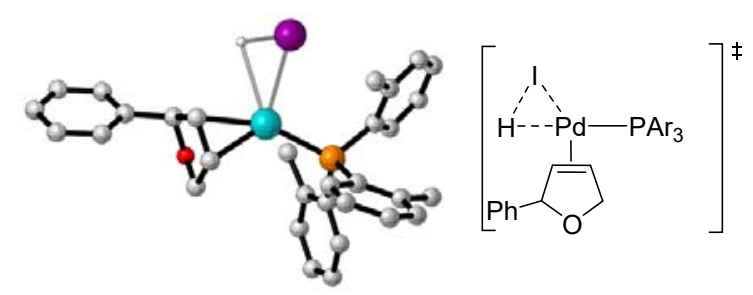

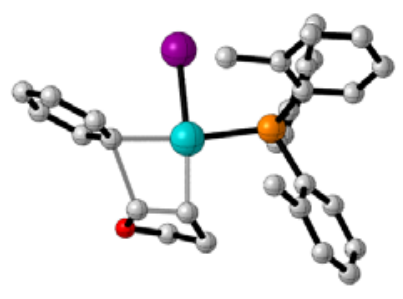

Pd-2-TS2

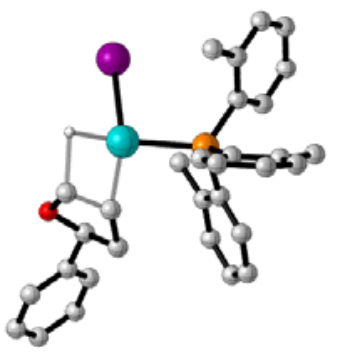

Pd-2-TS5

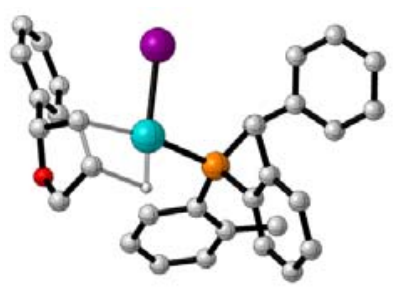

$[\underbrace{\mathrm{Ph}}_{\mathrm{H}_{i}^{\prime}-\mathrm{H}^{\prime}}]^{\prime}$

Pd-2-TS3
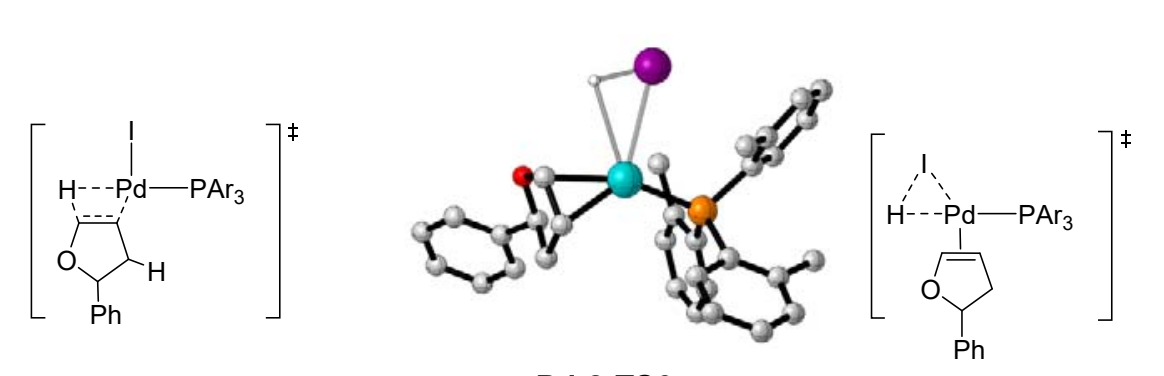

Pd-2-TS6

Pd-2-TS7

Figure S6. The optimized structure of important transition states of $\mathrm{Pd}(0) / \mathrm{Pd}(\mathrm{II})$ cycle. 


\subsubsection{The Cartesian coordinates (xyz) for all optimized structures}

$\begin{array}{cr}2,3 \text {-dihydrofuran } \\ 6 & -1.19775400 \\ 8 & -0.41438300 \\ 6 & 0.95190600 \\ 6 & 0.92672600 \\ 6 & -0.54438200 \\ 1 & 1.51301700 \\ 1 & 1.37075400 \\ 1 & 1.38391100 \\ 1 & 1.49579400 \\ 1 & -2.26832200 \\ 1 & -0.99906500\end{array}$

2-phenyl-2,3-dihydrofuran

\begin{tabular}{|c|c|c|}
\hline 6 & 0.99952200 & 0.31900500 \\
\hline 8 & 1.70122800 & -0.94041000 \\
\hline 6 & 2.88035300 & -0.78098600 \\
\hline 6 & 3.02612100 & 0.38514100 \\
\hline 6 & 1.76009800 & 1.16762800 \\
\hline 1 & 3.55609200 & -1.63283000 \\
\hline 1 & 3.88363300 & 0.68052400 \\
\hline 1 & 1.91287800 & 2.19915300 \\
\hline 1 & 1.10352300 & 0.78901800 \\
\hline 1 & 1.19688700 & 1.25112600 \\
\hline 6 & -0.45834700 & 0.10544100 \\
\hline 6 & -1.33142400 & 1.19841400 \\
\hline 6 & -0.96695900 & -1.14508100 \\
\hline 6 & -2.68505400 & 1.04593200 \\
\hline 1 & -0.94377300 & 2.18135000 \\
\hline 6 & -2.32422900 & -1.29753600 \\
\hline 1 & -0.28746100 & -1.99796000 \\
\hline 6 & -3.18645300 & -0.20554800 \\
\hline 1 & -3.35393300 & 1.90783000 \\
\hline 1 & -2.71037000 & -2.28157700 \\
\hline 1 & -4.24908100 & -0.32781300 \\
\hline
\end{tabular}

2-phenyl-2,5-dihydrofuran

$\begin{array}{rrr}6 & 0.98551200 & 0.60777100 \\ 8 & 1.73404500 & -0.49362700 \\ 6 & 2.86826500 & -0.73713300\end{array}$

-0.00431600
0.03910100
-0.04021200
0.03564200
-0.02807400
0.77559700
-0.98990600
0.96570700
-0.78767900
-0.00697200
-0.04780100

0.56876000

0.64685900

$-0.00411700$

$-0.64161400$

$-0.47683200$

0.06612600

$-1.24202700$

$-0.12223000$

1.56544500

$-1.42492700$

0.28100000

0.35273200

$-0.07715200$

0.06693300

0.63973100

$-0.36160800$

$-0.12281500$

$-0.29268800$

0.12753300

$-0.63904800$

$-0.51514000$

0.50176000

0.99373900

0.18460900

\section{$6 \quad 2.76678100$}

0.23465600

$-0.93807900$

$6 \quad 1.69866300$

1.01146200

$-0.75679000$

$1 \quad 2.87066500$

$-1.79075000$

$-0.15820200$

$1 \quad 3.47474600$

0.28329200

$-1.76651300$

$1 \quad 1.01403000$

1.43513200

1.24416600

$1 \quad 1.35303900$

1.81906900

$-1.40324300$

$6 \quad-0.46314700$

0.24059400

0.26672000

$6 \quad-1.45581100$

1.22324700

0.32658100

$6 \quad-0.82342000$

$-1.06887900$

$-0.06203700$

$6 \quad-2.78528300$

0.90744200

0.05235300

$1-1.18292000$

2.24887300

0.59620900

$6 \quad-2.15309200$

$-1.38772300$

$-0.32954900$

$1-0.04938800$

$-1.83917500$

$-0.09262600$

$6 \quad-3.13769400$

$-0.40102900$

$-0.27627400$

$1 \quad-3.55138600$

1.68494100

0.10510800

$-2.41670500$

$-0.57856600$

$-0.65283700$

$-0.48460300$

$1-4.18023200$

$-0.60528000$

0.77259800

Pd-1-10

$6 \quad-2.06557300$

$-0.62942200$

$-2.04664700$

$1 \quad-2.20948700$

$-1.42051200$

$-2.79327200$

$1 \quad-1.76315900$

0.32073600

$-2.50421700$

$15-1.03063100$

0.77128700

0.14604900

$46-0.75104300$

$-1.41267100$

$-0.65245500$

$6 \quad-0.55093600$

$-3.95839600$

$-0.19000700$

$8 \quad-0.98224000$

$-3.45368500$

$-1.28445800$

$8 \quad-0.15323700$

$-3.18957500$

0.72446800

$6 \quad-0.55021000$

$-5.43763000$

$-0.01924700$

$1 \quad 0.33382900$

$-5.75857500$

0.54304100

$1 \quad-1.43011000$

$-5.72878200$

0.57025100

$1 \quad-0.59981100$

$-5.95346600$

$-0.98348100$

$6 \quad 4.19191900$

0.07086800

$-0.11352700$

$6 \quad 4.97984900$

$-0.63864300$

0.80153900

$6 \quad 4.82023400$

0.75844400

$-1.15636200$

$6 \quad 6.36562600$

$-0.67014700$

0.67008700

$1 \quad 4.50695400$

$-1.16777300$

1.63514700

$6 \quad 6.20752800$

0.71960200

$-1.29242500$

$1 \quad 4.21310500$

1.33209400

$-1.86015400$

$6 \quad 6.98362100$

0.00589900

$-0.38206800$

$1 \quad 6.96674200$

$-1.22618900$

1.39282200 


\begin{tabular}{|c|c|c|c|c|c|c|c|}
\hline 1 & 6.68563300 & 1.25614400 & -2.11506200 & 6 & -5.20105700 & -1.17012600 & 0.03250400 \\
\hline 1 & 8.06998400 & -0.02110700 & -0.48813500 & 1 & -4.54794000 & -1.84440800 & -1.91382200 \\
\hline 6 & 2.69090200 & 0.11851500 & 0.06426800 & 6 & -3.65853900 & 0.23121500 & 1.26827400 \\
\hline 8 & 2.03139500 & 0.68401200 & -1.07483800 & 6 & -4.88372800 & -0.42936100 & 1.17416200 \\
\hline 6 & 1.78994700 & -0.39418300 & -1.94631300 & 1 & -6.15469800 & -1.69871300 & -0.02292300 \\
\hline 6 & 1.31605500 & -1.50526600 & -1.06927400 & 1 & -3.39480000 & 0.77524000 & 2.17919100 \\
\hline 6 & 2.04005100 & -1.27311600 & 0.23690600 & 1 & -5.58951600 & -0.38225200 & 2.00587200 \\
\hline 1 & 1.10968000 & -0.09436100 & -2.75545600 & & & & \\
\hline 1 & 2.73387700 & -0.72725600 & -2.43619100 & & & & \\
\hline 1 & 1.34117100 & -2.51566700 & -1.49670100 & \multicolumn{2}{|c|}{ Pd-1-11 } & & \\
\hline 1 & 1.38425400 & -1.32184800 & 1.11912900 & 6 & -0.76778900 & 1.59782400 & -2.04545900 \\
\hline 1 & 2.44637800 & 0.77900800 & 0.91337600 & 1 & -1.39153200 & 0.86891100 & -2.58877800 \\
\hline 1 & 2.77855800 & -2.07620100 & 0.39542000 & 1 & -0.09541900 & 2.11619100 & -2.74442300 \\
\hline 6 & -1.08990900 & 2.30866700 & -0.83454900 & 15 & -1.76950000 & 0.17750200 & 0.26680700 \\
\hline 6 & -1.91116000 & 3.39499100 & -0.43766000 & 46 & 0.34014900 & 0.17480000 & -0.97559100 \\
\hline 6 & -0.33298200 & 2.39733600 & -2.01088000 & 6 & 0.53568700 & -2.34000200 & -1.40345500 \\
\hline 6 & -1.91707300 & 4.53287100 & -1.25623000 & 8 & 1.09223100 & -1.88806100 & -0.36476900 \\
\hline 6 & -0.36653900 & 3.53695500 & -2.80607000 & 8 & -0.07666700 & -1.53031700 & -2.18303400 \\
\hline 1 & 0.30367500 & 1.56557000 & -2.29918600 & 6 & 0.58123900 & -3.78421500 & -1.75662300 \\
\hline 6 & -1.16386700 & 4.61158700 & -2.42314000 & 1 & 1.38821900 & -3.95378900 & -2.48285200 \\
\hline 1 & -2.53694900 & 5.38223900 & -0.95762900 & 1 & 0.78464500 & -4.39610600 & -0.87139400 \\
\hline 1 & 0.23587600 & 3.58448400 & -3.71478100 & 1 & -0.35351900 & -4.09697000 & -2.23650100 \\
\hline 1 & -1.19783300 & 5.51769800 & -3.03143100 & 6 & 3.64644700 & -0.00116900 & -0.09097700 \\
\hline 6 & -0.28900100 & 1.15813000 & 1.75146300 & 8 & 3.10846500 & 1.32521000 & 0.21647600 \\
\hline 6 & -0.31192700 & 0.27719800 & 2.86013600 & 6 & 2.15907400 & 1.64177300 & -0.69975400 \\
\hline 6 & 0.46281400 & 2.35026300 & 1.81250300 & 6 & 2.20897700 & 0.73048500 & -1.84072100 \\
\hline 6 & 0.40580100 & 0.65797600 & 4.00382300 & 6 & 3.37789100 & -0.16626200 & -1.59045800 \\
\hline 6 & 1.16139800 & 2.69527900 & 2.96042300 & 1 & 1.04120300 & 1.51727100 & -0.12700800 \\
\hline 1 & 0.50529200 & 3.01151400 & 0.94376900 & 1 & 2.04967900 & 2.72803200 & -0.86132200 \\
\hline 6 & 1.12993200 & 1.84297000 & 4.06386600 & 1 & 1.98347300 & 1.08398000 & -2.85194000 \\
\hline 1 & 0.39258900 & -0.01005200 & 4.86909600 & 1 & 3.22375800 & -1.21708900 & -1.87117300 \\
\hline 1 & 1.73532200 & 3.62313400 & 2.98930700 & 1 & 3.04109600 & -0.73193500 & 0.47336900 \\
\hline 1 & 1.67942000 & 2.09838800 & 4.97229500 & 1 & 4.23698700 & 0.19045300 & -2.18897900 \\
\hline 6 & -1.05739900 & -1.01915700 & 2.90005900 & 6 & -1.72265200 & -0.12689600 & 2.05430600 \\
\hline 1 & -1.95075100 & -0.94271500 & 3.53918400 & 6 & -0.44573900 & -0.22736400 & 2.62998800 \\
\hline 1 & -1.38947700 & -1.38155700 & 1.92096300 & 6 & -2.88275600 & -0.25309100 & 2.85641000 \\
\hline 1 & -0.43621000 & -1.81672800 & 3.32909800 & 6 & -0.29191900 & -0.43772400 & 3.99557400 \\
\hline 6 & -2.77152800 & 3.39044500 & 0.78598900 & 1 & 0.44180300 & -0.15193100 & 1.99220100 \\
\hline 1 & -2.31233300 & 2.87447500 & 1.64030100 & 6 & -2.69394300 & -0.46477900 & 4.22882300 \\
\hline 1 & -2.99507200 & 4.41464900 & 1.10885200 & 6 & -1.42555200 & -0.55601500 & 4.79594100 \\
\hline 1 & -3.74107300 & 2.90419300 & 0.59377500 & 1 & 0.70666900 & -0.51172300 & 4.42962700 \\
\hline 6 & -3.08104500 & -0.56429300 & -0.97612600 & 1 & -3.57589900 & -0.55812100 & 4.86796100 \\
\hline 6 & -4.30487900 & -1.25281800 & -1.02836200 & 1 & -1.32424600 & -0.72113200 & 5.87062900 \\
\hline 6 & -2.76049600 & 0.17270200 & 0.20495000 & 6 & -3.08519800 & -0.78390100 & -0.53047700 \\
\hline
\end{tabular}




\begin{tabular}{|c|c|c|c|c|c|c|c|}
\hline 6 & -3.97552000 & -0.13555600 & -1.39939100 & 6 & -2.02689500 & -1.98839500 & -1.35807700 \\
\hline 6 & -3.14365000 & -2.18771500 & -0.36402100 & 6 & 0.28909700 & -1.67795500 & -2.06600300 \\
\hline 6 & -4.93774700 & -0.85692900 & -2.09877800 & 6 & -2.12654000 & -3.00437900 & -2.31839400 \\
\hline 1 & -3.92931900 & 0.95078700 & -1.52100400 & 6 & 0.16137100 & -2.69301100 & -3.00910900 \\
\hline 6 & -4.12335900 & -2.88573300 & -1.08007800 & 1 & 1.24874800 & -1.16553400 & -1.94168300 \\
\hline 6 & -5.01020800 & -2.23819200 & -1.93677800 & 6 & -1.05559100 & -3.35650500 & -3.13579600 \\
\hline 1 & -5.62779100 & -0.33918800 & -2.76748800 & 1 & -3.07851100 & -3.53350200 & -2.42065200 \\
\hline 1 & -4.18623300 & -3.97055800 & -0.95911000 & 1 & 1.01266600 & -2.96453200 & -3.63653100 \\
\hline 1 & -5.75936400 & -2.81676400 & -2.48108600 & 1 & -1.17513800 & -4.15537900 & -3.87162800 \\
\hline 6 & 5.07985800 & -0.07501200 & 0.33011000 & 6 & -1.28423200 & -0.31482500 & 1.49339500 \\
\hline 6 & 5.56422000 & -1.21711400 & 0.97339500 & 6 & -0.91500800 & -1.46858600 & 2.22385300 \\
\hline 6 & 5.95928800 & 0.97515700 & 0.04044600 & 6 & -2.23226600 & 0.57430600 & 2.01657800 \\
\hline 6 & 6.91269300 & -1.31534200 & 1.31243700 & 6 & -1.55178900 & -1.69769200 & 3.44953700 \\
\hline 1 & 4.87870400 & -2.03586400 & 1.21060600 & 6 & -2.84833700 & 0.32369000 & 3.23917400 \\
\hline 6 & 7.30268900 & 0.88189100 & 0.39131500 & 1 & -2.50333000 & 1.47174400 & 1.45272800 \\
\hline 1 & 5.58238600 & 1.87725300 & -0.44947100 & 6 & -2.51006500 & -0.82194700 & 3.95534600 \\
\hline 6 & 7.78250300 & -0.26554100 & 1.02374100 & 1 & -1.27786100 & -2.58833700 & 4.02246100 \\
\hline 1 & 7.28364800 & -2.21260700 & 1.81226600 & 1 & -3.58934900 & 1.02438200 & 3.63016800 \\
\hline 1 & 7.98086500 & 1.70894200 & 0.17096500 & 1 & -2.98566200 & -1.03154800 & 4.91643100 \\
\hline 1 & 8.83756600 & -0.33869600 & 1.29566300 & 46 & 1.68449900 & 0.61322000 & 0.17075600 \\
\hline 6 & -2.23928900 & -2.92943100 & 0.57049500 & 6 & 4.05188500 & -0.28603100 & 0.19031500 \\
\hline 1 & -1.20208300 & -2.56268400 & 0.56160500 & 8 & 3.83088100 & 0.94866900 & 0.37674200 \\
\hline 1 & -2.57666600 & -2.84393600 & 1.61652700 & 8 & 3.09099900 & -1.08910800 & -0.01263000 \\
\hline 1 & -2.21766500 & -4.00103900 & 0.33452800 & 6 & 5.45418600 & -0.80646000 & 0.23450600 \\
\hline 6 & -4.27902200 & -0.21196100 & 2.31522800 & 1 & 5.62055900 & -1.31261100 & 1.19538700 \\
\hline 1 & -4.41909000 & 0.51872600 & 1.50796500 & 1 & 5.61188500 & -1.55443000 & -0.55168800 \\
\hline 1 & -4.58050700 & -1.18501600 & 1.89433600 & 1 & 6.18414100 & 0.00438000 & 0.13981600 \\
\hline 1 & -4.99932000 & 0.02456300 & 3.10828600 & 6 & -3.21212900 & -1.71097100 & -0.48396600 \\
\hline 6 & -1.49837400 & 2.49709700 & -1.13381600 & 1 & -3.36198000 & -0.64381100 & -0.27601400 \\
\hline 6 & -1.57901600 & 3.87628100 & -1.36393800 & 1 & -4.13307600 & -2.09785400 & -0.93923400 \\
\hline 6 & -2.13524600 & 1.95089700 & 0.00508100 & 1 & -3.11135500 & -2.19541300 & 0.50102700 \\
\hline 6 & -2.30339000 & 4.69372300 & -0.49578400 & 6 & 0.10976500 & -2.43539600 & 1.71922500 \\
\hline 1 & -1.08037100 & 4.30907300 & -2.23538500 & 1 & -0.26628100 & -3.03100000 & 0.87152800 \\
\hline 6 & -2.83391600 & 2.77654300 & 0.88115900 & 1 & 1.02201200 & -1.93173500 & 1.35913000 \\
\hline 6 & -2.92562700 & 4.14871700 & 0.62416900 & 1 & 0.40730400 & -3.14288200 & 2.50310100 \\
\hline 1 & -2.36306500 & 5.76708800 & -0.68611000 & 6 & -1.20052500 & 1.58929200 & -0.73853600 \\
\hline 1 & -3.27452500 & 2.36894400 & 1.79444700 & 6 & -0.39660400 & 2.70201500 & -0.42885400 \\
\hline \multirow[t]{3}{*}{1} & -3.46459500 & 4.79431700 & 1.32006300 & 6 & -2.36877200 & 1.72111700 & -1.49197200 \\
\hline & & & & 6 & -0.81395300 & 3.96207700 & -0.87567300 \\
\hline & & & & 6 & -2.76247000 & 2.98354500 & -1.93393200 \\
\hline Pd-1-1 & & & & 1 & -2.95357400 & 0.84001000 & -1.77039900 \\
\hline 6 & 0.85665400 & 2.47776900 & 0.35695500 & 6 & -1.98619700 & 4.09946900 & -1.61776900 \\
\hline 15 & -0.45166200 & 0.06309000 & -0.08861700 & 1 & -0.20145200 & 4.83999300 & -0.65192800 \\
\hline 6 & -0.78965600 & -1.30983000 & -1.24703500 & 1 & -3.66356200 & 3.09354700 & -2.54107100 \\
\hline
\end{tabular}




\begin{tabular}{|c|c|c|c|c|c|c|c|}
\hline 1 & -2.28911800 & 5.08832300 & -1.97135100 & 1 & -2.46379100 & 6.003333300 & -0.08066900 \\
\hline 1 & 0.67980800 & 2.62059000 & 1.43940100 & 1 & -1.43944700 & 4.43305700 & -1.71143100 \\
\hline \multirow[t]{3}{*}{1} & 1.66444600 & 3.16688700 & 0.05999800 & 15 & 2.37275400 & -0.71453500 & 0.51313400 \\
\hline & & & & 6 & 2.91783800 & 0.47767800 & 1.77725100 \\
\hline & & & & 6 & 3.54639200 & 1.61044700 & 1.22397800 \\
\hline Pd-1-2 & & & & 6 & 2.59567000 & 0.44993200 & 3.15488900 \\
\hline 6 & -2.10012400 & 4.05802400 & -0.92712100 & 6 & 3.91790100 & 2.68779700 & 2.01701300 \\
\hline 6 & -2.38436100 & 2.69659700 & -0.81605600 & 1 & 3.70130500 & 1.66754900 & 0.14292800 \\
\hline 6 & -3.21668200 & 2.18158800 & 0.17435600 & 6 & 2.97894200 & 1.55966000 & 3.92351600 \\
\hline 6 & -3.77230400 & 3.08016200 & 1.08689400 & 6 & 3.63524500 & 2.65776400 & 3.37990000 \\
\hline 6 & -3.50517100 & 4.44504800 & 1.00076200 & 1 & 4.40375700 & 3.55377400 & 1.56292000 \\
\hline 6 & -2.67382900 & 4.93368300 & -0.00647400 & 1 & 2.73469300 & 1.55357300 & 4.98902600 \\
\hline 53 & -1.49422500 & 1.36069100 & -2.20810600 & 1 & 3.90822600 & 3.49951400 & 4.02045000 \\
\hline 6 & 0.03610600 & 1.18231900 & 0.98633000 & 6 & 3.83550700 & -1.25476000 & -0.43278900 \\
\hline 6 & 0.44662600 & 2.51393900 & 1.06088400 & 6 & 5.10640300 & -0.72995900 & -0.13651600 \\
\hline 6 & 0.04892500 & 3.29208700 & 2.14881500 & 6 & 3.69681000 & -2.21921800 & -1.46746900 \\
\hline 6 & -0.74594500 & 2.73969200 & 3.15373400 & 6 & 6.23108800 & -1.11453600 & -0.85771600 \\
\hline 6 & -1.15573000 & 1.41364500 & 3.05829600 & 1 & 5.22625400 & -0.01997600 & 0.68211400 \\
\hline 6 & -0.77120700 & 0.62069200 & 1.97061500 & 6 & 4.84949000 & -2.57506700 & -2.18042600 \\
\hline 46 & 0.73432000 & 0.32884800 & -0.72877800 & 6 & 6.09839000 & -2.03384500 & -1.89472600 \\
\hline 6 & -0.39717600 & -1.33309800 & -0.30786800 & 1 & 7.20680000 & -0.69541500 & -0.60384200 \\
\hline 8 & 1.67750000 & -0.08664000 & -2.71567400 & 1 & 4.75091600 & -3.30817500 & -2.98522800 \\
\hline 6 & 2.38344700 & 0.96761600 & -2.66077600 & 1 & 6.97009800 & -2.33783400 & -2.47876700 \\
\hline 8 & 2.25946300 & 1.77813500 & -1.69874900 & 6 & 1.87277900 & -0.66373100 & 3.84410400 \\
\hline 6 & 3.41621400 & 1.20727200 & -3.71588700 & 1 & 2.48789700 & -1.57144500 & 3.92734500 \\
\hline 8 & -4.58158300 & -0.62579000 & -1.09736400 & 1 & 1.59703100 & -0.36464900 & 4.86271300 \\
\hline 16 & -3.86221000 & -1.61854200 & -0.28909300 & 1 & 0.94870500 & -0.95387500 & 3.32672900 \\
\hline 8 & -3.26640000 & -1.08108700 & 0.96774000 & 6 & 2.41580700 & -2.91003500 & -1.80435000 \\
\hline 6 & -5.18109300 & -2.74655800 & 0.35708000 & 1 & 2.20983300 & -3.73587700 & -1.10482600 \\
\hline 9 & -5.83833900 & -3.33423300 & -0.64148600 & 1 & 1.55205900 & -2.23781300 & -1.78785600 \\
\hline 8 & -2.97823500 & -2.54959300 & -1.02289600 & 1 & 2.46336500 & -3.34065800 & -2.81167600 \\
\hline 9 & -4.63425300 & -3.70685900 & 1.11511700 & 6 & 1.51360100 & -2.18683700 & 1.09962300 \\
\hline 9 & -6.06510100 & -2.086666100 & 1.10727000 & 6 & 0.17973600 & -2.28260200 & 0.67687700 \\
\hline 1 & 3.60486200 & 2.27757200 & -3.85338100 & 6 & 2.10628800 & -3.19167100 & 1.87532300 \\
\hline 1 & 4.35510000 & 0.74028300 & -3.38266500 & 6 & -0.60149600 & -3.35540300 & 1.13795300 \\
\hline 1 & 3.13246400 & 0.74161000 & -4.66605200 & 6 & 1.33263500 & -4.26658200 & 2.29414800 \\
\hline 1 & 1.07662500 & 2.95208600 & 0.27825600 & 1 & 3.16080000 & -3.12174500 & 2.15882800 \\
\hline 1 & 0.36512400 & 4.33749800 & 2.20331000 & 6 & -0.02176500 & -4.33024700 & 1.94308200 \\
\hline 1 & -1.05775600 & 3.35215100 & 4.00332700 & 1 & -1.64963000 & -3.40676100 & 0.82908800 \\
\hline 1 & -1.80323200 & 0.97650000 & 3.82318300 & 1 & 1.77869200 & -5.05368900 & 2.90598800 \\
\hline 1 & -1.15539800 & -0.39889600 & 1.91341100 & 1 & -0.63217900 & -5.16633700 & 2.29247700 \\
\hline 1 & -3.43496100 & 1.11238400 & 0.24758000 & 1 & -1.39416900 & -0.98916200 & -0.01542300 \\
\hline 1 & -4.42293600 & 2.69173400 & 1.87397200 & 1 & -0.46844000 & -1.77374400 & -1.31759200 \\
\hline 1 & -3.94983800 & 5.13518700 & 1.72162400 & & & & \\
\hline
\end{tabular}


Pd-1-3

\begin{tabular}{|c|c|c|c|}
\hline 6 & 1.19572600 & 0.57451000 & 1.96535000 \\
\hline 15 & -1.11030900 & -0.30759900 & 0.25955300 \\
\hline 46 & 1.19977600 & 0.17727800 & -0.07513300 \\
\hline 6 & 1.57891500 & -2.13433800 & -1.17353900 \\
\hline 8 & 1.37939100 & -1.12950300 & -1.91981700 \\
\hline 8 & 1.62158000 & -1.98684100 & 0.09127400 \\
\hline 6 & 1.76912700 & -3.49295300 & -1.75768300 \\
\hline 1 & 1.67851300 & -3.48052400 & -2.84860800 \\
\hline 1 & 2.75308700 & -3.89129600 & -1.47586000 \\
\hline 1 & 1.02600800 & -4.18011200 & -1.33146700 \\
\hline 6 & 0.87891800 & 2.07689100 & -0.74732500 \\
\hline 6 & 0.61315600 & 2.09629400 & -2.11745200 \\
\hline 6 & 1.01556900 & 3.26946000 & -0.04075000 \\
\hline 6 & 0.44810000 & 3.32047500 & -2.77252600 \\
\hline 1 & 0.55921800 & 1.16697300 & -2.69257900 \\
\hline 6 & 0.85507600 & 4.48873500 & -0.70673000 \\
\hline 1 & 1.23779900 & 3.28874700 & 1.02943400 \\
\hline 6 & 0.56158400 & 4.51676400 & -2.06769800 \\
\hline 1 & 0.23847300 & 3.32849900 & -3.84478000 \\
\hline 1 & 0.96454400 & 5.42105200 & -0.14696800 \\
\hline 1 & 0.43319700 & 5.47142700 & -2.58154900 \\
\hline 6 & 3.67988800 & 1.19045700 & 0.44056400 \\
\hline 8 & 4.33147100 & 0.55607300 & 1.39798100 \\
\hline 6 & 4.60261200 & -0.79877300 & 0.91742800 \\
\hline 6 & 4.40401100 & -0.73366100 & -0.58670300 \\
\hline 6 & 3.53068500 & 0.48043900 & -0.72376100 \\
\hline 1 & 5.60569000 & -1.07195500 & 1.26169300 \\
\hline 1 & 3.86041300 & -1.45556500 & 1.39847400 \\
\hline 1 & 5.34901300 & -0.55623000 & -1.12891600 \\
\hline 1 & 3.98438400 & -1.66081100 & -0.99478500 \\
\hline 1 & 3.36392400 & 2.20931700 & 0.67189400 \\
\hline 1 & 3.24070500 & 0.92775000 & -1.67437900 \\
\hline 6 & -2.53117700 & 0.77282900 & -0.11474000 \\
\hline 6 & -3.53748600 & 0.30797500 & -0.98155200 \\
\hline 6 & -2.67882700 & 2.03671500 & 0.51116000 \\
\hline 6 & -4.64827900 & 1.08687200 & -1.27689300 \\
\hline 1 & -3.47275000 & -0.69148800 & -1.41015200 \\
\hline 6 & -3.79907400 & 2.80774700 & 0.17628900 \\
\hline 6 & -4.76825900 & 2.35459500 & -0.71176600 \\
\hline 1 & -5.41861800 & 0.70016600 & -1.94645800 \\
\hline 1 & -3.91232900 & 3.78872600 & 0.64491700 \\
\hline 1 & -5.62748300 & 2.98530300 & -0.94890600 \\
\hline
\end{tabular}

$6 \quad-1.41892300$

$6 \quad-1.46861100$

$6 \quad-1.53739700$

$6 \quad-1.70996400$

$1-1.31470500$

$6 \quad-1.78528100$

$6 \quad-1.88404300$

$1-1.75939800$

$1 \quad-1.89586700$

$1-2.08069300$

$6 \quad-1.41452000$

$1-1.22015700$

$1-0.58877200$

$1 \quad-2.32899500$

$6 \quad-1.75595200$

$1-2.10677600$

$1-0.73681500$

$1 \quad-1.70570300$

$6 \quad-1.08636600$

$6-2.18816500$

$6 \quad 0.09234100$

$6 \quad-2.09666100$

$1-3.10946500$

$6 \quad 0.17711300$

$6 \quad-0.90738300$

$1 \quad-2.94723400$

$1 \quad 1.09381400$

$1-0.82883500$

$1 \quad 1.16973100$

$1 \quad 2.18278400$

$-1.92653300$

$-0.51732000$

$-3.06216000$

0.31062800

$-2.06927800$

$-1.92148000$

$-4.32264300$

$-0.22245200$

$-2.96330100$

1.38634000

$-3.35320000$

$-4.46555700$

$-5.18978600$

$-3.47208900$

$-5.44954200$

$-0.94188900$

0.02951600

$-1.13259700$

$-0.83357400$

2.54558000

2.24186100

2.16462100

3.64185300

$-0.50359100$

$-0.97880900$

$-0.10808400$

$-1.10665900$

$-1.25621500$

$-0.27370600$

$-0.76535400$

$-1.48206800$

0.01176500

$-0.87619900$

1.66383100

0.20837600

Pd-1-4

$6 \quad 1.37746400$

0.42441100

1.34240900

$15 \quad-1.25416700$

$-0.00427600$

0.11768800

$46 \quad 1.23767600$

$-0.43280700$

$-0.58641000$

$6 \quad 0.77761400$

$-2.85973100$

$-1.33152000$

$8 \quad 0.89130900$

$-2.01611100$

$-2.25168000$

$8 \quad 0.90210300$

$-2.47134300$

$-0.11001200$

$6 \quad 0.46386500$

$-4.29202700$

$-1.58652200$

$1-0.58322200$

$-4.48215400$

$-1.31207800$

$1 \quad 0.60214500$

$-4.53795200$

$-2.64409600$

$1 \quad 1.07941200$

$-4.94653600$

$-0.95865100$

$6 \quad 2.99848300$

1.58995400

$-0.90201300$ 


\begin{tabular}{|c|c|c|c|c|c|c|c|}
\hline 6 & 1.95437100 & 1.44208000 & -1.85401500 & 1 & -4.48320600 & 1.25497800 & 0.84925200 \\
\hline 6 & 2.99538600 & 2.69501700 & -0.04939400 & 6 & -2.62040200 & 1.78889400 & -2.05867300 \\
\hline 6 & 0.91522700 & 2.39547300 & -1.91168000 & 1 & -1.85975300 & 1.04957500 & -2.35403600 \\
\hline 1 & 2.05192200 & 0.71117100 & -2.66449500 & 1 & -3.57769000 & 1.24277500 & -2.03963600 \\
\hline 6 & 1.96106600 & 3.62396400 & -0.12187400 & 1 & -2.69703000 & 2.53303900 & -2.86228000 \\
\hline 1 & 3.79521700 & 2.79878800 & 0.68516000 & 6 & -0.81115800 & -0.66146200 & 1.77212300 \\
\hline 6 & 0.90810600 & 3.46779500 & -1.03545900 & 6 & 0.53877400 & -0.43617800 & 2.16143400 \\
\hline 1 & 0.13009800 & 2.28634900 & -2.66297900 & 6 & -1.60235800 & -1.53218800 & 2.51377400 \\
\hline 1 & 1.96685300 & 4.48862200 & 0.54656700 & 6 & 1.04883300 & -1.10002200 & 3.28854300 \\
\hline 1 & 0.09726300 & 4.19808800 & -1.06555700 & 6 & -1.08587700 & -2.15762000 & 3.65448500 \\
\hline 6 & 4.01227700 & 0.48469000 & -0.76825300 & 1 & -2.62103800 & -1.76192500 & 2.19168100 \\
\hline 8 & 4.63577700 & 0.55448600 & 0.49405200 & 6 & 0.23551400 & -1.94206700 & 4.04119300 \\
\hline 6 & 5.02709100 & -0.76818400 & 0.83158100 & 1 & 2.09138800 & -0.93695500 & 3.57559300 \\
\hline 6 & 3.88278900 & -1.65884400 & 0.34768600 & 1 & -1.71958300 & -2.83568700 & 4.22966400 \\
\hline 6 & 3.29612700 & -0.86072700 & -0.79382700 & 1 & 0.63751300 & -2.44520800 & 4.92257200 \\
\hline 1 & 5.97541800 & -1.02664700 & 0.32524900 & 1 & 2.43429200 & 0.49022600 & 1.63503000 \\
\hline 1 & 5.20493700 & -0.80124600 & 1.91406000 & 1 & 0.96391600 & 1.41579800 & 1.09516400 \\
\hline 1 & 4.21629100 & -2.65395500 & 0.01960000 & & & & \\
\hline 1 & 3.14684100 & -1.84898400 & 1.14596400 & & & & \\
\hline 1 & 4.77430100 & 0.54241100 & -1.57727200 & Pd-1-5 & & & \\
\hline 1 & 3.25706100 & -1.35848800 & -1.77251200 & 6 & 1.17625700 & -0.53968400 & 1.08620200 \\
\hline 6 & -1.73871900 & 1.74178900 & 0.33990000 & 15 & -1.53905500 & -0.15781000 & 0.22976400 \\
\hline 6 & -2.32343900 & 2.44026000 & -0.74279000 & 46 & 0.66491000 & -0.04490700 & -0.90355200 \\
\hline 6 & -1.48951700 & 2.40665100 & 1.54967400 & 6 & 0.54571400 & 2.27399000 & -1.96386000 \\
\hline 6 & -2.66372800 & 3.78521100 & -0.54913400 & 8 & 0.16640400 & 1.31931300 & -2.68702700 \\
\hline 6 & -1.82221200 & 3.74879500 & 1.70987500 & 8 & 0.97194700 & 2.03130100 & -0.77401100 \\
\hline 1 & -1.05351700 & 1.85993800 & 2.39152100 & 6 & 0.54208900 & 3.68450200 & -2.43607500 \\
\hline 6 & -2.42048400 & 4.43847500 & 0.65699100 & 1 & 1.51828100 & 3.91470800 & -2.88533100 \\
\hline 1 & -3.13216500 & 4.33073900 & -1.37327800 & 1 & -0.22236000 & 3.82921900 & -3.20703700 \\
\hline 1 & -1.62951100 & 4.24826400 & 2.66168400 & 1 & 0.39020900 & 4.38097400 & -1.60405700 \\
\hline 1 & -2.69959700 & 5.48783900 & 0.77409000 & 6 & 4.26301600 & -0.01791900 & -0.13909300 \\
\hline 6 & -2.73718100 & -0.91177600 & -0.42205400 & 6 & 4.10526600 & 1.36227100 & -0.29207500 \\
\hline 6 & -4.01976400 & -0.73607100 & 0.15235800 & 6 & 5.00709800 & -0.50880700 & 0.94041800 \\
\hline 6 & -2.55733700 & -1.80438600 & -1.49038700 & 6 & 4.67304400 & 2.24104800 & 0.62953900 \\
\hline 6 & -5.07136800 & -1.50034200 & -0.37258700 & 1 & 3.52567300 & 1.76213100 & -1.12667000 \\
\hline 6 & -3.62156400 & -2.54668200 & -1.99178800 & 6 & 5.57055600 & 0.37215000 & 1.86083600 \\
\hline 1 & -1.57023100 & -1.89135000 & -1.95428800 & 1 & 5.13779900 & -1.58661100 & 1.05817900 \\
\hline 6 & -4.88422400 & -2.39364400 & -1.42374800 & 6 & 5.40378300 & 1.74852200 & 1.70876700 \\
\hline 1 & -6.06797100 & -1.38324400 & 0.06163800 & 1 & 4.53775700 & 3.31728200 & 0.50413000 \\
\hline 1 & -3.46677600 & -3.23377200 & -2.82612300 & 1 & 6.14860100 & -0.01942000 & 2.70068500 \\
\hline 1 & -5.73201600 & -2.96772300 & -1.80376000 & 1 & 5.84585300 & 2.43772400 & 2.43118400 \\
\hline 6 & -4.31559200 & 0.24118700 & 1.24791400 & 6 & 3.67067900 & -0.98447400 & -1.12346800 \\
\hline 1 & -5.22834100 & -0.03964100 & 1.78862500 & 8 & 3.29307000 & -2.19876500 & -0.47540800 \\
\hline 1 & -3.50568200 & 0.33366200 & 1.98322700 & 6 & 2.50486000 & -2.90813200 & -1.39406000 \\
\hline
\end{tabular}




\begin{tabular}{|c|c|c|c|c|c|c|c|}
\hline 6 & 1.65695800 & -1.83808500 & -2.07796700 & 1 & 1.97510500 & -2.90569100 & 2.16884300 \\
\hline 6 & 2.44554400 & -0.59903600 & -1.91754400 & 1 & 0.49505500 & -4.80961600 & 2.82009900 \\
\hline 1 & 3.12550400 & -3.40670100 & -2.16517100 & 1 & 2.25715200 & -0.70524000 & 1.13968800 \\
\hline 1 & 1.93815700 & -3.68050400 & -0.85877600 & 1 & 0.89345400 & 0.43565800 & 1.51389100 \\
\hline 1 & 1.28027100 & -2.04757800 & -3.08982200 & & & & \\
\hline 1 & 0.63685100 & -1.79489200 & -1.48495700 & & & & \\
\hline 1 & 4.44947300 & -1.22710400 & -1.88973300 & Pd-1-6 & & & \\
\hline 1 & 2.54166100 & 0.10463600 & -2.75104300 & 6 & 1.33645400 & -1.24503700 & -0.35721600 \\
\hline 6 & -1.86328200 & 1.21304100 & 1.37471200 & 15 & -1.40261900 & -0.46329200 & 0.00651100 \\
\hline 6 & -1.59427400 & 1.06896100 & 2.74345200 & 46 & 0.45964800 & 0.56815400 & -0.89551500 \\
\hline 6 & -2.32634500 & 2.44634600 & 0.86152500 & 6 & 0.07897200 & 2.94922500 & 0.06248300 \\
\hline 6 & -1.79561100 & 2.13001900 & 3.62015200 & 8 & -0.33700700 & 2.65325000 & -1.10192300 \\
\hline 1 & -1.24252300 & 0.10829100 & 3.13246600 & 8 & 0.66062200 & 2.06550900 & 0.76234700 \\
\hline 6 & -2.52018900 & 3.49582900 & 1.76709800 & 6 & -0.08036100 & 4.33590100 & 0.58794000 \\
\hline 6 & -2.26307400 & 3.34679300 & 3.12767800 & 1 & -0.13125100 & 4.33778500 & 1.68266500 \\
\hline 1 & -1.58958800 & 2.00512200 & 4.68485800 & 1 & 0.79825500 & 4.93088500 & 0.30068200 \\
\hline 1 & -2.88212400 & 4.45534900 & 1.38802600 & 1 & -0.96005200 & 4.82540700 & 0.15587100 \\
\hline 1 & -2.42453500 & 4.18697600 & 3.80612800 & 6 & 4.11936300 & 0.25058300 & 0.07093000 \\
\hline 6 & -3.05523400 & -0.56642800 & -0.68044900 & 6 & 3.62676700 & 0.86598300 & 1.22546600 \\
\hline 6 & -4.33302600 & -0.62434700 & -0.07187000 & 6 & 4.81421000 & -0.95878900 & 0.18161900 \\
\hline 6 & -2.91218700 & -0.80369200 & -2.05695700 & 6 & 3.80704000 & 0.26738500 & 2.47326500 \\
\hline 6 & -5.42275900 & -0.94087300 & -0.89382100 & 1 & 3.07203900 & 1.80478700 & 1.16383100 \\
\hline 6 & -4.01396100 & -1.11623300 & -2.84598900 & 6 & 4.99211900 & -1.55404400 & 1.42852200 \\
\hline 1 & -1.92306100 & -0.71511100 & -2.51902000 & 1 & 5.19961100 & -1.44078000 & -0.71950500 \\
\hline 6 & -5.27435500 & -1.18449700 & -2.25647200 & 6 & 4.48431400 & -0.94585900 & 2.57751100 \\
\hline 1 & -6.41739700 & -0.99553700 & -0.44331600 & 1 & 3.41027100 & 0.75566200 & 3.36645700 \\
\hline 1 & -3.88938800 & -1.29590700 & -3.91530600 & 1 & 5.53459100 & -2.49924400 & 1.50392800 \\
\hline 1 & -6.15065400 & -1.42612600 & -2.86156400 & 1 & 4.62468100 & -1.41484100 & 3.55389400 \\
\hline 6 & -2.65387100 & 2.64171100 & -0.58610800 & 6 & 3.89604900 & 0.85310700 & -1.29329900 \\
\hline 1 & -1.97633600 & 2.09900000 & -1.26288600 & 8 & 3.78180900 & -0.17566600 & -2.27622500 \\
\hline 1 & -3.66809300 & 2.28040000 & -0.82349600 & 6 & 2.88009700 & 0.22497800 & -3.28529600 \\
\hline 1 & -2.62568100 & 3.70393900 & -0.86113100 & 6 & 2.07341900 & 1.31960700 & -2.66695100 \\
\hline 6 & -4.57642000 & -0.33220600 & 1.37662100 & 6 & 2.66820000 & 1.68828400 & -1.50269600 \\
\hline 1 & -5.53500100 & -0.75260900 & 1.70533100 & 1 & 3.40672300 & 0.62167800 & -4.17823000 \\
\hline 1 & -3.79466200 & -0.72482400 & 2.04072500 & 1 & 2.30094900 & -0.64875900 & -3.62487400 \\
\hline 1 & -4.62052900 & 0.75178300 & 1.56914600 & 1 & 1.28206100 & 1.87190400 & -3.17849000 \\
\hline 6 & -1.05318800 & -1.61684200 & 1.22510300 & 1 & 0.11434900 & -0.29761200 & -2.12237300 \\
\hline 6 & -1.86805800 & -2.69160900 & 1.56185300 & 1 & 4.76713200 & 1.50485500 & -1.54291200 \\
\hline 6 & 0.34496000 & -1.68198900 & 1.46293200 & 1 & 2.44550700 & 2.58416700 & -0.92386800 \\
\hline 6 & -1.30843500 & -3.83323900 & 2.15144900 & 6 & -1.44111900 & -0.06458400 & 1.76623200 \\
\hline 1 & -2.93640900 & -2.67248400 & 1.33101200 & 6 & -0.75638800 & -0.93606000 & 2.63138000 \\
\hline 6 & 0.89380600 & -2.84653500 & 2.01907600 & 6 & -2.02314500 & 1.13027300 & 2.25861300 \\
\hline 6 & 0.06427200 & -3.90923100 & 2.37753600 & 6 & -0.66305700 & -0.65820800 & 3.98894300 \\
\hline 1 & -1.95169000 & -4.67711100 & 2.40856400 & 1 & -0.30023400 & -1.85010300 & 2.24096600 \\
\hline
\end{tabular}




\begin{tabular}{|c|c|c|c|c|c|c|c|}
\hline 6 & -1.91556000 & 1.37419300 & 3.63253600 & 6 & 0.79414700 & 2.56382000 & 1.27381100 \\
\hline 6 & -1.24924700 & 0.50227600 & 4.48958700 & 6 & 0.35076600 & 4.00184700 & -1.04743600 \\
\hline 1 & -0.13468200 & -1.34607800 & 4.65126200 & 6 & 0.43471000 & 3.90022800 & 1.35796900 \\
\hline 1 & -2.36327500 & 2.28607900 & 4.03642000 & 1 & 0.93475600 & 1.99170000 & 2.19360700 \\
\hline 1 & -1.18373900 & 0.73495900 & 5.55446700 & 6 & 0.21605400 & 4.62276400 & 0.18854100 \\
\hline 6 & -2.96672100 & -0.10400700 & -0.82234300 & 1 & 0.14636400 & 4.56714900 & -1.96037100 \\
\hline 6 & -4.20859700 & -0.48627000 & -0.25624200 & 1 & 0.29923000 & 4.36614300 & 2.33525000 \\
\hline 6 & -2.91385200 & 0.54471700 & -2.06636300 & 1 & -0.08450900 & 5.67155000 & 0.23777800 \\
\hline 6 & -5.36054600 & -0.20487100 & -1.00251700 & 6 & 1.93199500 & -0.24372000 & 1.73155100 \\
\hline 6 & -4.07843800 & 0.81511400 & -2.77433700 & 6 & 1.07942600 & -1.01428900 & 2.53729900 \\
\hline 1 & -1.94879500 & 0.86147600 & -2.47094400 & 6 & 3.17255900 & 0.21031300 & 2.24248900 \\
\hline 6 & -5.30587100 & 0.43361700 & -2.23808600 & 6 & 1.44871500 & -1.36412200 & 3.83371300 \\
\hline 1 & -6.32998100 & -0.49930000 & -0.59188600 & 1 & 0.10980900 & -1.34626900 & 2.16148100 \\
\hline 1 & -4.02555700 & 1.32426600 & -3.73805200 & 6 & 3.51466900 & -0.16145300 & 3.54757000 \\
\hline 1 & -6.22991800 & 0.63681800 & -2.78325300 & 6 & 2.67427300 & -0.94239600 & 4.33690900 \\
\hline 6 & -4.36664100 & -1.11914800 & 1.09369400 & 1 & 0.76867400 & -1.96245600 & 4.44262900 \\
\hline 1 & -5.28059300 & -1.72504200 & 1.13428100 & 1 & 4.46957200 & 0.18450700 & 3.95298100 \\
\hline 1 & -3.53007400 & -1.76177000 & 1.39450800 & 1 & 2.97690300 & -1.21002100 & 5.35205100 \\
\hline 1 & -4.46221000 & -0.35797800 & 1.88532300 & 46 & -0.41437200 & -1.21518900 & -0.44800500 \\
\hline 6 & -2.75804400 & 2.11481900 & 1.40315100 & 6 & -1.89588300 & -3.18342900 & 0.22723800 \\
\hline 1 & -2.30575900 & 2.27147400 & 0.41490900 & 8 & -1.98382800 & -2.62997000 & -0.91508900 \\
\hline 1 & -3.79574900 & 1.79802300 & 1.21208500 & 8 & -0.95166800 & -2.87693100 & 1.00601400 \\
\hline 1 & -2.81860900 & 3.09082400 & 1.90103900 & 6 & -2.95259600 & -4.15476000 & 0.63747600 \\
\hline 6 & -0.96091800 & -2.20946300 & -0.21362800 & 1 & -2.62921900 & -4.76111100 & 1.48979800 \\
\hline 6 & 0.41678200 & -2.40973000 & -0.40053000 & 1 & -3.84487900 & -3.58454900 & 0.93136100 \\
\hline 6 & -1.86016400 & -3.27685900 & -0.25668000 & 1 & -3.24331400 & -4.79456900 & -0.20341000 \\
\hline 6 & 0.88436500 & -3.71183200 & -0.60408700 & 16 & -2.45006000 & 1.22761400 & -0.01858500 \\
\hline 6 & -1.37611800 & -4.56937500 & -0.45824200 & 8 & -2.47505100 & 2.43136300 & 0.80262800 \\
\hline 1 & -2.93636500 & -3.10807700 & -0.17925400 & 8 & -1.81152900 & 0.03492800 & 0.68452800 \\
\hline 6 & -0.00841100 & -4.78328900 & -0.62272200 & 8 & -2.03329800 & 1.34219800 & -1.42520800 \\
\hline 1 & 1.95308100 & -3.88215900 & -0.75718500 & 6 & -4.21715500 & 0.67083200 & -0.09292100 \\
\hline 1 & -2.07397200 & -5.40675800 & -0.51114600 & 9 & -4.33553600 & -0.43792900 & -0.81819000 \\
\hline 1 & 0.36669800 & -5.79457800 & -0.79295300 & 9 & -4.67324100 & 0.42257800 & 1.13229700 \\
\hline 1 & 2.22943400 & -1.36651600 & -0.98530100 & 9 & -4.96972700 & 1.62027400 & -0.64369000 \\
\hline \multirow[t]{3}{*}{1} & 1.64782000 & -0.96776300 & 0.66628200 & 1 & -0.38681700 & -0.27060100 & -1.64479900 \\
\hline & & & & 6 & 4.11858900 & 1.06565000 & 1.46486100 \\
\hline & & & & 1 & 3.60185900 & 1.86783500 & 0.91728600 \\
\hline Pd-1-7 & & & & 1 & 4.85180500 & 1.54237100 & 2.12719600 \\
\hline 6 & 1.01534000 & -2.34275600 & -1.38055300 & 1 & 4.68584400 & 0.47812600 & 0.72660700 \\
\hline 1 & 0.51141800 & -2.86461700 & -2.20669700 & 6 & 0.81782600 & 2.07029900 & -2.54139800 \\
\hline 1 & 1.25928200 & -3.08296300 & -0.59889300 & 1 & 1.83892700 & 2.15224600 & -2.94724500 \\
\hline 15 & 1.32211200 & 0.16462200 & 0.05706800 & 1 & 0.55049400 & 1.00589200 & -2.58563700 \\
\hline 6 & 0.95899900 & 1.93602800 & 0.02568100 & 1 & 0.14378400 & 2.59352900 & -3.23042500 \\
\hline 6 & 0.71316200 & 2.65488700 & -1.17010300 & 6 & 2.21119000 & -1.56321200 & -1.82403700 \\
\hline
\end{tabular}




\begin{tabular}{|c|c|c|c|c|c|c|c|}
\hline 6 & 3.04813300 & -2.02510400 & -2.84835500 & 6 & -3.02227100 & -0.74673400 & 2.73320700 \\
\hline 6 & 2.51674700 & -0.32704200 & -1.22337600 & 6 & -0.63212500 & -1.18392600 & 2.50421700 \\
\hline 6 & 4.14406400 & -1.27375000 & -3.26703700 & 6 & -2.95409400 & -1.37416700 & 3.98540000 \\
\hline 1 & 2.82296600 & -2.97928100 & -3.33221800 & 6 & -0.60000000 & -1.80441000 & 3.74558100 \\
\hline 6 & 3.60067900 & 0.43852700 & -1.66180100 & 1 & 0.28085500 & -1.15752400 & 1.90634100 \\
\hline 6 & 4.41736100 & -0.03627400 & -2.68405000 & 6 & -1.76893000 & -1.88798400 & 4.49721900 \\
\hline 1 & 4.77761200 & -1.64725600 & -4.07494400 & 1 & -3.87510400 & -1.46349800 & 4.56773400 \\
\hline 1 & 3.78171000 & 1.42813400 & -1.23614700 & 1 & 0.33378200 & -2.22941700 & 4.11719700 \\
\hline \multirow[t]{3}{*}{1} & 5.25504300 & 0.56774000 & -3.03864900 & 1 & -1.76314800 & -2.37036100 & 5.47676400 \\
\hline & & & & 6 & -2.88197100 & -0.67190300 & -0.74931700 \\
\hline & & & & 6 & -3.28512000 & -0.12609000 & -1.99322900 \\
\hline Pd-1-8 & & & & 6 & -3.26710200 & -1.97628500 & -0.38558200 \\
\hline 15 & -1.73650600 & 0.17901100 & 0.35809000 & 6 & -4.13083800 & -0.90359800 & -2.79333500 \\
\hline 46 & 0.40323700 & 0.07994100 & -0.48604100 & 6 & -4.09933800 & -2.72404700 & -1.20748600 \\
\hline 6 & -0.17344400 & -2.00207600 & -1.91735500 & 1 & -2.91299500 & -2.40961500 & 0.55305800 \\
\hline 8 & -0.23806000 & -0.83673400 & -2.41763200 & 6 & -4.54274500 & -2.17743700 & -2.41095100 \\
\hline 8 & 0.19582100 & -2.14228200 & -0.70877200 & 1 & -4.46134700 & -0.49520800 & -3.75159800 \\
\hline 6 & -0.50678600 & -3.19302500 & -2.74880500 & 1 & -4.39829200 & -3.73064200 & -0.90942800 \\
\hline 1 & 0.37448700 & -3.47925000 & -3.33938600 & 1 & -5.20141100 & -2.75248400 & -3.06529700 \\
\hline 1 & -0.78545200 & -4.04784700 & -2.12399100 & 6 & -2.82927900 & 1.20985300 & -2.48089200 \\
\hline 1 & -1.30811900 & -2.95518700 & -3.45745200 & 1 & -3.31654700 & 2.04184100 & -1.95005700 \\
\hline 6 & 5.04332500 & 0.02710900 & 0.48638700 & 1 & -1.74343500 & 1.33137000 & -2.35677900 \\
\hline 6 & 5.27361900 & -1.18469800 & 1.14910300 & 1 & -3.04774000 & 1.33129700 & -3.54826200 \\
\hline 6 & 6.12586800 & 0.74115200 & -0.03256900 & 6 & -4.36871500 & -0.27243700 & 2.28021400 \\
\hline 6 & 6.56785000 & -1.67902000 & 1.28437500 & 1 & -4.41762300 & -0.00300600 & 1.21967300 \\
\hline 1 & 4.43491000 & -1.74588400 & 1.57382500 & 1 & -5.12329000 & -1.05519400 & 2.43955300 \\
\hline 6 & 7.42111900 & 0.24297000 & 0.10331200 & 1 & -4.70262900 & 0.59542500 & 2.86893800 \\
\hline 1 & 5.94942200 & 1.69995700 & -0.52408300 & 6 & -0.88685700 & 2.75055600 & 0.02060200 \\
\hline 6 & 7.64524500 & -0.96689000 & 0.75683700 & 6 & -0.96456300 & 4.14551900 & 0.13031800 \\
\hline 1 & 6.73706200 & -2.62386400 & 1.80528900 & 6 & -1.97829200 & 1.97880400 & 0.46011500 \\
\hline 1 & 8.26253500 & 0.81008100 & -0.30076200 & 6 & -2.10951800 & 4.75707900 & 0.63033400 \\
\hline 1 & 8.66084000 & -1.35411300 & 0.86127600 & 1 & -0.11672900 & 4.75479800 & -0.19260100 \\
\hline 6 & 3.62541700 & 0.54810900 & 0.34366300 & 6 & -3.13419900 & 2.59852800 & 0.95409500 \\
\hline 8 & 3.53604800 & 1.75729000 & -0.39885400 & 6 & -3.19968400 & 3.98527500 & 1.03286400 \\
\hline 6 & 3.23319600 & 1.45353700 & -1.74559500 & 1 & -2.15210000 & 5.84544000 & 0.70588800 \\
\hline 6 & 2.58593300 & 0.11062200 & -1.69886100 & 1 & -3.98740300 & 2.00646800 & 1.28183000 \\
\hline 6 & 2.80672400 & -0.42554700 & -0.46738900 & 1 & -4.09973900 & 4.46350300 & 1.42339700 \\
\hline 1 & 2.61652500 & 2.26176700 & -2.16956800 & 6 & 0.30401600 & 2.13408500 & -0.62997800 \\
\hline 1 & 4.14464900 & 1.39146700 & -2.37691500 & 1 & 1.25652800 & 2.56657700 & -0.28945100 \\
\hline 1 & 2.19625400 & -0.41287100 & -2.57370300 & 1 & 0.25374200 & 2.20342800 & -1.73219000 \\
\hline 1 & 0.76841700 & 0.59359700 & 0.91713900 & & & & \\
\hline 1 & 3.20010100 & 0.74409700 & 1.34467100 & & & & \\
\hline 1 & 2.62923900 & -1.46554100 & -0.18286800 & Pd-1-9 & & & \\
\hline 6 & -1.81944800 & -0.62930000 & 1.99189800 & 15 & 1.66449700 & 0.43654600 & 0.06799700 \\
\hline
\end{tabular}




\begin{tabular}{|c|c|c|c|c|c|c|c|}
\hline 46 & -0.43104200 & -0.74231200 & 0.01143000 & 6 & 4.53012400 & -2.01607400 & -1.40301600 \\
\hline 6 & 0.65890400 & -2.86011600 & -0.93988800 & 1 & 3.06480500 & -0.61779600 & -2.12307500 \\
\hline 8 & 0.44577100 & -2.66825100 & 0.31247100 & 6 & 5.10719200 & -2.60292100 & -0.27896300 \\
\hline 8 & 0.26474300 & -1.99767200 & -1.76764500 & 1 & 5.09882100 & -2.73692500 & 1.86953100 \\
\hline 6 & 1.36555900 & -4.10208000 & -1.35348400 & 1 & 4.86699500 & -2.28379700 & -2.40656900 \\
\hline 1 & 0.75240000 & -4.97859800 & -1.10683200 & 1 & 5.91023700 & -3.33456800 & -0.39035400 \\
\hline 1 & 1.57247900 & -4.09533100 & -2.42818100 & 6 & 3.15967100 & -1.03002500 & 2.57721100 \\
\hline 1 & 2.30221000 & -4.20142200 & -0.79019800 & 1 & 3.40472300 & -0.00444900 & 2.89173500 \\
\hline 6 & -5.06794100 & 0.35880800 & -0.05319000 & 1 & 2.07002600 & -1.14085300 & 2.67347200 \\
\hline 6 & -5.34521500 & 1.18709900 & -1.14831900 & 1 & 3.61829600 & -1.71082100 & 3.30380200 \\
\hline 6 & -6.10366300 & -0.38578100 & 0.51882100 & 6 & 4.40913000 & 2.02681300 & -0.79610600 \\
\hline 6 & -6.63331900 & 1.25860700 & -1.67137600 & 1 & 4.26318900 & 1.62535400 & 0.21334500 \\
\hline 1 & -4.55136900 & 1.79729400 & -1.59163700 & 1 & 5.06064300 & 1.30460800 & -1.31368800 \\
\hline 6 & -7.39231700 & -0.31441200 & -0.00795200 & 1 & 4.98345100 & 2.95894800 & -0.70942700 \\
\hline 1 & -5.89623200 & -1.00611600 & 1.39308700 & 6 & 0.29399600 & 1.10590100 & 2.31038200 \\
\hline 6 & -7.65969200 & 0.50313200 & -1.10414100 & 6 & -0.08809300 & 1.91937700 & 3.38682600 \\
\hline 1 & -6.83869800 & 1.91065000 & -2.52281500 & 6 & 1.45115900 & 1.44313800 & 1.57637500 \\
\hline 1 & -8.19504100 & -0.89795400 & 0.44790900 & 6 & 0.68891100 & 3.01614200 & 3.75347100 \\
\hline 1 & -8.67033200 & 0.55861600 & -1.51360800 & 1 & -0.99370700 & 1.67722300 & 3.94894300 \\
\hline 6 & -3.67123200 & 0.30188000 & 0.52419200 & 6 & 2.21082500 & 2.55888600 & 1.93389600 \\
\hline 8 & -3.51996800 & -0.69017100 & 1.52728300 & 6 & 1.83710900 & 3.33582700 & 3.03059000 \\
\hline 6 & -3.16745100 & -1.90989100 & 0.90397500 & 1 & 0.38420600 & 3.63690000 & 4.59847100 \\
\hline 6 & -2.39903700 & -1.52302000 & -0.31509600 & 1 & 3.07905200 & 2.85568400 & 1.34304700 \\
\hline 6 & -2.64347000 & -0.10132000 & -0.55442300 & 1 & 2.42887400 & 4.21277200 & 3.29948200 \\
\hline 1 & -2.61574400 & -2.53614600 & 1.62310300 & 6 & -0.47285300 & -0.12235100 & 2.00454500 \\
\hline 1 & -4.06630300 & -2.48954600 & 0.60085000 & 1 & -1.52980600 & -0.07942800 & 2.30296200 \\
\hline 1 & -2.26941500 & -2.22773700 & -1.14184500 & 1 & -0.01415600 & -1.04538300 & 2.39776700 \\
\hline 1 & -1.66188500 & 0.55531500 & -0.36753100 & & & & \\
\hline 1 & -3.41573900 & 1.26600400 & 0.99753800 & & & & \\
\hline 1 & -2.86033200 & 0.18469500 & -1.59493400 & \multicolumn{2}{|c|}{ Pd-1-TS1 } & & \\
\hline 6 & 1.91815500 & 1.58299900 & -1.32586800 & 6 & 3.07561900 & 3.33013000 & -0.60216200 \\
\hline 6 & 3.14463600 & 2.24950500 & -1.56891200 & 6 & 3.34969800 & 2.11955400 & 0.03732500 \\
\hline 6 & 0.81709200 & 1.81544000 & -2.16630100 & 6 & 4.45850500 & 1.34067900 & -0.28893500 \\
\hline 6 & 3.18645000 & 3.15089700 & -2.64216700 & 6 & 5.30802700 & 1.79676000 & -1.29745500 \\
\hline 6 & 0.89094300 & 2.71154100 & -3.22566200 & 6 & 5.04454100 & 2.99281500 & -1.96257000 \\
\hline 1 & -0.11317900 & 1.26570300 & -1.99487000 & 6 & 3.93139300 & 3.75956300 & -1.61393100 \\
\hline 6 & 2.08538700 & 3.38800200 & -3.45808400 & 53 & 1.97582200 & 1.42652800 & 1.49482000 \\
\hline 1 & 4.12273800 & 3.68025700 & -2.83853500 & 6 & 0.19975500 & 1.53407000 & -0.28506100 \\
\hline 1 & 0.02412500 & 2.87475100 & -3.86829700 & 6 & -0.42604000 & 2.77988300 & -0.31824000 \\
\hline 1 & 2.16465100 & 4.09868100 & -4.28318300 & 6 & -0.59789200 & 3.38884400 & -1.56381400 \\
\hline 6 & 3.07264900 & -0.71271300 & 0.04396700 & 6 & -0.10531100 & 2.78978200 & -2.72208000 \\
\hline 6 & 3.62488600 & -1.33038100 & 1.18880500 & 6 & 0.54330800 & 1.55710200 & -2.64436400 \\
\hline 6 & 3.51620300 & -1.07853400 & -1.23935000 & 6 & 0.71846300 & 0.91083800 & -1.41827000 \\
\hline 6 & 4.65132100 & -2.26265300 & 0.99223300 & 46 & -1.11760400 & 0.19989000 & 1.16739000 \\
\hline
\end{tabular}




\begin{tabular}{|c|c|c|c|c|c|c|c|}
\hline 6 & -0.11439700 & -1.50907300 & 0.65002300 & 1 & -7.59153800 & -0.79025900 & -0.45972500 \\
\hline 8 & -0.25851700 & 0.78898400 & 3.18281800 & 1 & -5.70371100 & -2.71357100 & 2.89798400 \\
\hline 6 & -1.13255600 & 1.70954200 & 3.29991700 & 1 & -7.76104700 & -2.09727100 & 1.66509100 \\
\hline 8 & -1.96685500 & 1.92288700 & 2.37694400 & 6 & -1.99562100 & -0.37791700 & -3.68654800 \\
\hline 6 & -1.13736300 & 2.53901300 & 4.54426200 & 1 & -2.63997000 & -1.24476700 & -3.89541400 \\
\hline 8 & 4.21260900 & -1.26662400 & 1.47179600 & 1 & -1.62547100 & -0.01727700 & -4.65516700 \\
\hline 16 & 3.47736100 & -2.05659300 & 0.46603900 & 1 & -1.13339900 & -0.75525300 & -3.12131900 \\
\hline 8 & 2.82958000 & -1.24028500 & -0.59738200 & 6 & -3.14950500 & -2.18847500 & 2.29331800 \\
\hline 6 & 4.82401800 & -2.89600600 & -0.48802000 & 1 & -2.44975000 & -2.77280000 & 1.67639900 \\
\hline 9 & 5.60012600 & -3.62583700 & 0.30873800 & 1 & -2.58095000 & -1.32578700 & 2.68431400 \\
\hline 8 & 2.65789200 & -3.16283400 & 0.98541300 & 1 & -3.42479900 & -2.80935800 & 3.15456000 \\
\hline 9 & 4.31256900 & -3.69865400 & -1.42571400 & 6 & -1.91788200 & -2.09257500 & -0.98592900 \\
\hline 9 & 5.59502400 & -1.98644500 & -1.09921100 & 6 & -0.64278200 & -2.34770900 & -0.46142300 \\
\hline 1 & -1.97771100 & 3.24014400 & 4.56097500 & 6 & -2.52984800 & -2.97540000 & -1.88563500 \\
\hline 1 & -1.17614900 & 1.88919000 & 5.42754000 & 6 & 0.08080300 & -3.44830300 & -0.95154300 \\
\hline 1 & -0.19516200 & 3.09988800 & 4.61367500 & 6 & -1.81828300 & -4.08064200 & -2.33401400 \\
\hline 1 & -0.79730900 & 3.25521500 & 0.59207500 & 1 & -3.54632900 & -2.78304600 & -2.24312100 \\
\hline 1 & -1.11132700 & 4.35290600 & -1.61147100 & 6 & -0.50847100 & -4.29419600 & -1.88537400 \\
\hline 1 & -0.22207300 & 3.28885700 & -3.68693100 & 1 & 1.09099200 & -3.62565800 & -0.57062100 \\
\hline 1 & 0.94255200 & 1.08171400 & -3.54456300 & 1 & -2.27520300 & -4.77441700 & -3.04329600 \\
\hline 1 & 1.28755500 & -0.02317000 & -1.35179700 & 1 & 0.05637400 & -5.15144700 & -2.25985100 \\
\hline 1 & 4.64847700 & 0.39834100 & 0.22924200 & 1 & 0.92641500 & -1.20705900 & 0.47326600 \\
\hline 1 & 6.17571200 & 1.19040300 & -1.56822400 & 1 & -0.14582400 & -2.05293500 & 1.61216100 \\
\hline 1 & 5.71130300 & 3.33340500 & -2.75832700 & & & & \\
\hline 1 & 3.72392300 & 4.69964500 & -2.13078500 & & & & \\
\hline 1 & 2.19922800 & 3.92432300 & -0.33152700 & \multicolumn{2}{|c|}{ Pd-1-TS2 } & & \\
\hline 15 & -2.62767900 & -0.55827200 & -0.35052500 & 6 & 1.26786500 & -0.44374000 & 1.74862800 \\
\hline 6 & -3.00061900 & 0.72969200 & -1.58780700 & 15 & -1.14787900 & 0.02020900 & 0.24397600 \\
\hline 6 & -3.62093700 & 1.85311300 & -1.00669400 & 46 & 1.20709200 & -0.70320300 & -0.34193000 \\
\hline 6 & -2.72811700 & 0.71596900 & -2.97313000 & 6 & 0.45827400 & -2.72392500 & -1.77014400 \\
\hline 6 & -4.03445900 & 2.93094400 & -1.77788200 & 8 & 0.81075900 & -1.66773000 & -2.37405700 \\
\hline 1 & -3.78879300 & 1.87490100 & 0.07548300 & 8 & 0.48864400 & -2.75617900 & -0.49647800 \\
\hline 6 & -3.16363700 & 1.81863200 & -3.72627100 & 6 & -0.03205100 & -3.91272400 & -2.52139000 \\
\hline 6 & -3.81692800 & 2.90363500 & -3.15417500 & 1 & 0.30442000 & -4.84234600 & -2.04879400 \\
\hline 1 & -4.52061000 & 3.78602700 & -1.30349900 & 1 & -1.13093400 & -3.91945400 & -2.49122500 \\
\hline 1 & -2.96507900 & 1.81760300 & -4.80193700 & 1 & 0.28371000 & -3.87816300 & -3.56906900 \\
\hline 1 & -4.13931600 & 3.73784000 & -3.78195800 & 6 & 2.10432800 & 1.20847200 & -0.71775200 \\
\hline 6 & -4.27134600 & -1.00851900 & 0.32508100 & 6 & 1.63028100 & 1.66984500 & -1.96337600 \\
\hline 6 & -5.44300000 & -0.66793000 & -0.36905600 & 6 & 2.38572900 & 2.14394800 & 0.29460700 \\
\hline 6 & -4.35651700 & -1.76449700 & 1.52042300 & 6 & 1.43547600 & 3.02773500 & -2.18100000 \\
\hline 6 & -6.69341000 & -1.05884000 & 0.10041200 & 1 & 1.42455100 & 0.95050200 & -2.76438300 \\
\hline 1 & -5.38059900 & -0.09366000 & -1.29605500 & 6 & 2.17984500 & 3.50077500 & 0.07694800 \\
\hline 6 & -5.62832800 & -2.13346800 & 1.97431900 & 1 & 2.81072900 & 1.81778000 & 1.24720700 \\
\hline 6 & -6.78570300 & -1.78911200 & 1.28158100 & 6 & 1.69991700 & 3.94308300 & -1.15773600 \\
\hline
\end{tabular}




\begin{tabular}{|c|c|c|c|c|c|c|c|}
\hline 1 & 1.07460600 & 3.37601700 & -3.15145700 & 6 & -2.19460600 & -1.85305600 & 2.14215300 \\
\hline 1 & 2.40313600 & 4.21884700 & 0.86877100 & 6 & 0.35444900 & -2.27194100 & 3.21151900 \\
\hline 1 & 1.54563000 & 5.01113500 & -1.32875800 & 6 & -1.99333900 & -2.82875000 & 3.12476100 \\
\hline 6 & 3.68289800 & 0.01252300 & -0.93968000 & 1 & -3.18181700 & -1.74350700 & 1.68633200 \\
\hline 8 & 4.61027600 & 0.37799000 & -0.05048800 & 6 & -0.72355000 & -3.03620400 & 3.65673400 \\
\hline 6 & 4.67395500 & -0.58744500 & 1.02304000 & 1 & 1.35545100 & -2.44737500 & 3.61501600 \\
\hline 6 & 3.99954600 & -1.84109200 & 0.48301700 & 1 & -2.83184700 & -3.44642800 & 3.45200900 \\
\hline 6 & 3.19231200 & -1.32508300 & -0.67978500 & 1 & -0.56602600 & -3.81197900 & 4.40847100 \\
\hline 1 & 5.73364400 & -0.70952900 & 1.27734700 & 1 & 2.25120900 & -0.74472200 & 2.12922900 \\
\hline 1 & 4.17254900 & -0.15596600 & 1.90404600 & 1 & 1.11780000 & 0.63535400 & 1.88581400 \\
\hline 1 & 4.74318000 & -2.56174300 & 0.10488900 & & & & \\
\hline 1 & 3.41078400 & -2.38595100 & 1.23543900 & & & & \\
\hline 1 & 3.87871600 & 0.38458600 & -1.94755700 & \multicolumn{2}{|c|}{ Pd-1-TS3 } & & \\
\hline 1 & 3.02679700 & -1.97450800 & -1.54427500 & 15 & 1.44697300 & -0.17106800 & -0.34046300 \\
\hline 6 & -1.24638400 & 1.75713000 & 0.77975800 & 46 & -0.66649800 & -0.06715100 & 0.77360500 \\
\hline 6 & -1.46467600 & 2.77043000 & -0.18291600 & 6 & -0.54967900 & 2.30221800 & 1.80065000 \\
\hline 6 & -1.01688700 & 2.09918300 & 2.12176000 & 8 & -0.11059500 & 1.32547900 & 2.47537400 \\
\hline 6 & -1.44192000 & 4.10095300 & 0.25282200 & 8 & -1.07262900 & 2.08970800 & 0.65782200 \\
\hline 6 & -1.00014000 & 3.43097000 & 2.52662000 & 6 & -0.43190500 & 3.69960600 & 2.30258300 \\
\hline 1 & -0.88252000 & 1.30806500 & 2.86665100 & 1 & -1.34596700 & 4.26865800 & 2.09601200 \\
\hline 6 & -1.21096900 & 4.43604300 & 1.58477800 & 1 & -0.20247100 & 3.72147400 & 3.37258900 \\
\hline 1 & -1.61411200 & 4.89359800 & -0.48121600 & 1 & 0.38168300 & 4.20260700 & 1.76015900 \\
\hline 1 & -0.83307600 & 3.67972100 & 3.57659300 & 6 & -4.26649900 & 0.03080500 & 0.19750500 \\
\hline 1 & -1.20421500 & 5.48504100 & 1.88858300 & 6 & -4.11904300 & 1.41956700 & 0.24439100 \\
\hline 6 & -2.67019800 & -0.36794000 & -0.67529200 & 6 & -4.89268900 & -0.55610100 & -0.90768300 \\
\hline 6 & -3.95922000 & -0.01322000 & -0.20834400 & 6 & -4.57059600 & 2.21107700 & -0.81024000 \\
\hline 6 & -2.52004100 & -1.03142800 & -1.90191100 & 1 & -3.63592700 & 1.89650000 & 1.09988600 \\
\hline 6 & -5.05540200 & -0.38340100 & -1.00038700 & 6 & -5.34234600 & 0.23777300 & -1.96055900 \\
\hline 6 & -3.62746400 & -1.38031800 & -2.66802300 & 1 & -5.01861700 & -1.64005600 & -0.94275000 \\
\hline 1 & -1.51496800 & -1.24169500 & -2.27631900 & 6 & -5.17916900 & 1.62223000 & -1.91680800 \\
\hline 6 & -4.90189200 & -1.05842800 & -2.20811200 & 1 & -4.44195800 & 3.29451200 & -0.76528100 \\
\hline 1 & -6.05966900 & -0.12591300 & -0.65290200 & 1 & -5.82892600 & -0.22924800 & -2.81972900 \\
\hline 1 & -3.49298800 & -1.89338200 & -3.62258700 & 1 & -5.53174200 & 2.24289600 & -2.74324600 \\
\hline 1 & -5.78324700 & -1.32615500 & -2.79473000 & 6 & -3.77648300 & -0.83313500 & 1.32963300 \\
\hline 6 & -4.20437800 & 0.76821000 & 1.04569300 & 8 & -3.49090600 & -2.15072400 & 0.86228200 \\
\hline 1 & -5.23168200 & 0.62447500 & 1.40369200 & 6 & -2.51185300 & -2.73008600 & 1.68511700 \\
\hline 1 & -3.52488700 & 0.50612700 & 1.86767700 & 6 & -1.72690000 & -1.56457700 & 2.22999100 \\
\hline 1 & -4.07583500 & 1.84983000 & 0.87598300 & 6 & -2.51934900 & -0.42425000 & 2.05020000 \\
\hline 6 & -1.77031000 & 2.47567400 & -1.61887500 & 1 & -2.95386700 & -3.27112300 & 2.54800400 \\
\hline 1 & -1.20625600 & 1.61831700 & -2.01507200 & 1 & -1.93863700 & -3.46409800 & 1.09999000 \\
\hline 1 & -2.83632500 & 2.23520100 & -1.76573900 & 1 & -1.02484700 & -1.66522200 & 3.06447500 \\
\hline 1 & -1.55021900 & 3.34246100 & -2.25552000 & 1 & -0.45529500 & -1.57471400 & 1.19399600 \\
\hline 6 & -1.12964500 & -1.06677900 & 1.71416400 & 1 & -4.57276800 & -0.88780500 & 2.11097000 \\
\hline 6 & 0.16456800 & -1.27228000 & 2.24991500 & 1 & -2.45171500 & 0.45958100 & 2.68654900 \\
\hline
\end{tabular}




\begin{tabular}{|c|c|c|c|c|c|c|c|}
\hline 6 & 2.08453500 & 1.27720100 & -1.23980500 & 6 & 0.12105800 & 1.52897700 & -1.68222100 \\
\hline 6 & 1.12064200 & 2.23464100 & -1.59843600 & 1 & 1.08003000 & 1.90945900 & -2.06366300 \\
\hline 6 & 3.43555300 & 1.43682000 & -1.63833800 & 1 & -0.51335700 & 1.25833200 & -2.54427200 \\
\hline 6 & 1.47171000 & 3.36257900 & -2.33188200 & 15 & -1.46193900 & 0.13015800 & 0.14396000 \\
\hline 1 & 0.08363400 & 2.10782400 & -1.28088400 & 6 & -1.78824300 & -0.64557800 & 1.75111200 \\
\hline 6 & 3.75247200 & 2.58686600 & -2.37463300 & 6 & -0.91028400 & -0.45811100 & 2.84780000 \\
\hline 6 & 2.79775100 & 3.54022900 & -2.71534100 & 6 & -2.88463500 & -1.51576200 & 1.86658000 \\
\hline 1 & 0.70951400 & 4.09636900 & -2.59986300 & 6 & -1.21951600 & -1.11887300 & 4.04332900 \\
\hline 1 & 4.78825100 & 2.72665600 & -2.69548500 & 6 & -3.15541400 & -2.16898100 & 3.06326500 \\
\hline 1 & 3.09245100 & 4.41987600 & -3.29142200 & 1 & -3.53815600 & -1.68229300 & 1.00639700 \\
\hline 6 & 2.65639500 & -0.79951500 & 0.85507400 & 6 & -2.32202100 & -1.95978100 & 4.15923300 \\
\hline 6 & 2.90024800 & -2.18282300 & 0.90713200 & 1 & -0.55728800 & -0.97577400 & 4.90117300 \\
\hline 6 & 3.27965300 & 0.07131900 & 1.78081500 & 1 & -4.01470500 & -2.83842900 & 3.13534500 \\
\hline 6 & 3.78170700 & -2.71400800 & 1.84193300 & 1 & -2.52341700 & -2.46306100 & 5.10770400 \\
\hline 1 & 2.39970700 & -2.85413900 & 0.20434000 & 6 & -2.82682800 & -0.29320100 & -0.99665800 \\
\hline 6 & 4.16199800 & -0.49664700 & 2.70893500 & 6 & -2.50252500 & -1.10437900 & -2.09605100 \\
\hline 6 & 4.41850400 & -1.86378900 & 2.74388200 & 6 & -4.14735800 & 0.19501600 & -0.83849400 \\
\hline 1 & 3.96835700 & -3.78926900 & 1.86451900 & 6 & -3.46652800 & -1.43346000 & -3.04495200 \\
\hline 1 & 4.65438300 & 0.16225800 & 3.42881200 & 1 & -1.48649600 & -1.49886400 & -2.20280000 \\
\hline 1 & 5.11289500 & -2.26743900 & 3.48362900 & 6 & -5.09212800 & -0.15553000 & -1.81016100 \\
\hline 6 & 4.54026100 & 0.47621600 & -1.31956500 & 6 & -4.76421700 & -0.95224700 & -2.90392400 \\
\hline 1 & 4.98628000 & 0.67182600 & -0.33146600 & 1 & -3.19491000 & -2.06838600 & -3.89052000 \\
\hline 1 & 4.22540300 & -0.57348300 & -1.30625000 & 1 & -6.11573500 & 0.21279300 & -1.69733800 \\
\hline 1 & 5.35273000 & 0.56745600 & -2.05093600 & 1 & -5.52965600 & -1.20070300 & -3.64287500 \\
\hline 6 & 3.07053500 & 1.55288100 & 1.79207000 & 46 & 0.56263400 & -0.28566200 & -0.75467500 \\
\hline 1 & 2.06283000 & 1.84302700 & 1.47596200 & 6 & 0.83354700 & -2.89190100 & -0.90618600 \\
\hline 1 & 3.22194700 & 1.95918700 & 2.79998000 & 8 & 1.00024100 & -2.22052600 & 0.16616100 \\
\hline 1 & 3.78053000 & 2.07155600 & 1.12741700 & 8 & 0.40105900 & -2.35224500 & -1.95338700 \\
\hline 6 & 1.07216000 & -1.45252400 & -1.57665700 & 6 & 1.21216800 & -4.34213500 & -0.89257900 \\
\hline 6 & -0.30285100 & -1.69926500 & -1.74133900 & 1 & 2.29112600 & -4.42440500 & -1.08274200 \\
\hline 6 & 2.01520800 & -2.14628700 & -2.34061500 & 1 & 0.68783400 & -4.89385000 & -1.68031300 \\
\hline 6 & -0.70911600 & -2.70760400 & -2.62726300 & 1 & 1.01949600 & -4.79362600 & 0.08741000 \\
\hline 6 & 1.59377500 & -3.12522000 & -3.23839000 & 16 & 3.44097100 & 0.84423200 & -0.53900000 \\
\hline 1 & 3.08370500 & -1.95428400 & -2.21773700 & 8 & 4.30134600 & 1.74915900 & -1.27603200 \\
\hline 6 & 0.23446400 & -3.41005700 & -3.37239500 & 8 & 2.53462800 & 1.46981200 & 0.49522900 \\
\hline 1 & -1.77449500 & -2.92154200 & -2.74503600 & 8 & 2.68275200 & -0.17069000 & -1.35769700 \\
\hline 1 & 2.33118000 & -3.68199800 & -3.81942300 & 6 & 4.54913200 & -0.22032900 & 0.49532700 \\
\hline 1 & -0.09366100 & -4.18920000 & -4.06349900 & 9 & 3.81241300 & -1.03488500 & 1.24161400 \\
\hline 6 & -1.30191700 & -0.85152000 & -1.05375100 & 9 & 5.29127300 & 0.54089700 & 1.28949700 \\
\hline 1 & -2.25990800 & -1.35517300 & -0.87229800 & 9 & 5.34460400 & -0.94225700 & -0.28052300 \\
\hline \multirow[t]{3}{*}{1} & -1.48039000 & 0.11807100 & -1.55196100 & 1 & 1.18033000 & 0.79558900 & 0.21256600 \\
\hline & & & & 6 & -4.57450500 & 1.06933300 & 0.29661300 \\
\hline & & & & 1 & -4.07720000 & 0.81413800 & 1.24219900 \\
\hline \multicolumn{2}{|c|}{ Pd-1-TS4 } & & & 1 & -5.65693300 & 0.99621200 & 0.46303700 \\
\hline
\end{tabular}




\begin{tabular}{|c|c|c|c|c|c|c|c|}
\hline 1 & -4.35203800 & 2.12869900 & 0.09390600 & 1 & 3.99320000 & -2.73171800 & -0.69831200 \\
\hline 6 & 0.34387000 & 0.34738100 & 2.76212600 & 1 & 2.16720300 & -2.38486500 & 1.08794800 \\
\hline 1 & 0.21118800 & 1.32165400 & 2.27053500 & 1 & 1.34093200 & 0.55961500 & 0.18678900 \\
\hline 1 & 1.11642000 & -0.19509300 & 2.19214200 & 1 & 3.29128500 & 1.08740600 & -1.07370600 \\
\hline 1 & 0.76156100 & 0.53791200 & 3.75824100 & 1 & 2.68648600 & 0.11827400 & 1.50819000 \\
\hline 6 & -0.55367900 & 2.47894400 & -0.74737200 & 6 & -1.77239300 & 1.65550900 & 1.26045300 \\
\hline 6 & -0.36562100 & 3.86325000 & -0.78939200 & 6 & -2.95788600 & 2.39177400 & 1.50733000 \\
\hline 6 & -1.38603200 & 1.94994400 & 0.25801500 & 6 & -0.64770300 & 1.85281700 & 2.08014700 \\
\hline 6 & -0.97591400 & 4.68855900 & 0.15546100 & 6 & -2.93223600 & 3.32601600 & 2.55346000 \\
\hline 1 & 0.29108900 & 4.29247000 & -1.55030400 & 6 & -0.65597600 & 2.78149500 & 3.11248500 \\
\hline 6 & -1.99034300 & 2.76987800 & 1.20975100 & 1 & 0.24517300 & 1.24419700 & 1.92041600 \\
\hline 6 & -1.77875500 & 4.14773700 & 1.15916200 & 6 & -1.80729600 & 3.52982500 & 3.34327700 \\
\hline 1 & -0.79979200 & 5.76622300 & 0.12357000 & 1 & -3.83839100 & 3.90531600 & 2.75047000 \\
\hline 1 & -2.58968400 & 2.33526200 & 2.01489300 & 1 & 0.22829100 & 2.91178500 & 3.73855100 \\
\hline \multirow[t]{3}{*}{1} & -2.22351000 & 4.79573700 & 1.91716100 & 1 & -1.83493100 & 4.26624300 & 4.14891600 \\
\hline & & & & 6 & -3.02974300 & -0.68860900 & 0.05994900 \\
\hline & & & & 6 & -3.56292100 & -1.42846400 & -1.02160500 \\
\hline \multicolumn{2}{|c|}{ Pd-1-TS5 } & & & 6 & -3.50864100 & -0.89780600 & 1.36588400 \\
\hline 15 & -1.62071800 & 0.44361200 & -0.09475600 & 6 & -4.61645500 & -2.30855800 & -0.74699000 \\
\hline 46 & 0.42778900 & -0.72184300 & -0.03706000 & 6 & -4.54696300 & -1.78946500 & 1.60752600 \\
\hline 6 & -0.73134800 & -2.71257100 & 1.11522100 & 1 & -3.06198100 & -0.35503900 & 2.20349300 \\
\hline 8 & -0.58606100 & -2.65051800 & -0.15057100 & 6 & -5.11251900 & -2.48685400 & 0.54187200 \\
\hline 8 & -0.25838200 & -1.78621100 & 1.83944200 & 1 & -5.04937300 & -2.87649100 & -1.57437600 \\
\hline 6 & -1.43182800 & -3.87925400 & 1.71868700 & 1 & -4.91205800 & -1.93665900 & 2.62592500 \\
\hline 1 & -0.71104600 & -4.69478300 & 1.87011100 & 1 & -5.93466700 & -3.18454300 & 0.71464400 \\
\hline 1 & -1.85625900 & -3.61916900 & 2.69422800 & 6 & -3.04015000 & -1.31737100 & -2.41655800 \\
\hline 1 & -2.21203100 & -4.25231700 & 1.04575600 & 1 & -3.28482800 & -0.35271400 & -2.88625400 \\
\hline 6 & 4.99194000 & 0.32748200 & 0.01127700 & 1 & -1.94617800 & -1.42094500 & -2.44208900 \\
\hline 6 & 5.19607000 & 1.30817000 & 0.99036600 & 1 & -3.45498500 & -2.10493200 & -3.05641100 \\
\hline 6 & 6.06569800 & -0.46521900 & -0.40062300 & 6 & -4.25349200 & 2.22544200 & 0.77213400 \\
\hline 6 & 6.45444800 & 1.48746000 & 1.55721200 & 1 & -4.20130500 & 1.58132300 & -0.11130400 \\
\hline 1 & 4.36618700 & 1.95021100 & 1.30459700 & 1 & -5.01386100 & 1.77812800 & 1.43094500 \\
\hline 6 & 7.32537700 & -0.28455700 & 0.17030800 & 1 & -4.65478400 & 3.20021900 & 0.46002500 \\
\hline 1 & 5.91594900 & -1.20652900 & -1.18811200 & 6 & -0.33837900 & 0.97884700 & -2.42747500 \\
\hline 6 & 7.52175400 & 0.68612200 & 1.15071400 & 6 & -0.04787100 & 1.69663600 & -3.59547900 \\
\hline 1 & 6.60433100 & 2.25799100 & 2.31625800 & 6 & -1.47870000 & 1.33278700 & -1.67889500 \\
\hline 1 & 8.16146100 & -0.90463000 & -0.15988900 & 6 & -0.89232900 & 2.71544600 & -4.02904500 \\
\hline 1 & 8.50980600 & 0.82466600 & 1.59415700 & 1 & 0.84371500 & 1.44207000 & -4.17413600 \\
\hline 6 & 3.61193900 & 0.14877400 & -0.58642200 & 6 & -2.31562500 & 2.36619200 & -2.11109700 \\
\hline 8 & 3.53563400 & -0.87425500 & -1.56522200 & 6 & -2.02719000 & 3.04876500 & -3.29085000 \\
\hline 6 & 3.12753300 & -2.08809700 & -0.96029200 & 1 & -0.65379900 & 3.26389600 & -4.94264100 \\
\hline 6 & 2.42033000 & -1.68345400 & 0.29013100 & 1 & -3.18117400 & 2.66850700 & -1.52084600 \\
\hline 6 & 2.65470200 & -0.31584100 & 0.50258500 & 1 & -2.67718300 & 3.86217300 & -3.61847100 \\
\hline 1 & 2.51647700 & -2.65996000 & -1.67702500 & 6 & 0.50905700 & -0.17685900 & -2.04220900 \\
\hline
\end{tabular}




\begin{tabular}{|c|c|c|c|c|c|c|c|}
\hline 1 & 1.56122200 & -0.07749300 & -2.34152700 & 6 & -4.93879600 & 2.13866600 & 2.14071100 \\
\hline \multirow[t]{3}{*}{1} & 0.12286100 & -1.14026800 & -2.42027900 & 1 & -5.57023900 & 0.19557400 & 2.85138800 \\
\hline & & & & 1 & -4.10307300 & 3.92243300 & 1.27237800 \\
\hline & & & & 1 & -5.67075100 & 2.68897000 & 2.73545600 \\
\hline \multicolumn{2}{|c|}{ Pd-1-TS6 } & & & 6 & 5.10254800 & 0.10779500 & -0.29836200 \\
\hline 6 & -0.72399500 & -1.82653400 & 1.85996900 & 6 & 5.56490300 & 1.15711900 & -1.09663200 \\
\hline 1 & -1.31341000 & -1.18177200 & 2.53371100 & 6 & 6.00766000 & -0.86362500 & 0.14877000 \\
\hline 1 & -0.01691900 & -2.42999400 & 2.44803500 & 6 & 6.91527800 & 1.24346200 & -1.43314200 \\
\hline 15 & -1.77582400 & -0.17569900 & -0.27139000 & 1 & 4.86136000 & 1.91406000 & -1.45458000 \\
\hline 46 & 0.32556300 & -0.27503200 & 0.93029600 & 6 & 7.35293300 & -0.78346100 & -0.19531300 \\
\hline 6 & 0.51369000 & 2.20365400 & 1.55247200 & 1 & 5.65318400 & -1.69739400 & 0.76231900 \\
\hline 8 & 1.05833700 & 1.81898300 & 0.47544200 & 6 & 7.80931500 & 0.27387900 & -0.98380700 \\
\hline 8 & -0.10349100 & 1.35394200 & 2.27531400 & 1 & 7.26862800 & 2.06966200 & -2.05343000 \\
\hline 6 & 0.59682100 & 3.62067000 & 1.99979200 & 1 & 8.05075500 & -1.54776200 & 0.15289700 \\
\hline 1 & 1.43018900 & 3.72570200 & 2.70865700 & 1 & 8.86628500 & 0.33935300 & -1.25015700 \\
\hline 1 & 0.78515000 & 4.29054000 & 1.15416200 & 6 & -2.19330900 & 2.97021200 & -0.34909100 \\
\hline 1 & -0.31510500 & 3.91534400 & 2.53213400 & 1 & -1.16537600 & 2.58301000 & -0.39727700 \\
\hline 6 & 3.66428700 & 0.03381200 & 0.10057600 & 1 & -2.55581600 & 2.99118700 & -1.39001800 \\
\hline 8 & 3.11162200 & -1.27583500 & -0.30839300 & 1 & -2.13973600 & 4.01500000 & -0.01735800 \\
\hline 6 & 2.20940800 & -1.66858800 & 0.59621600 & 6 & -4.26010100 & 0.49377900 & -2.27610400 \\
\hline 6 & 2.22564000 & -0.85217200 & 1.78150900 & 1 & -4.42387900 & -0.27414300 & -1.50918100 \\
\hline 6 & 3.36592800 & 0.10164400 & 1.60127100 & 1 & -4.53683500 & 1.45072500 & -1.80428300 \\
\hline 1 & 0.94557700 & -1.45788500 & -0.02594700 & 1 & -4.98255900 & 0.32142700 & -3.08356100 \\
\hline 1 & 2.01205800 & -2.75078200 & 0.60477800 & 6 & -1.52575800 & -2.61713900 & 0.90207600 \\
\hline 1 & 1.97784900 & -1.26825300 & 2.76211700 & 6 & -1.65711000 & -4.00612600 & 1.01629100 \\
\hline 1 & 3.16415700 & 1.12997300 & 1.92982000 & 6 & -2.18640800 & -1.95237200 & -0.15433500 \\
\hline 1 & 3.07020300 & 0.79289900 & -0.43425600 & 6 & -2.44970800 & -4.71548600 & 0.11295600 \\
\hline 1 & 4.22733500 & -0.24908100 & 2.19859000 & 1 & -1.14106500 & -4.53393900 & 1.82262400 \\
\hline 6 & -1.70790700 & 0.27938500 & -2.02556400 & 6 & -2.95953900 & -2.66760600 & -1.06590000 \\
\hline 6 & -0.42707800 & 0.37446600 & -2.59396000 & 6 & -3.09751600 & -4.05175000 & -0.92596600 \\
\hline 6 & -2.86061700 & 0.52695200 & -2.80995700 & 1 & -2.54388900 & -5.79870700 & 0.21119300 \\
\hline 6 & -0.26318400 & 0.69882100 & -3.93561900 & 1 & -3.42251900 & -2.16255000 & -1.91732800 \\
\hline 1 & 0.45574500 & 0.20159800 & -1.96897600 & 1 & -3.69100900 & -4.61294700 & -1.65005400 \\
\hline 6 & -2.66070700 & 0.85486000 & -4.15798700 & & & & \\
\hline 6 & -1.38936900 & 0.94194100 & -4.71798700 & & & & \\
\hline 1 & 0.73808600 & 0.76651200 & -4.36450400 & $\mathrm{Pd}-2-1$ & & & \\
\hline 1 & -3.53696300 & 1.04652000 & -4.78287900 & 46 & -0.58502600 & 1.09938100 & -0.50126600 \\
\hline 1 & -1.27962600 & 1.20112000 & -5.77314900 & 6 & -2.93878800 & 1.26228200 & -3.38510600 \\
\hline 6 & -3.05784500 & 0.75863300 & 0.60652100 & 6 & -3.97144400 & 1.39069300 & -2.45457600 \\
\hline 6 & -3.94377600 & 0.06430700 & 1.44474100 & 6 & -3.98486300 & 0.60760600 & -1.30218500 \\
\hline 6 & -3.09638000 & 2.17134000 & 0.53879400 & 6 & -2.96668500 & -0.32784500 & -1.09387500 \\
\hline 6 & -4.88383800 & 0.74870600 & 2.20771500 & 6 & -1.94450700 & -0.50172300 & -2.04226200 \\
\hline 1 & -3.90970000 & -1.02806200 & 1.49223100 & 6 & -1.93217300 & 0.32167000 & -3.17722400 \\
\hline 6 & -4.05520600 & 2.83107100 & 1.31647800 & 1 & -2.92327400 & 1.88920800 & -4.27916800 \\
\hline
\end{tabular}




\begin{tabular}{|c|c|c|c|c|c|c|c|}
\hline 1 & -4.76940000 & 2.11996300 & -2.61420500 & 1 & 4.86241700 & -2.66114400 & 0.33017800 \\
\hline 1 & -4.76925900 & 0.73983800 & -0.55566100 & 6 & 0.86174500 & -1.28469600 & 1.32534700 \\
\hline 1 & -1.20811700 & -1.30061900 & -1.93239200 & 6 & 0.42890800 & -0.64539100 & 2.50391400 \\
\hline 1 & -1.13698300 & 0.19695900 & -3.91721900 & 6 & 0.65049900 & -2.67768900 & 1.19482000 \\
\hline 6 & -1.96341800 & 2.39221900 & 2.11499600 & 6 & -0.13449900 & -1.34775200 & 3.56112700 \\
\hline 6 & -0.65120100 & 3.13077800 & 1.87650700 & 1 & 0.52459000 & 0.44179600 & 2.57998700 \\
\hline 6 & -0.56761500 & 3.08980100 & 0.37149600 & 6 & 0.09031500 & -3.36764100 & 2.28172700 \\
\hline 6 & -1.86272800 & 2.82909800 & -0.08853000 & 6 & -0.29337600 & -2.72863700 & 3.45554600 \\
\hline 8 & -2.75559400 & 2.61279100 & 0.94426200 & 1 & -0.45588900 & -0.81437500 & 4.45901900 \\
\hline 1 & -2.54034700 & 2.73174600 & 2.98584900 & 1 & -0.06638800 & -4.44584600 & 2.18144400 \\
\hline 1 & -1.78164700 & 1.30165500 & 2.21777200 & 1 & -0.73247800 & -3.30298700 & 4.27470500 \\
\hline 1 & 0.19942000 & 2.66782200 & 2.40093300 & 6 & 0.92839800 & -3.45249200 & -0.05689200 \\
\hline 1 & -0.70404700 & 4.17962700 & 2.22455800 & 1 & 0.51692600 & -2.96136400 & -0.95056500 \\
\hline 1 & 0.16208800 & 3.68610500 & -0.18221300 & 1 & 2.00223100 & -3.59029600 & -0.25200000 \\
\hline 1 & -2.33789700 & 3.14905600 & -1.02063200 & 1 & 0.47934200 & -4.45223800 & 0.00379100 \\
\hline 53 & -2.98629000 & -1.53466500 & 0.64813200 & & & & \\
\hline 15 & 1.34163600 & -0.12485700 & -0.01940500 & & & & \\
\hline 6 & 2.33835500 & -1.00773400 & -1.29908700 & $\mathrm{Pd}-2-2$ & & & \\
\hline 6 & 2.62974500 & 0.98232800 & 0.71457300 & 46 & 1.18945600 & 0.38893100 & 0.26767600 \\
\hline 6 & 3.56566800 & -1.67135700 & -1.07187300 & 6 & 5.99837300 & -0.03376900 & 0.92237600 \\
\hline 6 & 1.83306000 & -0.92398300 & -2.60398200 & 6 & 5.50115600 & 0.27654400 & -0.34263400 \\
\hline 6 & 3.13371000 & 0.81803200 & 2.01328700 & 6 & 4.12596600 & 0.40774300 & -0.54857700 \\
\hline 6 & 3.09013700 & 2.07555800 & -0.06411600 & 6 & 3.23516400 & 0.22853200 & 0.51091000 \\
\hline 6 & 4.22037100 & -2.24164000 & -2.17232500 & 6 & 3.73399900 & -0.08864000 & 1.77781700 \\
\hline 6 & 2.49866300 & -1.49614400 & -3.68432500 & 6 & 5.11062200 & -0.21601900 & 1.98184400 \\
\hline 1 & 0.89694800 & -0.37457400 & -2.75725100 & 1 & 7.07443900 & -0.13896000 & 1.08059500 \\
\hline 6 & 4.04271300 & 1.71797100 & 2.56336400 & 1 & 6.18771900 & 0.41376600 & -1.18286800 \\
\hline 1 & 2.82377400 & -0.04331900 & 2.60953200 & 1 & 3.75629000 & 0.64444000 & -1.55088000 \\
\hline 6 & 3.99906500 & 2.97161400 & 0.51438100 & 1 & 3.05093100 & -0.25386700 & 2.61789000 \\
\hline 6 & 3.70168000 & -2.16149600 & -3.46237000 & 1 & 5.48703000 & -0.46827400 & 2.97745200 \\
\hline 1 & 5.16419600 & -2.76927400 & -2.00448300 & 6 & 1.71543000 & 3.19109700 & -1.54859300 \\
\hline 1 & 2.08273500 & -1.41906900 & -4.69159700 & 6 & 0.42849300 & 3.34373300 & -0.75778700 \\
\hline 6 & 4.47103100 & 2.80994400 & 1.81311900 & 6 & 0.81023200 & 2.65053700 & 0.52774100 \\
\hline 1 & 4.41676500 & 1.55972800 & 3.57779800 & 6 & 2.18771200 & 2.69350300 & 0.56981800 \\
\hline 1 & 4.34488800 & 3.81939600 & -0.08460700 & 8 & 2.76077400 & 3.12837600 & -0.55564500 \\
\hline 1 & 4.24074800 & -2.62091800 & -4.29449700 & 1 & 1.95776900 & 4.00376000 & -2.24291000 \\
\hline 1 & 5.17729700 & 3.52997900 & 2.23324100 & 1 & 1.73202000 & 2.22871800 & -2.09645900 \\
\hline 6 & 2.67100900 & 2.28700000 & -1.48336300 & 1 & -0.44492800 & 2.92838700 & -1.27702200 \\
\hline 1 & 2.92628000 & 3.29737000 & -1.82930600 & 1 & 0.19141900 & 4.40394400 & -0.55313100 \\
\hline 1 & 3.16637500 & 1.57413100 & -2.16211900 & 1 & 0.20285000 & 2.68989600 & 1.43068000 \\
\hline 1 & 1.58504800 & 2.13481000 & -1.61673300 & 1 & 2.86059800 & 2.57234100 & 1.41645900 \\
\hline 6 & 4.18169900 & -1.80048800 & 0.28520100 & 53 & 1.47466800 & -2.22595500 & -0.34542100 \\
\hline 1 & 4.77338000 & -0.90859100 & 0.54523000 & 15 & -1.26501000 & 0.03851100 & -0.00463500 \\
\hline 1 & 3.43223300 & -1.91761200 & 1.08093400 & 6 & -2.05544400 & -1.05534900 & 1.24144900 \\
\hline
\end{tabular}




\begin{tabular}{|c|c|c|c|c|c|c|c|}
\hline 6 & -2.33732900 & 1.53846900 & 0.10851600 & 6 & -4.62727300 & -0.74359800 & -1.45651800 \\
\hline 6 & -3.45297800 & -1.25479800 & 1.33114400 & 6 & -4.83927300 & -0.16653200 & -0.20357400 \\
\hline 6 & -1.20924600 & -1.63005400 & 2.20011800 & 6 & -4.10787600 & 0.94835300 & 0.18943000 \\
\hline 6 & -3.01865700 & 2.05901200 & -1.00204800 & 6 & -3.14450300 & 1.50298000 & -0.66801400 \\
\hline 6 & -2.42909700 & 2.21952800 & 1.34909100 & 6 & -2.93037200 & 0.90521500 & -1.92947600 \\
\hline 6 & -3.93673500 & -2.04392400 & 2.38356300 & 6 & -3.67500800 & -0.20887200 & -2.31956700 \\
\hline 6 & -1.71390500 & -2.40844900 & 3.23655700 & 1 & -5.19986600 & -1.62405500 & -1.75525200 \\
\hline 1 & -0.13125100 & -1.45812800 & 2.12446500 & 1 & -5.57607200 & -0.59833000 & 0.47676600 \\
\hline 6 & -3.75569300 & 3.23612400 & -0.92025800 & 1 & -4.27574100 & 1.42202800 & 1.15857200 \\
\hline 1 & -2.99470700 & 1.52169100 & -1.95261100 & 1 & -2.21582900 & 1.35894500 & -2.62494600 \\
\hline 6 & -3.17057300 & 3.40824600 & 1.40320600 & 1 & -3.49959800 & -0.66479200 & -3.29692800 \\
\hline 6 & -3.08776100 & -2.61658300 & 3.32659900 & 6 & -1.77326300 & 3.01147800 & 1.89176600 \\
\hline 1 & -5.01504100 & -2.21427100 & 2.45480300 & 6 & -0.49604000 & 3.13528700 & 1.09061200 \\
\hline 1 & -1.03330100 & -2.85054200 & 3.96710900 & 6 & -0.89925800 & 2.50279900 & -0.22420500 \\
\hline 6 & -3.82463000 & 3.92353500 & 0.28875300 & 6 & -2.40166600 & 2.78858100 & -0.30771500 \\
\hline 1 & -4.27981400 & 3.61054200 & -1.80272400 & 8 & -2.80115200 & 3.28404500 & 0.95533500 \\
\hline 1 & -3.23566100 & 3.93691700 & 2.35899200 & 1 & -1.87253200 & 3.72288300 & 2.72326200 \\
\hline 1 & -3.50261800 & -3.22847800 & 4.13138600 & 1 & -1.87797200 & 1.98424700 & 2.30557300 \\
\hline 1 & -4.39330100 & 4.85286600 & 0.36806100 & 1 & 0.38108400 & 2.68233900 & 1.57473600 \\
\hline 6 & -1.81977700 & 1.70447300 & 2.61885400 & 1 & -0.24933800 & 4.20334200 & 0.93935600 \\
\hline 1 & -1.66472700 & 2.51841300 & 3.34006300 & 1 & -0.32613000 & 2.84611400 & -1.09543200 \\
\hline 1 & -2.47285800 & 0.96231100 & 3.10655600 & 1 & -2.65001700 & 3.56284100 & -1.05976600 \\
\hline 1 & -0.85581800 & 1.19541200 & 2.46648500 & 53 & -1.70195100 & -2.22726800 & 0.42908600 \\
\hline 6 & -4.43969100 & -0.67507900 & 0.36408700 & 15 & 1.22517900 & 0.00662000 & 0.05760400 \\
\hline 1 & -4.75208000 & 0.33987100 & 0.65831700 & 6 & 2.16537600 & -0.86267300 & -1.27061700 \\
\hline 1 & -4.04470000 & -0.59272600 & -0.65812300 & 6 & 2.26640000 & 1.53039400 & 0.14942800 \\
\hline 1 & -5.35028600 & -1.28833600 & 0.32355400 & 6 & 3.55432200 & -0.90035800 & -1.06173500 \\
\hline 6 & -1.50561100 & -0.60491300 & -1.71166500 & 6 & 1.62346300 & -1.39413000 & -2.46113200 \\
\hline 6 & -1.03324900 & 0.28491100 & -2.69285000 & 6 & 2.97426500 & 1.88976500 & 1.30564100 \\
\hline 6 & -1.93071800 & -1.89541500 & -2.10648800 & 6 & 2.32377400 & 2.38025200 & -0.98402600 \\
\hline 6 & -1.03141500 & -0.03238700 & -4.04436900 & 6 & 4.41495300 & -1.48039200 & -1.98498700 \\
\hline 1 & -0.64254900 & 1.25771600 & -2.37798500 & 1 & 3.97030000 & -0.47166800 & -0.14475800 \\
\hline 6 & -1.91927100 & -2.19032300 & -3.48010000 & 6 & 2.51647200 & -1.97447600 & -3.37797000 \\
\hline 6 & -1.49108300 & -1.28505900 & -4.44260900 & 6 & 3.67850200 & 3.08870900 & 1.38329100 \\
\hline 1 & -0.65742900 & 0.68716700 & -4.77584200 & 1 & 2.98701600 & 1.21879600 & 2.16592200 \\
\hline 1 & -2.24275600 & -3.18756300 & -3.79124800 & 6 & 3.02085500 & 3.59013900 & -0.87198500 \\
\hline 1 & -1.49307900 & -1.56622800 & -5.49803800 & 6 & 3.88678900 & -2.02697100 & -3.15296100 \\
\hline 6 & -2.33970200 & -2.99237700 & -1.17230400 & 1 & 5.49005000 & -1.50001900 & -1.79382200 \\
\hline 1 & -1.63242800 & -3.11319500 & -0.34070500 & 1 & 2.10803400 & -2.38861700 & -4.30401800 \\
\hline 1 & -3.33641300 & -2.83712700 & -0.73487000 & 6 & 3.68320600 & 3.95605000 & 0.29568200 \\
\hline \multirow[t]{2}{*}{1} & -2.37624600 & -3.94741100 & -1.71149700 & 1 & 4.22041200 & 3.34002000 & 2.29784100 \\
\hline & & & & 1 & 3.04975800 & 4.25573400 & -1.73962900 \\
\hline \multicolumn{2}{|c|}{ Pd-2-3 } & & & 1 & 4.54446900 & -2.48396400 & -3.89616100 \\
\hline 46 & -1.01246900 & 0.40728300 & -0.15153700 & 1 & 4.21623400 & 4.90832000 & 0.34718800 \\
\hline
\end{tabular}




\begin{tabular}{|c|c|c|c|c|c|c|c|}
\hline 6 & 1.73842000 & 2.01967400 & -2.31472800 & 1 & 0.57300100 & 1.34336000 & 2.21308700 \\
\hline 1 & 1.51440500 & 2.91799300 & -2.90591800 & 1 & 1.32822700 & 1.11731800 & 3.77811100 \\
\hline 1 & 2.44669200 & 1.41382600 & -2.90328800 & 1 & 2.61986900 & -0.77554300 & 2.71410600 \\
\hline 1 & 0.81493100 & 1.42760700 & -2.23385700 & 1 & 4.43582600 & 0.86127600 & 2.27820300 \\
\hline 6 & 0.17165900 & -1.37204300 & -2.80991100 & 53 & 1.42591800 & -2.25422300 & -0.27365700 \\
\hline 1 & -0.29215400 & -0.39032500 & -2.62440600 & 15 & -1.23594200 & 0.55425700 & -0.29601500 \\
\hline 1 & 0.02103400 & -1.62476400 & -3.86758200 & 6 & -2.65597100 & 0.84752300 & 0.83410000 \\
\hline 1 & -0.41075300 & -2.08541400 & -2.20403900 & 6 & -0.92871600 & 2.14776600 & -1.17064700 \\
\hline 6 & 1.48938100 & -0.88453600 & 1.64247300 & 6 & -1.80347200 & -0.56982300 & -1.68679400 \\
\hline 6 & 1.84553100 & -2.24486600 & 1.79784800 & 6 & -3.33185200 & 2.07653300 & 0.86870600 \\
\hline 6 & 1.11117200 & -0.14029000 & 2.77430900 & 6 & -3.00303100 & -0.15910500 & 1.77283700 \\
\hline 6 & 1.88826700 & -2.75567900 & 3.10520200 & 6 & -1.81659300 & 2.79593000 & -2.06441100 \\
\hline 6 & 1.15257900 & -0.67502300 & 4.05430000 & 6 & 0.33736800 & 2.71661500 & -0.94356400 \\
\hline 1 & 0.75427500 & 0.88584100 & 2.64182900 & 1 & -2.17312300 & 0.07941200 & -2.49194700 \\
\hline 6 & 1.56091500 & -1.99597700 & 4.22071200 & 1 & -0.86560700 & -1.02040100 & -2.04764200 \\
\hline 1 & 2.15955200 & -3.80704200 & 3.23481700 & 6 & -2.80580300 & -1.63920500 & -1.37871300 \\
\hline 1 & 0.85037700 & -0.06858300 & 4.91049100 & 6 & -4.37904800 & 2.30535300 & 1.75779900 \\
\hline 1 & 1.59584100 & -2.44460600 & 5.21613200 & 1 & -3.03218700 & 2.88016600 & 0.19213300 \\
\hline 6 & 2.10195100 & -3.19995800 & 0.67383900 & 6 & -4.07346200 & 0.08923300 & 2.64112900 \\
\hline 1 & 1.35700700 & -3.09079300 & -0.12620400 & 6 & -1.38786900 & 3.98068200 & -2.68110100 \\
\hline 1 & 3.09364800 & -3.07641500 & 0.21484700 & 6 & 0.74190100 & 3.89149000 & -1.56771800 \\
\hline \multirow[t]{3}{*}{1} & 2.03710000 & -4.23273500 & 1.03860800 & 1 & 1.03833300 & 2.21053400 & -0.26839700 \\
\hline & & & & 6 & -2.43069300 & -2.98987600 & -1.40615400 \\
\hline & & & & 6 & -4.13260800 & -1.32231000 & -1.05181900 \\
\hline Pd-2-4 & & & & 6 & -4.76563500 & 1.29699800 & 2.63536900 \\
\hline 46 & 0.76250800 & 0.01777900 & 0.91967600 & 1 & -4.89087600 & 3.27046000 & 1.75832100 \\
\hline 6 & 5.26618600 & -1.02032000 & -2.02106700 & 1 & -4.35852700 & -0.69285200 & 3.35064000 \\
\hline 6 & 4.36972700 & 0.03969800 & -2.14505500 & 6 & -0.13004700 & 4.52699800 & -2.44732000 \\
\hline 6 & 3.84542200 & 0.65363800 & -1.01010600 & 1 & -2.07386100 & 4.48593700 & -3.36759200 \\
\hline 6 & 4.22117500 & 0.21670400 & 0.26200000 & 1 & 1.73724800 & 4.29628400 & -1.36814700 \\
\hline 6 & 5.13146000 & -0.83626400 & 0.38071200 & 6 & -3.34881100 & -3.99140400 & -1.09875300 \\
\hline 6 & 5.64661800 & -1.45809600 & -0.75338300 & 1 & -1.39552500 & -3.24652600 & -1.64973300 \\
\hline 1 & 5.67035200 & -1.50525900 & -2.91286600 & 6 & -5.04982500 & -2.32270200 & -0.73852100 \\
\hline 1 & 4.06814100 & 0.38762400 & -3.13599600 & 1 & -4.45106900 & -0.27605000 & -1.02161400 \\
\hline 1 & 3.13755100 & 1.47976600 & -1.10564100 & 1 & -5.59398300 & 1.45489400 & 3.33006200 \\
\hline 1 & 5.43371700 & -1.17831700 & 1.37575100 & 1 & 0.16534100 & 5.44931700 & -2.95325600 \\
\hline 1 & 6.35046900 & -2.28688900 & -0.64673300 & 6 & -4.65975500 & -3.66145800 & -0.75571000 \\
\hline 6 & 2.41353900 & 2.49938500 & 2.38578700 & 1 & -3.03477300 & -5.03764100 & -1.12079700 \\
\hline 6 & 1.62126600 & 1.23849900 & 2.72493800 & 1 & -6.07597300 & -2.05304100 & -0.47658000 \\
\hline 6 & 2.42873300 & 0.13361600 & 2.13287000 & 1 & -5.37815500 & -4.44644700 & -0.50744300 \\
\hline 6 & 3.63534600 & 0.82311100 & 1.50108800 & 6 & -3.19178300 & 2.30028200 & -2.40146900 \\
\hline 8 & 3.17854900 & 2.15210300 & 1.26124600 & 1 & -3.21546500 & 1.81744300 & -3.39186200 \\
\hline 1 & 3.06640400 & 2.76167300 & 3.24334200 & 1 & -3.58543400 & 1.57843100 & -1.67797700 \\
\hline 1 & 1.80308500 & 3.37942300 & 2.13968700 & 1 & -3.90524600 & 3.13497200 & -2.45212200 \\
\hline
\end{tabular}




\begin{tabular}{|c|c|c|c|c|c|c|c|}
\hline 6 & -2.24181300 & -1.43996200 & 1.90944500 & 6 & -4.15795100 & 0.04544900 & 2.50312400 \\
\hline 1 & -2.08466600 & -1.96855600 & 0.95934900 & 6 & -1.12938300 & 4.11881400 & -2.49603300 \\
\hline 1 & -1.23051900 & -1.25943200 & 2.31554300 & 6 & 0.94697500 & 3.99405000 & -1.29314800 \\
\hline \multirow[t]{3}{*}{1} & -2.75257200 & -2.13323300 & 2.59016000 & 1 & 1.16539500 & 2.29342900 & 0.00047000 \\
\hline & & & & 6 & -2.39234800 & -2.83239100 & -1.51869700 \\
\hline & & & & 6 & -4.04204900 & -1.10072000 & -1.24225900 \\
\hline Pd-2-5 & & & & 6 & -4.83889400 & 1.25879300 & 2.50726900 \\
\hline 46 & 0.72112700 & 0.01273800 & 1.08550300 & 1 & -4.88176400 & 3.27845100 & 1.73175800 \\
\hline 6 & 4.77565400 & -0.61777400 & -2.52944200 & 1 & -4.50449000 & -0.77081400 & 3.14320500 \\
\hline 6 & 4.04022100 & 0.53865600 & -2.27913900 & 6 & 0.11903800 & 4.65267800 & -2.19686400 \\
\hline 6 & 3.73275800 & 0.90592700 & -0.97009200 & 1 & -1.78415800 & 4.64300200 & -3.19843400 \\
\hline 6 & 4.15638200 & 0.11745000 & 0.10082700 & 1 & 1.93262000 & 4.39171500 & -1.04038300 \\
\hline 6 & 4.90875700 & -1.03212500 & -0.15516600 & 6 & -3.37965800 & -3.79980600 & -1.34767600 \\
\hline 6 & 5.21317000 & -1.40136500 & -1.46193800 & 1 & -1.35223200 & -3.13019600 & -1.67813200 \\
\hline 1 & 5.01207000 & -0.90798600 & -3.55584400 & 6 & -5.03004200 & -2.06762900 & -1.06790200 \\
\hline 1 & 3.70094700 & 1.16366300 & -3.10925500 & 1 & -4.31809600 & -0.04341600 & -1.19084800 \\
\hline 1 & 3.16562300 & 1.81561800 & -0.76905900 & 1 & -5.72049600 & 1.38764200 & 3.13953900 \\
\hline 1 & 5.24774800 & -1.65464000 & 0.67932300 & 1 & 0.44051200 & 5.58443500 & -2.66823700 \\
\hline 1 & 5.79141800 & -2.30919600 & -1.64896600 & 6 & -4.70139100 & -3.42179400 & -1.11435700 \\
\hline 6 & 2.54694300 & 1.90329900 & 2.78279000 & 1 & -3.11118400 & -4.85796200 & -1.39218400 \\
\hline 6 & 1.90834300 & 0.54596500 & 2.90987100 & 1 & -6.06349000 & -1.75855400 & -0.89268700 \\
\hline 6 & 2.66822100 & -0.33817100 & 2.16408000 & 1 & -5.47519500 & -4.18029600 & -0.97395100 \\
\hline 6 & 3.78679500 & 0.45693600 & 1.51634800 & 6 & -2.95168600 & 2.44719700 & -2.33892200 \\
\hline 8 & 3.35387800 & 1.80604300 & 1.63047800 & 1 & -2.93308700 & 1.98860400 & -3.34085500 \\
\hline 1 & 3.16487100 & 2.09623100 & 3.68730400 & 1 & -3.38695000 & 1.71279600 & -1.65354700 \\
\hline 1 & 1.85960300 & 2.75292300 & 2.66597500 & 1 & -3.65397900 & 3.29026800 & -2.40227200 \\
\hline 1 & 0.08811300 & 1.29613000 & 1.74742300 & 6 & -2.27465100 & -1.45462800 & 1.84739000 \\
\hline 1 & 1.27609200 & 0.27312400 & 3.75760600 & 1 & -1.90821000 & -1.87055000 & 0.89968700 \\
\hline 1 & 2.73092800 & -1.41754200 & 2.30815000 & 1 & -1.37548900 & -1.31493100 & 2.47328400 \\
\hline 1 & 4.68738800 & 0.30028000 & 2.15707500 & 1 & -2.89246300 & -2.22496700 & 2.32738000 \\
\hline 53 & 1.29191000 & -2.33266100 & -0.26031000 & & & & \\
\hline 15 & -1.12134800 & 0.64106000 & -0.19789200 & & & & \\
\hline 6 & -2.59645700 & 0.88613700 & 0.86486200 & Pd-2-6 & & & \\
\hline 6 & -0.74569300 & 2.25337900 & -1.00456300 & 46 & -0.55705800 & -1.06869900 & 0.18020300 \\
\hline 6 & -1.62621900 & -0.44106400 & -1.64471300 & 6 & -7.65185800 & 0.18497600 & 0.06732400 \\
\hline 6 & -3.26348000 & 2.11881800 & 0.90669400 & 6 & -6.91806300 & 1.29417200 & -0.34766800 \\
\hline 6 & -3.02162600 & -0.16684900 & 1.71166400 & 6 & -5.55151900 & 1.17985900 & -0.60307900 \\
\hline 6 & -1.59021900 & 2.92255300 & -1.92610200 & 6 & -4.90249800 & -0.04622700 & -0.43845300 \\
\hline 6 & 0.50995800 & 2.81142100 & -0.70705900 & 6 & -5.64750900 & -1.15855100 & -0.02727100 \\
\hline 1 & -1.89574100 & 0.25503800 & -2.45051000 & 6 & -7.01212300 & -1.04540500 & 0.22359700 \\
\hline 1 & -0.68781000 & -0.93011600 & -1.94884400 & 1 & -8.72268100 & 0.27566700 & 0.26382200 \\
\hline 6 & -2.70539900 & -1.46695200 & -1.45968200 & 1 & -7.41420900 & 2.25887100 & -0.48068100 \\
\hline 6 & -4.37747500 & 2.30961700 & 1.71935700 & 1 & -4.97600900 & 2.04057500 & -0.94978100 \\
\hline 1 & -2.90390200 & 2.95344900 & 0.30056800 & 1 & -5.15327300 & -2.12860600 & 0.08915300 \\
\hline
\end{tabular}




\begin{tabular}{|c|c|c|c|c|c|c|c|}
\hline 1 & -7.58144300 & -1.92269100 & 0.53997300 & 6 & 3.86193600 & 0.26618200 & 1.19503100 \\
\hline 6 & -2.20031500 & 1.63585300 & 0.00163000 & 6 & 4.84215400 & -1.14262800 & -0.97154700 \\
\hline 6 & -1.90493000 & 0.51121500 & 0.94521800 & 6 & 5.17434600 & -0.19246600 & 1.21376200 \\
\hline 6 & -2.66948000 & -0.58560000 & 0.55128100 & 1 & 3.49399400 & 0.84969400 & 2.04371100 \\
\hline 6 & -3.41873200 & -0.19536500 & -0.71105500 & 6 & 5.66552000 & -0.90776200 & 0.12399600 \\
\hline 8 & -2.80647000 & 1.02090200 & -1.12104400 & 1 & 5.22990200 & -1.70004700 & -1.82895500 \\
\hline 1 & -1.33000600 & 2.21853500 & -0.34176300 & 1 & 5.81027300 & 0.01321600 & 2.07759800 \\
\hline 1 & -2.89002100 & 2.35614500 & 0.49334300 & 1 & 6.69231600 & -1.28098700 & 0.12522500 \\
\hline 1 & -1.40906200 & -2.39045500 & 0.15105400 & 6 & 2.72278300 & -0.91232900 & -2.26763700 \\
\hline 1 & -1.58279000 & 0.70522500 & 1.97305900 & 1 & 1.65056200 & -1.05839500 & -2.07443000 \\
\hline 1 & -3.07968500 & -1.33024000 & 1.23449900 & 1 & 2.81425000 & -0.05781500 & -2.95941000 \\
\hline 1 & -3.27565800 & -0.92076200 & -1.53116900 & 1 & 3.07903000 & -1.80282700 & -2.80172200 \\
\hline 53 & 0.86320300 & -3.32594400 & -0.13116900 & & & & \\
\hline 15 & 1.28296900 & 0.61311700 & 0.09157400 & & & & \\
\hline 6 & 1.22418700 & 1.70224100 & -1.38608200 & Pd-2-7 & & & \\
\hline 6 & 1.09314900 & 1.69209200 & 1.56283500 & 46 & -0.09016800 & -0.97689000 & -0.89987000 \\
\hline 6 & 0.17319700 & 1.45603100 & -2.28263900 & 6 & -7.23035800 & 0.63312500 & 0.80470400 \\
\hline 6 & 2.21204900 & 2.66295900 & -1.71314700 & 6 & -7.05805700 & -0.21327100 & -0.28838600 \\
\hline 6 & 1.02194000 & 1.09946000 & 2.84966800 & 6 & -5.77807800 & -0.51723800 & -0.75165700 \\
\hline 6 & 0.84277600 & 3.06418600 & 1.42116100 & 6 & -4.65510500 & 0.02321600 & -0.12048300 \\
\hline 6 & 0.06614400 & 2.14617900 & -3.48522400 & 6 & -4.83389300 & 0.86927800 & 0.98113200 \\
\hline 1 & -0.57638600 & 0.69824600 & -2.02930500 & 6 & -6.11205300 & 1.17547000 & 1.43901200 \\
\hline 6 & 2.08233100 & 3.34379500 & -2.93236000 & 1 & -8.23447400 & 0.86846900 & 1.16533700 \\
\hline 6 & 0.75581000 & 1.93117600 & 3.94470600 & 1 & -7.92903100 & -0.64603900 & -0.78688600 \\
\hline 6 & 0.55280900 & 3.86404700 & 2.52461000 & 1 & -5.63841300 & -1.18301400 & -1.60466100 \\
\hline 1 & 0.86775300 & 3.51749200 & 0.42580400 & 1 & -3.95497100 & 1.29185200 & 1.48021500 \\
\hline 6 & 1.03191700 & 3.09487300 & -3.81126200 & 1 & -6.23726700 & 1.83924600 & 2.29800500 \\
\hline 1 & -0.76649200 & 1.93737000 & -4.15991000 & 6 & -2.03586600 & -1.10929300 & -2.30426600 \\
\hline 1 & 2.83826700 & 4.08970100 & -3.19481200 & 6 & -1.42261800 & 0.21402600 & -1.96969900 \\
\hline 6 & 0.52101200 & 3.29564900 & 3.79472700 & 6 & -2.48478100 & 0.91944500 & -1.16590300 \\
\hline 1 & 0.71663100 & 1.48359800 & 4.94209400 & 6 & -3.26506200 & -0.26225700 & -0.59530100 \\
\hline 1 & 0.36081700 & 4.93058400 & 2.38771200 & 8 & -3.26872600 & -1.21041100 & -1.65873500 \\
\hline 1 & 0.97065900 & 3.64505400 & -4.75339100 & 1 & -1.35658500 & -1.98797500 & -1.93396500 \\
\hline 1 & 0.30506800 & 3.91176300 & 4.67055600 & 1 & -2.13521500 & -1.35863000 & -3.37272700 \\
\hline 6 & 3.40153200 & 2.96134900 & -0.85381400 & 1 & -2.10793800 & 1.59670200 & -0.38693500 \\
\hline 1 & 4.23391300 & 2.27199600 & -1.06988600 & 1 & -0.95804500 & 0.78123900 & -2.78605200 \\
\hline 1 & 3.77304600 & 3.97801600 & -1.03994600 & 1 & -3.14094200 & 1.51770600 & -1.82569300 \\
\hline 1 & 3.19585800 & 2.86791900 & 0.22007300 & 1 & -2.66443400 & -0.68742800 & 0.24439400 \\
\hline 6 & 1.14648300 & -0.37627400 & 3.07161100 & 53 & 0.82465800 & -3.27734500 & 0.22411500 \\
\hline 1 & 1.92763600 & -0.85809900 & 2.46722300 & 15 & 1.21594700 & 0.64164900 & 0.01328600 \\
\hline 1 & 1.35089500 & -0.60440300 & 4.12565800 & 6 & 2.13568000 & 1.64902000 & -1.21938000 \\
\hline 1 & 0.20857200 & -0.89646700 & 2.80580300 & 6 & 0.13478600 & 1.80566600 & 0.93268800 \\
\hline 6 & 3.02132400 & 0.02507900 & 0.09871800 & 6 & 3.08516400 & 2.63882900 & -0.86389400 \\
\hline 6 & 3.51702600 & -0.68654300 & -1.01927500 & 6 & 1.93002100 & 1.34369900 & -2.57193200 \\
\hline
\end{tabular}




\begin{tabular}{|c|c|c|c|c|c|c|c|}
\hline 6 & -0.71974300 & 1.34969300 & 1.96692300 & 6 & -5.91241700 & -0.30882600 & -0.95659900 \\
\hline 6 & 0.02038600 & 3.13079200 & 0.47984100 & 6 & -4.86293000 & 0.054688800 & -0.10947900 \\
\hline 6 & 3.76444000 & 3.29470100 & -1.90033100 & 6 & -5.15650100 & 0.63767600 & 1.13018000 \\
\hline 6 & 2.62277500 & 2.00411000 & -3.58173900 & 6 & -6.47622900 & 0.85959500 & 1.51237500 \\
\hline 1 & 1.22876800 & 0.54274000 & -2.82441900 & 1 & -8.55750700 & 0.66528800 & 0.96212900 \\
\hline 6 & -1.61791600 & 2.26923800 & 2.53016400 & 1 & -8.04804200 & -0.38112200 & -1.23801100 \\
\hline 6 & -0.89258900 & 4.01482600 & 1.04471200 & 1 & -5.68600100 & -0.76906400 & -1.91994300 \\
\hline 1 & 0.65124600 & 3.47837200 & -0.34203800 & 1 & -4.33708200 & 0.91720300 & 1.80156600 \\
\hline 6 & 3.54387700 & 2.99007900 & -3.24035100 & 1 & -6.69139800 & 1.31577200 & 2.48164900 \\
\hline 1 & 4.49211900 & 4.06774500 & -1.63729600 & 6 & -2.07981100 & -0.50211000 & -2.22783900 \\
\hline 1 & 2.44705100 & 1.74356400 & -4.62755000 & 6 & -1.53018200 & 0.62676900 & -1.61755200 \\
\hline 6 & -1.71284900 & 3.58292900 & 2.08435700 & 6 & -2.58913900 & 1.12054600 & -0.66691400 \\
\hline 1 & -2.27085600 & 1.92450700 & 3.33811500 & 6 & -3.42952900 & -0.14260400 & -0.48531200 \\
\hline 1 & -0.96172700 & 5.03826500 & 0.66991900 & 8 & -3.29482000 & -0.83923800 & -1.73675300 \\
\hline 1 & 4.09734300 & 3.52267900 & -4.01729800 & 1 & -1.14797300 & -2.30339700 & -1.30211700 \\
\hline 1 & -2.43366300 & 4.26502300 & 2.54107500 & 1 & -1.84516900 & -0.93675500 & -3.19953600 \\
\hline 6 & -0.72880700 & -0.05372800 & 2.49248300 & 1 & -2.22570200 & 1.51892300 & 0.28892900 \\
\hline 1 & -0.14618600 & -0.76974300 & 1.89519000 & 1 & -0.85501500 & 1.31103800 & -2.13547600 \\
\hline 1 & -0.33183800 & -0.09770400 & 3.51864500 & 1 & -3.18073300 & 1.92241900 & -1.14642500 \\
\hline 1 & -1.75785900 & -0.44023200 & 2.54993400 & 1 & -2.92217100 & -0.78627900 & 0.26916400 \\
\hline 6 & 3.42575900 & 2.99896100 & 0.54893200 & 53 & 0.80462300 & -3.24052300 & 0.23307100 \\
\hline 1 & 4.18540000 & 2.31585000 & 0.96180400 & 15 & 1.29701500 & 0.61730800 & 0.03354400 \\
\hline 1 & 3.84164100 & 4.01357900 & 0.60394300 & 6 & 2.12805700 & 1.58166100 & -1.29542700 \\
\hline 1 & 2.56594500 & 2.94975300 & 1.22901900 & 6 & 0.35892300 & 1.82602000 & 1.04708600 \\
\hline 6 & 2.52529700 & 0.07937000 & 1.16356400 & 6 & 3.13692400 & 2.55110600 & -1.07669200 \\
\hline 6 & 3.60088200 & -0.69662600 & 0.67049800 & 6 & 1.78789700 & 1.23057800 & -2.61112900 \\
\hline 6 & 2.46798900 & 0.40639400 & 2.52463500 & 6 & -0.43586500 & 1.36574300 & 2.12836700 \\
\hline 6 & 4.56648100 & -1.13088200 & 1.58725800 & 6 & 0.28444300 & 3.17359300 & 0.66601800 \\
\hline 6 & 3.44237400 & -0.03705200 & 3.41290100 & 6 & 3.72404000 & 3.15249500 & -2.19983900 \\
\hline 1 & 1.66456200 & 1.04642600 & 2.89625000 & 6 & 2.39077100 & 1.83380800 & -3.70982700 \\
\hline 6 & 4.49474400 & -0.81649100 & 2.94043900 & 1 & 1.05401200 & 0.43164800 & -2.76557000 \\
\hline 1 & 5.39554900 & -1.74096300 & 1.21823600 & 6 & -1.21430000 & 2.30278100 & 2.82131700 \\
\hline 1 & 3.37833200 & 0.23026200 & 4.46993100 & 6 & -0.52194800 & 4.07835200 & 1.35231800 \\
\hline 1 & 5.26358300 & -1.18012900 & 3.62611000 & 1 & 0.86597400 & 3.52515300 & -0.19051600 \\
\hline 6 & 3.77369300 & -1.03407300 & -0.77622400 & 6 & 3.36200200 & 2.80907500 & -3.49908300 \\
\hline 1 & 2.82101400 & -1.27201300 & -1.27319300 & 1 & 4.49738600 & 3.90948800 & -2.04027900 \\
\hline 1 & 4.23241500 & -0.19923100 & -1.33183600 & 1 & 2.10881400 & 1.53679300 & -4.72220800 \\
\hline \multirow[t]{3}{*}{1} & 4.42648200 & -1.90786000 & -0.89725300 & 6 & -1.26408800 & 3.64328000 & 2.44661700 \\
\hline & & & & 1 & -1.81350600 & 1.95678000 & 3.66896300 \\
\hline & & & & 1 & -0.56070900 & 5.12243900 & 1.03413100 \\
\hline Pd-2-8 & & & & 1 & 3.84757700 & 3.29865200 & -4.34661600 \\
\hline 46 & -0.30777800 & -1.05552200 & -0.83929800 & 1 & -1.89041200 & 4.34308700 & 3.00461300 \\
\hline 6 & -7.52094900 & 0.49534700 & 0.66193900 & 6 & -0.54487500 & -0.08085100 & 2.49604000 \\
\hline 6 & -7.23436600 & -0.08973100 & -0.56940400 & 1 & -1.19286300 & -0.61797000 & 1.77962100 \\
\hline
\end{tabular}




\begin{tabular}{|c|c|c|c|c|c|c|c|}
\hline 1 & 0.40787600 & -0.62866600 & 2.48117000 & 1 & -3.58896000 & 0.82627400 & -2.41024800 \\
\hline 1 & -0.98977300 & -0.20932300 & 3.49133300 & 1 & -2.55157000 & -0.12529600 & 0.29712100 \\
\hline 6 & 3.64450000 & 2.93325400 & 0.27908200 & 53 & 1.35311800 & -3.19878700 & 0.13674100 \\
\hline 1 & 4.42901800 & 2.23732000 & 0.61770500 & 15 & 1.12110200 & 0.75240700 & 0.00947200 \\
\hline 1 & 4.09307800 & 3.93546800 & 0.26030100 & 6 & 1.80487700 & 2.06823700 & -1.08513500 \\
\hline 1 & 2.86987700 & 2.92539300 & 1.05594400 & 6 & 0.04809500 & 1.64600500 & 1.20866100 \\
\hline 6 & 2.70155800 & 0.04951100 & 1.06790000 & 6 & 2.76654700 & 3.03384200 & -0.69988500 \\
\hline 6 & 3.69285800 & -0.77633300 & 0.48795300 & 6 & 1.34569700 & 2.04311700 & -2.40986700 \\
\hline 6 & 2.79395800 & 0.39775700 & 2.42229900 & 6 & -0.71409400 & 0.93032900 & 2.17063100 \\
\hline 6 & 4.73420700 & -1.22825200 & 1.30968500 & 6 & -0.15577400 & 3.02862100 & 1.07355400 \\
\hline 6 & 3.83879200 & -0.06332300 & 3.21575900 & 6 & 3.23473500 & 3.92143000 & -1.67920500 \\
\hline 1 & 2.04691500 & 1.06327200 & 2.86397600 & 6 & 1.81969300 & 2.94052600 & -3.36287200 \\
\hline 6 & 4.81315800 & -0.88620400 & 2.65534100 & 1 & 0.60904200 & 1.27936200 & -2.68268500 \\
\hline 1 & 5.50049900 & -1.87303700 & 0.87000400 & 6 & -1.61546000 & 1.64534700 & 2.96993600 \\
\hline 1 & 3.89028000 & 0.22270000 & 4.26858600 & 6 & -1.06805500 & 3.71328800 & 1.87217200 \\
\hline 1 & 5.63676400 & -1.26221500 & 3.26683300 & 1 & 0.40580100 & 3.58554900 & 0.31916700 \\
\hline 6 & 3.70734000 & -1.13523500 & -0.96470700 & 6 & 2.77789600 & 3.88043000 & -2.99385600 \\
\hline 1 & 2.69720900 & -1.26293400 & -1.38059900 & 1 & 3.97773300 & 4.67118600 & -1.39151500 \\
\hline 1 & 4.20915300 & -0.35724100 & -1.56475000 & 1 & 1.44628800 & 2.89932700 & -4.38859900 \\
\hline \multirow[t]{3}{*}{1} & 4.24789000 & -2.07578700 & -1.13163800 & 6 & -1.79845200 & 3.01898300 & 2.83202600 \\
\hline & & & & 1 & -2.20064000 & 1.09489200 & 3.71261300 \\
\hline & & & & 1 & -1.20186000 & 4.78966700 & 1.74238500 \\
\hline Pd-2-9 & & & & 1 & 3.16892000 & 4.58951300 & -3.72770000 \\
\hline 46 & -0.17310200 & -0.91475700 & -1.02900000 & 1 & -2.51665800 & 3.54126700 & 3.46863200 \\
\hline 6 & -7.27554300 & 0.48196600 & 0.74134100 & 6 & -0.62134200 & -0.55277700 & 2.33400200 \\
\hline 6 & -6.99576800 & -0.66112500 & -0.00527100 & 1 & -0.90091700 & -1.07431600 & 1.39886700 \\
\hline 6 & -5.69276500 & -0.92960100 & -0.42352000 & 1 & 0.39509800 & -0.89945500 & 2.57566900 \\
\hline 6 & -4.65212800 & -0.05677000 & -0.09424300 & 1 & -1.29067500 & -0.91032800 & 3.12695300 \\
\hline 6 & -4.93838400 & 1.08652500 & 0.66290300 & 6 & 3.30834700 & 3.15178200 & 0.69115300 \\
\hline 6 & -6.24067000 & 1.35683700 & 1.07429000 & 1 & 4.11310300 & 2.42400200 & 0.88225500 \\
\hline 1 & -8.29739900 & 0.68978600 & 1.06780300 & 1 & 3.73229000 & 4.15045300 & 0.86065200 \\
\hline 1 & -7.80057200 & -1.35388400 & -0.26456900 & 1 & 2.54314900 & 2.97593500 & 1.45953100 \\
\hline 1 & -5.46634300 & -1.82568200 & -1.00447100 & 6 & 2.58736000 & 0.17180100 & 0.95562100 \\
\hline 1 & -4.12507700 & 1.76922000 & 0.93144700 & 6 & 3.62929800 & -0.48609000 & 0.25225600 \\
\hline 1 & -6.44971700 & 2.25347000 & 1.66322800 & 6 & 2.66247300 & 0.27112600 & 2.35311000 \\
\hline 6 & -2.02919100 & -1.60078300 & -1.94074300 & 6 & 4.68747000 & -1.03452600 & 0.99019900 \\
\hline 6 & -1.74104100 & -0.29275100 & -2.35847900 & 6 & 3.72188500 & -0.28512000 & 3.06333300 \\
\hline 6 & -2.76215500 & 0.60291300 & -1.70939600 & 1 & 1.88397800 & 0.81622400 & 2.89555300 \\
\hline 6 & -3.24643400 & -0.28784500 & -0.55542700 & 6 & 4.73907400 & -0.94740700 & 2.37859300 \\
\hline 8 & -3.06221300 & -1.63255100 & -1.01513500 & 1 & 5.48989900 & -1.54539400 & 0.44989300 \\
\hline 1 & 0.47408000 & -4.52039200 & -0.24040900 & 1 & 3.75445200 & -0.19492400 & 4.15160900 \\
\hline 1 & -1.92246000 & -2.53170900 & -2.50184300 & 1 & 5.57460100 & -1.39260700 & 2.92357000 \\
\hline 1 & -2.37550500 & 1.56526000 & -1.34011500 & 6 & 3.64915500 & -0.57696300 & -1.24208000 \\
\hline 1 & -1.32129300 & -0.06984700 & -3.34356000 & 1 & 2.65348900 & -0.81099400 & -1.65903300 \\
\hline
\end{tabular}




\begin{tabular}{|c|c|c|c|c|c|c|c|}
\hline 1 & 3.95015600 & 0.37859000 & -1.70176100 & 6 & -2.63271100 & 0.91468500 & 0.42544800 \\
\hline \multirow[t]{3}{*}{1} & 4.35412200 & -1.34436900 & -1.58757700 & 6 & -2.93168400 & 1.86364400 & -0.58606800 \\
\hline & & & & 6 & -3.06459500 & 1.15397700 & 1.73790500 \\
\hline & & & & 6 & -3.64114500 & 3.01790900 & -0.22522000 \\
\hline \multicolumn{2}{|c|}{ Pd-2-10 } & & & 6 & -3.76616700 & 2.30920600 & 2.07082900 \\
\hline 46 & 0.61445300 & 0.08385500 & -0.58267900 & 1 & -2.86324000 & 0.40877700 & 2.51355000 \\
\hline 6 & 2.68522700 & -0.20242300 & -1.05364300 & 6 & -4.05399000 & 3.24941200 & 1.08406800 \\
\hline 6 & 2.03282500 & -1.45243100 & -0.98169000 & 1 & -3.87103000 & 3.75282300 & -1.00261500 \\
\hline 6 & 2.47259900 & -2.11628700 & 0.29409200 & 1 & -4.09058700 & 2.47016900 & 3.10159000 \\
\hline 1 & 1.89521500 & 3.40214900 & -0.16914800 & 1 & -4.60159700 & 4.16176900 & 1.33133900 \\
\hline 1 & 2.97291300 & 0.28506600 & -1.99067200 & 6 & -2.54573100 & 1.65995200 & -2.01927000 \\
\hline 1 & 1.66608800 & -2.57638700 & 0.88876300 & 1 & -1.53096900 & 1.23773300 & -2.12449700 \\
\hline 1 & 1.75219500 & -2.05385000 & -1.85246800 & 1 & -3.22136700 & 0.95189400 & -2.52674700 \\
\hline 1 & 3.21371700 & -2.91877600 & 0.08231100 & 1 & -2.58091300 & 2.60424200 & -2.57851000 \\
\hline 53 & 0.32504700 & 2.98556300 & -0.04471100 & 8 & 3.05390100 & -1.08008000 & 1.06640000 \\
\hline 15 & -1.56936000 & -0.52910200 & 0.00486300 & 6 & 3.55892300 & -0.07365100 & 0.17484600 \\
\hline 6 & -2.54588600 & -1.42556100 & -1.27435000 & 1 & 3.43925800 & 0.88650500 & 0.70957100 \\
\hline 6 & -1.60395200 & -1.62416500 & 1.48318900 & 6 & 5.03668600 & -0.28261600 & -0.08880000 \\
\hline 6 & -3.94870700 & -1.61723900 & -1.25179200 & 6 & 5.98832200 & 0.41421700 & 0.66326300 \\
\hline 6 & -1.80391200 & -1.89236600 & -2.36886100 & 6 & 5.48582600 & -1.20135000 & -1.04624900 \\
\hline 6 & -0.82168400 & -1.29730800 & 2.62074100 & 6 & 7.35197700 & 0.20135700 & 0.47024300 \\
\hline 6 & -2.28446500 & -2.85061300 & 1.45241000 & 1 & 5.64829200 & 1.13397700 & 1.41455100 \\
\hline 6 & -4.53984200 & -2.26856200 & -2.34417900 & 6 & 6.84786400 & -1.42301000 & -1.23785600 \\
\hline 6 & -2.41227600 & -2.54079600 & -3.43941800 & 1 & 4.75508400 & -1.74178400 & -1.65556600 \\
\hline 1 & -0.72259800 & -1.71512400 & -2.36987500 & 6 & 7.78592200 & -0.72102600 & -0.48097200 \\
\hline 6 & -0.79758900 & -2.19994200 & 3.69147900 & 1 & 8.08041300 & 0.75860500 & 1.06470200 \\
\hline 6 & -2.23333300 & -3.73722400 & 2.52494900 & 1 & 7.18141200 & -2.14400000 & -1.98856800 \\
\hline 1 & -2.86235900 & -3.12692400 & 0.56724900 & 1 & 8.85443400 & -0.88953100 & -0.63566600 \\
\hline 6 & -3.79229000 & -2.72384000 & -3.42701700 & & & & \\
\hline 1 & -5.62298800 & -2.42262800 & -2.33604600 & & & & \\
\hline 1 & -1.81096200 & -2.89388100 & -4.28018100 & $\mathrm{Pd}-2$ & & & \\
\hline 6 & -1.49135600 & -3.40632600 & 3.65520800 & 46 & -1.01287900 & 0.54167400 & -0.15570500 \\
\hline 1 & -0.20029800 & -1.94599000 & 4.57184400 & 6 & -5.00433900 & 0.78003100 & -2.33315200 \\
\hline 1 & -2.77596800 & -4.68401300 & 2.47345400 & 6 & -5.16604900 & 0.82610400 & -0.94269700 \\
\hline 1 & -4.29172500 & -3.22543200 & -4.25957800 & 6 & -4.21707700 & 0.26502800 & -0.09775200 \\
\hline 1 & -1.44408500 & -4.08974700 & 4.50638400 & 6 & -3.06340300 & -0.32365600 & -0.64449200 \\
\hline 6 & 0.01493600 & -0.06038200 & 2.69391200 & 6 & -2.92950500 & -0.43747700 & -2.03946400 \\
\hline 1 & 0.88996800 & -0.14170600 & 2.02129900 & 6 & -3.88833600 & 0.14385000 & -2.87304100 \\
\hline 1 & -0.52875900 & 0.84698100 & 2.39113900 & 1 & -5.75870700 & 1.21878500 & -2.98977900 \\
\hline 1 & 0.39719800 & 0.10315400 & 3.70993000 & 1 & -6.04340400 & 1.31346400 & -0.50870800 \\
\hline 6 & -4.83047800 & -1.14989100 & -0.13443200 & 1 & -4.33700300 & 0.32839400 & 0.98590800 \\
\hline 1 & -5.08881800 & -0.08324000 & -0.23455200 & 1 & -2.08042100 & -0.97273900 & -2.47231800 \\
\hline 1 & -5.77557500 & -1.70883800 & -0.12323400 & 1 & -3.76284800 & 0.07895500 & -3.95716900 \\
\hline 1 & -4.36142400 & -1.26109400 & 0.85241500 & 6 & -1.61549500 & 2.71431600 & 2.22066700 \\
\hline
\end{tabular}




\begin{tabular}{|c|c|c|c|c|c|c|c|}
\hline 6 & -0.42420800 & 3.22021700 & 1.41559200 & 1 & 0.99506500 & 0.84946600 & 2.56531100 \\
\hline 6 & -0.82856700 & 2.79967300 & 0.02406400 & 6 & 1.56919000 & -2.93361500 & 2.92523700 \\
\hline 6 & -2.19200100 & 2.59648100 & 0.06575000 & 6 & 1.29761200 & -2.17530800 & 4.05746700 \\
\hline 8 & -2.72756800 & 2.71679800 & 1.31403100 & 1 & 0.84871400 & -0.18743200 & 4.79217000 \\
\hline 1 & -1.88730000 & 3.31846000 & 3.09565200 & 1 & 1.69463900 & -4.01590900 & 3.02238800 \\
\hline 1 & -1.44866600 & 1.66725900 & 2.54677600 & 1 & 1.22081300 & -2.65714200 & 5.03479900 \\
\hline 1 & 0.53496700 & 2.80767300 & 1.76535300 & 6 & 1.90282400 & -3.30283800 & 0.49180900 \\
\hline 1 & -0.32897800 & 4.32093700 & 1.46748700 & 1 & 1.16226200 & -3.17006400 & -0.30923200 \\
\hline 1 & -0.29326200 & 3.11923800 & -0.87099000 & 1 & 2.88981100 & -3.17101000 & 0.02535000 \\
\hline 1 & -2.91737400 & 2.59019600 & -0.74790100 & 1 & 1.84130200 & -4.34571100 & 0.82792100 \\
\hline 53 & -2.03522600 & -1.91718100 & 0.66259400 & & & & \\
\hline 15 & 1.33154900 & -0.02932900 & -0.04901300 & & & & \\
\hline 6 & 2.09908100 & -0.95016600 & -1.44375500 & \multicolumn{2}{|c|}{ Pd-2-TS2 } & & \\
\hline 6 & 2.43155100 & 1.44056300 & 0.08014700 & 46 & -1.02004600 & 0.50931400 & -0.17595800 \\
\hline 6 & 3.48341200 & -1.20627800 & -1.56865700 & 6 & -5.62696900 & -0.24678300 & -1.28573000 \\
\hline 6 & 1.22708000 & -1.34653900 & -2.46617300 & 6 & -5.34336800 & 0.03388600 & 0.05148000 \\
\hline 6 & 3.19409300 & 1.73658300 & 1.22021200 & 6 & -4.09624800 & 0.53906700 & 0.41406500 \\
\hline 6 & 2.43946400 & 2.35192300 & -1.00721200 & 6 & -3.11914200 & 0.75337300 & -0.55950800 \\
\hline 6 & 3.92983500 & -1.85342300 & -2.72887500 & 6 & -3.41808300 & 0.50999200 & -1.90594400 \\
\hline 6 & 1.68981900 & -1.99329200 & -3.60752200 & 6 & -4.66225700 & -0.00674400 & -2.26508900 \\
\hline 1 & 0.15945400 & -1.12824100 & -2.34674100 & 1 & -6.60525300 & -0.64380300 & -1.56689800 \\
\hline 6 & 3.92426800 & 2.91716600 & 1.32067400 & 1 & -6.09691500 & -0.14940700 & 0.82166500 \\
\hline 1 & 3.23770600 & 1.01958900 & 2.04343100 & 1 & -3.87891500 & 0.75572900 & 1.46317300 \\
\hline 6 & 3.17619700 & 3.53706000 & -0.87745000 & 1 & -2.67313100 & 0.71465300 & -2.68367800 \\
\hline 6 & 3.05399100 & -2.24300900 & -3.73883400 & 1 & -4.88095800 & -0.21547400 & -3.31564500 \\
\hline 1 & 4.99851300 & -2.06424800 & -2.83226300 & 6 & -1.57376000 & 2.95059600 & 1.90879900 \\
\hline 1 & 0.99036100 & -2.29815900 & -4.38902500 & 6 & -0.35353800 & 3.21987600 & 1.04982900 \\
\hline 6 & 3.90562400 & 3.83144200 & 0.27018400 & 6 & -0.79212800 & 2.61898200 & -0.26939400 \\
\hline 1 & 4.51123700 & 3.11713400 & 2.22027000 & 6 & -2.22213500 & 2.64643300 & -0.21840400 \\
\hline 1 & 3.17498300 & 4.24406900 & -1.71244100 & 8 & -2.67952400 & 3.02307900 & 0.99246100 \\
\hline 1 & 3.44016800 & -2.74725200 & -4.62808700 & 1 & -1.76347100 & 3.66985800 & 2.71425500 \\
\hline 1 & 4.46704800 & 4.76625600 & 0.33792000 & 1 & -1.54558600 & 1.92937900 & 2.33880100 \\
\hline 6 & 1.73713100 & 2.07855800 & -2.30109900 & 1 & 0.57339700 & 2.80789300 & 1.47335400 \\
\hline 1 & 1.56973600 & 3.00581800 & -2.86560000 & 1 & -0.18413800 & 4.30588100 & 0.92942100 \\
\hline 1 & 2.32848100 & 1.40963900 & -2.94756200 & 1 & -0.29818200 & 2.92326700 & -1.19697000 \\
\hline 1 & 0.76356800 & 1.58095500 & -2.15699700 & 1 & -2.85736900 & 2.96703500 & -1.04260700 \\
\hline 6 & 4.47736100 & -0.84002100 & -0.51181000 & 53 & -1.61863600 & -2.13040800 & 0.47918500 \\
\hline 1 & 4.82350600 & 0.20054500 & -0.61937900 & 15 & 1.29644700 & -0.00388400 & 0.00549200 \\
\hline 1 & 4.05967100 & -0.92097500 & 0.50229800 & 6 & 2.21131800 & -0.92329300 & -1.30514100 \\
\hline 1 & 5.36671800 & -1.48212900 & -0.56727700 & 6 & 2.38512500 & 1.49357300 & 0.06054300 \\
\hline 6 & 1.51433900 & -0.96907100 & 1.51668900 & 6 & 3.60243700 & -0.99588200 & -1.12367100 \\
\hline 6 & 1.19018100 & -0.22286700 & 2.66649200 & 6 & 1.63091200 & -1.46085500 & -2.47446800 \\
\hline 6 & 1.67095500 & -2.37088900 & 1.64174000 & 6 & 3.13307000 & 1.84727500 & 1.19267900 \\
\hline 6 & 1.09597300 & -0.80332700 & 3.92465000 & 6 & 2.43175900 & 2.33260100 & -1.08119100 \\
\hline
\end{tabular}




\begin{tabular}{|c|c|c|c|c|c|c|c|}
\hline 6 & 4.42640900 & -1.62033000 & -2.05095200 & 6 & 5.07783200 & -0.91250300 & 0.17145600 \\
\hline 1 & 4.04842200 & -0.55829600 & -0.22498100 & 6 & 5.51396100 & -1.42231600 & -1.04827100 \\
\hline 6 & 2.48653400 & -2.08629600 & -3.39716600 & 1 & 5.43258600 & -1.23312500 & -3.19868300 \\
\hline 6 & 3.86925700 & 3.02929300 & 1.23838500 & 1 & 3.90635300 & 0.73364200 & -3.13231600 \\
\hline 1 & 3.15119600 & 1.18476500 & 2.05967900 & 1 & 3.12431900 & 1.63153400 & -0.94964600 \\
\hline 6 & 3.16165500 & 3.52565100 & -1.00276400 & 1 & 5.41042700 & -1.37600000 & 1.10594000 \\
\hline 6 & 3.85873500 & -2.17590400 & -3.19636800 & 1 & 6.18537100 & -2.28390700 & -1.06829500 \\
\hline 1 & 5.50433300 & -1.66816500 & -1.88164000 & 6 & 2.40101100 & 2.23304100 & 2.55937200 \\
\hline 1 & 2.04763300 & -2.50691800 & -4.30631400 & 6 & 1.72494100 & 0.90347100 & 2.79565500 \\
\hline 6 & 3.86695600 & 3.88547100 & 0.14193700 & 6 & 2.54476100 & -0.07363800 & 2.19331300 \\
\hline 1 & 4.44270400 & 3.27579600 & 2.13493400 & 6 & 3.70564600 & 0.66546700 & 1.54317200 \\
\hline 1 & 3.18336200 & 4.18139600 & -1.87828300 & 8 & 3.24540500 & 2.00918100 & 1.45747200 \\
\hline 1 & 4.48743700 & -2.66910200 & -3.94159800 & 1 & 2.98618600 & 2.49552000 & 3.46766300 \\
\hline 1 & 4.42717300 & 4.82305900 & 0.16785900 & 1 & 1.73927000 & 3.08083200 & 2.33283900 \\
\hline 6 & 1.79419200 & 1.97217900 & -2.38751800 & 1 & 0.22009400 & 1.25814000 & 1.90032300 \\
\hline 1 & 1.57973200 & 2.86755300 & -2.98701200 & 1 & 1.15299200 & 0.72310300 & 3.70986900 \\
\hline 1 & 2.46257300 & 1.33497700 & -2.98945900 & 1 & 2.65688500 & -1.09823900 & 2.55386900 \\
\hline 1 & 0.85541500 & 1.41082900 & -2.26899700 & 1 & 4.55207300 & 0.61438000 & 2.26911500 \\
\hline 6 & 0.17230900 & -1.40097000 & -2.78719400 & 53 & 1.38418500 & -2.26532200 & -0.28303500 \\
\hline 1 & -0.27096600 & -0.41890900 & -2.55673500 & 15 & -1.18326900 & 0.58896200 & -0.24831600 \\
\hline 1 & -0.01220700 & -1.61908400 & -3.84702400 & 6 & -2.63645600 & 0.86002100 & 0.84094900 \\
\hline 1 & -0.40650900 & -2.12079900 & -2.18593400 & 6 & -0.85134400 & 2.18474900 & -1.10771200 \\
\hline 6 & 1.56595800 & -0.85109100 & 1.61390800 & 6 & -1.70103100 & -0.53286700 & -1.65882500 \\
\hline 6 & 1.91520800 & -2.20585900 & 1.81895100 & 6 & -3.30928000 & 2.09032100 & 0.86500600 \\
\hline 6 & 1.19717300 & -0.06473500 & 2.71998200 & 6 & -3.02498400 & -0.16239400 & 1.74346300 \\
\hline 6 & 1.95754300 & -2.66931800 & 3.14433900 & 6 & -1.72733400 & 2.81769300 & -2.02489100 \\
\hline 6 & 1.23592100 & -0.55216500 & 4.01904200 & 6 & 0.40394600 & 2.76724700 & -0.85742500 \\
\hline 1 & 0.85578900 & 0.96150100 & 2.54891800 & 1 & -2.02161800 & 0.13138000 & -2.47248700 \\
\hline 6 & 1.63535700 & -1.86891300 & 4.23242700 & 1 & -0.75682600 & -0.99771600 & -1.98346600 \\
\hline 1 & 2.22445900 & -3.71646400 & 3.31179700 & 6 & -2.73693600 & -1.58724600 & -1.40874700 \\
\hline 1 & 0.94122900 & 0.08734400 & 4.85375300 & 6 & -4.39298700 & 2.30699900 & 1.71179900 \\
\hline 1 & 1.66927500 & -2.28151000 & 5.24336500 & 1 & -2.97756600 & 2.90422000 & 0.21638500 \\
\hline 6 & 2.17238400 & -3.20212300 & 0.73068900 & 6 & -4.13186700 & 0.07450400 & 2.56856000 \\
\hline 1 & 1.43687600 & -3.11541400 & -0.08027800 & 6 & -1.29695500 & 4.00155100 & -2.64171000 \\
\hline 1 & 3.16965900 & -3.10166700 & 0.27812500 & 6 & 0.80966100 & 3.93933700 & -1.48603600 \\
\hline \multirow[t]{3}{*}{1} & 2.09670700 & -4.22100100 & 1.13087200 & 1 & 1.08810100 & 2.27708200 & -0.15642600 \\
\hline & & & & 6 & -2.38009800 & -2.94311400 & -1.42336800 \\
\hline & & & & 6 & -4.07662300 & -1.25367800 & -1.16076000 \\
\hline \multicolumn{2}{|c|}{ Pd-2-TS3 } & & & 6 & -4.81941500 & 1.28441800 & 2.55410900 \\
\hline 46 & 0.72666800 & 0.03849300 & 1.02279200 & 1 & -4.90150400 & 3.27373500 & 1.70752200 \\
\hline 6 & 5.09185900 & -0.83476400 & -2.24009100 & 1 & -4.44968800 & -0.71911700 & 3.25068900 \\
\hline 6 & 4.23663600 & 0.26480400 & -2.20208000 & 6 & -0.04885000 & 4.56005200 & -2.38864700 \\
\hline 6 & 3.79330500 & 0.76932700 & -0.98126000 & 1 & -1.97503600 & 4.49559800 & -3.34388900 \\
\hline 6 & 4.20620500 & 0.17855700 & 0.21482300 & 1 & 1.79618000 & 4.35608600 & -1.26964800 \\
\hline
\end{tabular}




\begin{tabular}{|c|c|c|c|c|c|c|c|}
\hline 6 & -3.32950400 & -3.93301900 & -1.18004800 & 53 & -0.60432700 & -3.32483000 & 0.17352900 \\
\hline 1 & -1.33523600 & -3.21230500 & -1.60342100 & 15 & -1.35515200 & 0.57591000 & -0.09384700 \\
\hline 6 & -5.02570500 & -2.24278200 & -0.91211700 & 6 & -1.38793100 & 1.66071500 & 1.38581700 \\
\hline 1 & -4.38446700 & -0.20402500 & -1.14557600 & 6 & -1.19855700 & 1.67686100 & -1.55497700 \\
\hline 1 & -5.67685500 & 1.43291300 & 3.21468900 & 6 & -0.33293100 & 1.49447900 & 2.29627400 \\
\hline 1 & 0.24881600 & 5.48079800 & -2.89599100 & 6 & -2.43956700 & 2.55984000 & 1.68808800 \\
\hline 6 & -4.65433600 & -3.58673000 & -0.91549800 & 6 & -1.05168900 & 1.10112300 & -2.84251000 \\
\hline 1 & -3.02895400 & -4.98337000 & -1.19113600 & 6 & -1.05894100 & 3.06341600 & -1.40000900 \\
\hline 1 & -6.06237400 & -1.95986800 & -0.71327800 & 6 & -0.28359900 & 2.21184000 & 3.48741100 \\
\hline 1 & -5.39791100 & -4.36269400 & -0.71848700 & 1 & 0.46156200 & 0.77421500 & 2.06709500 \\
\hline 6 & -3.09368100 & 2.31426200 & -2.38577600 & 6 & -2.36455000 & 3.27114700 & 2.89371200 \\
\hline 1 & -3.09955300 & 1.83830900 & -3.37972000 & 6 & -0.82279300 & 1.95858500 & -3.92632600 \\
\hline 1 & -3.49449100 & 1.58580500 & -1.67359600 & 6 & -0.80873200 & 3.89126600 & -2.49220200 \\
\hline 1 & -3.81113000 & 3.14521700 & -2.44113300 & 1 & -1.13945700 & 3.50726600 & -0.40379400 \\
\hline 6 & -2.26873700 & -1.44333900 & 1.89359000 & 6 & -1.30827200 & 3.10653600 & 3.78526300 \\
\hline 1 & -2.03859100 & -1.94185300 & 0.94247700 & 1 & 0.55061100 & 2.06533800 & 4.17660000 \\
\hline 1 & -1.29135700 & -1.26675000 & 2.37677200 & 1 & -3.16881100 & 3.97202200 & 3.13588100 \\
\hline 1 & -2.82109100 & -2.16039100 & 2.51440200 & 6 & -0.70049100 & 3.33611700 & -3.76409400 \\
\hline & & & & 1 & -0.72480500 & 1.52220100 & -4.92458100 \\
\hline & & & & 1 & -0.70572500 & 4.96870500 & -2.34543300 \\
\hline Pd-2. & & & & 1 & -1.28925800 & 3.67827300 & 4.71625900 \\
\hline 46 & 0.56980000 & -0.91108000 & -0.16242700 & 1 & -0.51344000 & 3.97354900 & -4.63133700 \\
\hline 6 & 7.66517200 & 0.33908600 & -0.16177000 & 6 & -3.64030200 & 2.76158600 & 0.81637900 \\
\hline 6 & 6.95290000 & 1.33845500 & 0.49814000 & 1 & -4.41493900 & 2.00508000 & 1.02223200 \\
\hline 6 & 5.59901300 & 1.16632400 & 0.78503000 & 1 & -4.09572700 & 3.74405100 & 0.99937600 \\
\hline 6 & 4.93985400 & -0.00655700 & 0.40804000 & 1 & -3.41777900 & 2.68782600 & -0.25572000 \\
\hline 6 & 5.66442100 & -1.01012400 & -0.24767200 & 6 & -1.06007800 & -0.37749100 & -3.07907200 \\
\hline 6 & 7.01692800 & -0.84004400 & -0.53033400 & 1 & -1.78963900 & -0.92864600 & -2.46999500 \\
\hline 1 & 8.72603400 & 0.47474100 & -0.38461200 & 1 & -1.26120100 & -0.61047300 & -4.13288000 \\
\hline 1 & 7.45668600 & 2.26091500 & 0.79741200 & 1 & -0.07804500 & -0.82005100 & -2.83449400 \\
\hline 1 & 5.03971200 & 1.93738600 & 1.31900800 & 6 & -3.04909200 & -0.12649800 & -0.15297500 \\
\hline 1 & 5.16641700 & -1.94274400 & -0.53169400 & 6 & -3.53178100 & -0.87275800 & 0.94756500 \\
\hline 1 & 7.56863300 & -1.63291000 & -1.04099400 & 6 & -3.86708400 & 0.06154800 & -1.27640700 \\
\hline 6 & 2.27810700 & 1.68697500 & 0.22818000 & 6 & -4.82076700 & -1.41713300 & 0.85523800 \\
\hline 6 & 1.90901500 & 0.66789100 & -0.80779500 & 6 & -5.14456200 & -0.48365700 & -1.33862400 \\
\hline 6 & 2.67370000 & -0.49141000 & -0.54595000 & 1 & -3.51167700 & 0.67050900 & -2.11242900 \\
\hline 6 & 3.47165300 & -0.21668700 & 0.72328400 & 6 & -5.62143400 & -1.23452100 & -0.26661400 \\
\hline 8 & 2.85446000 & 0.93544100 & 1.28217100 & 1 & -5.19795300 & -2.00219000 & 1.69879100 \\
\hline 1 & 1.44793900 & 2.28376600 & 0.63624700 & 1 & -5.76438100 & -0.31853400 & -2.22262200 \\
\hline 1 & 3.00952600 & 2.40555300 & -0.20288900 & 1 & -6.62009100 & -1.67617400 & -0.30223700 \\
\hline 1 & 1.70036700 & -2.00986200 & -0.17951800 & 6 & -2.76605700 & -1.04117800 & 2.22186700 \\
\hline 1 & 1.61876000 & 0.98144200 & -1.81651400 & 1 & -1.68101600 & -1.11267200 & 2.06424600 \\
\hline 1 & 3.11108600 & -1.10218500 & -1.33920400 & 1 & -2.93988300 & -0.19272600 & 2.90540600 \\
\hline 1 & 3.37336400 & -1.02141100 & 1.47159900 & 1 & -3.07602700 & -1.95316500 & 2.74801100 \\
\hline
\end{tabular}


Pd-2-TS5

\begin{tabular}{|c|c|c|c|}
\hline 46 & -0.16225200 & -1.09179900 & -0.95457100 \\
\hline 6 & -7.29084700 & 0.54807600 & 0.77016700 \\
\hline 6 & -7.03509900 & 0.15443300 & -0.54313300 \\
\hline & -5.73137200 & -0.11244800 & -0.95472500 \\
\hline & -4.66775000 & 0.00414500 & -0.05382100 \\
\hline 0 & -4.93226100 & 0.39214500 & 1.26334500 \\
\hline & -6.23522300 & 0.66772500 & 1.67290600 \\
\hline 1 & -8.31423900 & 0.75480500 & 1.09185400 \\
\hline 1 & -7.85908200 & 0.04998500 & -1.25302200 \\
\hline 1 & -5.52907600 & -0.43022900 & -1.98018800 \\
\hline 1 & -4.10395200 & 0.47346200 & 1.97373300 \\
\hline 1 & -6.42856000 & 0.96610000 & 2.70603400 \\
\hline 6 & -2.06515600 & -1.02371200 & -2.22160300 \\
\hline 6 & -1.51351300 & 0.25763000 & -1.98454900 \\
\hline 6 & -2.52845900 & 0.96040100 & -1.11696000 \\
\hline 6 & -3.25683000 & -0.22786900 & -0.49129600 \\
\hline 8 & -3.20133500 & -1.24200800 & -1.51892300 \\
\hline 1 & -0.95200000 & -2.34105800 & -1.52583800 \\
\hline 1 & -1.98992500 & -1.60936400 & -3.13838300 \\
\hline 1 & -2.12929000 & 1.64541300 & -0.35811500 \\
\hline 1 & -0.97144300 & 0.79478500 & -2.76701000 \\
\hline 1 & -3.22080900 & 1.54686400 & -1.74980100 \\
\hline 1 & -2.64362400 & -0.60265700 & 0.35731900 \\
\hline 53 & 0.98159500 & -3.26215500 & 0.18411300 \\
\hline 15 & 1.22032300 & 0.65721000 & 0.03214000 \\
\hline 6 & 2.07343900 & 1.71557000 & -1.20746600 \\
\hline 6 & 0.10757500 & 1.76355100 & 0.98532700 \\
\hline 6 & 2.98316400 & 2.75201100 & -0.88452900 \\
\hline 6 & 1.85979600 & 1.38317500 & -2.55338800 \\
\hline 6 & -0.73421100 & 1.23826300 & 2.00095900 \\
\hline 6 & -0.06098100 & 3.09605800 & 0.57662200 \\
\hline 6 & 3.60993100 & 3.42774000 & -1.94141600 \\
\hline 6 & 2.49990500 & 2.06288400 & -3.58499900 \\
\hline 1 & 1.19738600 & 0.54253800 & -2.78446300 \\
\hline 6 & -1.68465200 & 2.09553800 & 2.57502200 \\
\hline 6 & -1.02197200 & 3.91949900 & 1.15563000 \\
\hline 1 & 0.56156800 & 3.49776600 & -0.22692100 \\
\hline 6 & 3.37718600 & 3.09770400 & -3.27344000 \\
\hline 1 & 4.30625000 & 4.23654600 & -1.70168800 \\
\hline 1 & 2.31877000 & 1.77950900 & -4.62405000 \\
\hline 6 & -1.83808200 & 3.41658600 & 2.16515100 \\
\hline
\end{tabular}

$1-2.33052000$

$1-1.13258800$

$1 \quad 3.88897000$

$1 \quad-2.59927800$

$6 \quad-0.66044400$

$1 \quad-0.43626400$

$1 \quad 0.12869900$

$1-1.60455500$

$6 \quad 3.33836300$

14.14365000

$1 \quad 3.70113400$

$1 \quad 2.49936800$

$6 \quad 2.57914700$

$6 \quad 3.66081600$

$6 \quad 2.56090000$

$6 \quad 4.67064000$

$6 \quad 3.57795200$

1.75215100

$6 \quad 4.63568100$

$1 \quad 5.50576400$

$1 \quad 3.54422500$

$1 \quad 5.43856900$

$6 \quad 3.80068300$

$1 \quad 2.83689300$

$1 \quad 4.24384400$

$1 \quad 4.45288100$

\begin{tabular}{|c|c|}
\hline 1.69873700 & 3.36424000 \\
\hline 4.95055300 & 0.81258000 \\
\hline 3.64682200 & -4.06735600 \\
\hline 4.04788100 & 2.62911500 \\
\hline-0.17824300 & 2.47790500 \\
\hline-0.89657200 & 1.67178100 \\
\hline-0.32764800 & 3.23132200 \\
\hline-0.48899300 & 2.94541600 \\
\hline 3.13812600 & 0.51746400 \\
\hline 2.49836500 & 0.91301000 \\
\hline 4.17371100 & 0.55876900 \\
\hline 3.04474500 & 1.21834500 \\
\hline 0.16847500 & 1.16024000 \\
\hline-0.58644100 & 0.64883700 \\
\hline 0.52673200 & 2.51455600 \\
\hline-0.97267100 & 1.54007200 \\
\hline 0.13253700 & 3.37802100 \\
\hline 1.15548100 & 2.89688600 \\
\hline-0.62915600 & 2.88743700 \\
\hline-1.56437600 & 1.15472900 \\
\hline 0.42521000 & 4.42981700 \\
\hline-0.95307800 & 3.55385000 \\
\hline-0.93057700 & -0.80027400 \\
\hline-1.16962800 & -1.27438900 \\
\hline-0.09519500 & -1.36855100 \\
\hline-1.80296000 & -0.93582700 \\
\hline 0.70648100 & -1.05887900 \\
\hline-0.65460800 & 0.76227100 \\
\hline 0.46450900 & -0.02375300 \\
\hline 0.73022900 & -0.45168200 \\
\hline-0.12021500 & -0.09148900 \\
\hline-1.23799600 & 0.70650800 \\
\hline-1.50672400 & 1.12652700 \\
\hline-0.86090100 & 1.09544400 \\
\hline 1.13979200 & -0.30743800 \\
\hline 1.60718200 & -1.06462900 \\
\hline-1.90263600 & 1.00071700 \\
\hline-2.38360100 & 1.74715200 \\
\hline 1.39972100 & -1.97200200 \\
\hline 0.09050500 & -2.38350500 \\
\hline-0.79447400 & -1.72065900 \\
\hline
\end{tabular}

Pd-2-TS6

$\begin{array}{cc}46 & 0.24197700 \\ 6 & 7.32923300 \\ 6 & 7.06034500 \\ 6 & 5.76010400 \\ 6 & 4.71105800 \\ 6 & 4.98628100 \\ 6 & 6.28614100 \\ 1 & 8.34917400 \\ 1 & 7.87164800 \\ 1 & 5.54304000 \\ 1 & 4.16690200 \\ 1 & 6.48664200 \\ 6 & 2.09883600 \\ 6 & 1.81785200 \\ 6 & 2.83901200\end{array}$

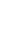




\begin{tabular}{|c|c|c|c|c|c|c|c|}
\hline 6 & 3.30944500 & 0.10429200 & -0.56751000 & 6 & -4.69560800 & 1.40728200 & 2.23908500 \\
\hline 8 & 3.12617800 & 1.44641700 & -1.04137100 & 1 & -5.29994500 & 2.06568400 & 0.27813300 \\
\hline 1 & 0.57215100 & 3.44322600 & -0.36916700 & 1 & -3.87210100 & 0.56730200 & 4.05476300 \\
\hline 1 & 1.98203400 & 2.32702900 & -2.53832600 & 1 & -5.49018900 & 1.95715200 & 2.74891400 \\
\hline 1 & 2.45869100 & -1.75889300 & -1.35199500 & 6 & -3.52781700 & 0.85570800 & -1.33456700 \\
\hline 1 & 1.39541700 & -0.14416300 & -3.36431400 & 1 & -2.49651200 & 0.99494900 & -1.70648900 \\
\hline 1 & 3.67190700 & -1.01335800 & -2.41581900 & 1 & -3.89411000 & -0.07362300 & -1.80066700 \\
\hline 1 & 2.60303700 & -0.05022500 & 0.27720700 & 1 & -4.14492200 & 1.67928200 & -1.71727600 \\
\hline 53 & -0.97920000 & 3.39562500 & 0.13093800 & & & & \\
\hline 15 & -1.24011400 & -0.75876700 & 0.02114800 & & & & \\
\hline 6 & -2.02340100 & -2.03182500 & -1.05545800 & \multicolumn{2}{|c|}{ Pd-2-TS7 } & & \\
\hline 6 & -0.29214500 & -1.70875900 & 1.27912800 & 46 & 0.58043400 & 0.05949000 & -0.60335200 \\
\hline 6 & -3.08372300 & -2.88773600 & -0.67046300 & 6 & 2.67124400 & -0.22299000 & -1.06424600 \\
\hline 6 & -1.52270800 & -2.10127400 & -2.36386400 & 6 & 2.00548600 & -1.46446300 & -0.98412800 \\
\hline 6 & 0.52069400 & -1.02455900 & 2.22172600 & 6 & 2.42902700 & -2.12304100 & 0.29943800 \\
\hline 6 & -0.22006800 & -3.10887200 & 1.20931700 & 1 & 1.83481900 & 2.47082700 & -0.60297700 \\
\hline 6 & -3.59784300 & -3.77081300 & -1.63078900 & 1 & 2.97127700 & 0.24526600 & -2.00764100 \\
\hline 6 & -2.04488900 & -2.99155200 & -3.29790500 & 1 & 1.61087400 & -2.55952600 & 0.89649900 \\
\hline 1 & -0.70875800 & -1.42099300 & -2.63964900 & 1 & 1.71591400 & -2.06778600 & -1.85063200 \\
\hline 6 & 1.34173800 & -1.78251700 & 3.06638600 & 1 & 3.15326900 & -2.94278300 & 0.09656500 \\
\hline 6 & 0.61423400 & -3.83822900 & 2.05345900 & 53 & 0.43296900 & 3.09529200 & -0.04046500 \\
\hline 1 & -0.82079500 & -3.64484900 & 0.46996600 & 15 & -1.60171600 & -0.52558100 & 0.00105100 \\
\hline 6 & -3.09482100 & -3.82727000 & -2.92769500 & 6 & -2.59938500 & -1.38353700 & -1.28685400 \\
\hline 1 & -4.41674400 & -4.43659400 & -1.34232800 & 6 & -1.58857900 & -1.66740500 & 1.44275800 \\
\hline 1 & -1.63591700 & -3.02676100 & -4.31022800 & 6 & -3.99919300 & -1.59054700 & -1.23370900 \\
\hline 6 & 1.39672800 & -3.17202200 & 2.99159000 & 6 & -1.88323200 & -1.79919700 & -2.41868200 \\
\hline 1 & 1.96654400 & -1.25569000 & 3.79376900 & 6 & -0.78939800 & -1.36281100 & 2.57479500 \\
\hline 1 & 0.64750300 & -4.92724200 & 1.97448600 & 6 & -2.24123700 & -2.90801600 & 1.38097300 \\
\hline 1 & -3.52290600 & -4.52970500 & -3.64709300 & 6 & -4.61380600 & -2.20522900 & -2.33418100 \\
\hline 1 & 2.05494400 & -3.73017800 & 3.66166500 & 6 & -2.51457300 & -2.41123800 & -3.49717500 \\
\hline 6 & 0.56742300 & 0.46638100 & 2.31290900 & 1 & -0.80402100 & -1.60981400 & -2.44237700 \\
\hline 1 & 0.96377700 & 0.90579200 & 1.37636500 & 6 & -0.72144100 & -2.30331600 & 3.61076000 \\
\hline 1 & -0.42216600 & 0.92473700 & 2.45749300 & 6 & -2.14503700 & -3.83206500 & 2.41823300 \\
\hline 1 & 1.21379800 & 0.79835500 & 3.13550900 & 1 & -2.83174900 & -3.16523400 & 0.49824100 \\
\hline 6 & -3.68144900 & -2.89516700 & 0.70228000 & 6 & -3.89193800 & -2.60968400 & -3.45410400 \\
\hline 1 & -4.41588500 & -2.08453100 & 0.83410400 & 1 & -5.69477400 & -2.37101100 & -2.30273600 \\
\hline 1 & -4.20685100 & -3.84008800 & 0.89430900 & 1 & -1.93349600 & -2.72416300 & -4.36751200 \\
\hline 1 & -2.92850000 & -2.76037400 & 1.49075900 & 6 & -1.38672300 & -3.52431700 & 3.54423700 \\
\hline 6 & -2.65367100 & 0.01073000 & 0.90632800 & 1 & -0.11153800 & -2.06705000 & 4.48740400 \\
\hline 6 & -3.57883300 & 0.78139200 & 0.15871000 & 1 & -2.66545100 & -4.78965700 & 2.34268800 \\
\hline 6 & -2.78301700 & -0.05303200 & 2.30059900 & 1 & -4.40909100 & -3.08416200 & -4.29173300 \\
\hline 6 & -4.58417800 & 1.46918600 & 0.85211300 & 1 & -1.30384700 & -4.23735800 & 4.36795800 \\
\hline 6 & -3.79216400 & 0.63611400 & 2.96743300 & 6 & 0.02525300 & -0.11316800 & 2.67606800 \\
\hline 1 & -2.08865900 & -0.67258000 & 2.87701700 & 1 & 0.90045900 & -0.16517400 & 2.00058400 \\
\hline
\end{tabular}




\begin{tabular}{|c|c|c|c|c|c|c|c|}
\hline 1 & -0.53210600 & 0.79313000 & 2.39779400 & 1 & 3.18583300 & 2.15487000 & 0.00001700 \\
\hline 1 & 0.40932900 & 0.02989800 & 3.69452700 & 1 & 0.70746100 & 2.15971000 & 0.00000700 \\
\hline 6 & -4.85321000 & -1.17539400 & -0.07508400 & 1 & 0.70751200 & -2.15973800 & -0.00003000 \\
\hline 1 & -5.12465300 & -0.10870100 & -0.12834500 & 1 & 3.18587000 & -2.15484900 & 0.00002400 \\
\hline 1 & -5.79147300 & -1.74549000 & -0.05743100 & 53 & -1.55529300 & -0.00000000 & 0.00000300 \\
\hline 1 & -4.35386800 & -1.31661600 & 0.89293900 & & & & \\
\hline 6 & -2.65580300 & 0.90162700 & 0.48627500 & & & & \\
\hline 6 & -2.96598700 & 1.88368100 & -0.48731300 & \multicolumn{2}{|c|}{ PhOTf } & & \\
\hline 6 & -3.07074400 & 1.09433100 & 1.81116800 & 16 & -1.22865700 & -0.89858600 & -0.11154400 \\
\hline 6 & -3.67086100 & 3.02438400 & -0.07862200 & 8 & -0.77475600 & -1.47746500 & 1.13411100 \\
\hline 6 & -3.77053600 & 2.23585500 & 2.19277000 & 8 & -2.20906300 & -1.49204300 & -0.98378900 \\
\hline 1 & -2.85834600 & 0.32427000 & 2.55904800 & 8 & 0.03616200 & -0.51482200 & -1.07470900 \\
\hline 6 & -4.06915100 & 3.20963200 & 1.24268500 & 6 & -1.81719800 & 0.82800200 & 0.27875200 \\
\hline 1 & -3.90924400 & 3.78596900 & -0.82728200 & 9 & -1.96620800 & 1.51913200 & -0.83895900 \\
\hline 1 & -4.08440500 & 2.35942300 & 3.23194400 & 9 & -2.97552600 & 0.74577900 & 0.91058100 \\
\hline 1 & -4.61556400 & 4.11190200 & 1.52740800 & 9 & -0.92930900 & 1.43275100 & 1.05356900 \\
\hline 6 & -2.59570800 & 1.72939300 & -1.92940500 & 6 & 1.29220600 & -0.22093600 & -0.53382200 \\
\hline 1 & -1.57854300 & 1.31976100 & -2.05792800 & 6 & 1.78596100 & 1.06617300 & -0.72428700 \\
\hline 1 & -3.27230900 & 1.03237500 & -2.45069900 & 6 & 2.03833300 & -1.20924100 & 0.10046500 \\
\hline 1 & -2.64388400 & 2.69052800 & -2.45811000 & 6 & 3.06749900 & 1.36769000 & -0.27017100 \\
\hline 8 & 3.02879000 & -1.09105000 & 1.06222900 & 1 & 1.16473400 & 1.80861800 & -1.22928000 \\
\hline 6 & 3.54512800 & -0.09550900 & 0.16602600 & 6 & 3.31494300 & -0.88879500 & 0.55709500 \\
\hline 1 & 3.43520900 & 0.86776400 & 0.69781400 & 1 & 1.61990700 & -2.20751400 & 0.23142900 \\
\hline 6 & 5.02055500 & -0.31880800 & -0.09745600 & 6 & 3.83135100 & 0.39352600 & 0.37241800 \\
\hline 6 & 5.97849400 & 0.38417000 & 0.64065800 & 1 & 3.46902000 & 2.37224300 & -0.41916300 \\
\hline 6 & 5.46068600 & -1.25606700 & -1.04107300 & 1 & 3.91197800 & -1.65326500 & 1.05872300 \\
\hline 6 & 7.34011500 & 0.15877700 & 0.44751400 & 1 & 4.83493300 & 0.63445100 & 0.72867700 \\
\hline 1 & 5.64547800 & 1.11895900 & 1.38031600 & & & & \\
\hline 6 & 6.82056800 & -1.49015000 & -1.23237600 & & & & \\
\hline 1 & 4.72523900 & -1.80184100 & -1.63991500 & $\mathrm{TfOH}$ & & & \\
\hline 6 & 7.76521900 & -0.78213300 & -0.48930500 & 16 & -0.85862700 & -0.14323100 & 0.08396100 \\
\hline 1 & 8.07379100 & 0.72088900 & 1.03071800 & 8 & -1.23638800 & -1.35445700 & -0.59522500 \\
\hline 1 & 7.14728900 & -2.22557600 & -1.97193900 & 8 & -1.23085200 & 0.20212200 & 1.43935800 \\
\hline \multirow[t]{3}{*}{1} & 8.83212000 & -0.96053900 & -0.64382300 & 8 & -1.23184700 & 1.08320300 & -0.90734300 \\
\hline & & & & 6 & 0.99442500 & -0.00473400 & -0.00393400 \\
\hline & & & & 9 & 1.34491600 & 1.24452000 & 0.28915400 \\
\hline $\mathrm{PhI}$ & & & & 9 & 1.52685800 & -0.83105900 & 0.87860700 \\
\hline 6 & 3.34614700 & 0.00001300 & 0.00001000 & 9 & 1.42055800 & -0.30552700 & -1.21547800 \\
\hline 6 & 2.64580900 & 1.20509100 & -0.00000600 & 1 & -1.26682100 & 1.90174100 & -0.38464000 \\
\hline 6 & 1.25129000 & 1.21331300 & -0.00000700 & & & & \\
\hline 6 & 0.56059000 & -0.00001600 & -0.00002400 & & & & \\
\hline 6 & 1.25130900 & -1.21332500 & -0.00001600 & $\mathrm{TfO}^{-}$ & & & \\
\hline 6 & 2.64583200 & -1.20507700 & 0.00001100 & 16 & 0.92941600 & 0.00014400 & -0.00140200 \\
\hline 1 & 4.43799400 & 0.00002300 & 0.00002100 & 8 & 1.23539400 & -0.07500400 & 1.43776700 \\
\hline
\end{tabular}




\begin{tabular}{|c|c|c|c|c|c|c|c|}
\hline 8 & 1.23226500 & -1.20991600 & -0.78589300 & & & & \\
\hline 8 & 1.23143400 & 1.28566700 & -0.65566500 & $\mathrm{Ph}_{2} \mathrm{I}$ & & & \\
\hline 6 & -0.93357700 & 0.00009000 & -0.00007400 & 53 & 0.89593500 & -0.88831200 & -0.44321700 \\
\hline 9 & -1.44494500 & 0.06075000 & -1.24290600 & 6 & 2.96507300 & -0.40469000 & -0.03151500 \\
\hline 9 & -1.43618100 & -1.10967600 & 0.57157300 & 6 & 3.45211400 & 0.90057400 & -0.05149500 \\
\hline 9 & -1.43686700 & 1.04794400 & 0.67724400 & 6 & 3.80450500 & -1.48239600 & 0.25184000 \\
\hline & & & & 6 & 4.80278000 & 1.12255400 & 0.22188200 \\
\hline & & & & 1 & 2.79410500 & 1.74510800 & -0.27150500 \\
\hline & & & & 6 & 5.15359100 & -1.24717400 & 0.51559500 \\
\hline hydro & yen-iodide & & & 1 & 3.41995000 & -2.50651600 & 0.27889800 \\
\hline 53 & 0.00000000 & 0.00000000 & 0.02985500 & 6 & 5.65243200 & 0.05422000 & 0.50367400 \\
\hline 1 & 0.00000000 & 0.00000000 & -1.58233100 & 1 & 5.18960600 & 2.14419600 & 0.21198400 \\
\hline & & & & 1 & 5.81269300 & -2.08855800 & 0.74064800 \\
\hline & & & & 1 & 6.70763900 & 0.23676400 & 0.71705400 \\
\hline iodob & nzene & & & 8 & -1.52893400 & -1.17765800 & -0.91430900 \\
\hline 6 & 3.34614700 & 0.00001300 & 0.00001000 & 16 & -2.40180700 & -1.30303300 & 0.32375000 \\
\hline 6 & 2.64580900 & 1.20509100 & -0.00000600 & 8 & -1.68222000 & -0.88602300 & 1.53781400 \\
\hline 6 & 1.25129000 & 1.21331300 & -0.00000700 & 8 & -3.20095200 & -2.51799100 & 0.36373000 \\
\hline 6 & 0.56059000 & -0.00001600 & -0.00002400 & 6 & -3.62710100 & 0.05803800 & 0.03627200 \\
\hline 6 & 1.25130900 & -1.21332500 & -0.00001600 & 9 & -4.43463800 & 0.16720900 & 1.08784200 \\
\hline 6 & 2.64583200 & -1.20507700 & 0.00001100 & 9 & -3.00111200 & 1.22916800 & -0.13000600 \\
\hline 1 & 4.43799400 & 0.00002300 & 0.00002100 & 9 & -4.36600600 & -0.17648500 & -1.04342600 \\
\hline 1 & 3.18583300 & 2.15487000 & 0.00001700 & 6 & 0.23411400 & 1.10076200 & -0.15831100 \\
\hline 1 & 0.70746100 & 2.15971000 & 0.00000700 & 6 & 0.01950100 & 1.88460600 & -1.28725800 \\
\hline 1 & 0.70751200 & -2.15973800 & -0.00003000 & 6 & 0.02038000 & 1.55744800 & 1.13737300 \\
\hline 1 & 3.18587000 & -2.15484900 & 0.00002400 & 6 & -0.40758700 & 3.19869000 & -1.09985400 \\
\hline 53 & -1.55529300 & -0.00000000 & 0.00000300 & 1 & 0.16824900 & 1.48525800 & -2.29195100 \\
\hline & & & & 6 & -0.40193600 & 2.87696900 & 1.29775700 \\
\hline & & & & 1 & 0.14997800 & 0.90015600 & 1.99713800 \\
\hline $\mathrm{AcO}^{-}$ & & & & 6 & -0.61188000 & 3.69278900 & 0.18746600 \\
\hline 6 & -0.22051700 & 0.00191000 & -0.00001100 & 1 & -0.58778800 & 3.83247200 & -1.97057000 \\
\hline 6 & 1.34429100 & -0.06067800 & -0.00000500 & 1 & -0.58214900 & 3.25864900 & 2.30482200 \\
\hline 1 & 1.73443300 & -1.09219200 & -0.00023800 & 1 & -0.95115800 & 4.72153300 & 0.32586100 \\
\hline 1 & 1.74656300 & 0.47078800 & -0.87989300 & & & & \\
\hline 1 & 1.74647900 & 0.47033600 & 0.88019900 & & & & \\
\hline 8 & -0.68626900 & 1.16239600 & 0.00000100 & & & & \\
\hline 8 & -0.80999600 & -1.09943600 & 0.00000200 & & & & \\
\hline
\end{tabular}

\section{References}

[1] Xie, Y.; Hu, J.; Xie, P.; Qian, B.; Huang, H. J. Am. Chem. Soc. 2013, 135, 18327.

[2] (a) Ma, X.-P.; Li, K.; Wu, S.-Y.; Liang, C.; Su, G.-F.; Mo, D.-L. Green Chem., 2017, 19, 5761.; (b) Ma, X.-P.; Shi, W.-M.; Li, X.-H.; Li, L.-G.; Pan, C.-X.; Chen, 
B.; Su, G.-F.; Mo, D.-L. J. Org. Chem., 2015, 80, 10098.

[3] (a) Ge, G.-C.; Mo, D.-L.; Ding, C.-H.; Dai, L.-X.; Hou, X.-L. Org. Lett., 2012, 14, 5756; (b) Mo, D.-L.; Chen, B.; Ding, C.-H.; Dai, L.-X.; Ge, G.-C.; Hou, X.-L. Organometallics. 2013, 32, 4465.

[4] Risi, C.; Zhao, F.; Castagnolo, D. ACS Catal., 2019, 9, 7264.

[5] Wang, Y.; Zheng, K.; Hong, R. J. Am. Chem. Soc., 2012, 134, 4096.

[6] Hu, J.; Lu, Y.; Li, Y.; Zhou, J. Chem. Commun., 2013, 49, 9425.

[7] Lauer, M. G.; Thompson, M. K.; Shaughnessy, K. H. J. Org. Chem., 2014, 79, 10837.

[8] Wu, C.; Zhou, J. J. Am. Chem. Soc., 2014, 136, 650.

[9] Wu, W.-Q.; Peng, Q.; Dong, D.-X.; Hou, X.-L.; Wu, Y.-D. J. Am. Chem. Soc., 2008, 130, 9717.

[10] Yang, B.; Zhu, C. Qiu, Y.; Backvall, J.-E. Angew. Chem. Int. Ed., 2016, 55, 5568.

[11] Li, H.; Wan, S.-L.; Ding, C.-H.; Xu, B.; Hou, X.-L. RSC Adv., 2015, 5, 75411.

[12] Huang, X.; Teng, S.; Chi, Y. R.; Xu, W.; Pu, M.; Wu, Y.-D.; Zhou, J. S. Angew. Chem. Int. Ed., 2021, 60, 2828.

[13] Hii, K. K.; Claridge, T. D. W.; Brown, J. M.; Smith, A.; Deeth, R. J. Helvetica, 2001, 84, 3043.

[14] (a) Shao, M.; Zheng, L.; Qiao, W.; Wang, J.; Wang, J. Adv. Synth. Catal., 2012, 354, 2743. (b) Wang, Y.-B.; Liu, L.; B.-Y.; Bu, Q.; Dai, B.; Liu, N, J. Adv. Synth. Catal., 2020, 362, 2930.

[15] Frisch, M. J.; Trucks, G. W.; Schlegel, H. B.; Scuseria, G. E.; Robb, M. A.; Cheeseman, J. R.; Scalmani, G.; Barone, V.; Petersson, G. A.; Nakatsuji, H.; Li, X.; Caricato, M.; Marenich, A. V.; Bloino, J.; Janesko, B. G.; Gomperts, R.; Mennucci, B.; Hratchian, H. P.; Ortiz, J. V.; Izmaylov, A. F.; Sonnenberg, J. L.; Williams; Ding, F.; Lipparini, F.; Egidi, F.; Goings, J.; Peng, B.; Petrone, A.; Henderson, T.; Ranasinghe, D.; Zakrzewski, V. G.; Gao, J.; Rega, N.; Zheng, G.; Liang, W.; Hada, M.; Ehara, M.; Toyota, K.; Fukuda, R.; Hasegawa, J.; Ishida, M.; Nakajima, T.; Honda, Y.; Kitao, O.; Nakai, H.; Vreven, T.; Throssell, K.; Montgomery Jr., J. A.; Peralta, J. E.; Ogliaro, F.; Bearpark, M. J.; Heyd, J. J.; Brothers, E. N.; Kudin, K. 
N.; Staroverov, V. N.; Keith, T. A.; Kobayashi, R.; Normand, J.; Raghavachari, K.; Rendell, A. P.; Burant, J. C.; Iyengar, S. S.; Tomasi, J.; Cossi, M.; Millam, J. M.; Klene, M.; Adamo, C.; Cammi, R.; Ochterski, J. W.; Martin, R. L.; Morokuma, K.; Farkas, O.; Foresman, J. B.; Fox, D. J. Gaussian 16 Rev. A.03, Wallingford, CT, 2016.

[16]Zhao, Y.; Truhlar, D. G., Theor. Chem. Acc. 2008, 120, 215.

[17]Weigend, F.; Ahlrichs, R., Phys. Chem. Chem. Phys. 2005, 7, 3297.

[18]Marenich, A. V.; Cramer, C. J.; Truhlar, D. G., J. Phys. Chem. B 2009, 113, 6378.

[19]Liang, Y.; Liu, S.; Xia, Y.; Li, Y.; Yu, Z.-X., Chem.-Eur. J. 2008, 14, 4361.

[20] Legault, C. Y., CYLview, 1.0b; Université de Sherbrooke, 2009, Online at http://www.cylview.org.

12. NMR spectra of compounds 3aa-3ba, 4aa-4ar, D-1a, D-3ag, and 7 


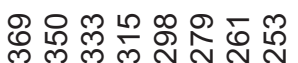

ヘ

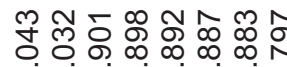

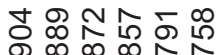

0

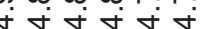

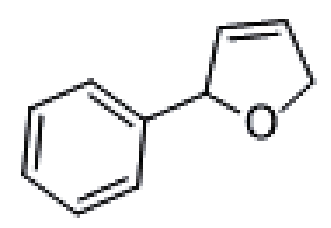

3aa

$\left(500 \mathrm{MHz}, \mathrm{CDCl}_{3}\right.$ )

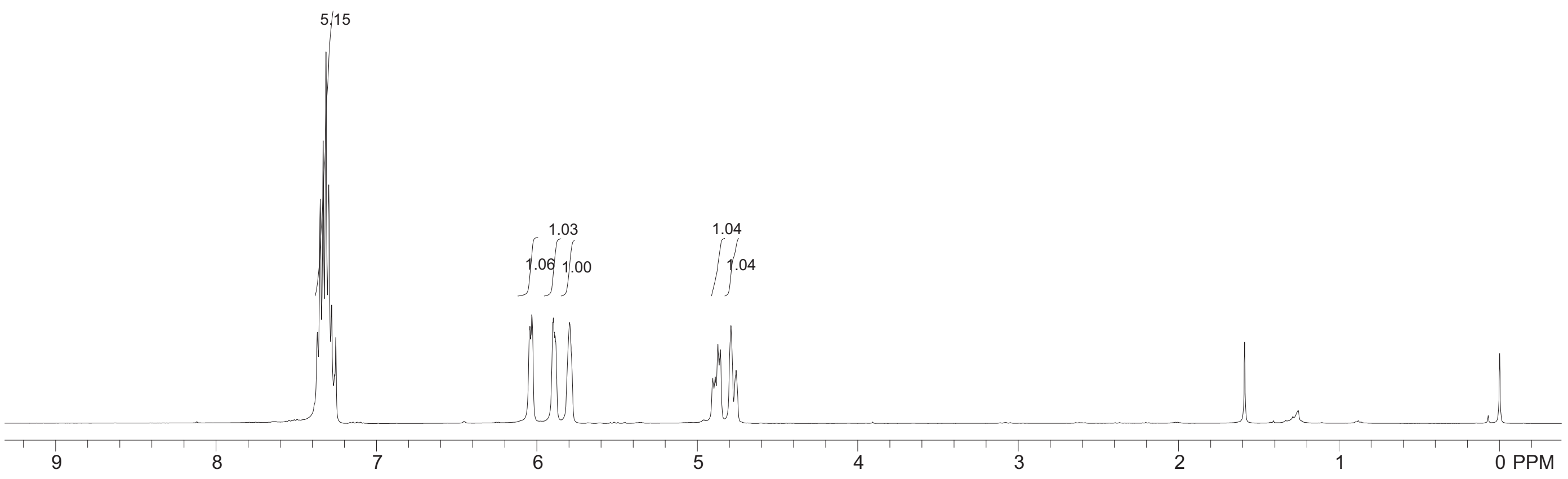



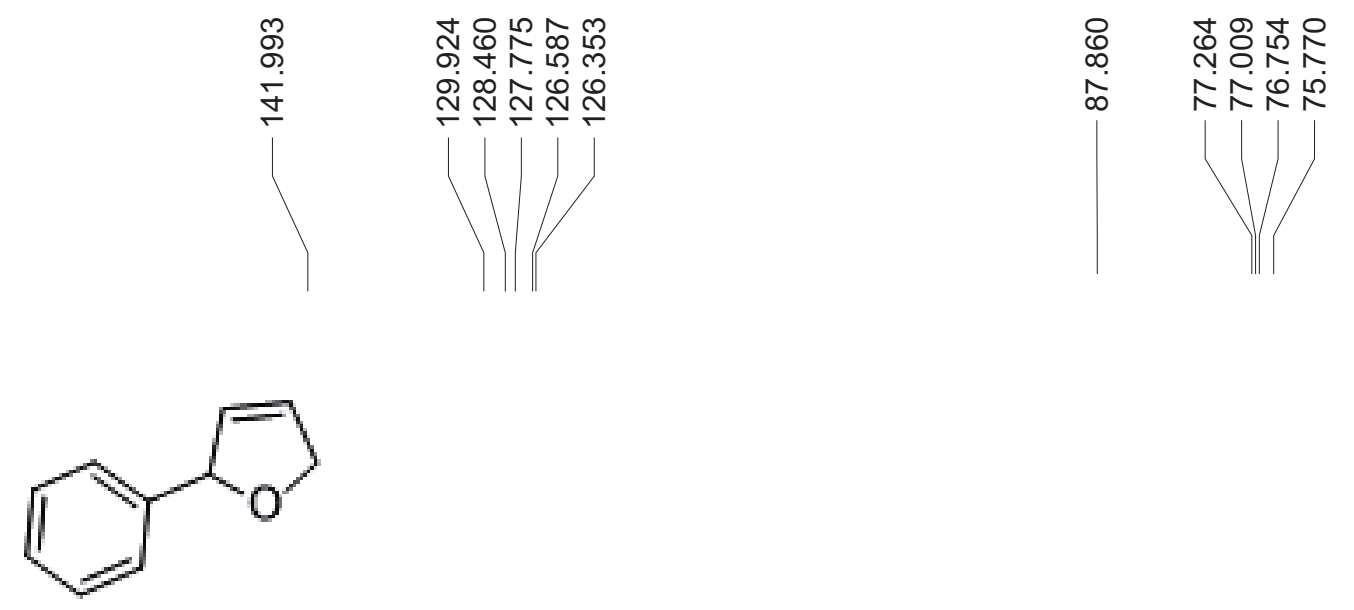

3 aa

(125 MHz, $\mathrm{CDCl}_{3}$ )

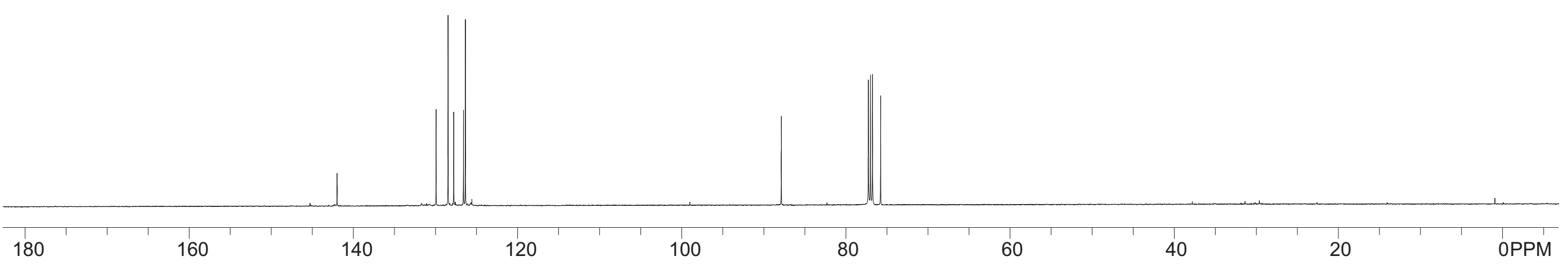




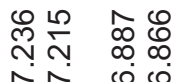

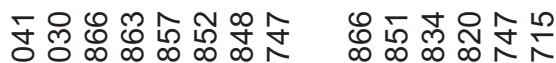
ல்

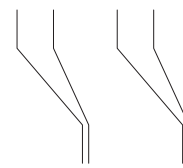<smiles>COc1ccc(C2C=CCO2)cc1</smiles>

3ab

(400 MHz, $\mathrm{CDCl}_{3}$ )

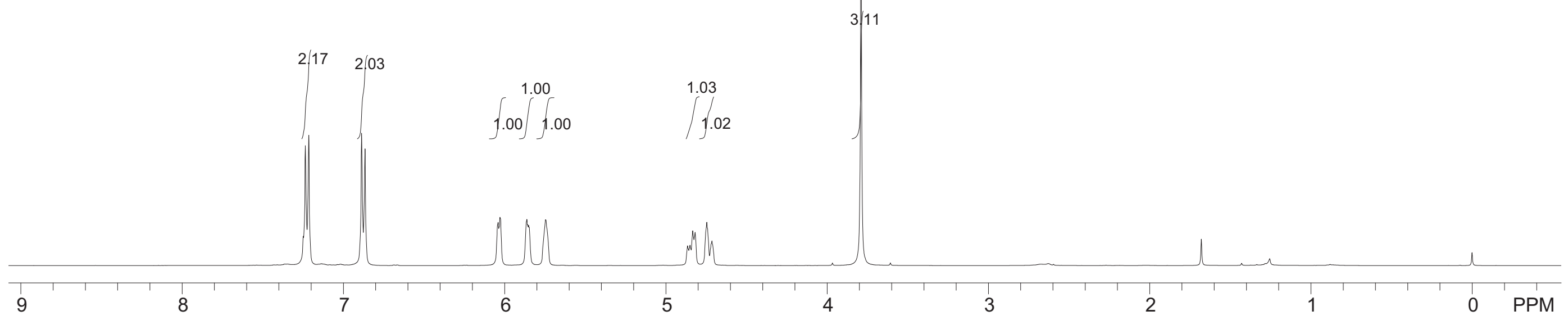




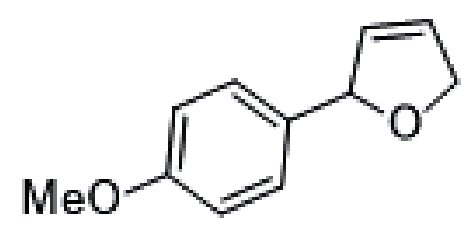

3ab

(100 MHz, $\mathrm{CDCl}_{3}$ )

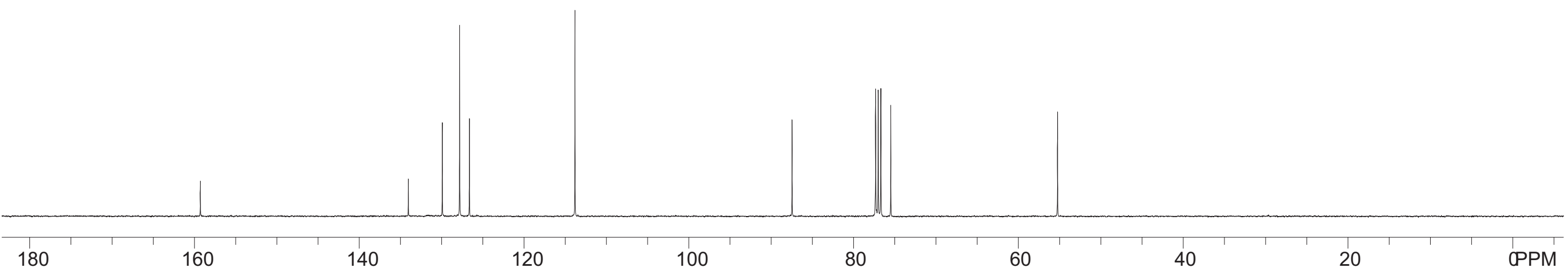




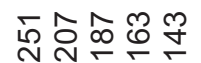

ペベ

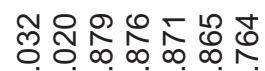

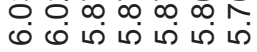

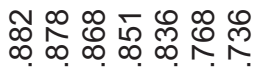

守守守守莳<smiles>Cc1ccc(C2C=CCO2)cc1</smiles>

$3 a c$

$\left(400 \mathrm{MHz}, \mathrm{CDCl}_{3}\right.$ )

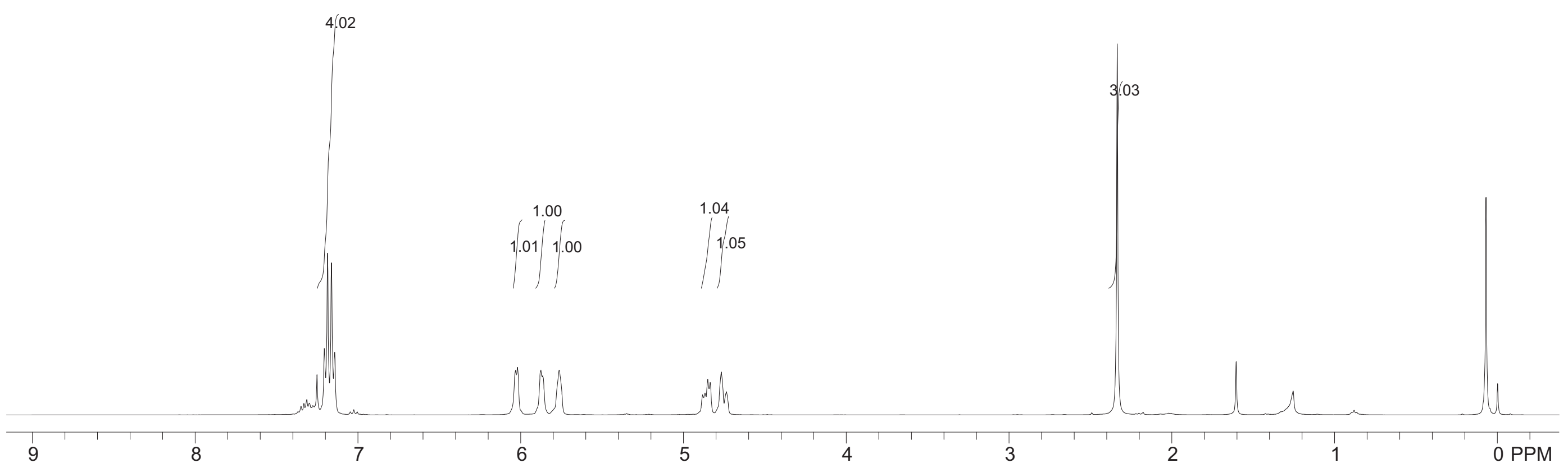




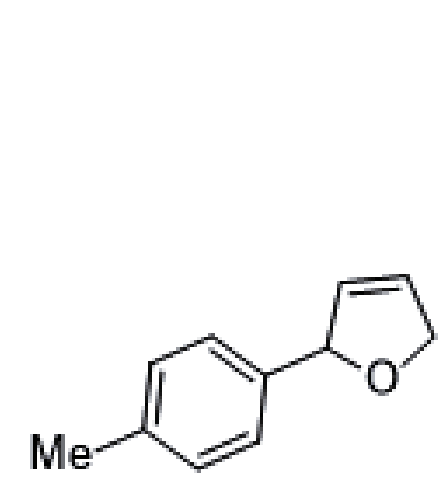

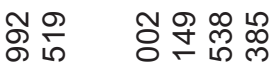

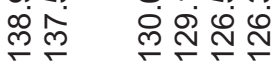

\section{$3 a c$}

$\left(100 \mathrm{MHz}, \mathrm{CDCl}_{3}\right)$

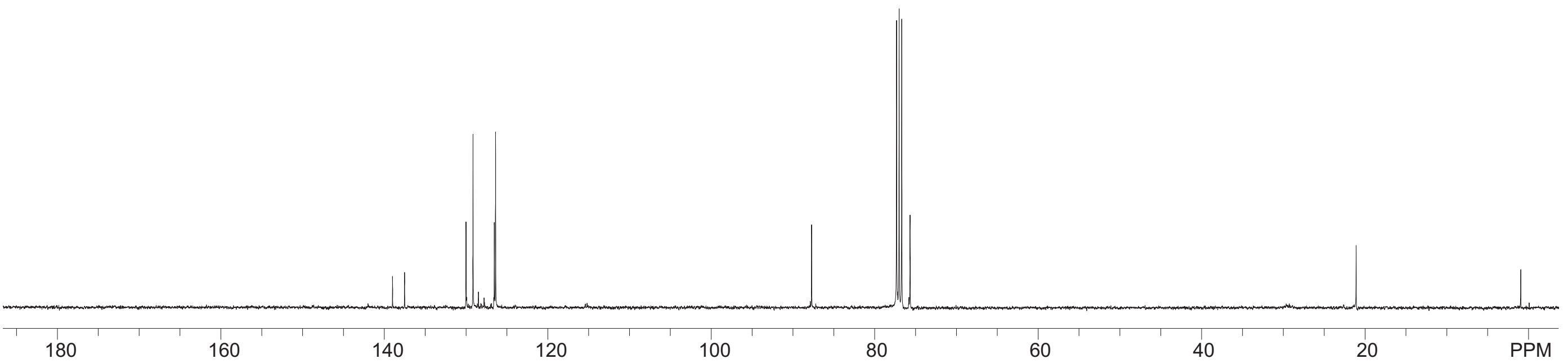


<smiles>CCc1ccc(C2C=CCO2)cc1</smiles>

\section{3ad}

(400 MHz, $\mathrm{CDCl}_{3}$ )

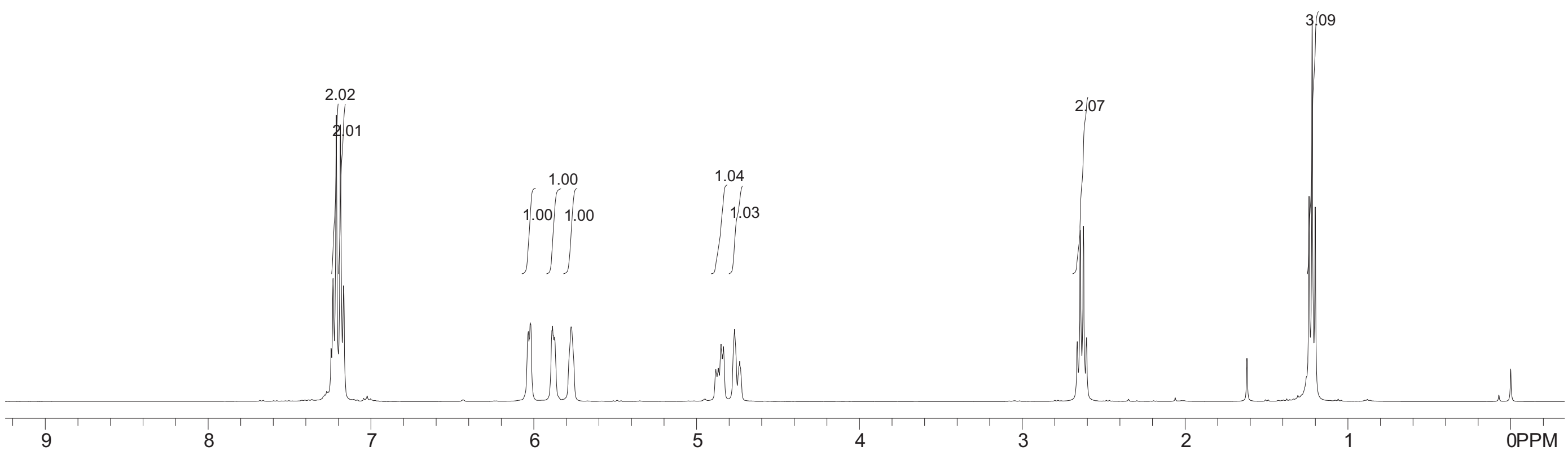




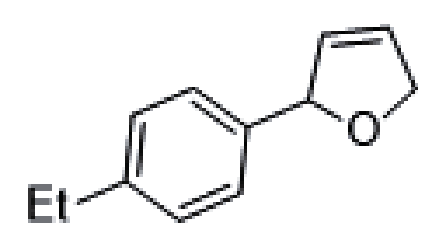

3ad

(100 MHz, $\mathrm{CDCl}_{3}$ )

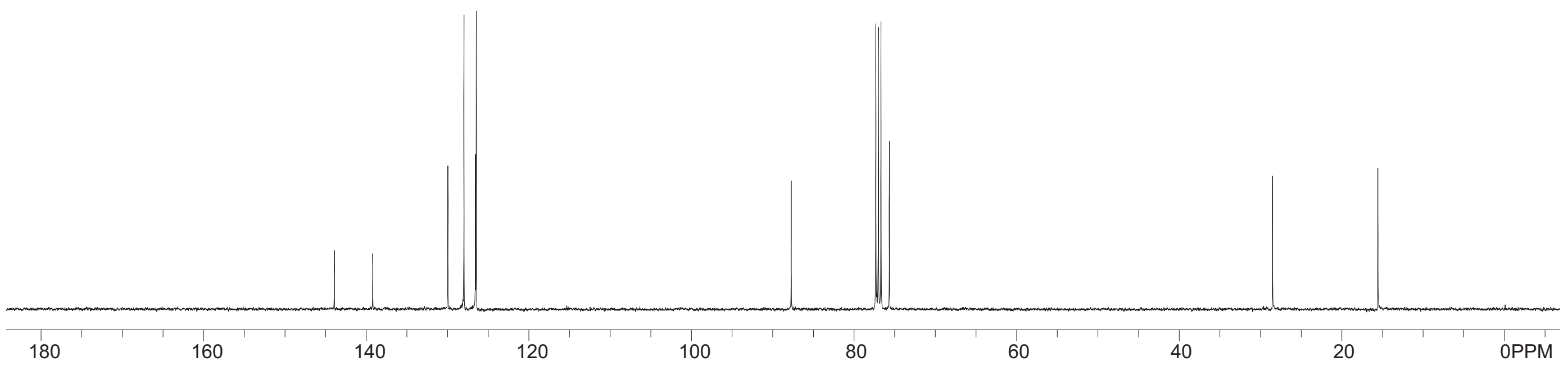




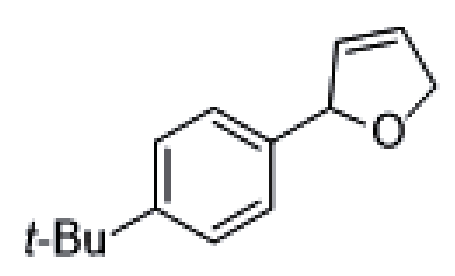

$3 a e$

(400 MHz, $\mathrm{CDCl}_{3}$ )

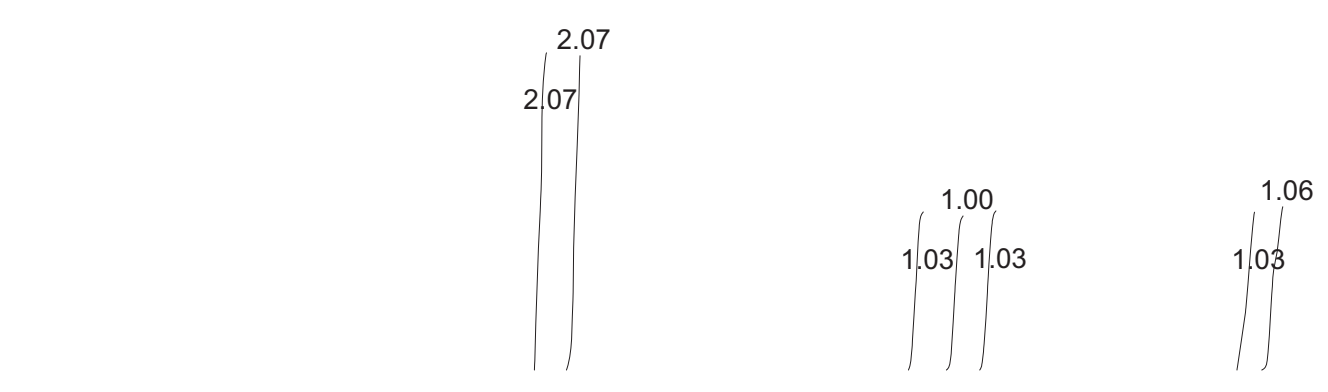




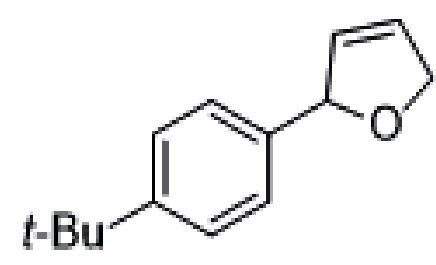

$3 a e$

$\left(100 \mathrm{MHz}, \mathrm{CDCl}_{3}\right.$ )

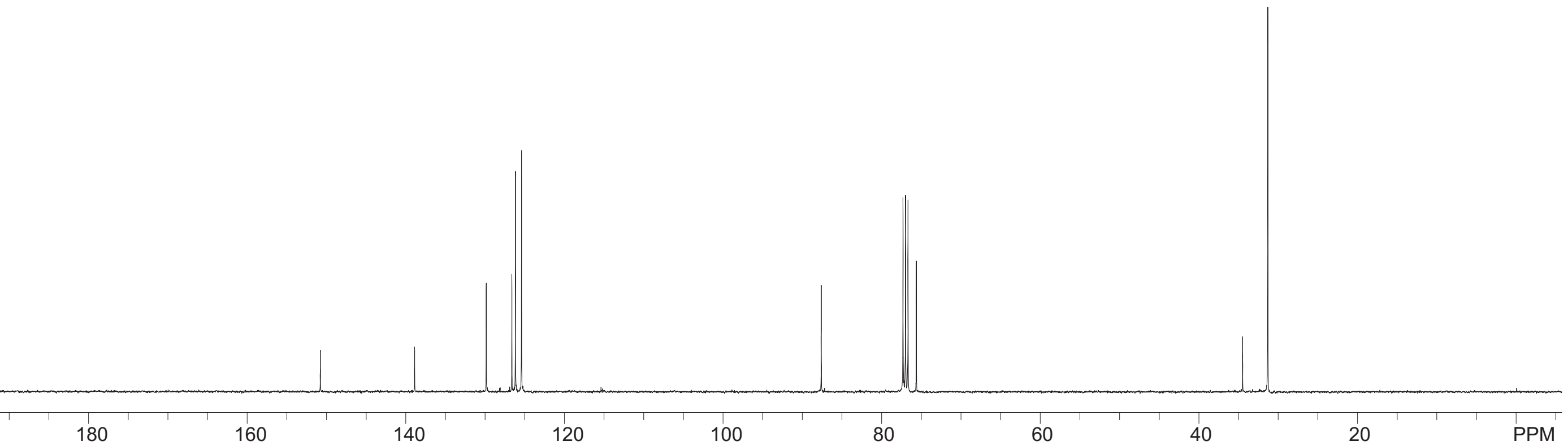




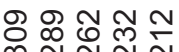

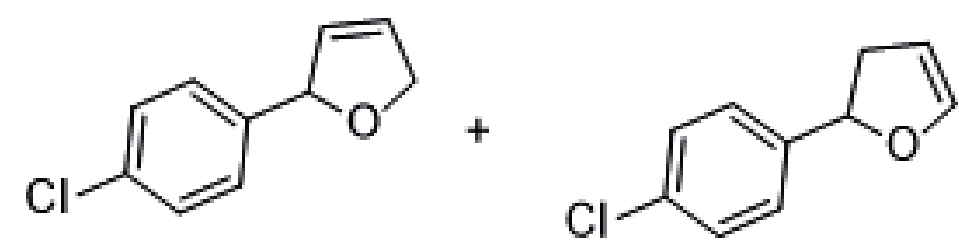

3af

major 3af (isomer ratio $=10: 1$ )

$\left(400 \mathrm{MHz}, \mathrm{CDCl}_{3}\right.$ )

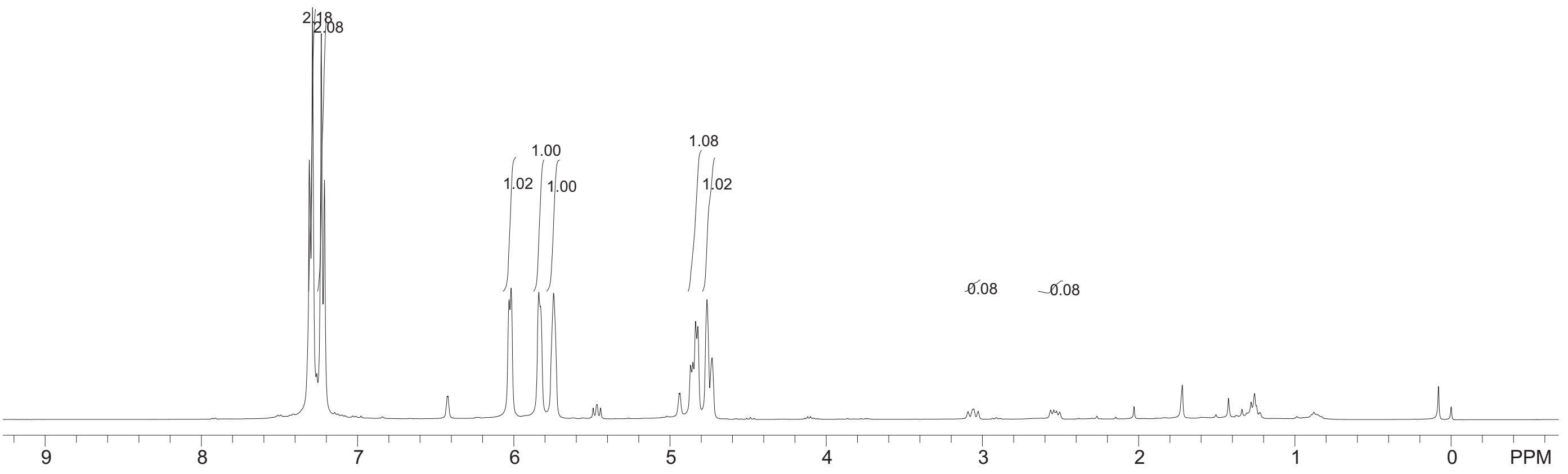




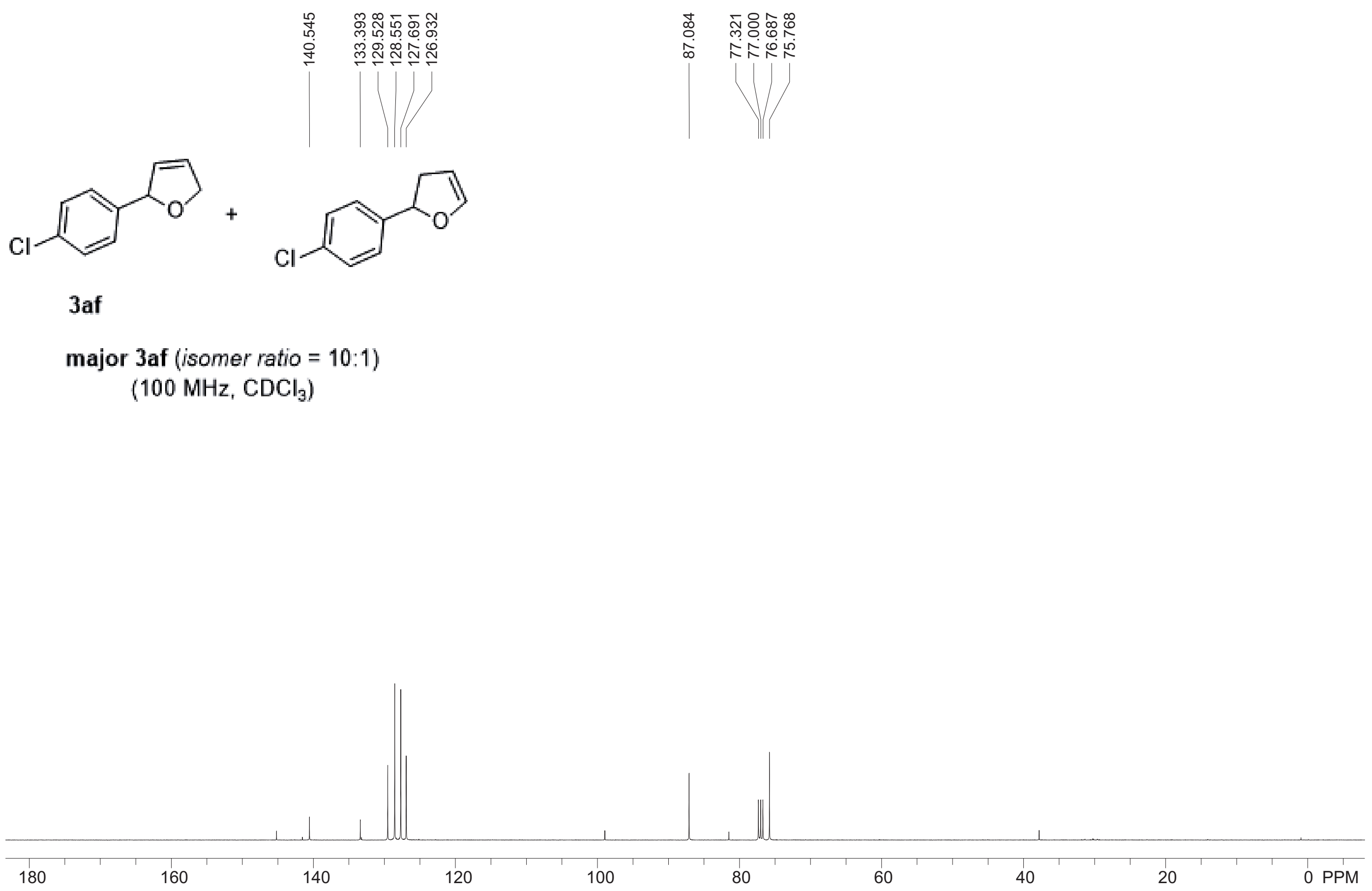




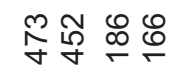

穴穴<smiles>Brc1ccc(C2C=CCO2)cc1</smiles>

3ag

(400 MHz, $\mathrm{CDCl}_{3}$ )

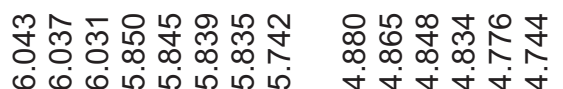

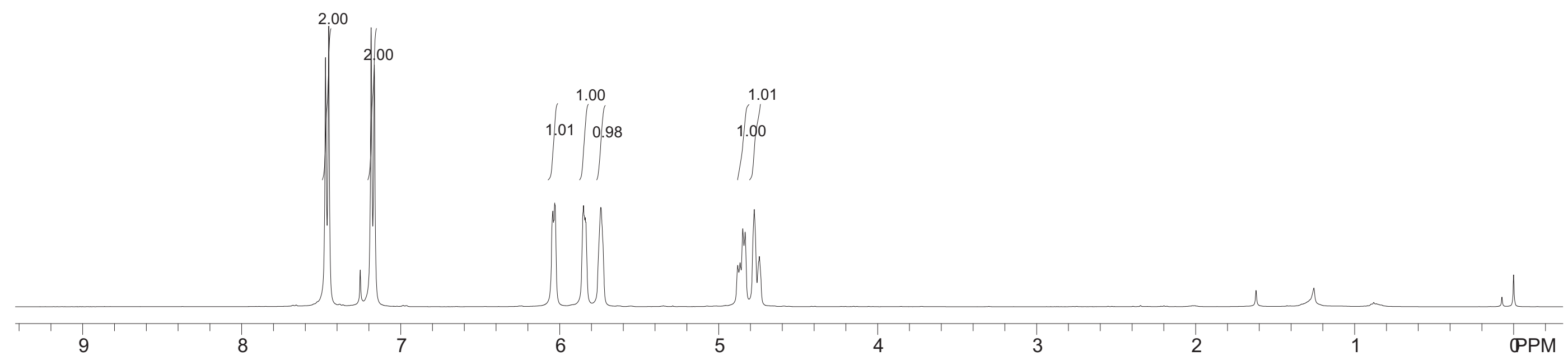



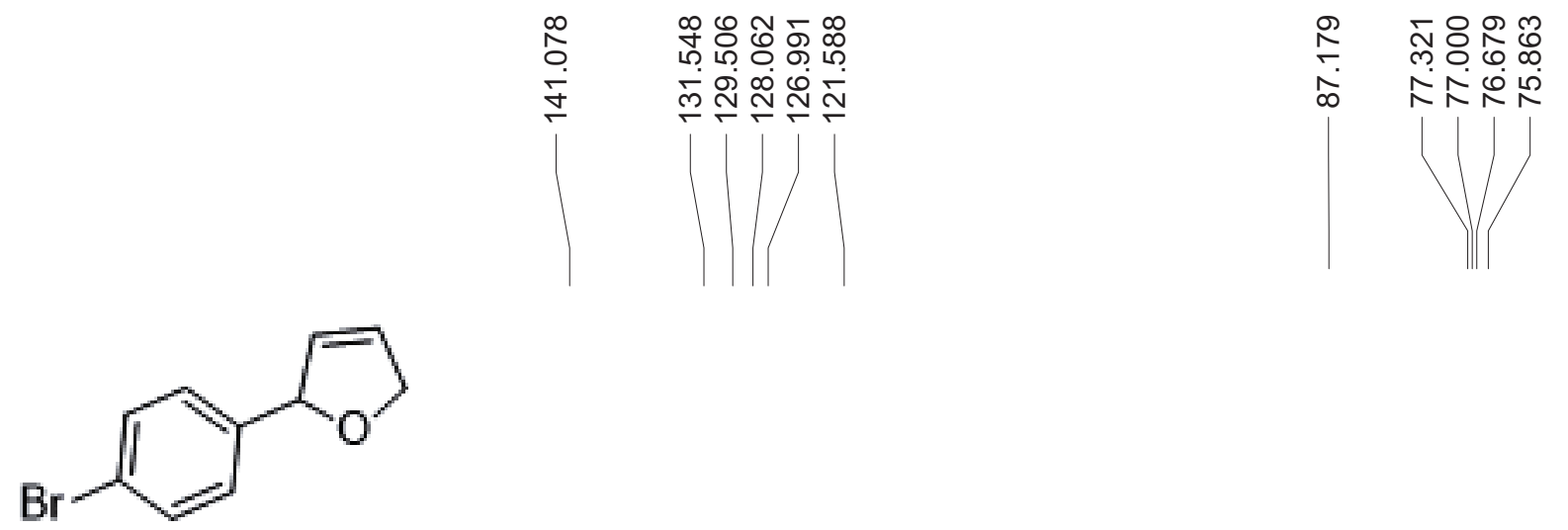

$3 a g$

$\left(100 \mathrm{MHz}, \mathrm{CDCl}_{3}\right.$ )

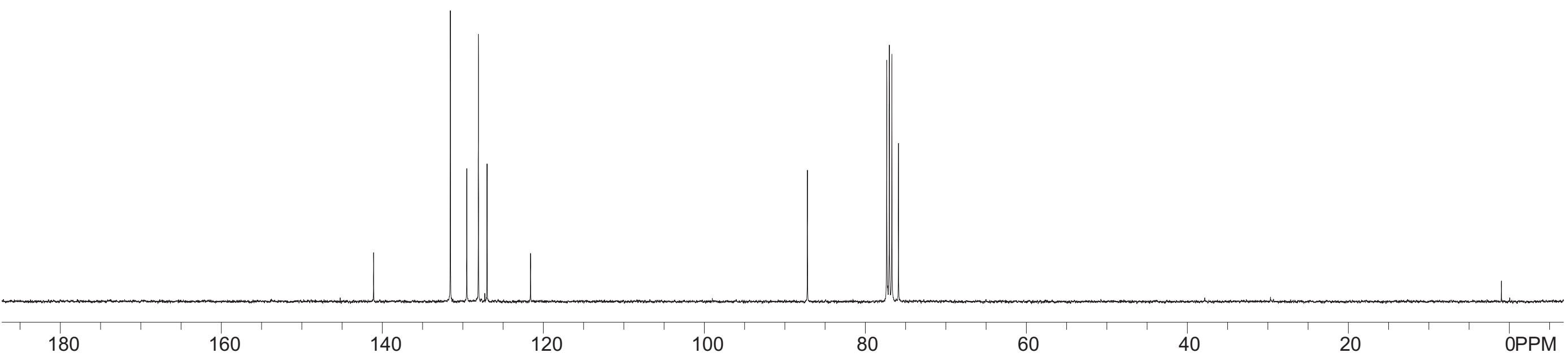



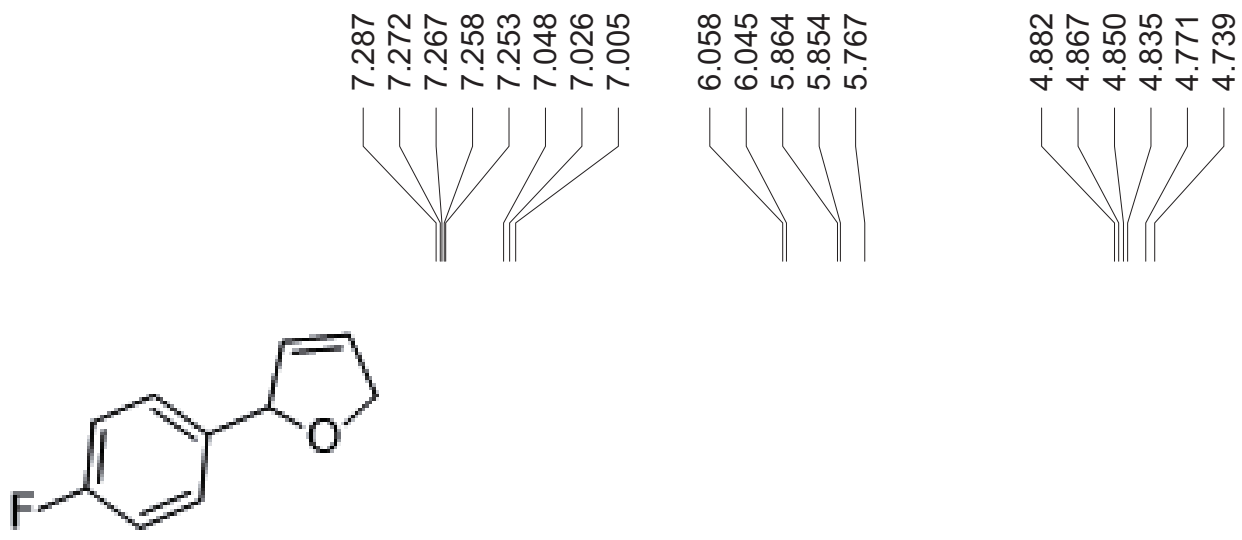

3ah

(400 MHz, $\mathrm{CDCl}_{3}$ )

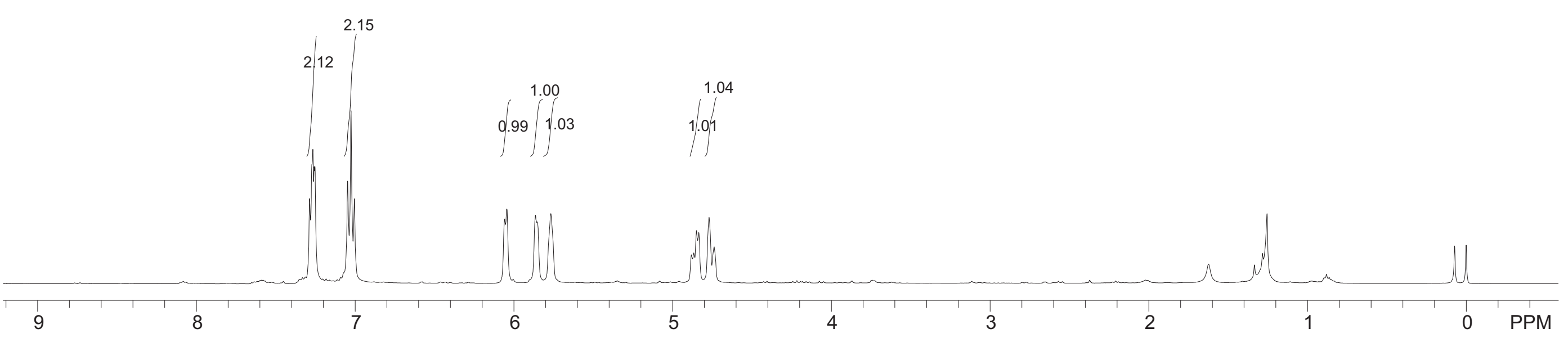


串 용

후

$\mid$<smiles>Fc1ccc(C2C=CCO2)cc1</smiles>

3ah

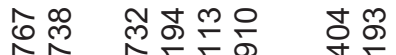

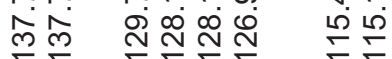

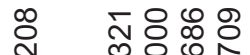

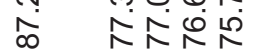

(100 MHz, $\mathrm{CDCl}_{3}$ )

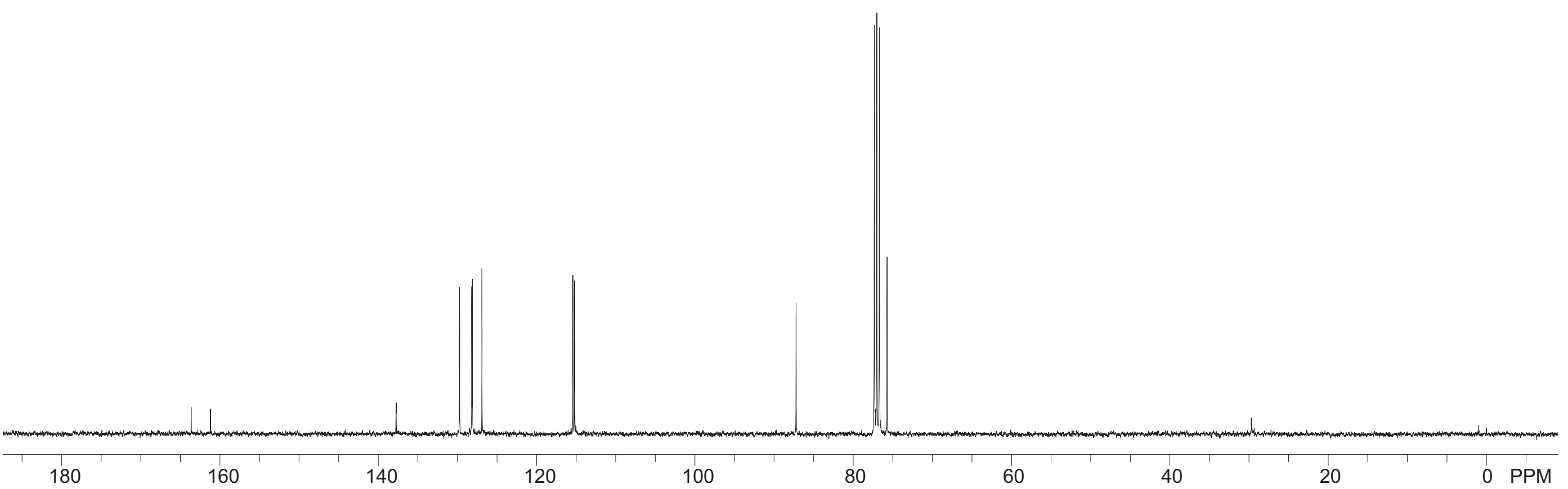




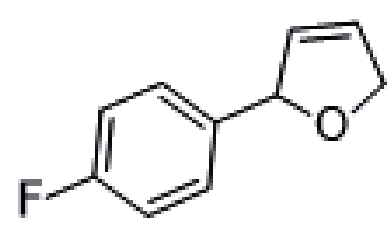

3ah

(376 MHz, $\mathrm{CDCl}_{3}$ ) 
<smiles>FC(F)(F)c1ccc(C2C=CCO2)cc1</smiles>

3ai

(400 MHz, $\mathrm{CDCl}_{3}$ )

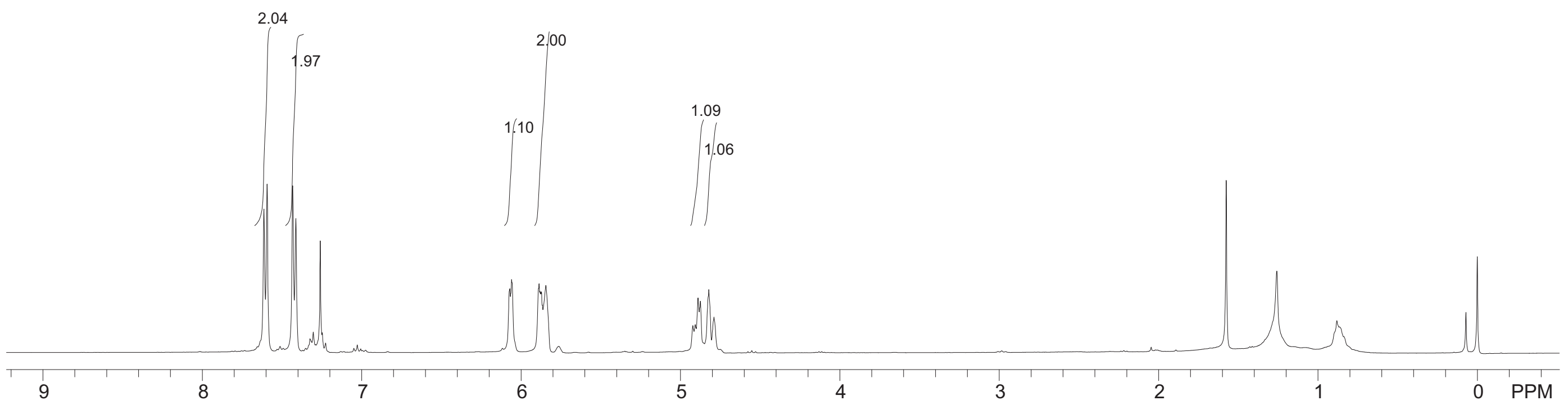




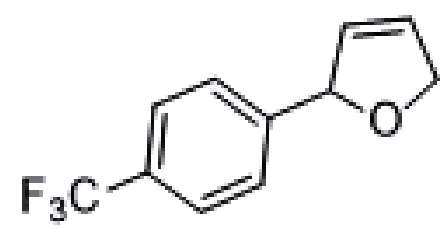

3ai

$\left(100 \mathrm{MHz}, \mathrm{CDCl}_{3}\right)$

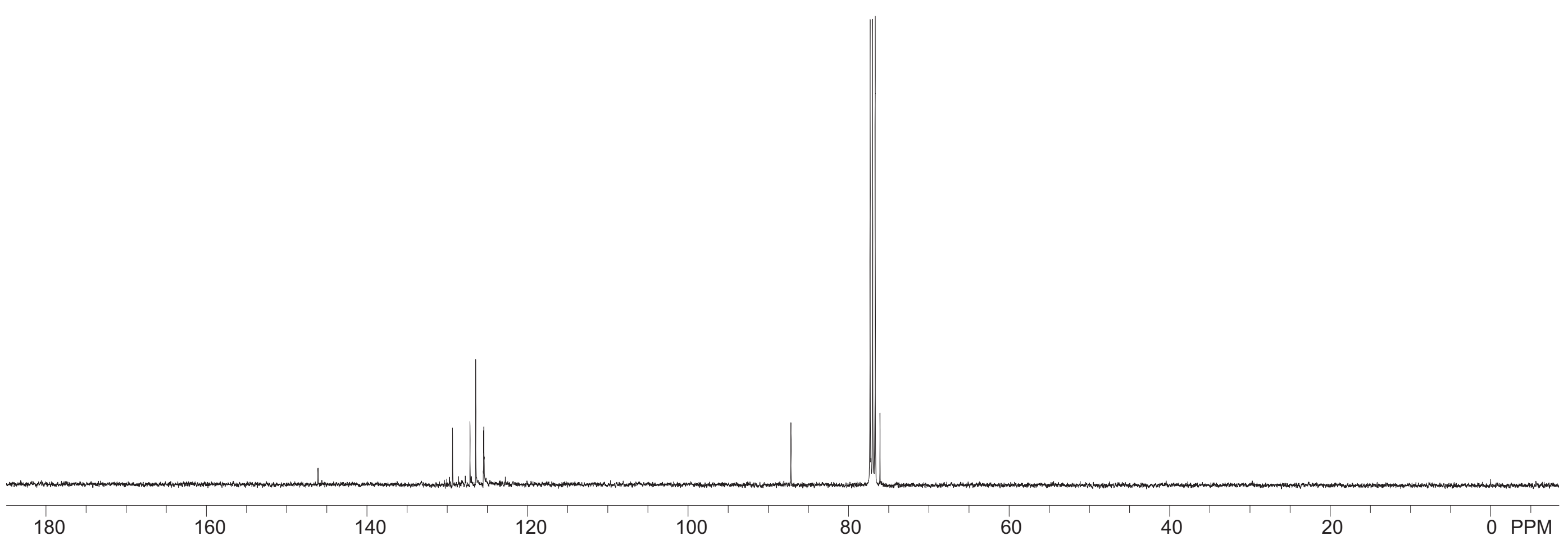


<smiles>FC(F)(F)c1ccc(C2C=CCO2)cc1</smiles>

3ai

(376 MHz, $\mathrm{CDCl}_{3}$ )

0

$-20$

$-40$

$-60$

$-80$

$-100$

$-120$

$-140$

PPM 


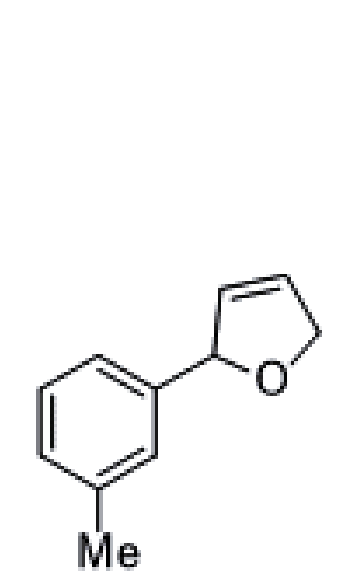

ำ ํํำ둥

œొ

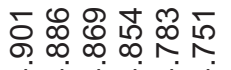

3aj

(400 MHz, $\mathrm{CDCl}_{3}$ )

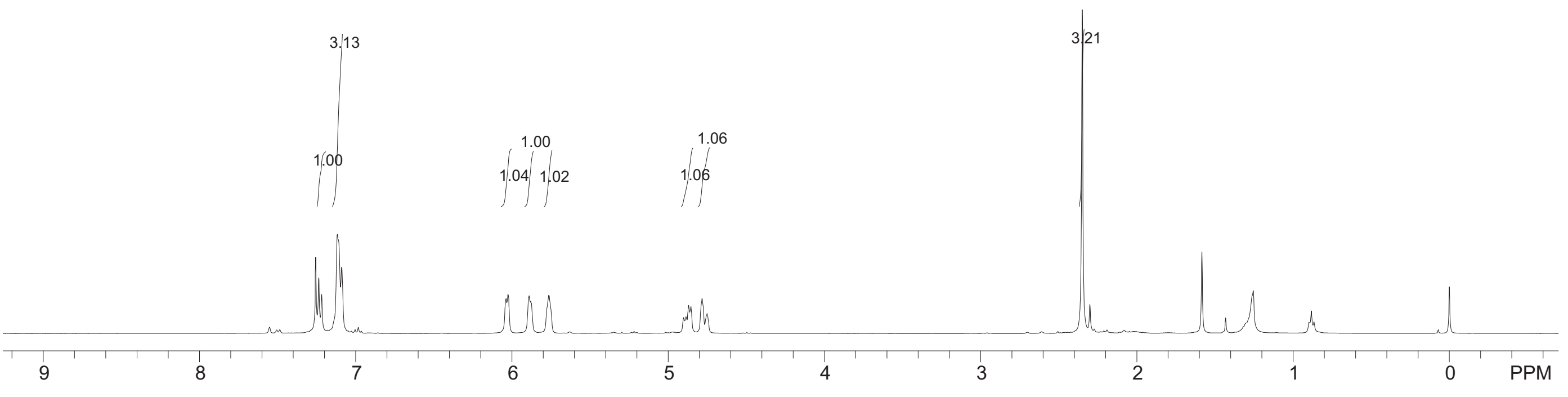


<smiles>Cc1cccc(C2C=CCO2)c1</smiles>

3aj

$\left(100 \mathrm{MHz} \mathrm{CDCl}_{3}\right)$ 


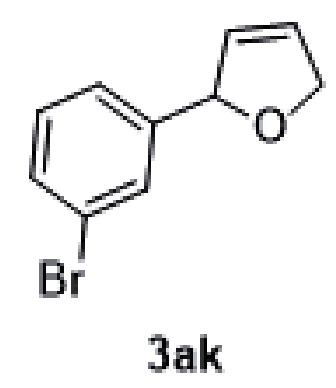

(400 MHz, $\mathrm{CDCl}_{3}$ )

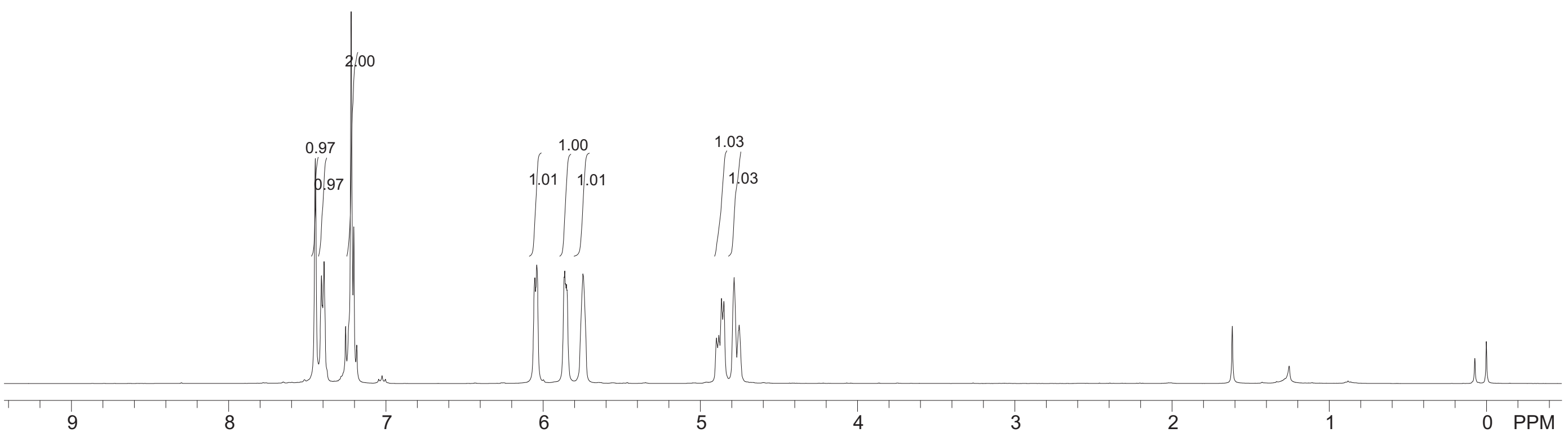




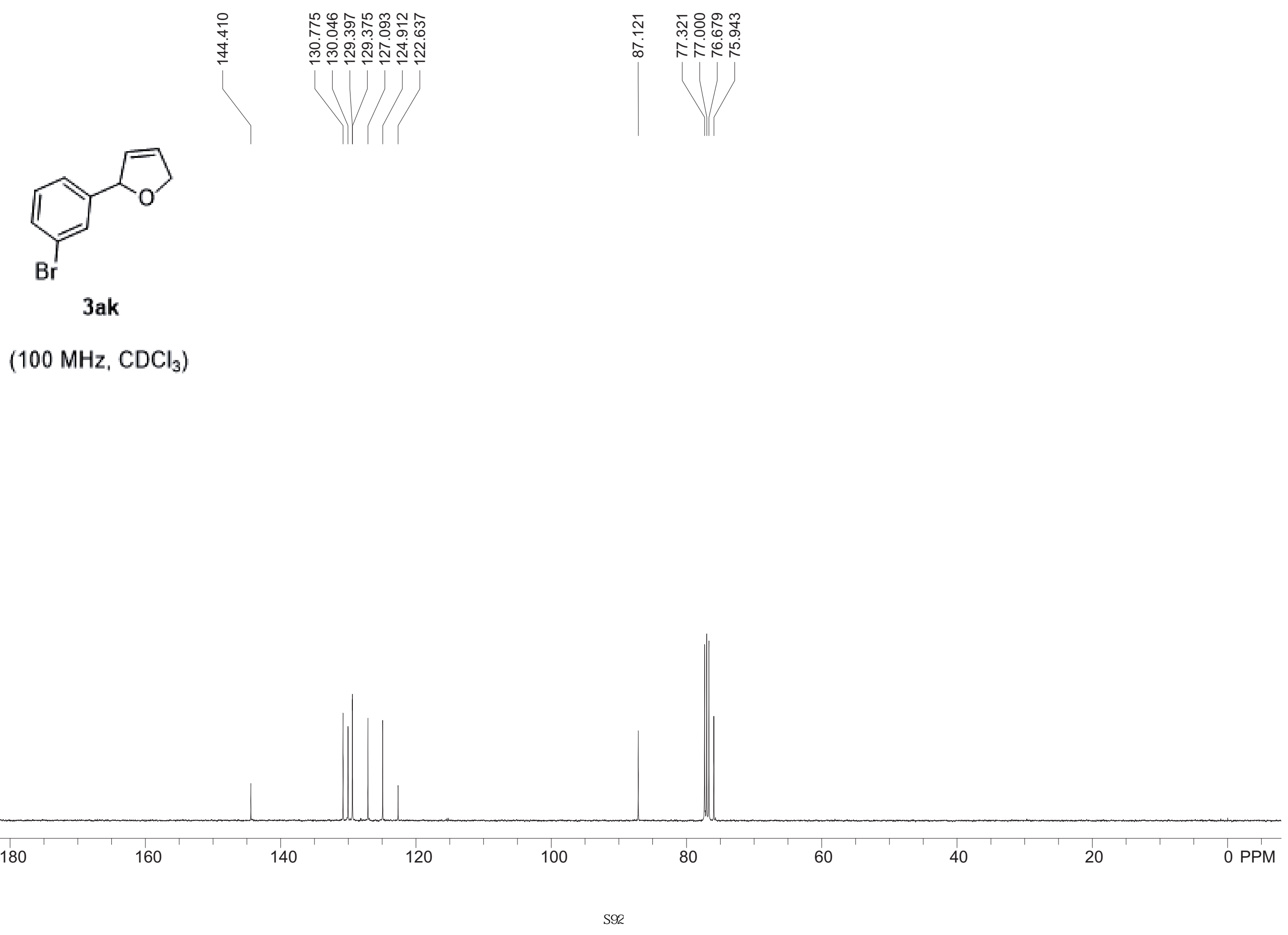


<smiles>Cc1ccccc1C1C=CCO1</smiles>

3al

(400 MHz, $\mathrm{CDCl}_{3}$ )

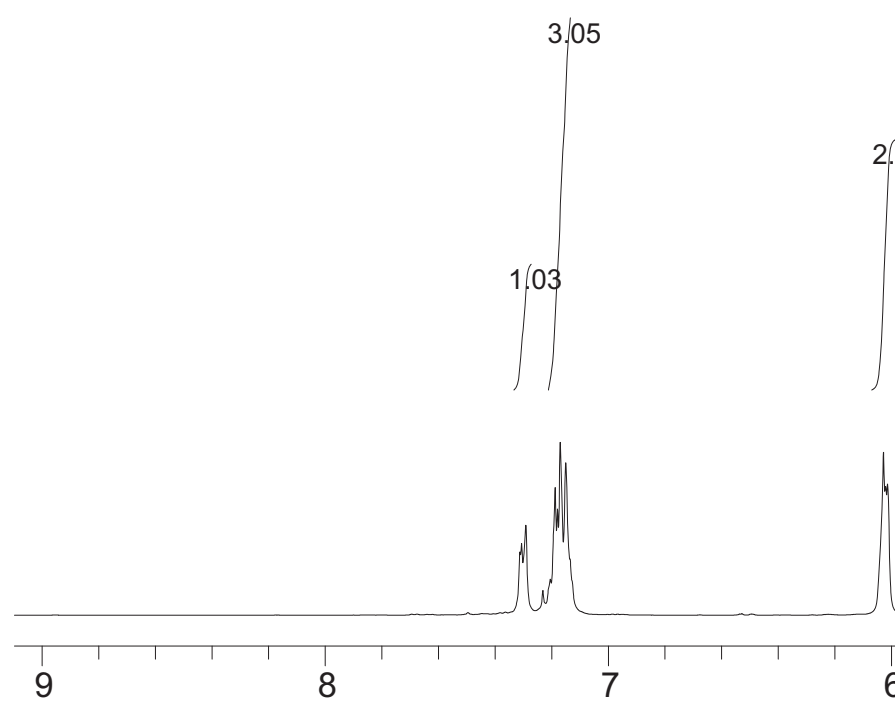

2.04

1.00 


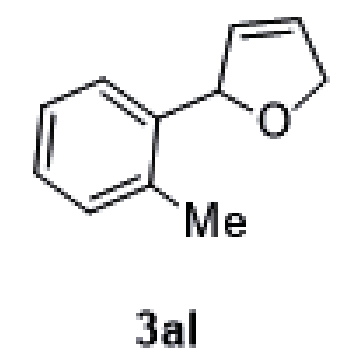

$\left(100 \mathrm{MHz}, \mathrm{CDCl}_{3}\right.$ )

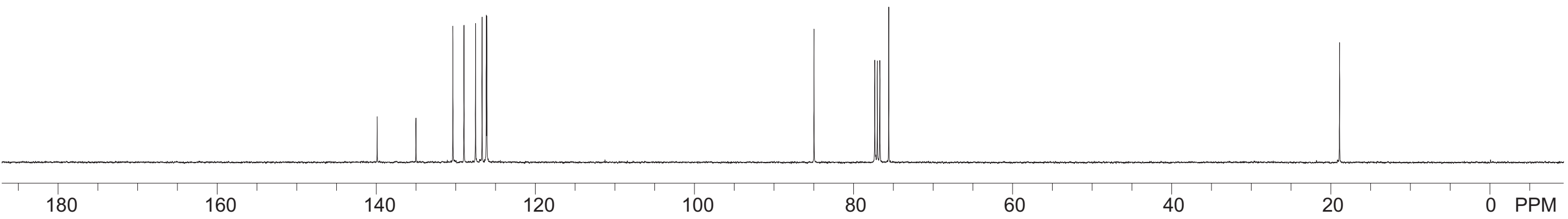




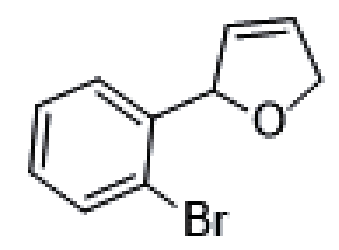

3am

(400 MHz, $\mathrm{CDCl}_{3}$ )

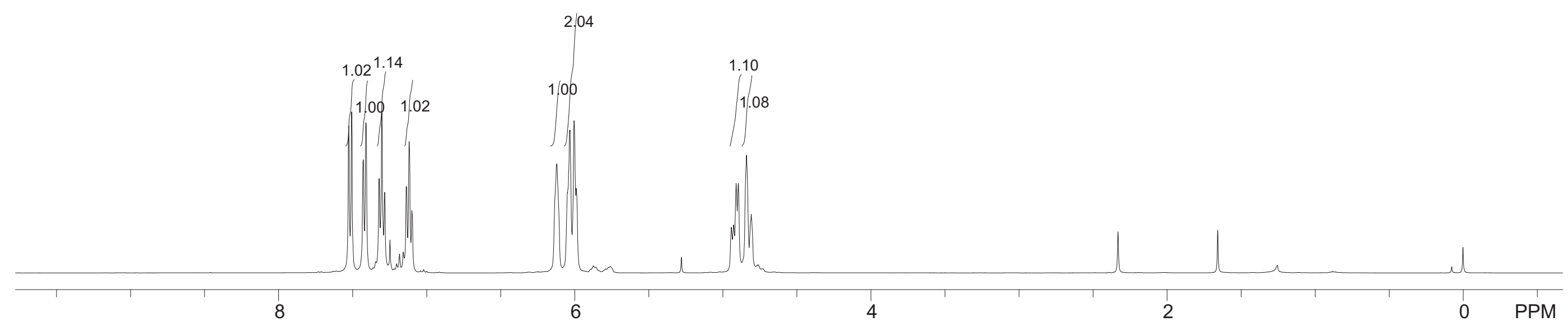




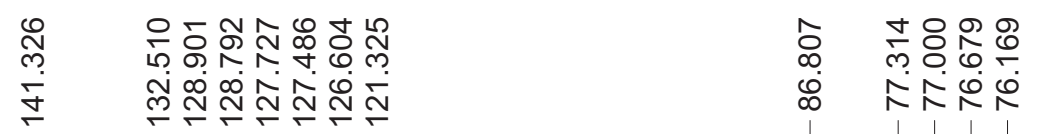

$\overbrace{\mathrm{Br}}$

3am

$\left(100 \mathrm{MHz}, \mathrm{CDCl}_{3}\right)$

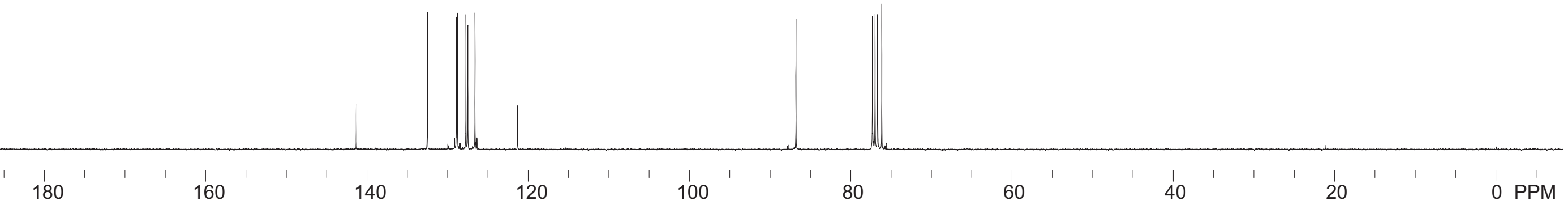



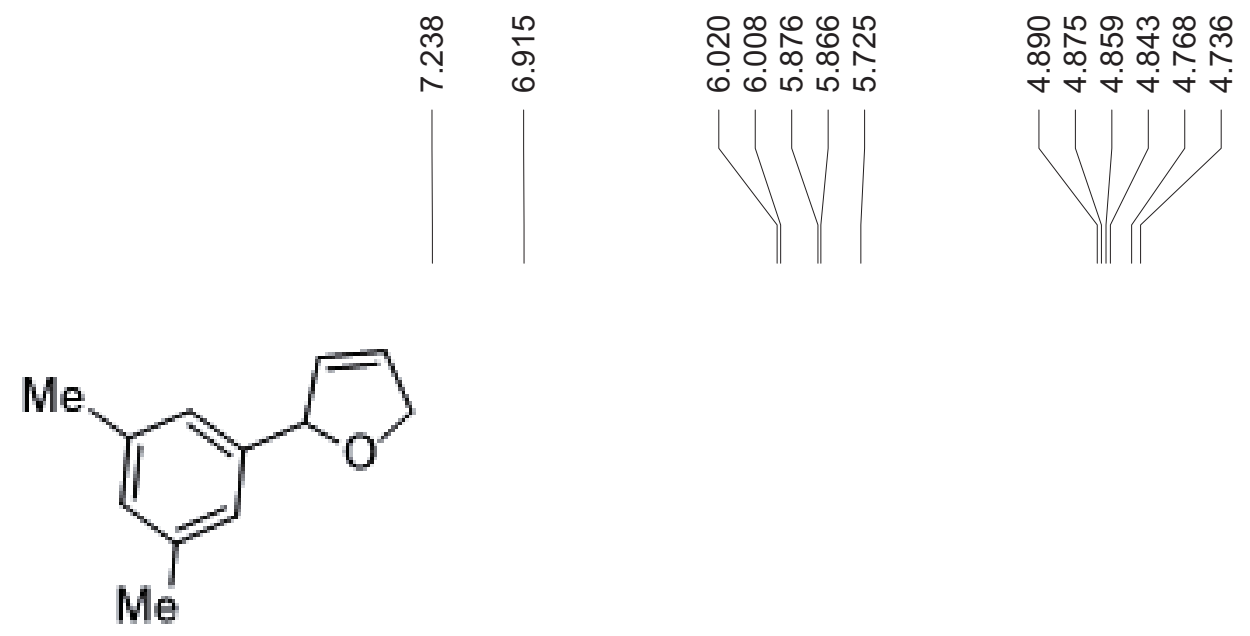

3an

(400 MHz, $\mathrm{CDCl}_{3}$ )

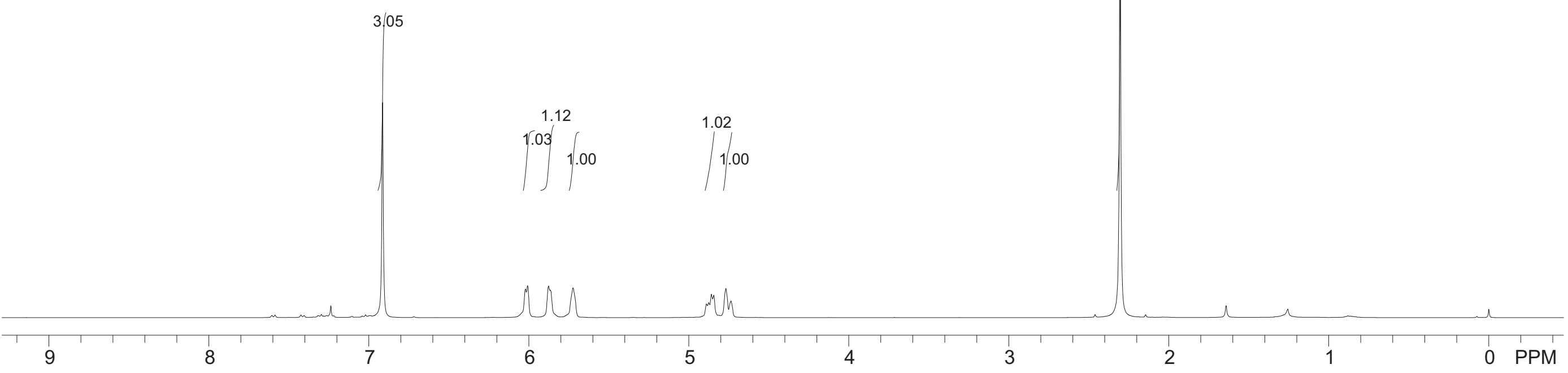




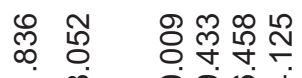

守

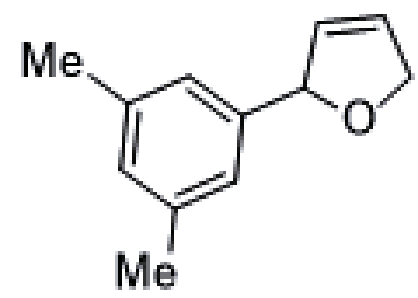

3an

(100 MHz, $\mathrm{CDCl}_{3}$ )

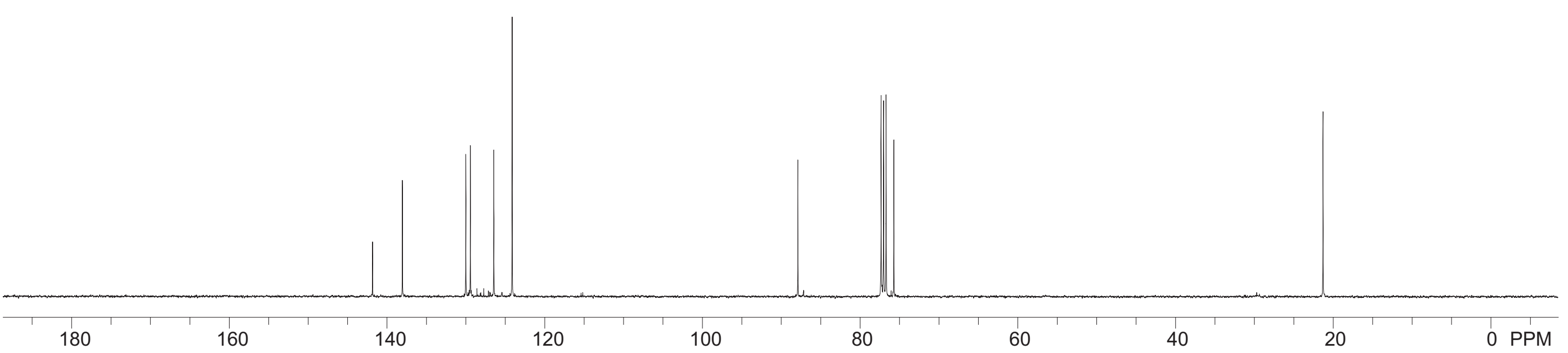


๙

ベNヘN采

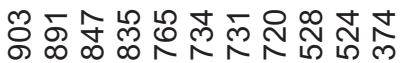<smiles>CC(=O)OC(=O)N1CC=CC1c1ccccc1</smiles>

\section{3 ba}

major 3 ba (rotamers ratio $=2.6: 1)$

$\left(400 \mathrm{MHz}, \mathrm{CDCl}_{3}\right)$

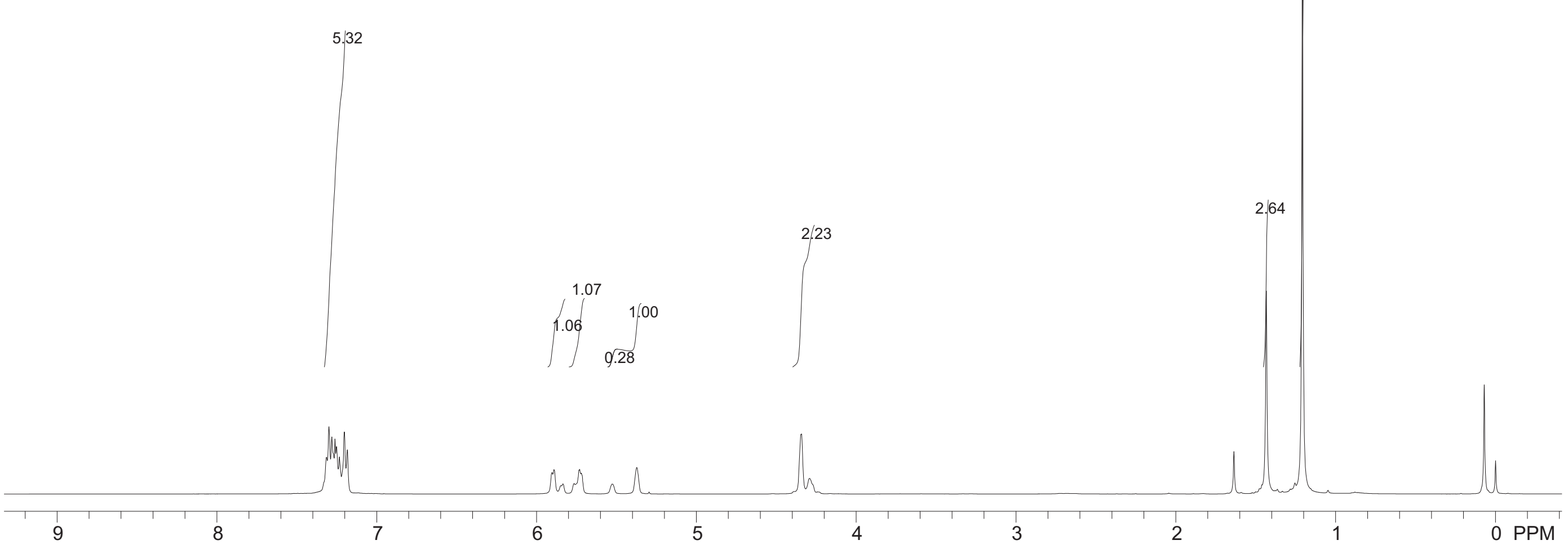


<smiles>CC(C)(C)OC(=O)N1CC=CC1c1ccccc1</smiles>

\section{3ba}

major 3 ba (rotamers ratio $=2.6: 1)$

$\left(100 \mathrm{MHz}, \mathrm{CDCl}_{3}\right.$ )

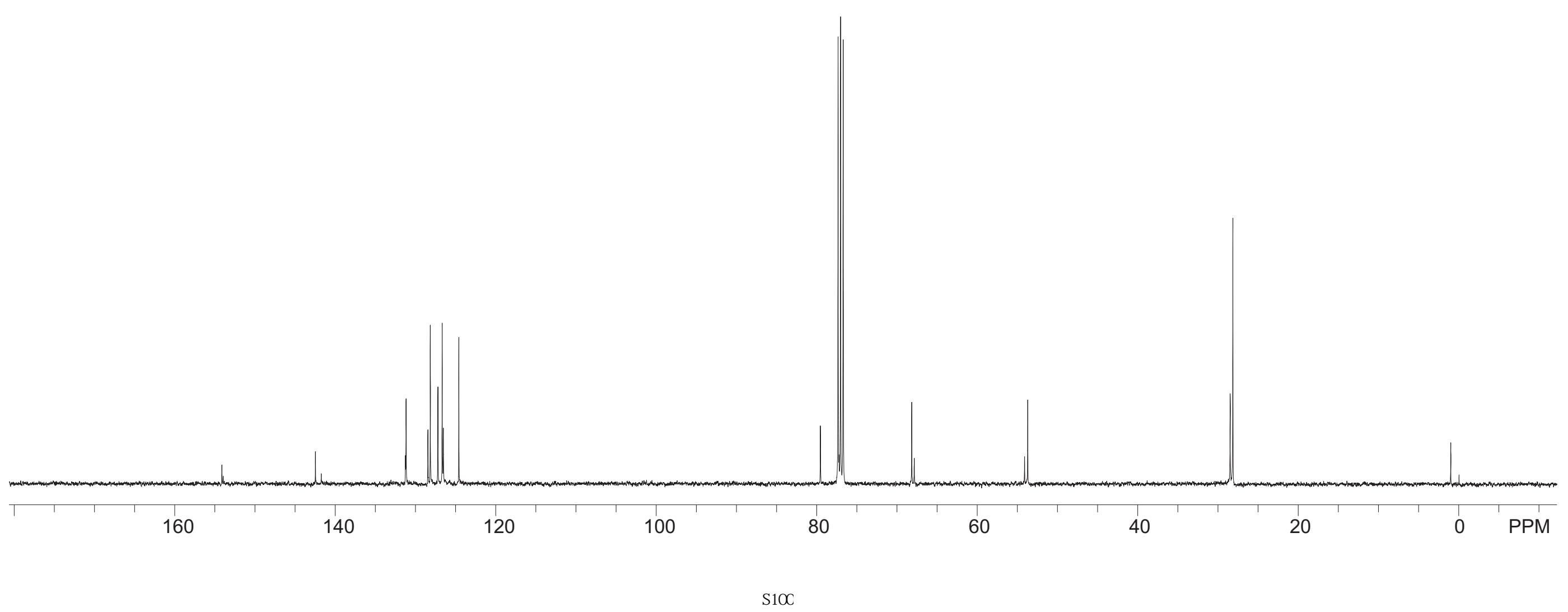




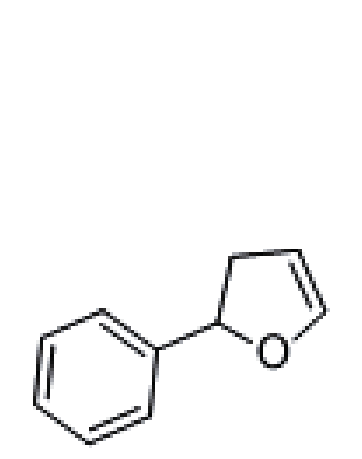

\section{4aa $\left(400 \mathrm{MHz} \mathrm{CDCl}_{3}\right)$}

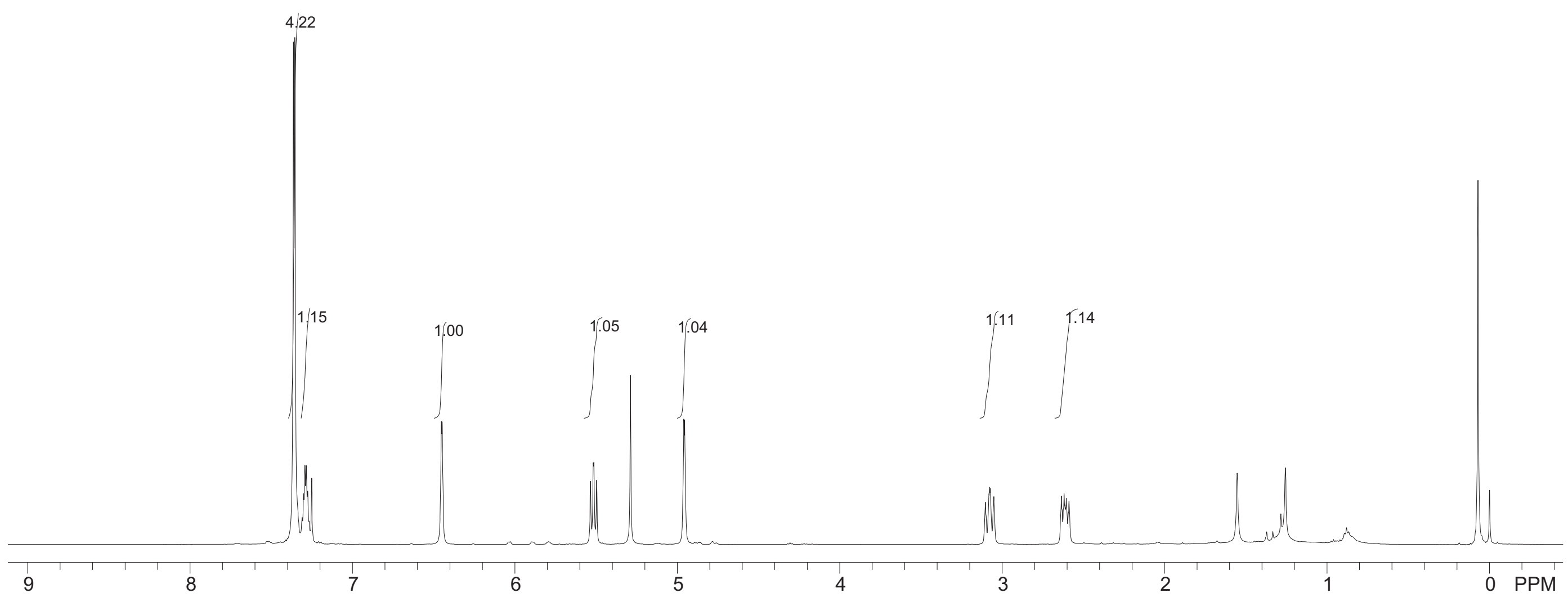




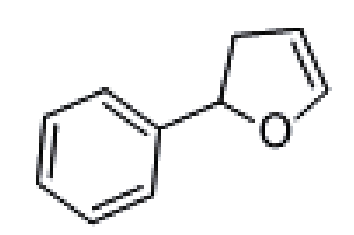

\section{4aa $\left(100 \mathrm{MHz} \mathrm{CDCl}_{3}\right)$}

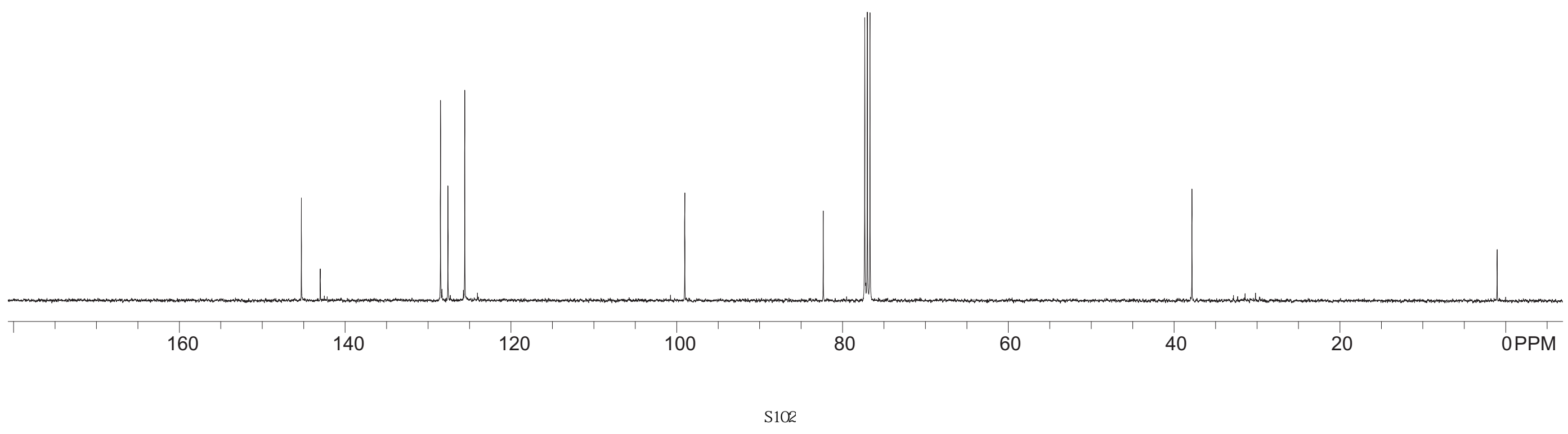




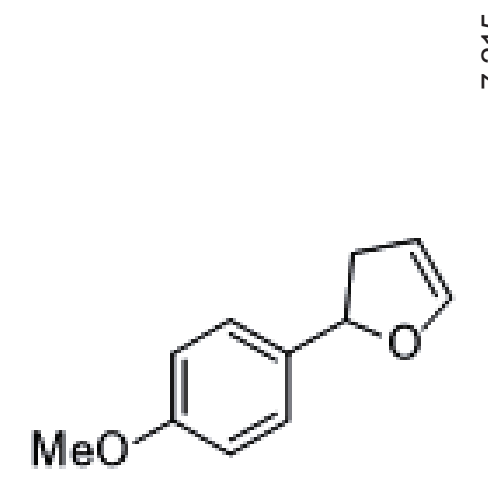

\section{4ab (400 MHz, $\left.\mathrm{CDCl}_{3}\right)$}

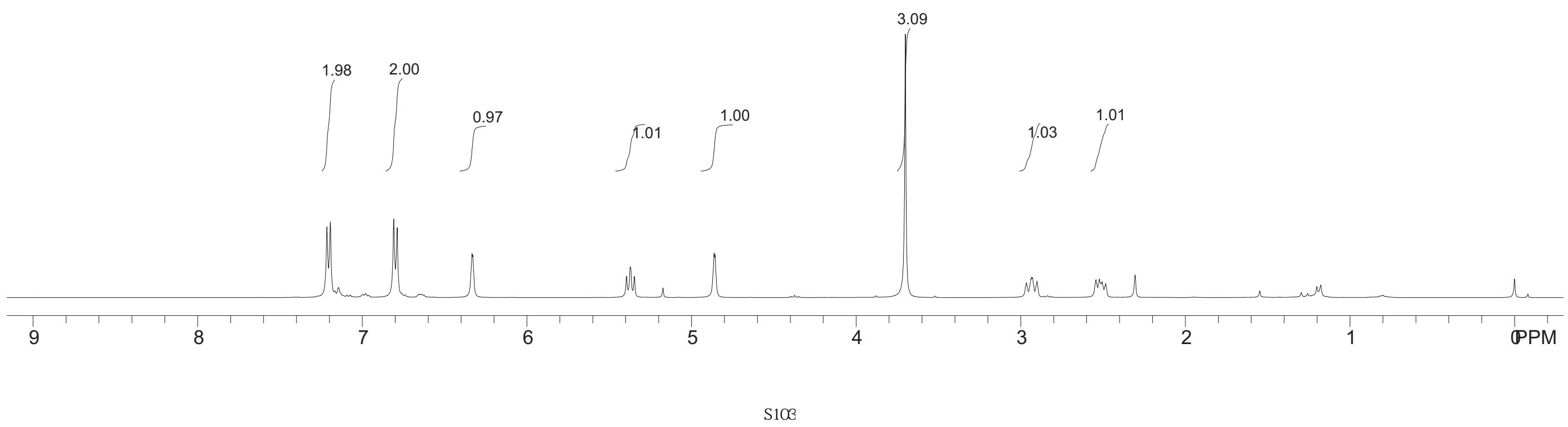




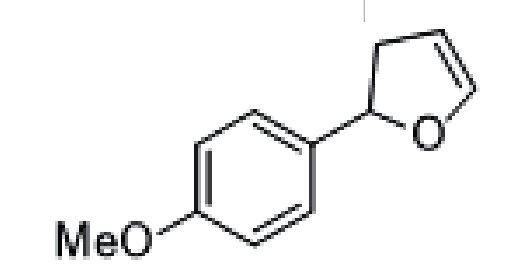

4ab (100 MHz, $\left.\mathrm{CDCl}_{3}\right)$

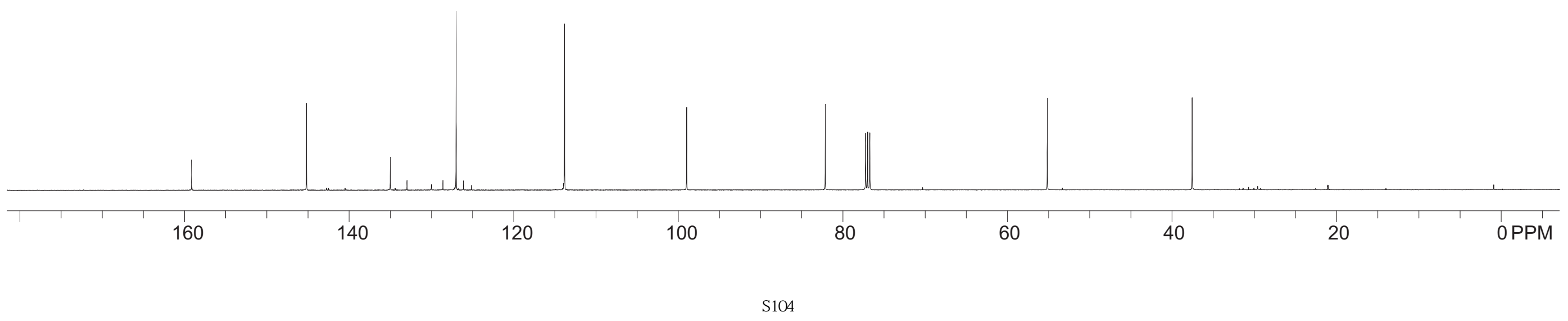




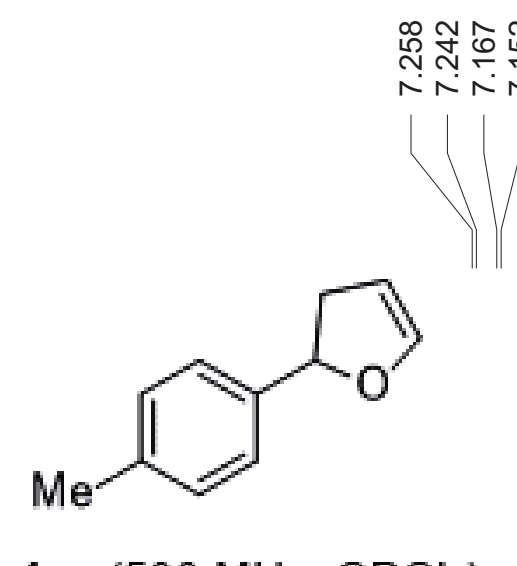

4ac $\left(500 \mathrm{MHz}, \mathrm{CDCl}_{3}\right)$

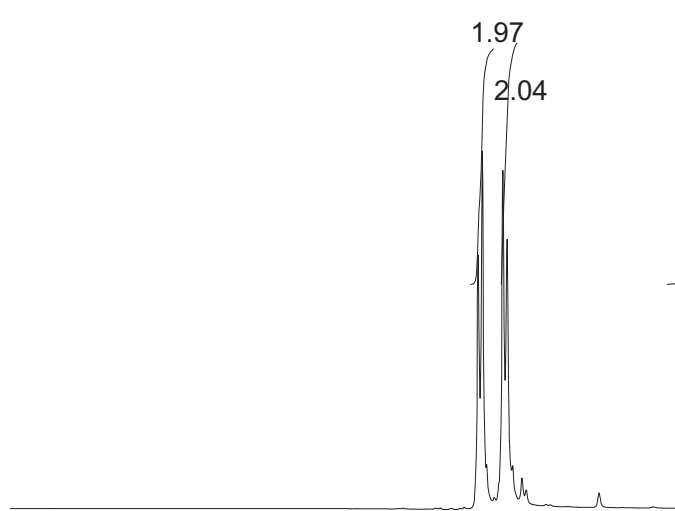

1.00

1.05 


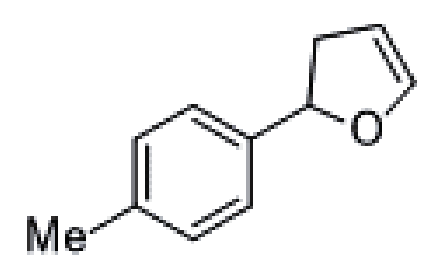

4ac $\left(125 \mathrm{MHz}_{1} \mathrm{CDCl}_{3}\right)$

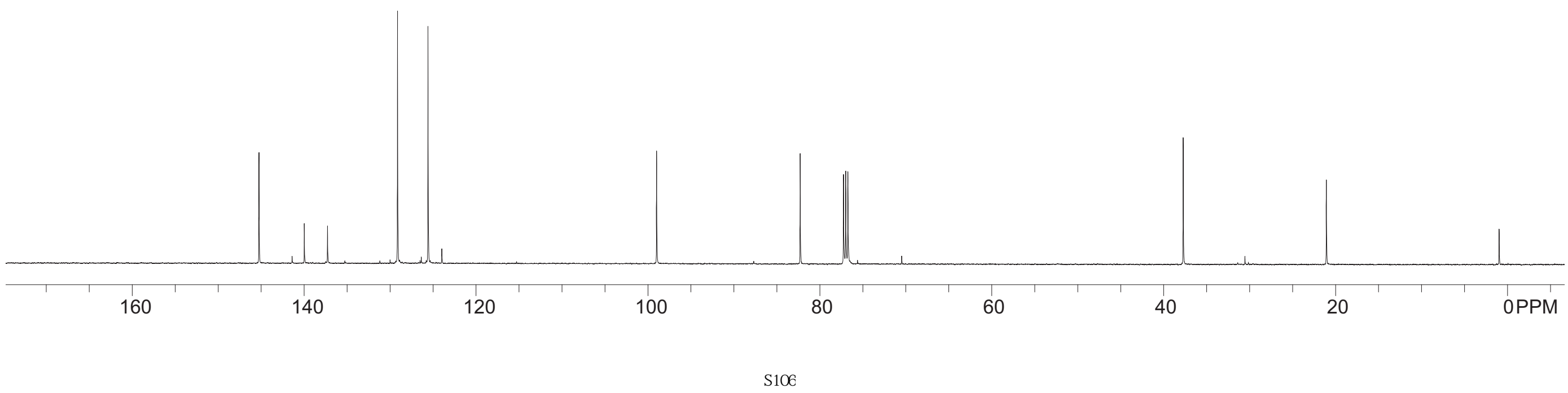




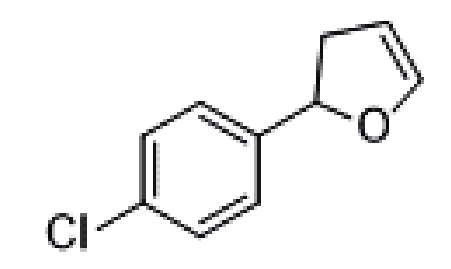

\section{4ad $\left(500 \mathrm{MHz}, \mathrm{CDCl}_{3}\right)$}

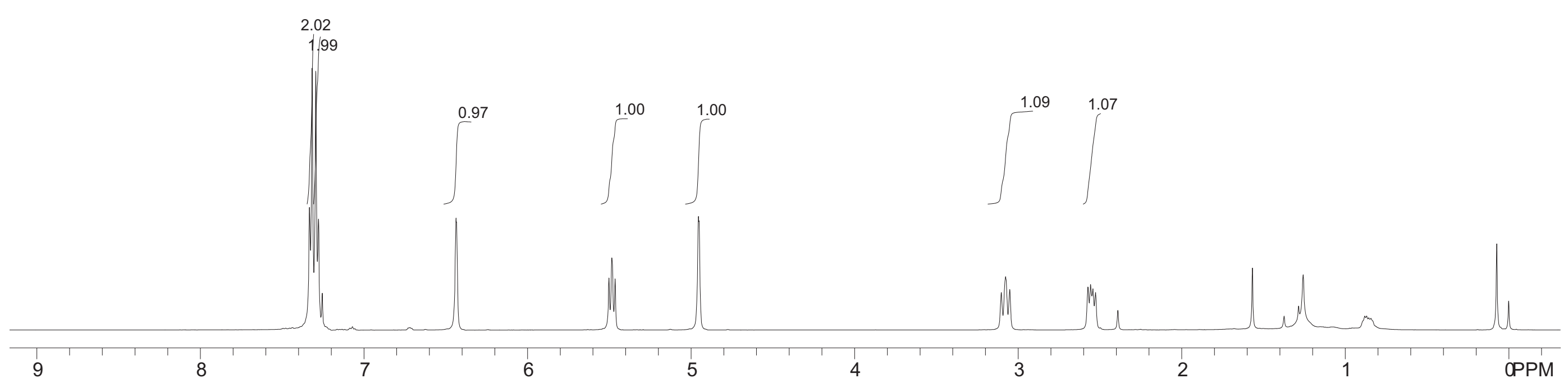


怘品 总 守志

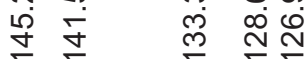

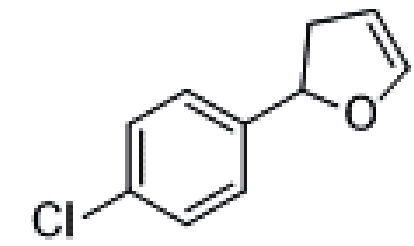

4ad (125 MHz, $\left.\mathrm{CDCl}_{3}\right)$

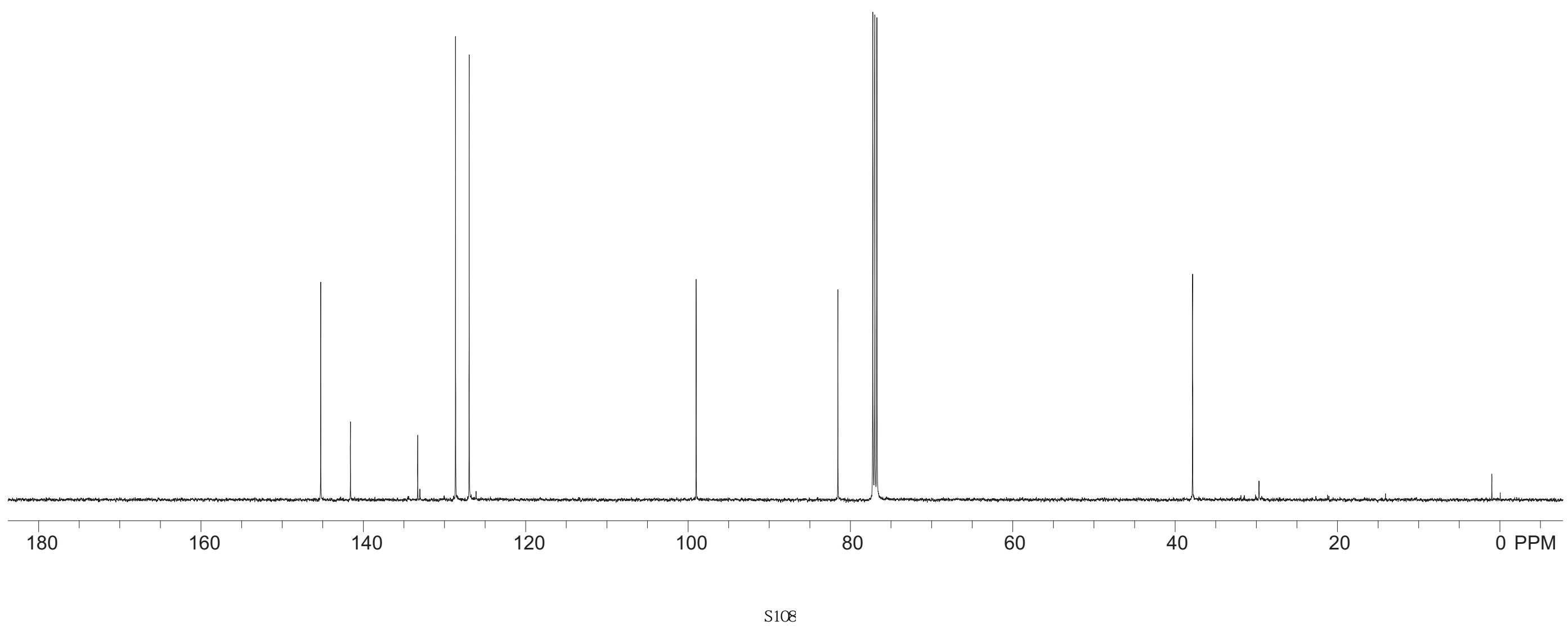




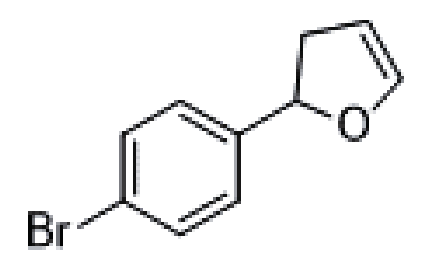

\section{4ae $\left(400 \mathrm{MHz}_{1} \mathrm{CDCl}_{3}\right)$}

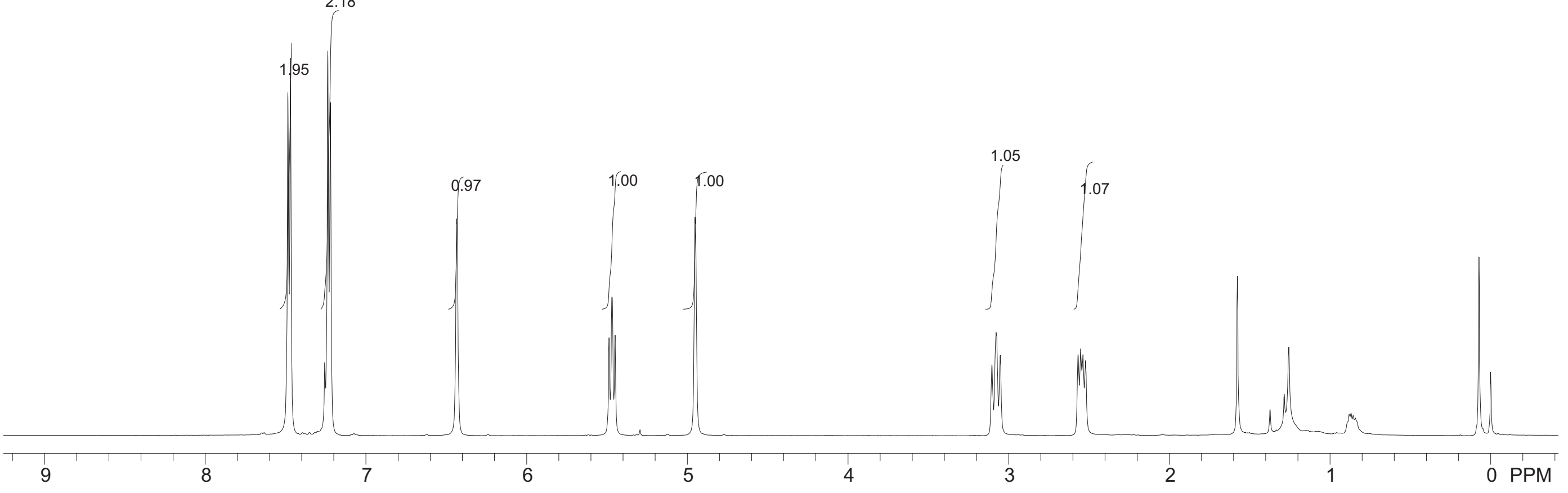


동

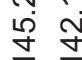

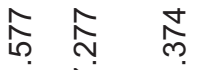

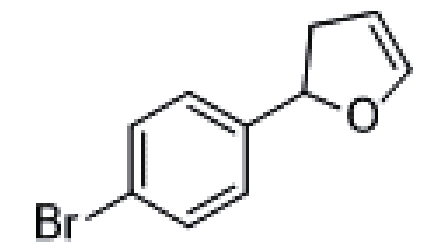

4ae $\left(100 \mathrm{MHz} \mathrm{CDCl}_{3}\right)$

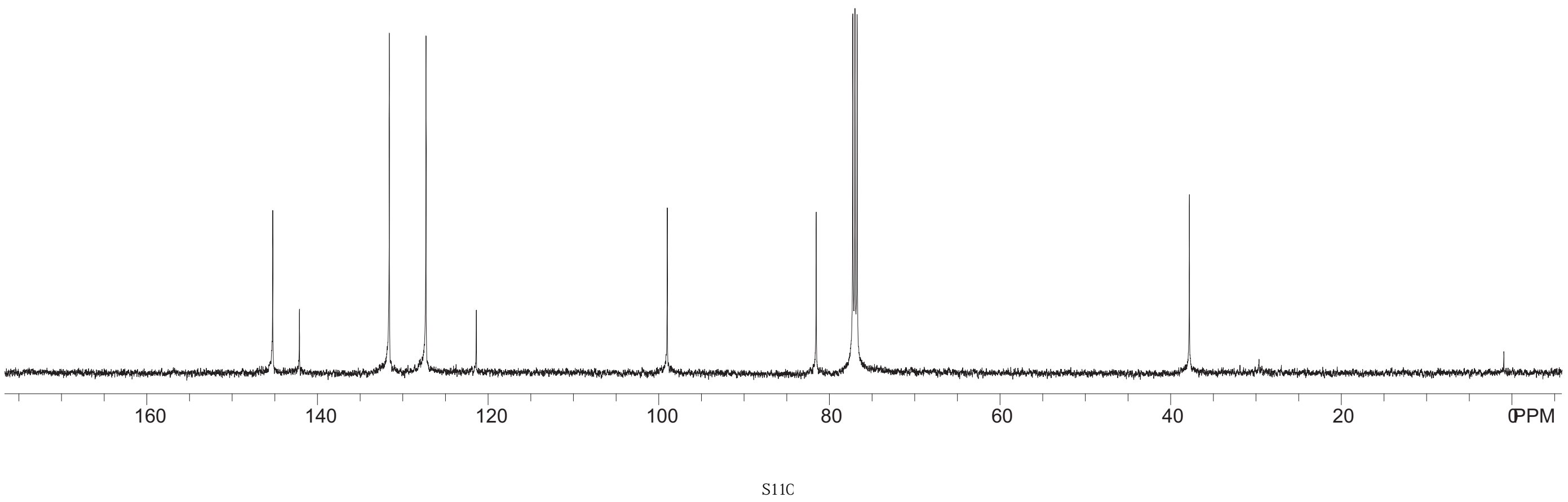




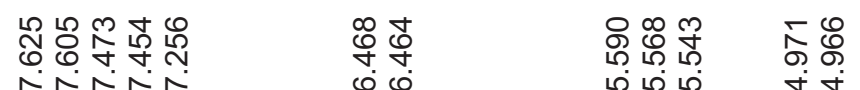

$\checkmark \forall$

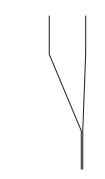

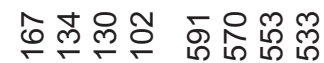

लं山 m户

108
50
0

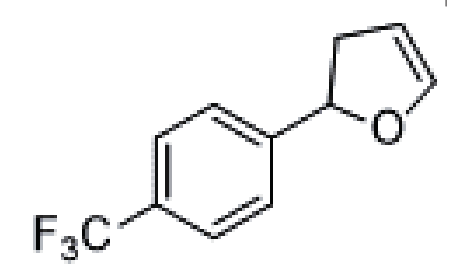

4af $\left(400 \mathrm{MHz}, \mathrm{CDCl}_{3}\right)$

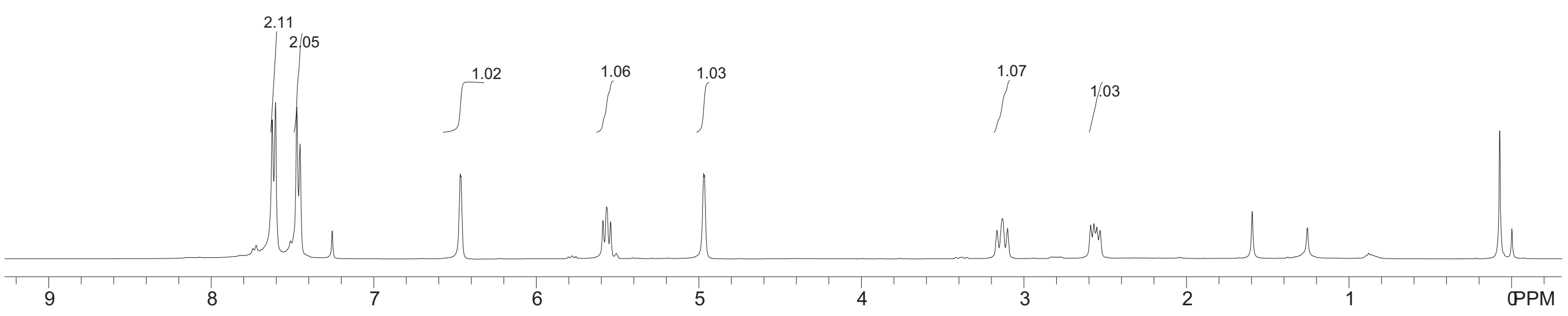




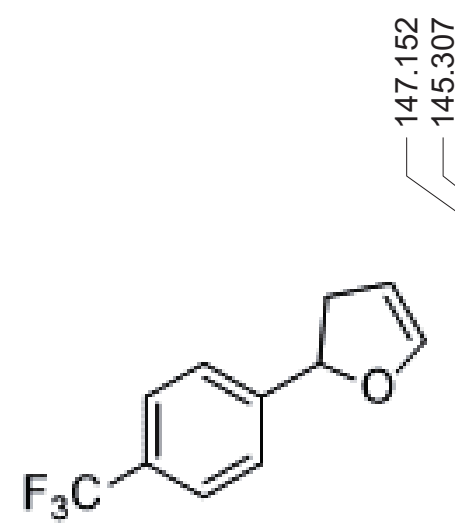

4af $\left(100 \mathrm{MHz}, \mathrm{CDCl}_{3}\right)$

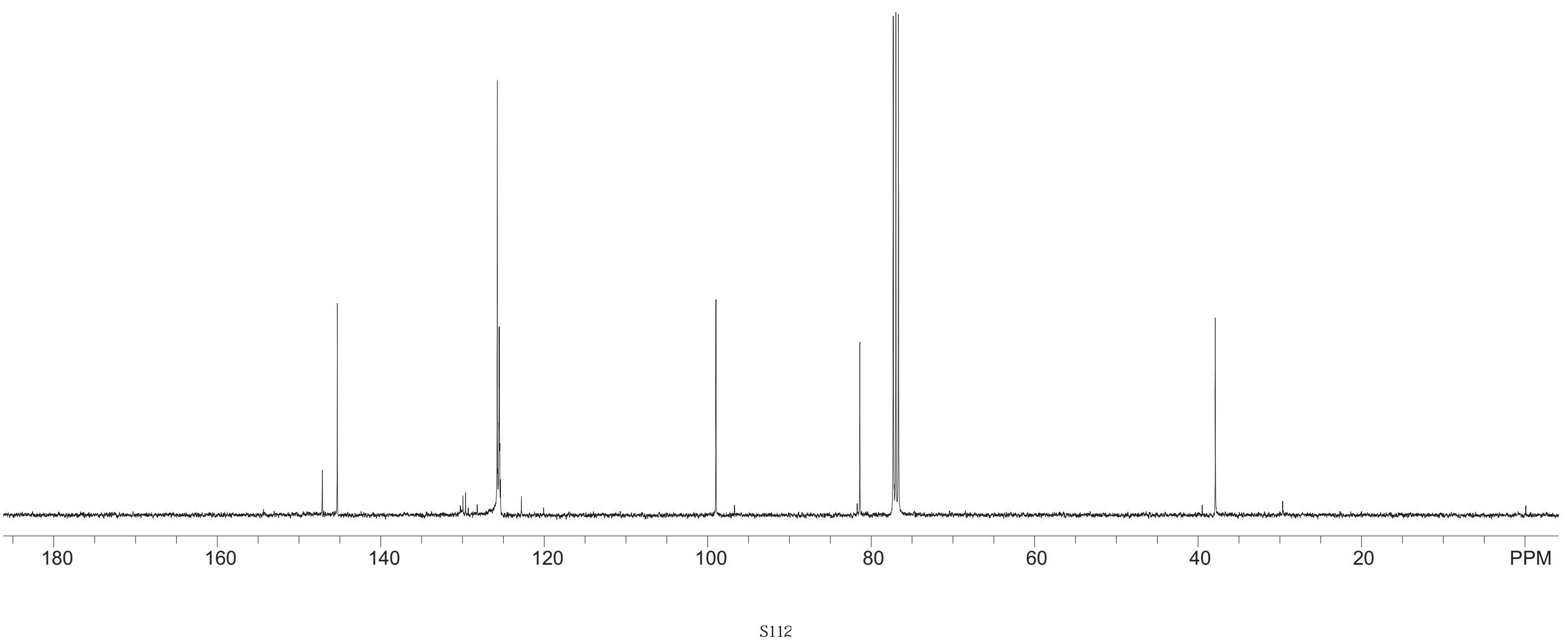




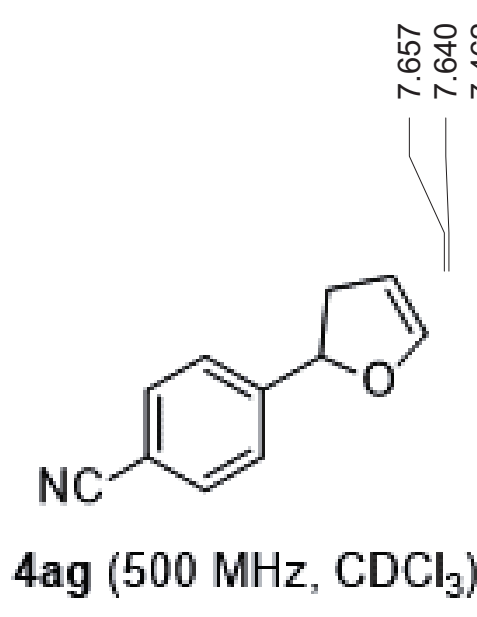

4ag (500 MHz, $\left.\mathrm{CDCl}_{3}\right)$

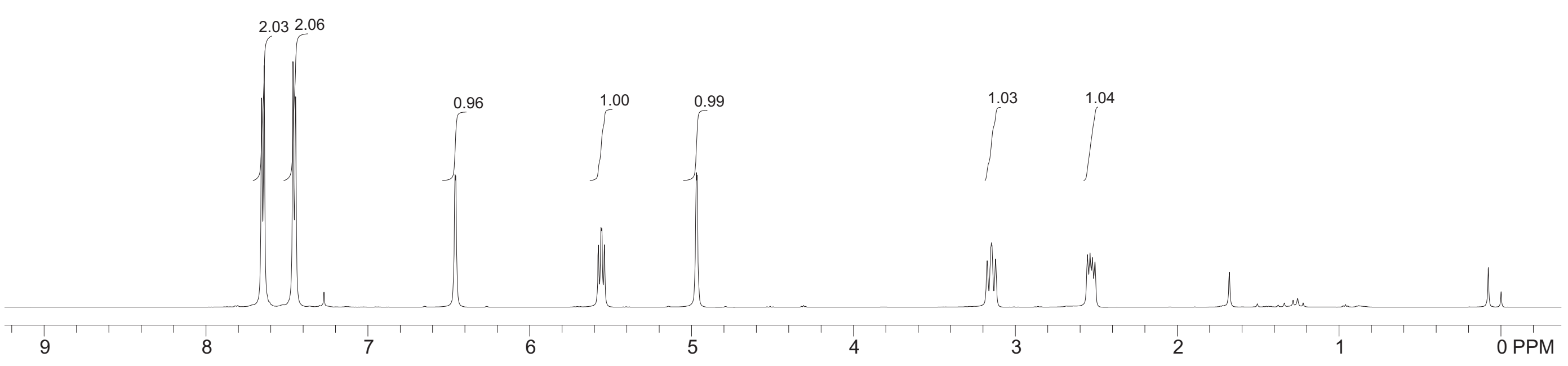




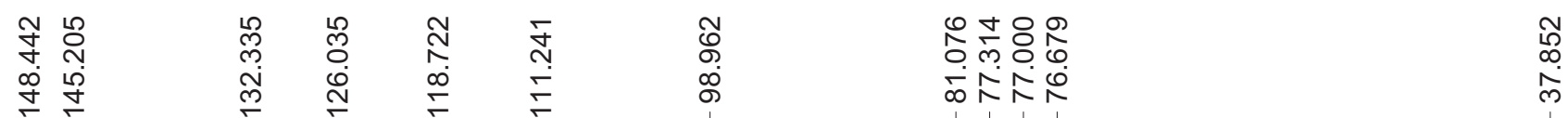

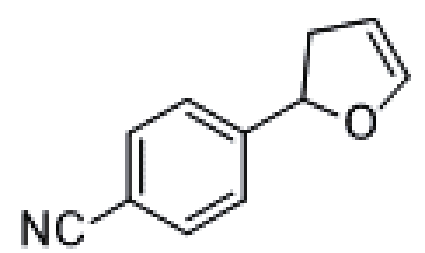

4ag (100 MHz, $\left.\mathrm{CDCl}_{3}\right)$

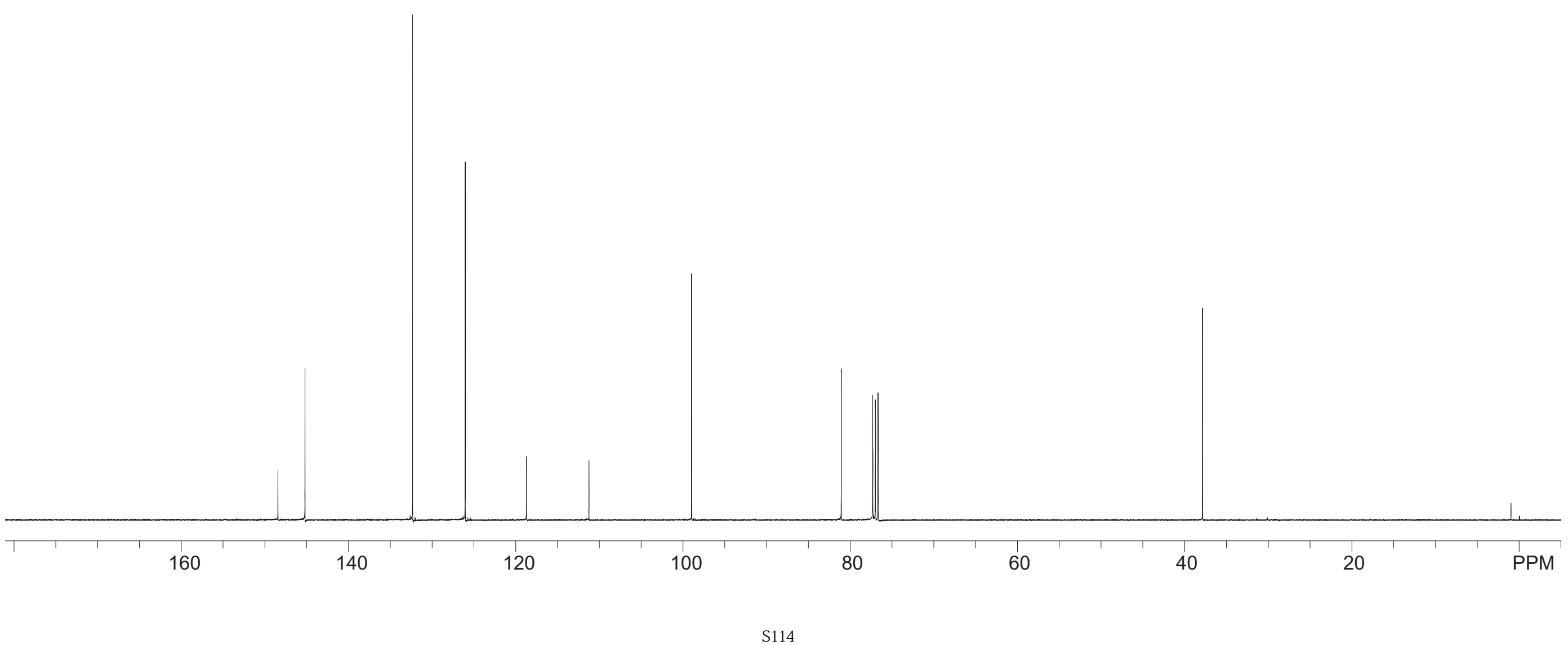




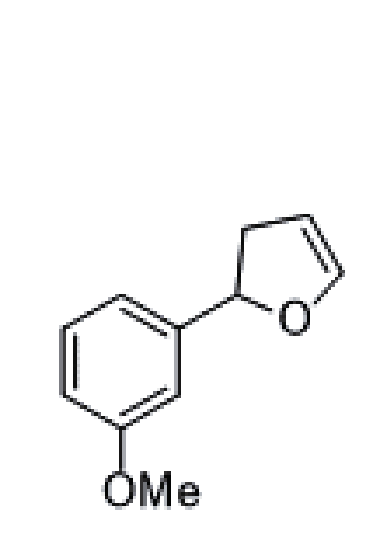

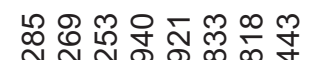

กิ กุ

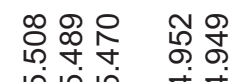

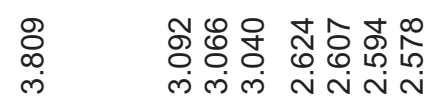

4ah $\left(500 \mathrm{MHz}, \mathrm{CDCl}_{3}\right)$

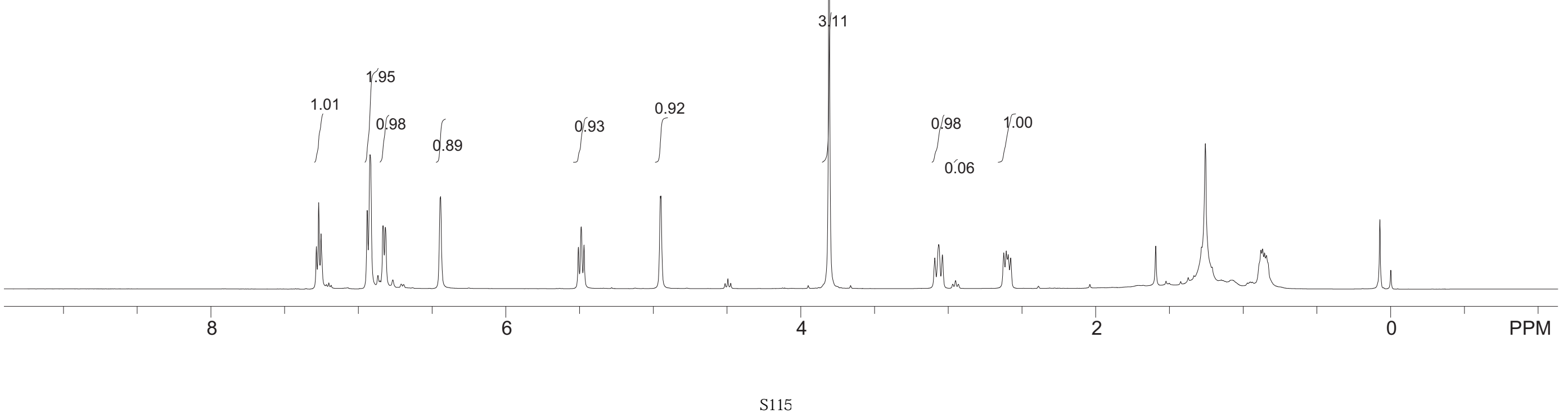




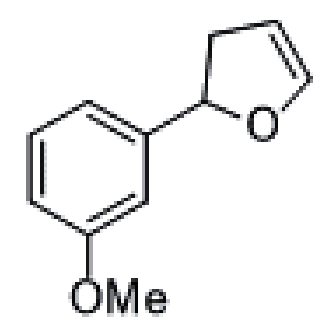

4ah (125 MHz, $\mathrm{CDCl}_{3}$ )

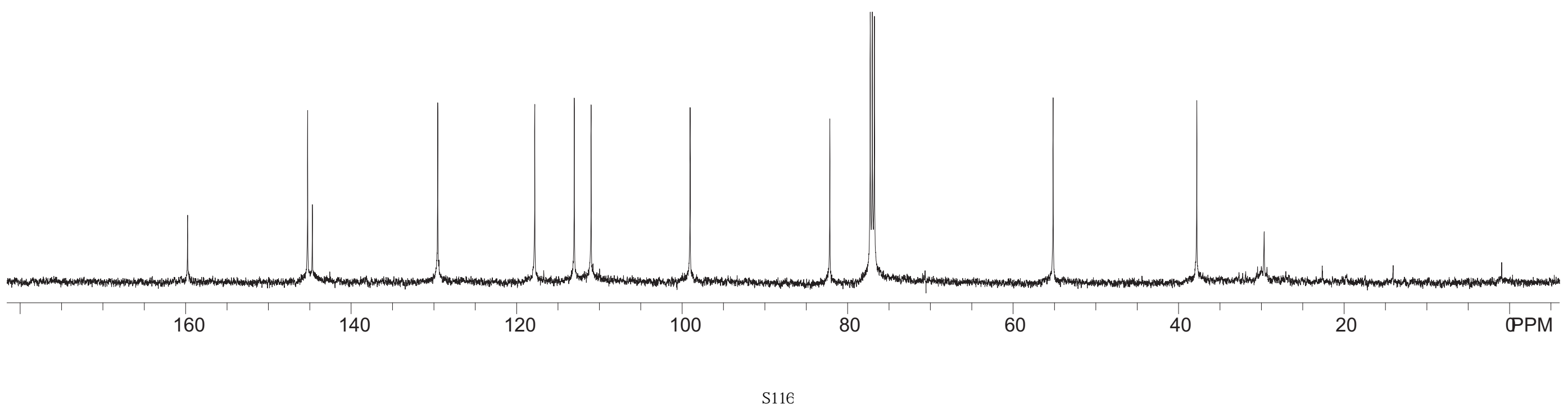




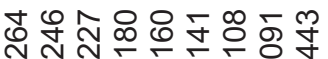

NNNベNヘ。

웅용

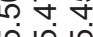
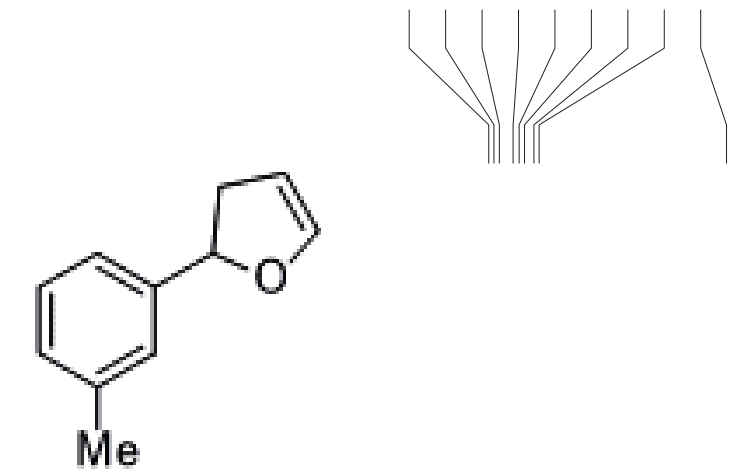

\section{4ai (400 MHz, $\left.\mathrm{CDCl}_{3}\right)$}

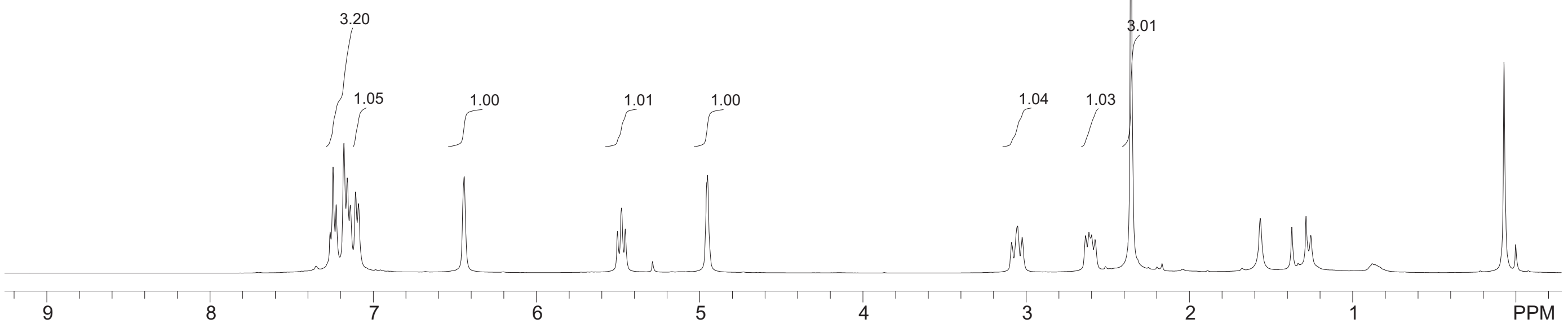




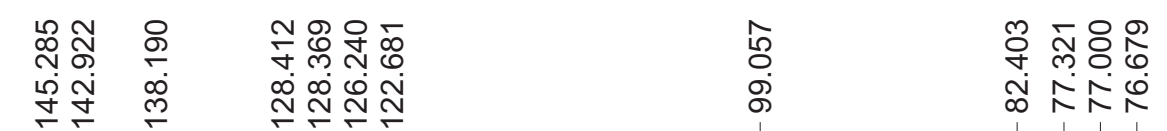

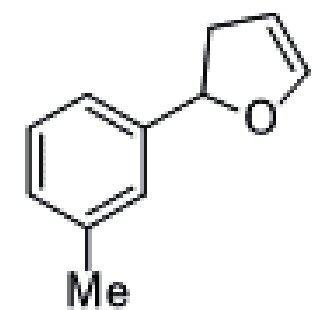

4ai $\left(100 \mathrm{MHz} \mathrm{CDCl}_{3}\right)$

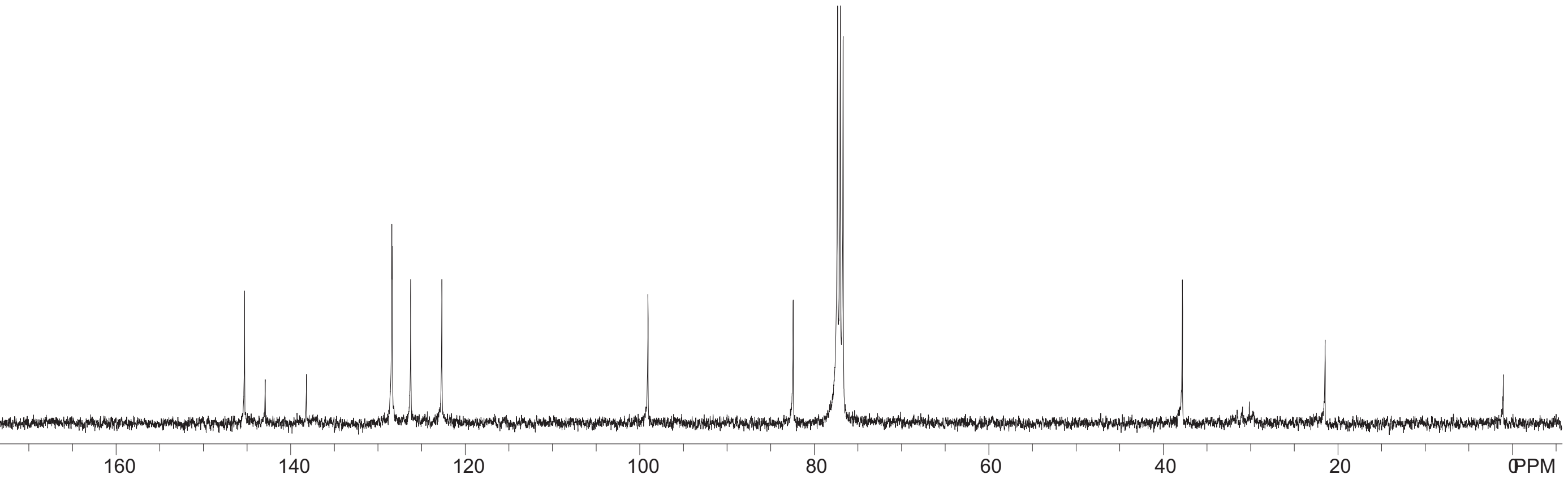




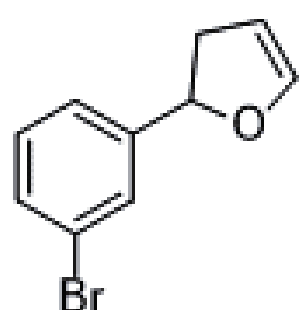

4aj (500 MHz, $\mathrm{CDCl}_{3}$ )

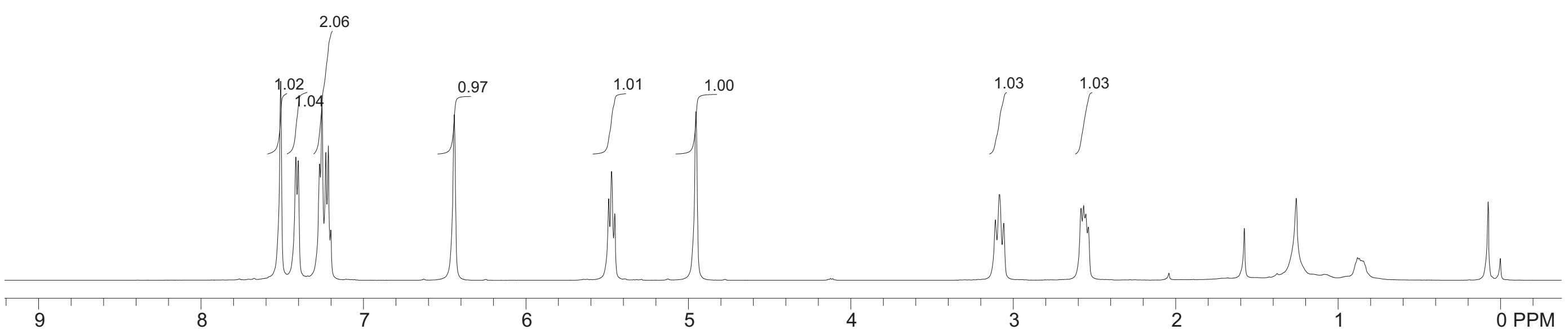




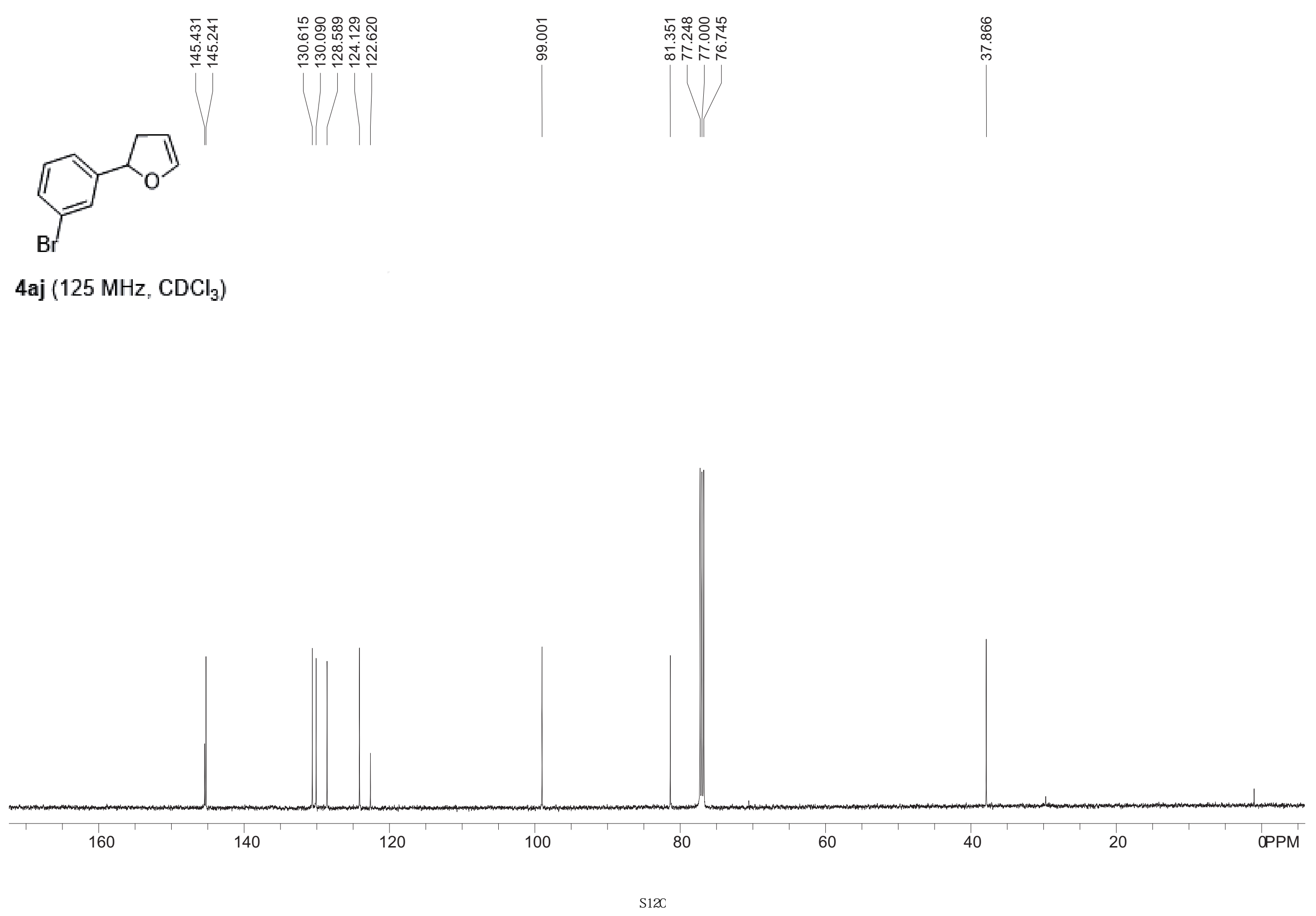



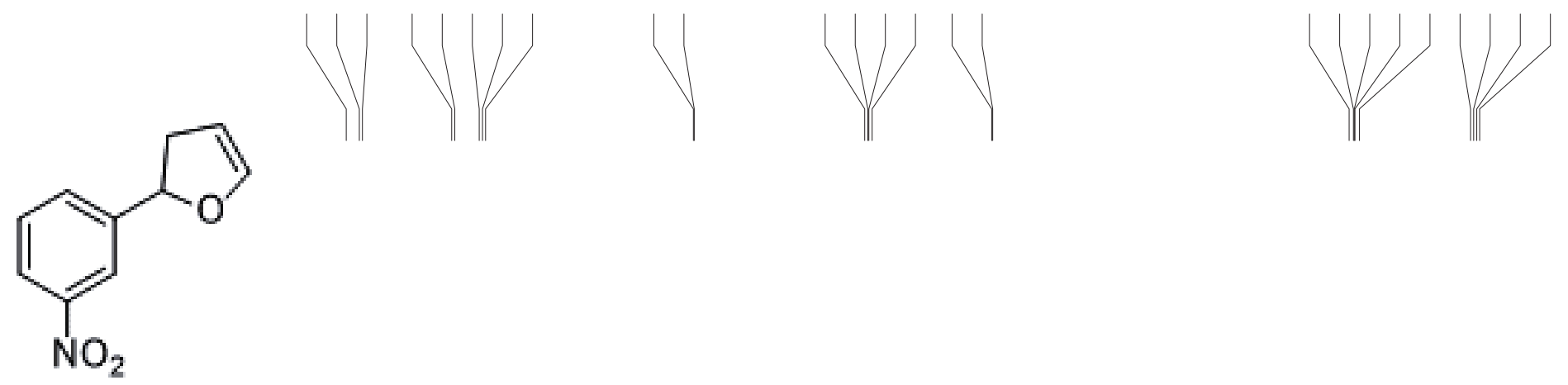

4ak $\left(500 \mathrm{MHz}, \mathrm{CDCl}_{3}\right)$

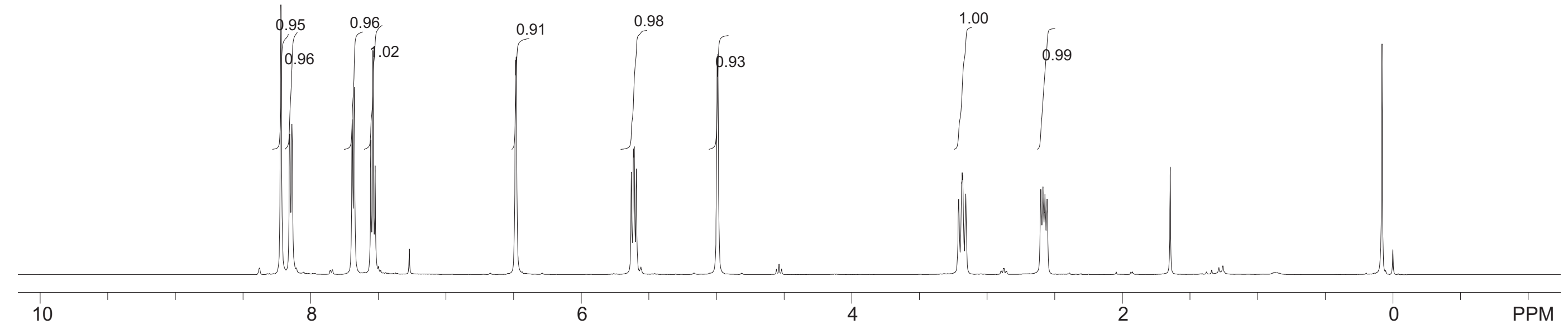




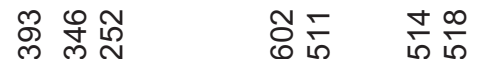

过过过 商过

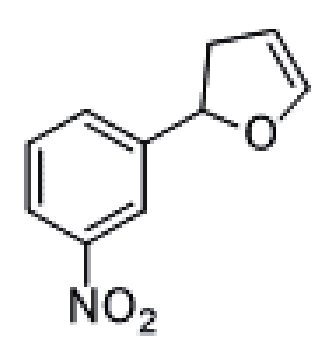

4ak (125 MHz, $\mathrm{CDCl}_{3}$ )

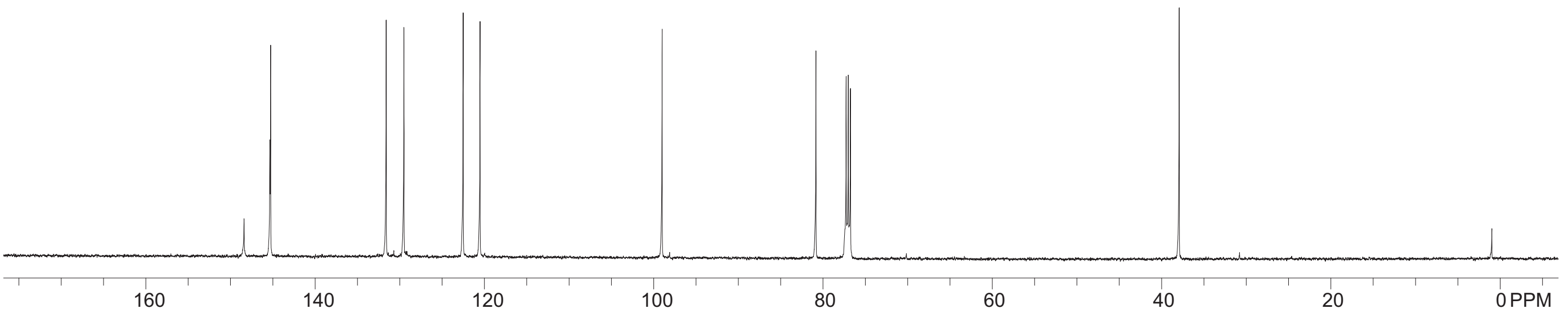




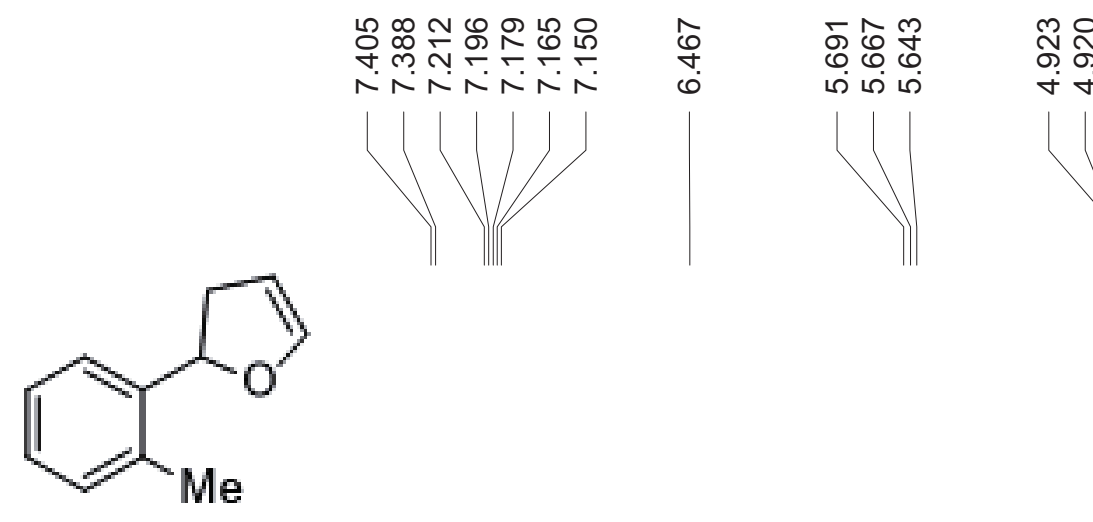

\section{4al (400 MHz, $\left.\mathrm{CDCl}_{3}\right)$}

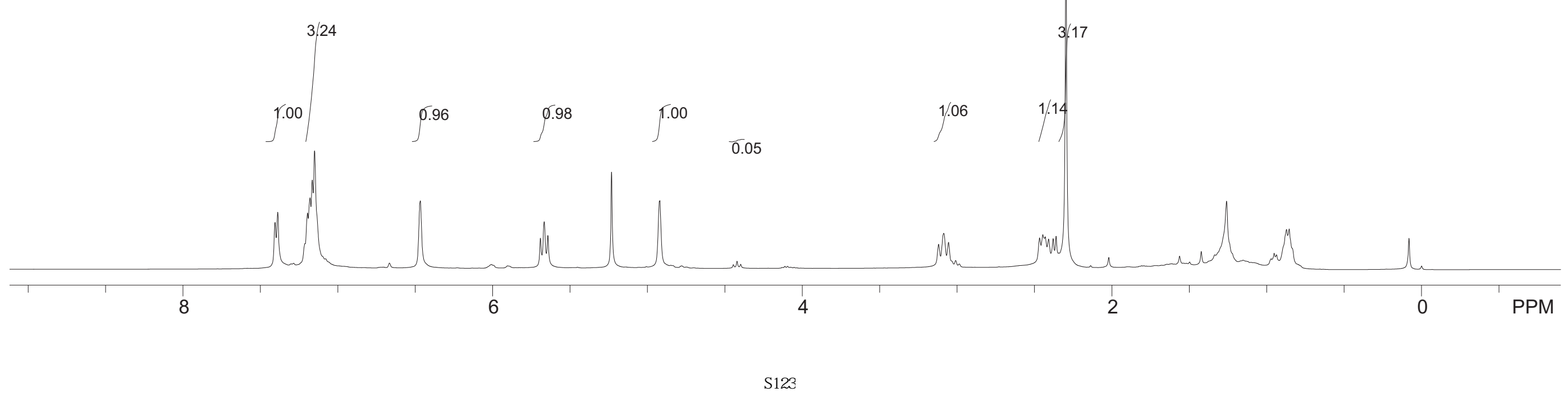


<smiles>Cc1ccccc1C1CC=CO1</smiles>

4al (100 MHz, $\left.\mathrm{CDCl}_{3}\right)$

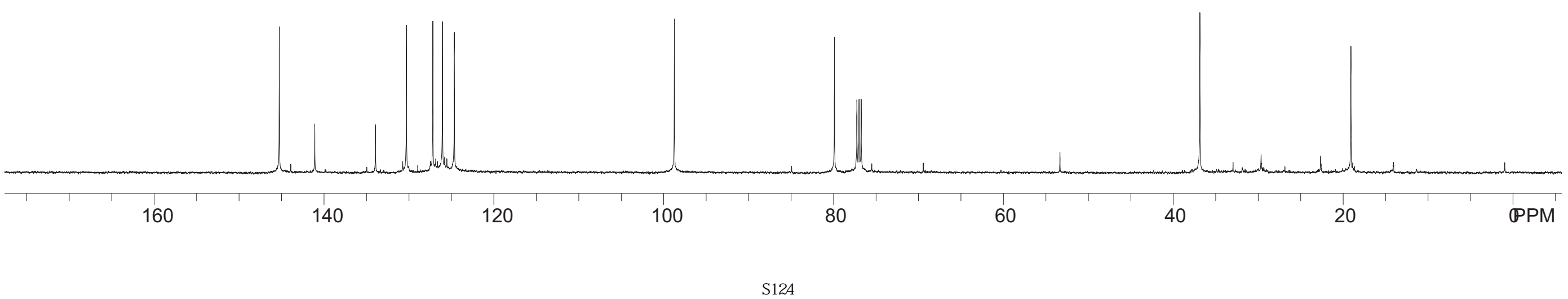


<smiles>Brc1ccccc1C1CC=CO1</smiles>

4am $\left(400 \mathrm{MHz}, \mathrm{CDCl}_{3}\right)$

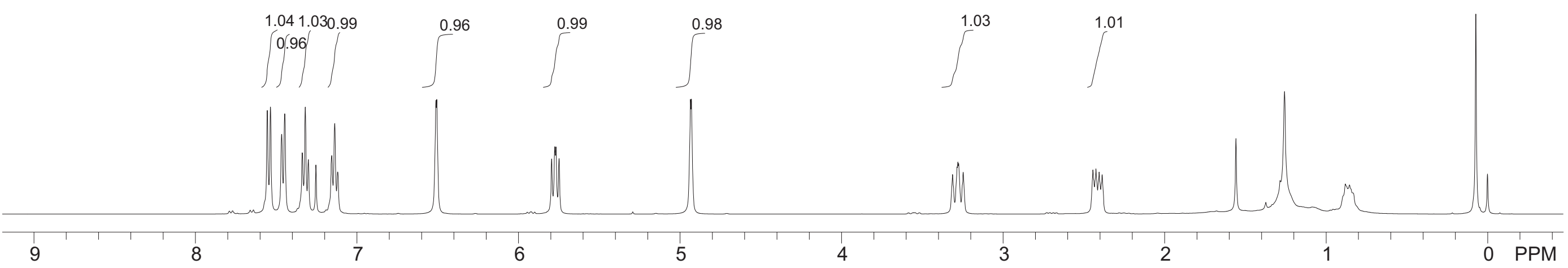




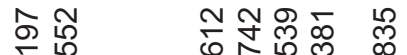

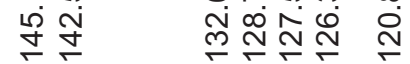

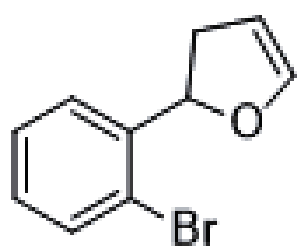

4am $\left(100 \mathrm{MHz}, \mathrm{CDCl}_{3}\right)$

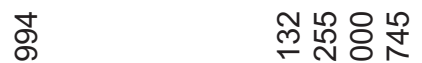

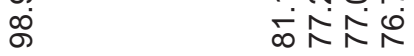

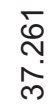

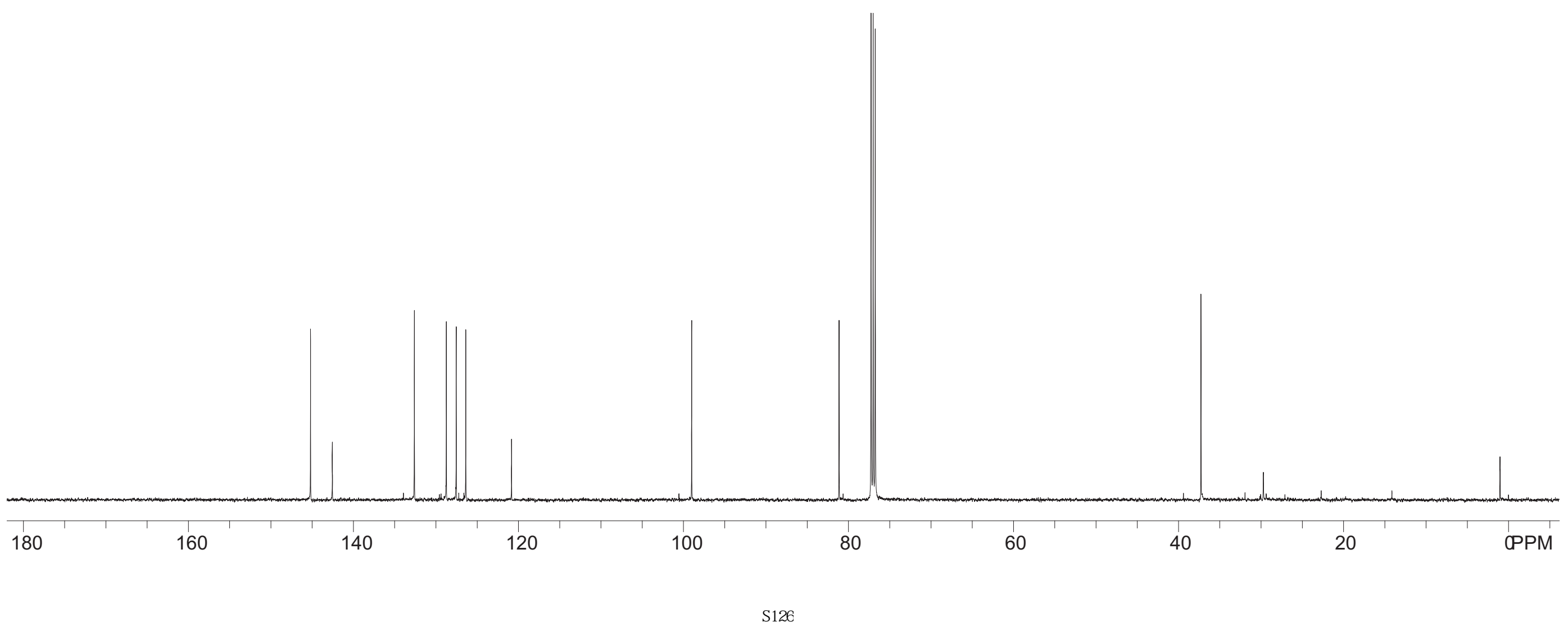




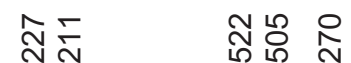

นก ก

$N N$

$\underset{\substack{\infty \\ 0}}{0}$

可苍葛

$\stackrel{\infty}{\infty}$

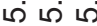

సิํำ

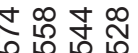

กิن

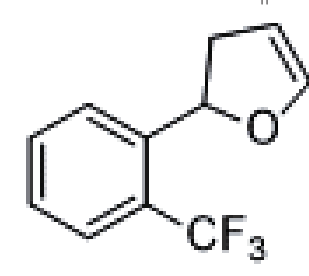

4an $\left(400 \mathrm{MHz}, \mathrm{CDCl}_{3}\right)$

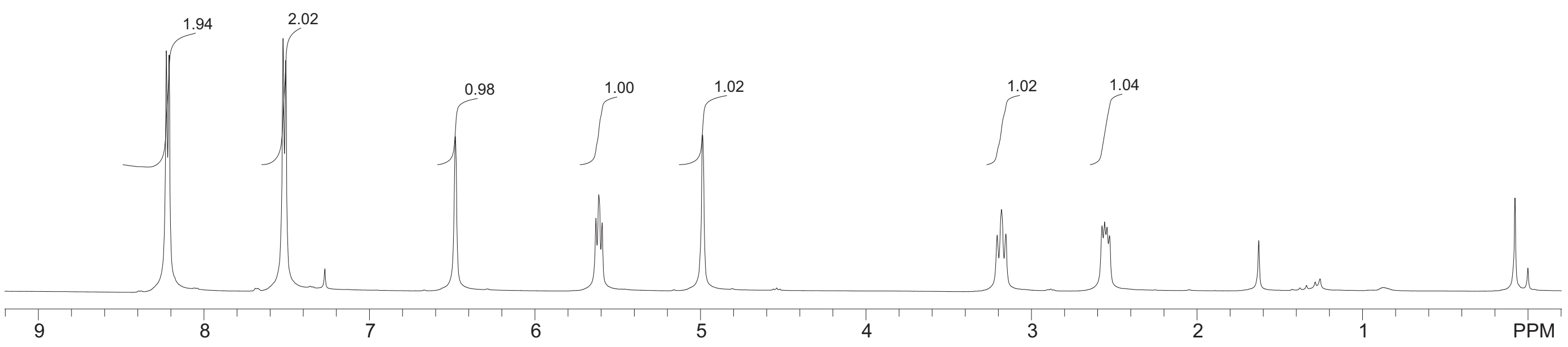


京忿命

号守

$: 0$

ํํำ

్ָ

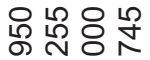

क수은

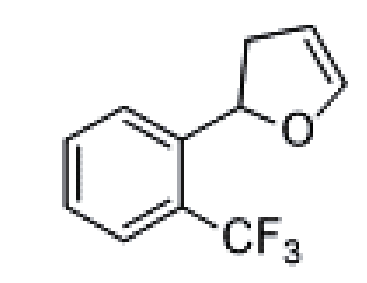

\section{4an $\left(100 \mathrm{MHz}, \mathrm{CDCl}_{3}\right)$}

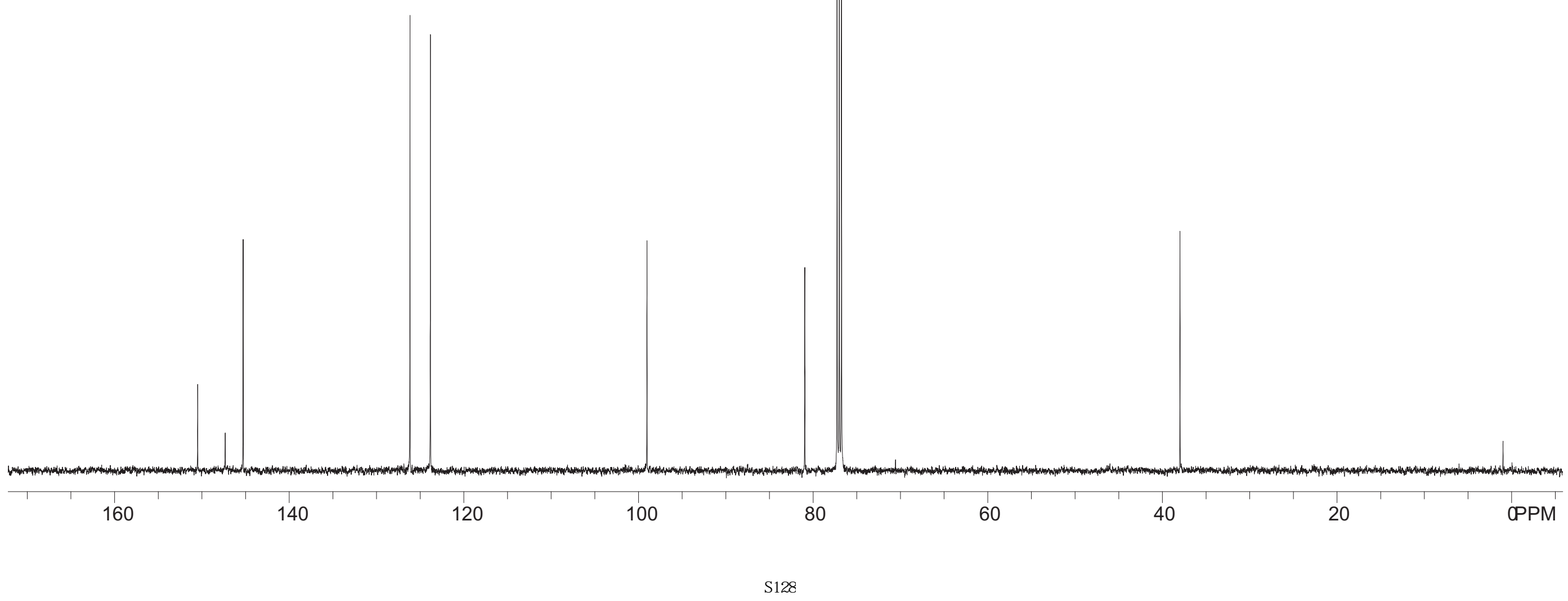




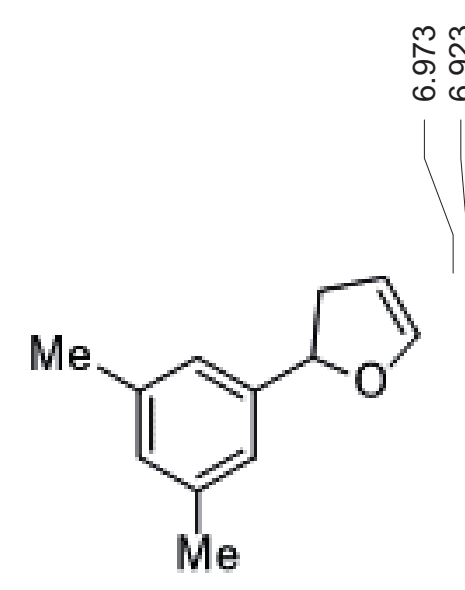

4ao $\left(500 \mathrm{MHz}, \mathrm{CDCl}_{3}\right)$

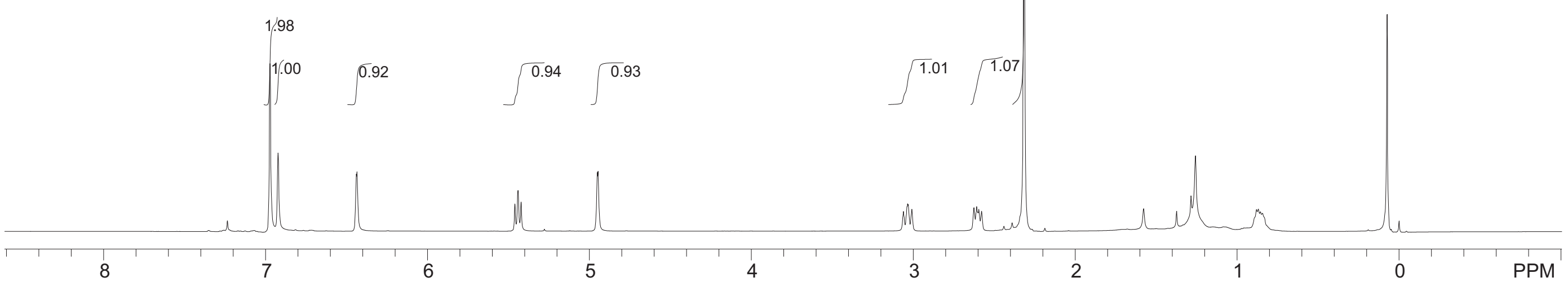




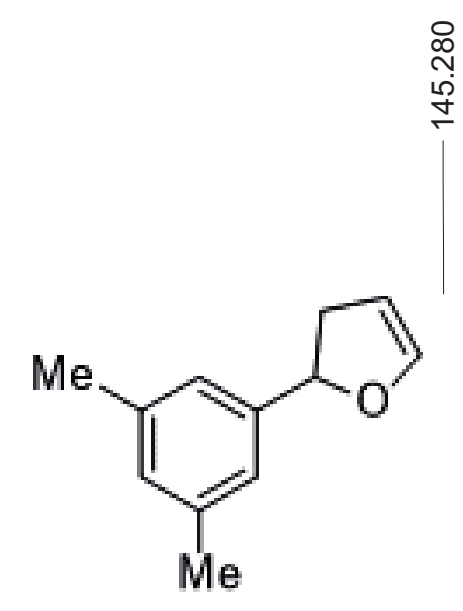

4ao $\left(100 \mathrm{MHz}, \mathrm{CDCl}_{3}\right)$

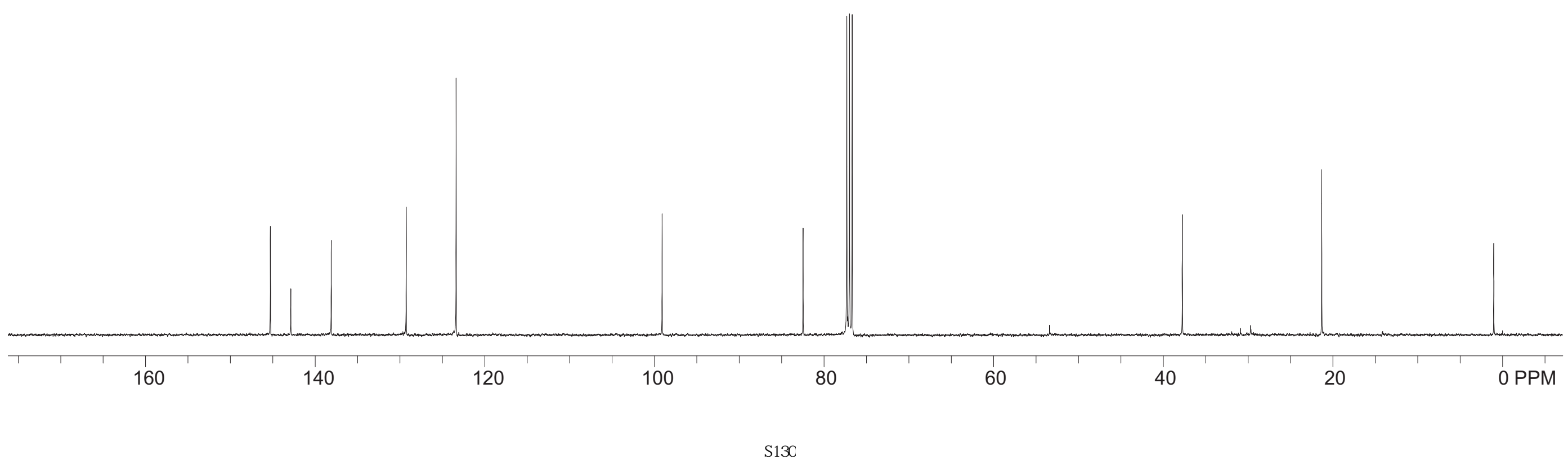


<smiles>FC(F)(F)c1cc(C2CC=CO2)cc(C(F)(F)F)c1</smiles>

4ap (400 MHz, $\mathrm{CDCl}_{3}$ )

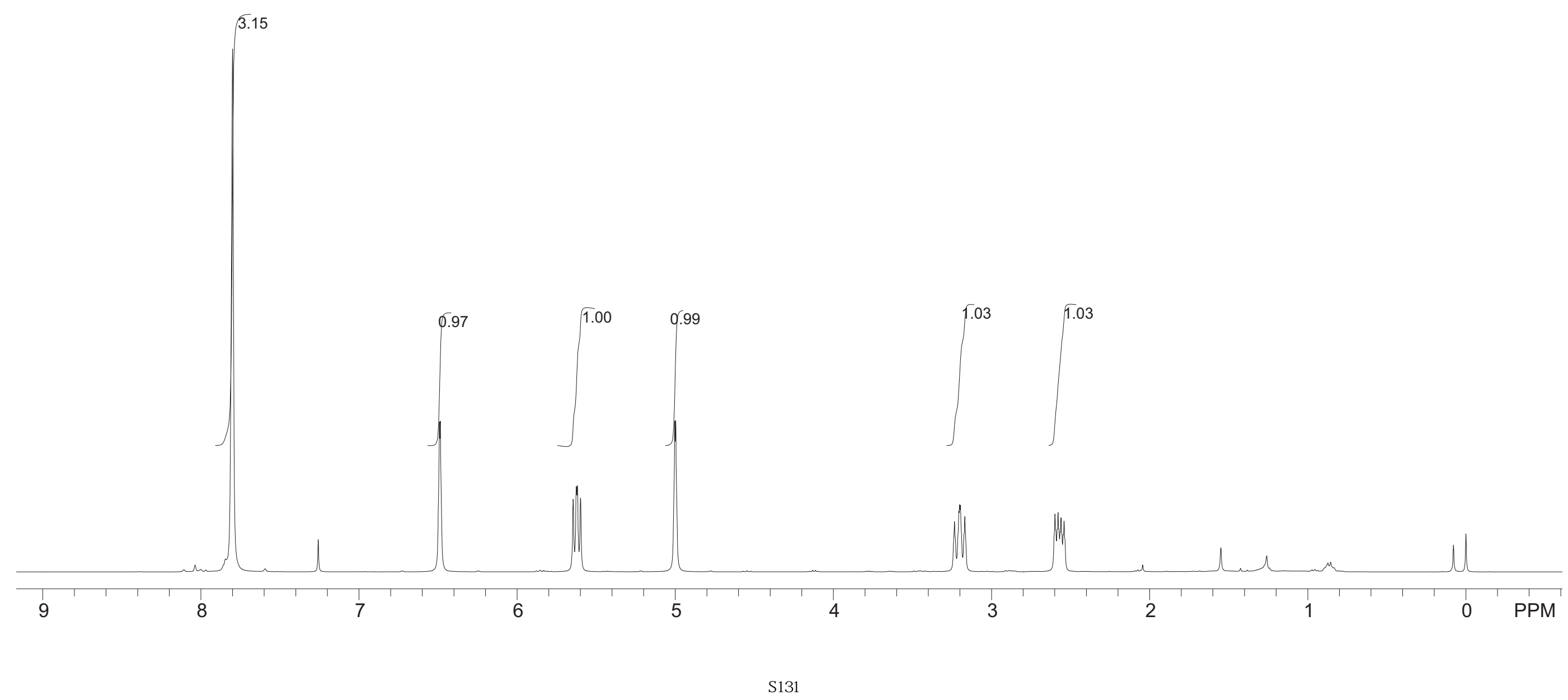




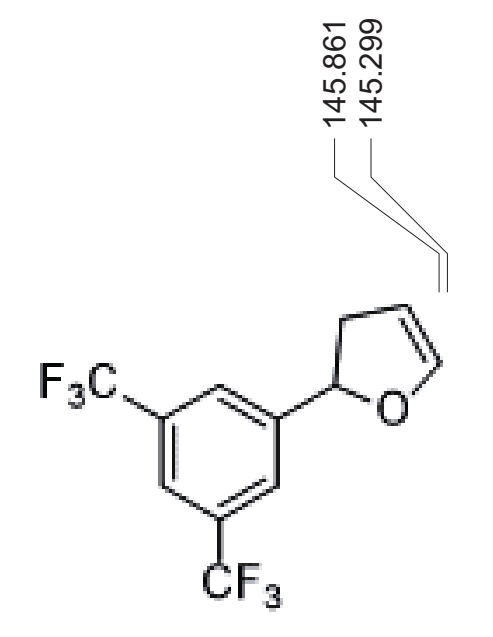

4ap $\left(100 \mathrm{MHz}, \mathrm{CDCl}_{3}\right)$

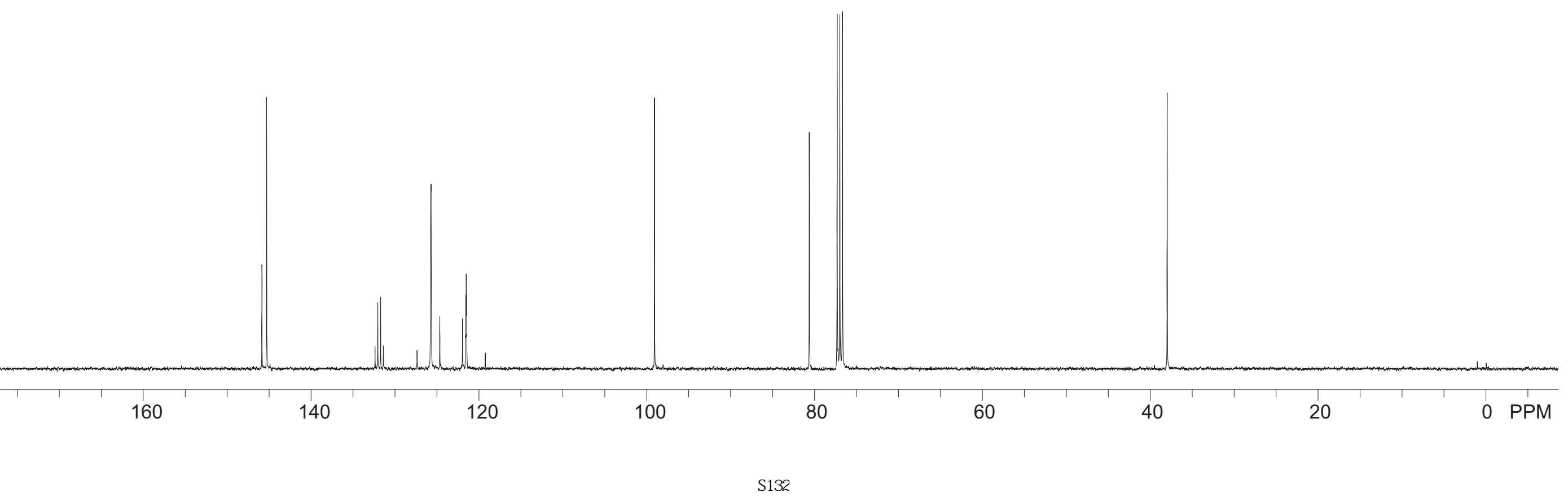




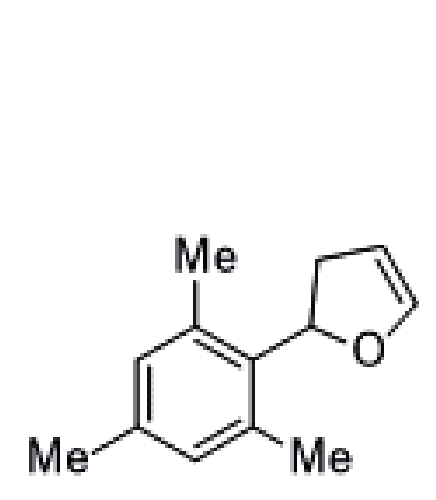

\section{4aq $\left(400 \mathrm{MHz}, \mathrm{CDCl}_{3}\right)$}




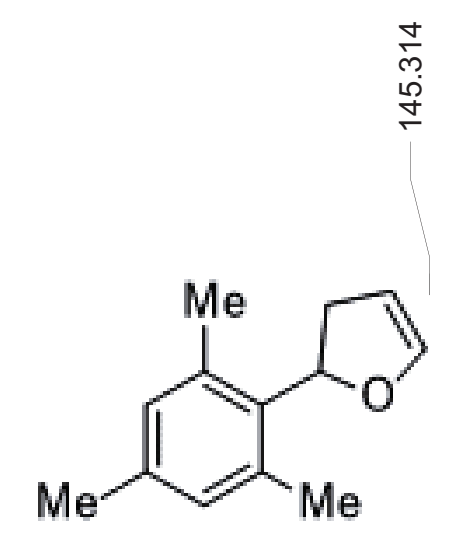

\section{4aq $\left(100 \mathrm{MHz}, \mathrm{CDCl}_{3}\right)$}

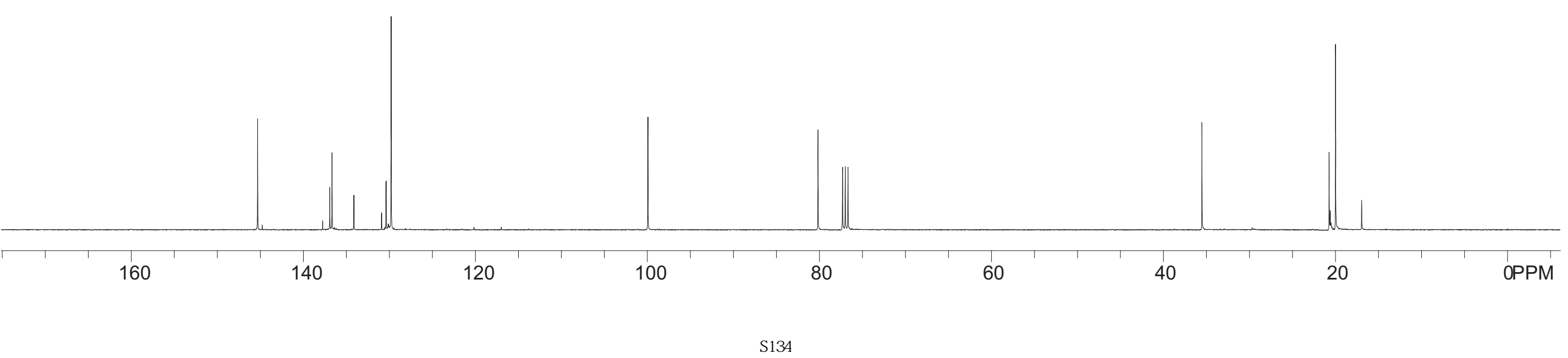


<smiles>CCOC(=O)c1c(N)cccc1C1CC=CO1</smiles>

\section{4ar $\left(500 \mathrm{MHz} \mathrm{CDCl}_{3}\right)$}

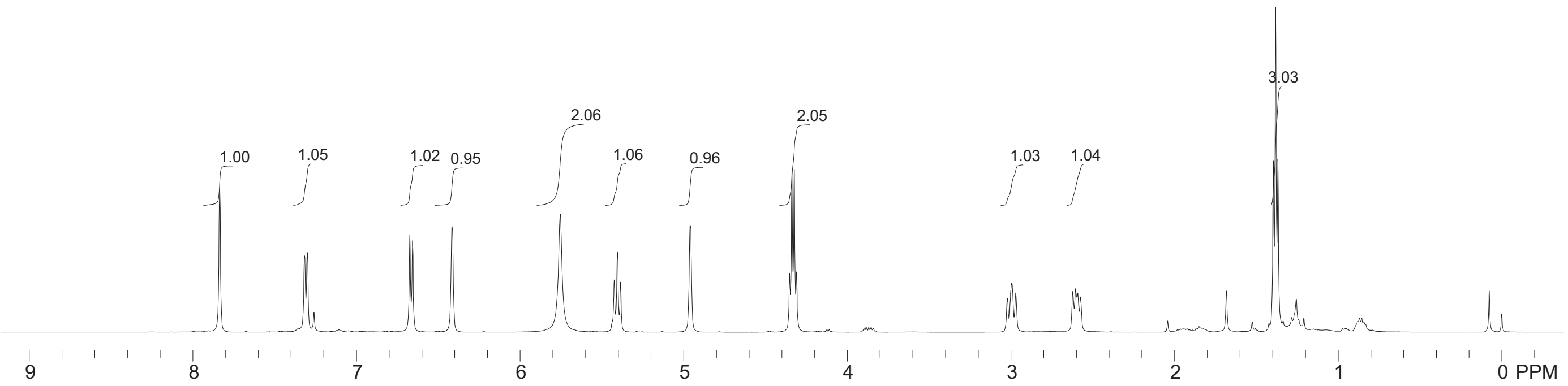



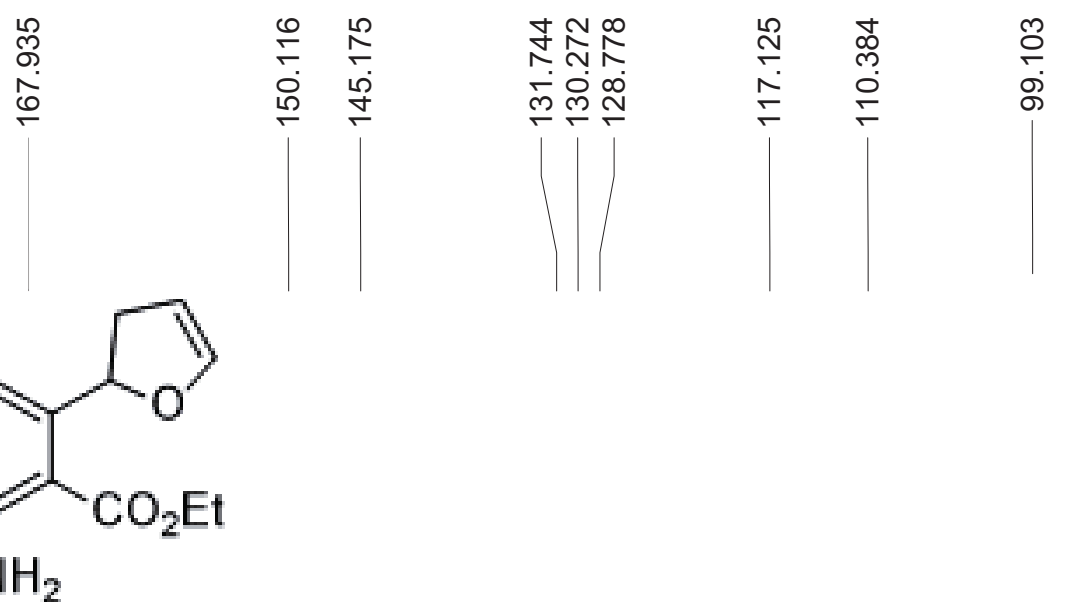

ํํำ ํㅜㅇ융ำ

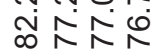

4ar $\left(100 \mathrm{MHz}, \mathrm{CDCl}_{3}\right)$

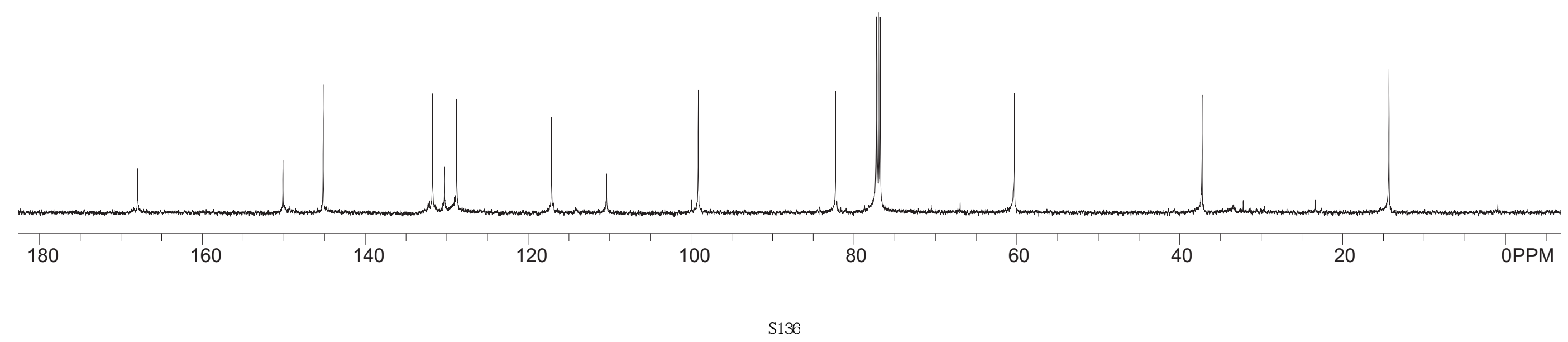


<smiles>[2H]C1=CCCO1</smiles>

D-1a

$\left(600 \mathrm{MHz}, \mathrm{CDCl}_{3}\right.$ )

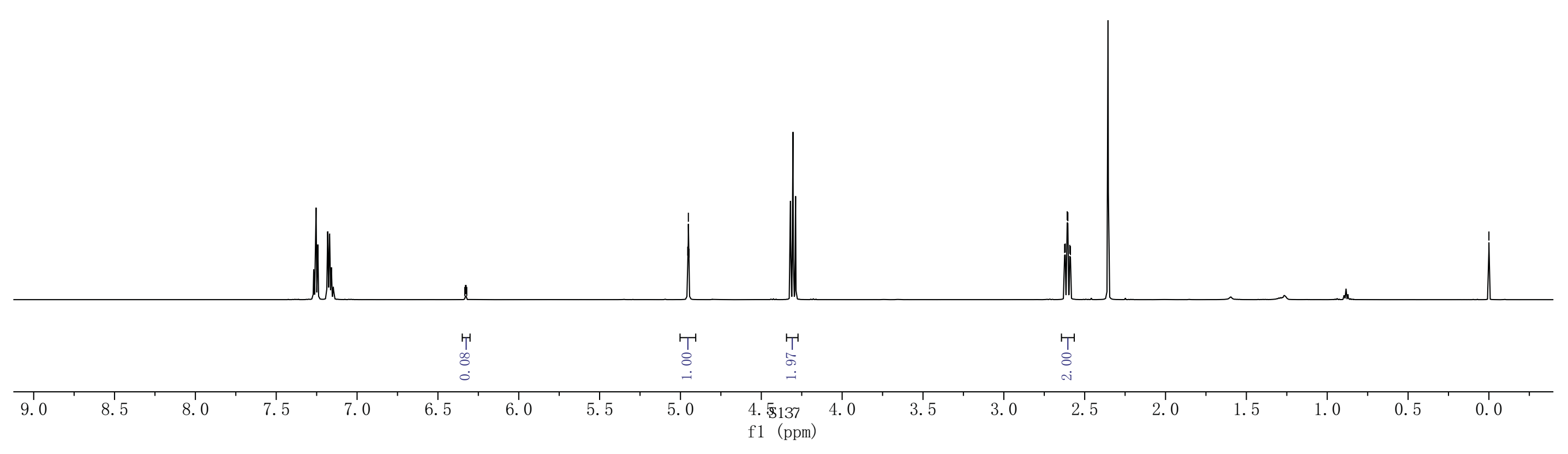




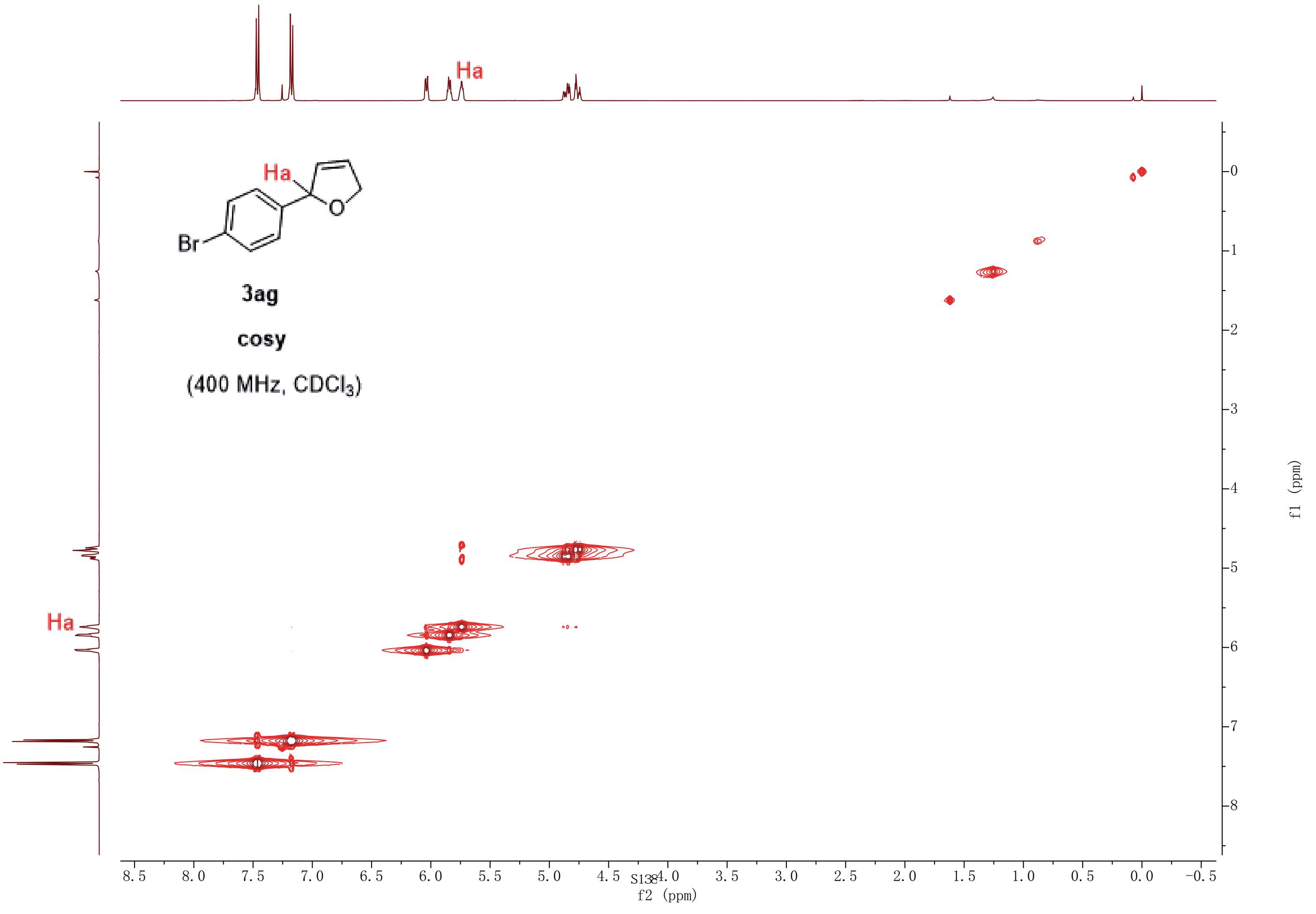




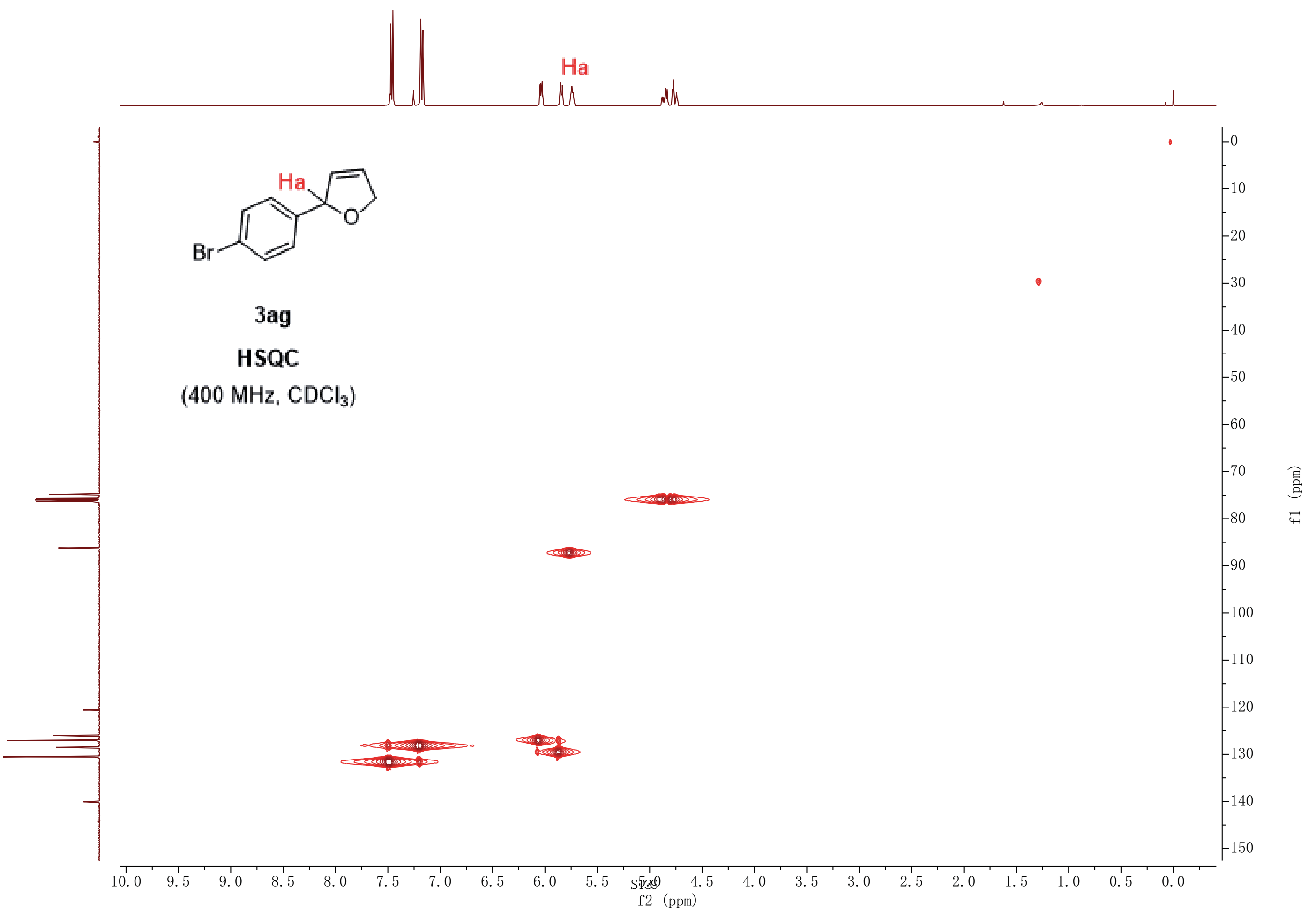




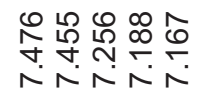

ชั

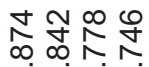

市卞并

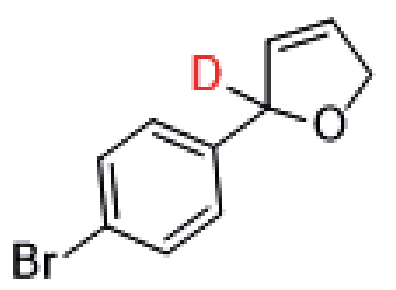

$$
\text { D-3ag }
$$

(400 MHz, $\mathrm{CDCl}_{3}$ )

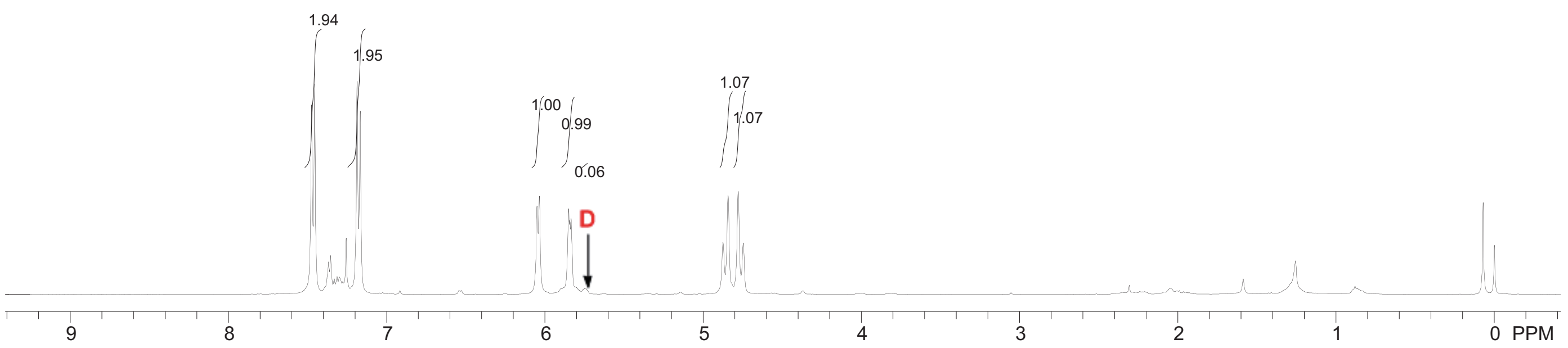




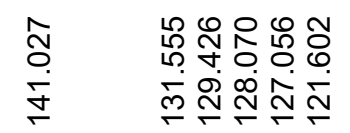

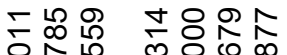

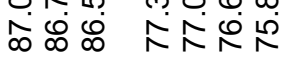<smiles>[2H]C1(c2ccc(Br)cc2)C=CCO1</smiles>

\section{D-3ag}

$\left(100 \mathrm{MHz} \mathrm{CDCl}_{3}\right)$

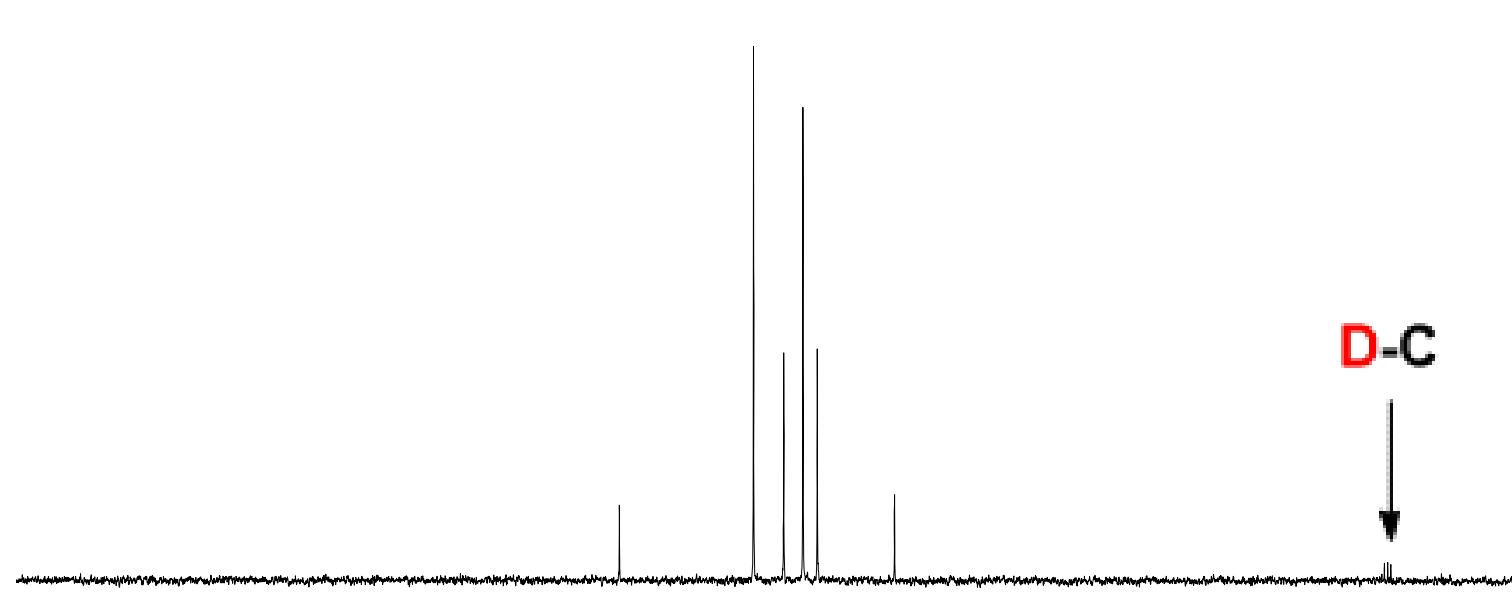




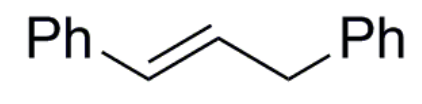

7aa

(400 MHz, $\mathrm{CDCl}_{3}$ )

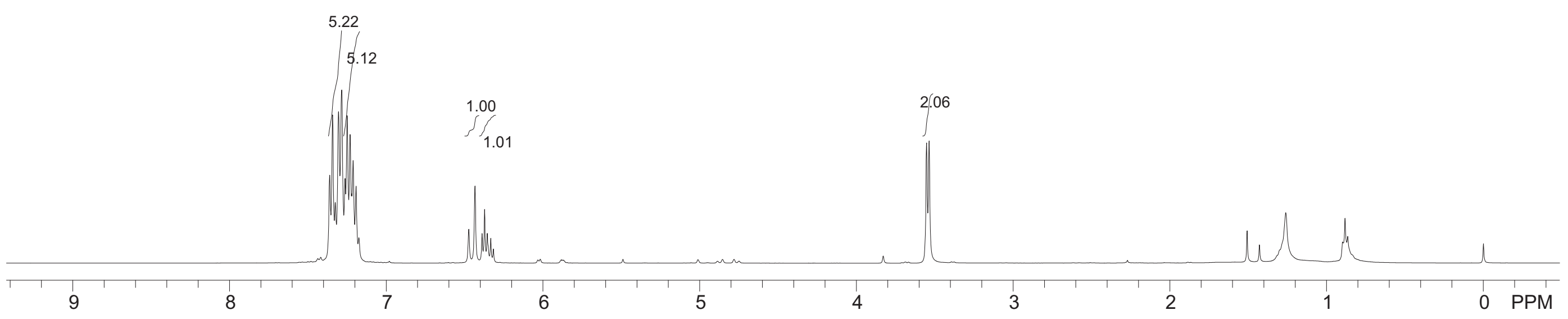




\section{$P h \simeq P h$}

\section{7aa}

(100 MHz, $\mathrm{CDCl}_{3}$ )

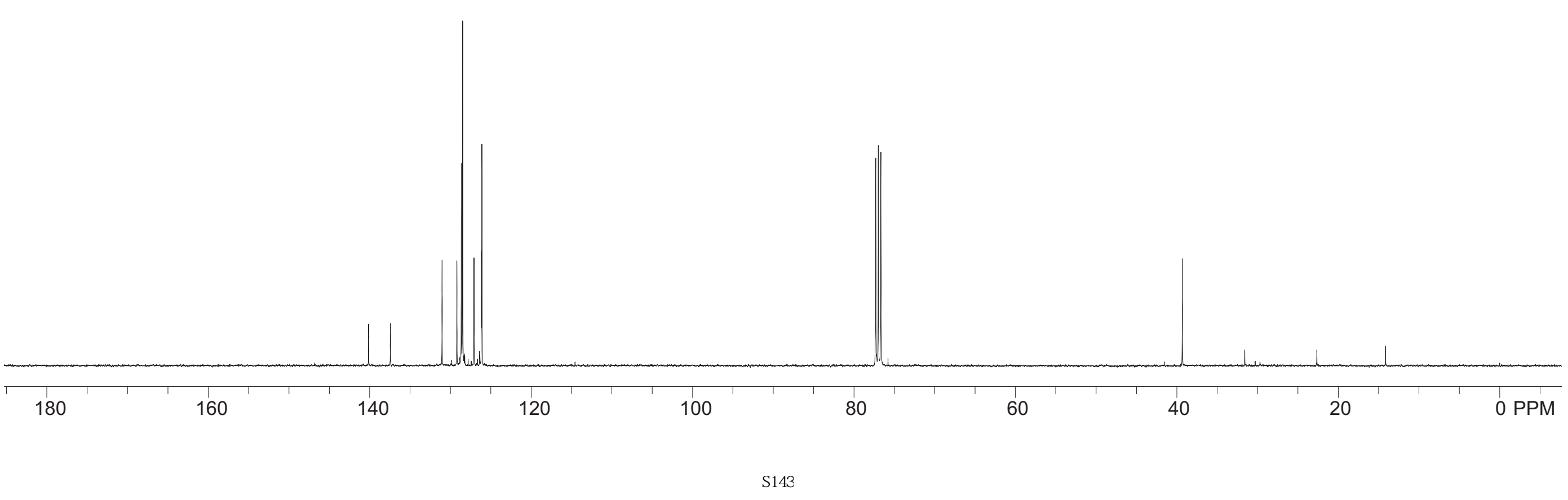


$\mathrm{Me}$<smiles>Cc1ccc(C=CCc2ccccc2)cc1</smiles>

$\mathrm{Me}$

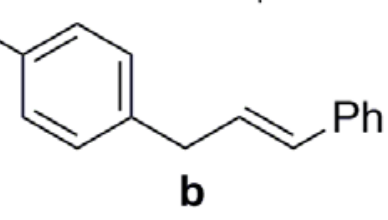

7ac $a / b=3: 1$

(400 MHz, $\mathrm{CDCl}_{3}$ )

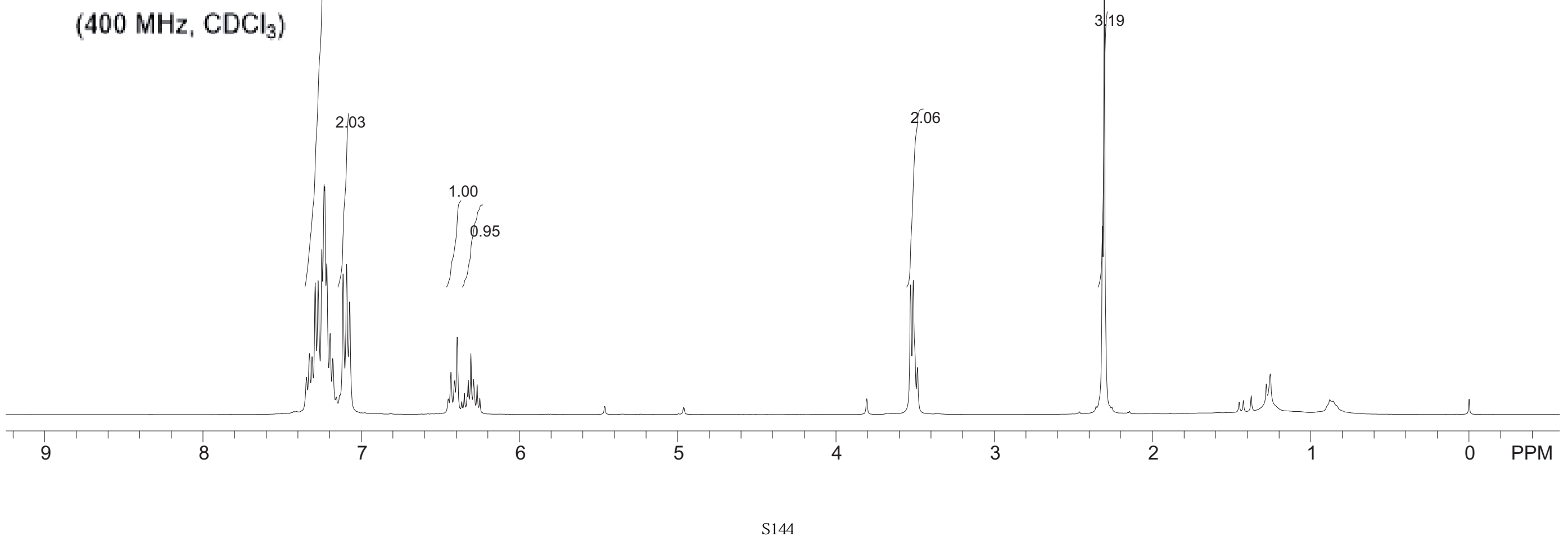


$\mathrm{Me}$<smiles>C(=C/c1ccc(Cc2ccccc2)cc1)\c1ccccc1</smiles>

a<smiles>Cc1ccc(C/C=C/c2ccccc2)cc1</smiles>

7ac $a / b=3: 1$

(100 MHz, $\mathrm{CDCl}_{3}$ )

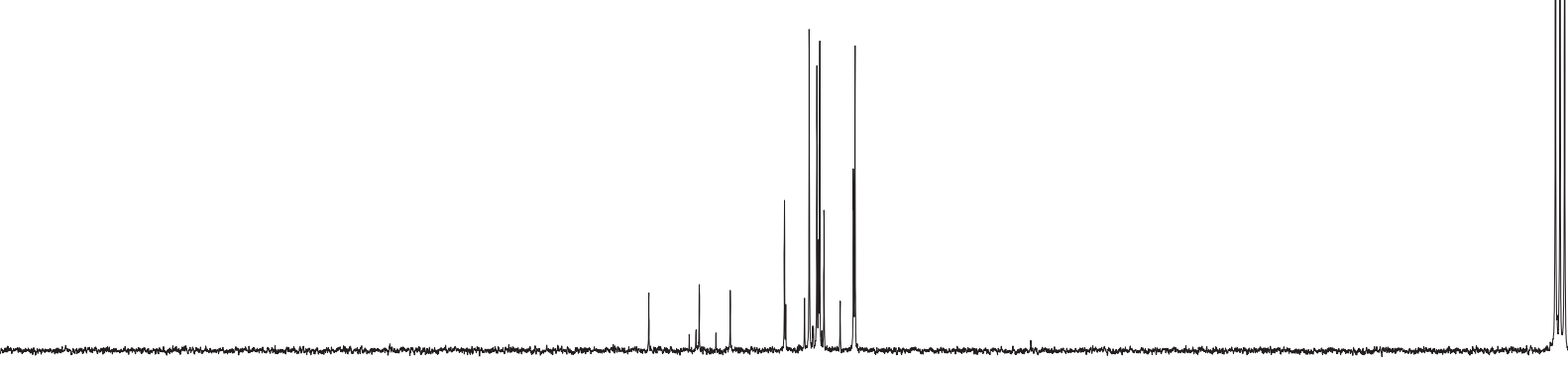

